\title{
Limnology of Oneida Lake with Emphasis on \\ Factors Contributing to Algal Blooms
}

by

Phillip E. Greeson

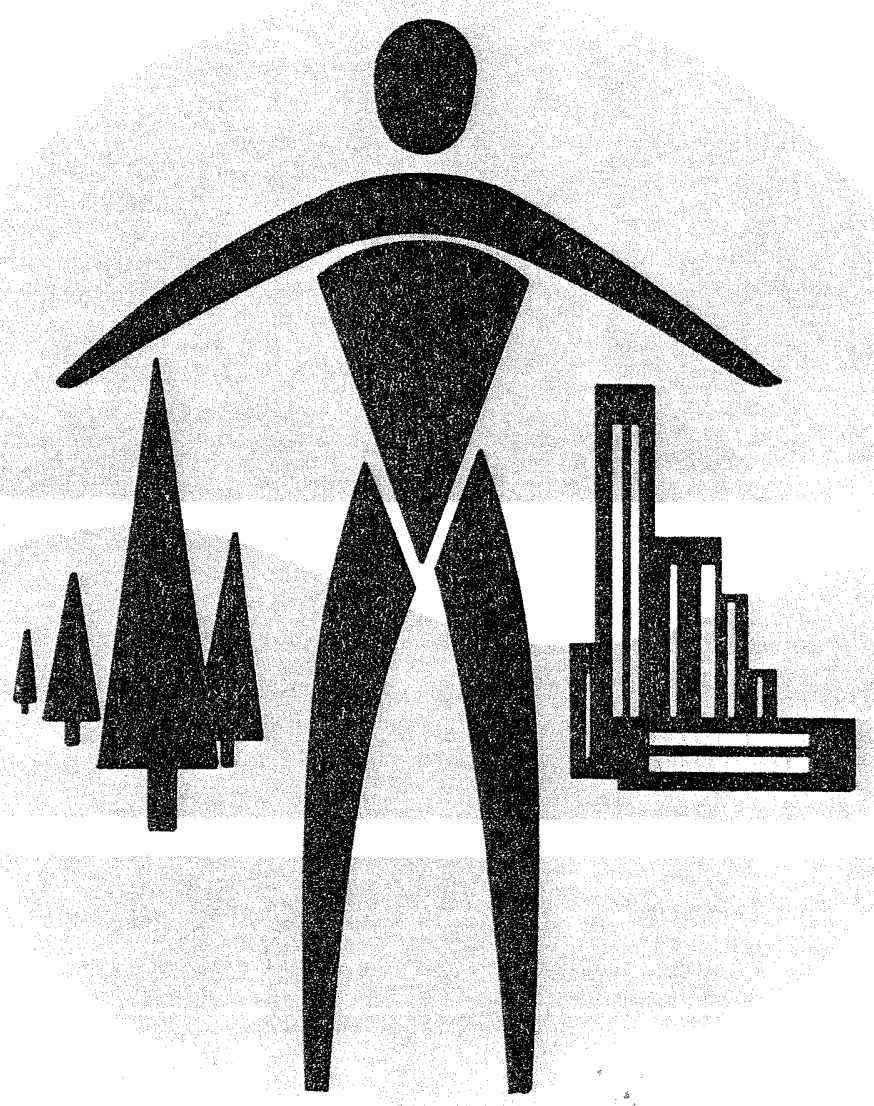

NEW YORK STATE DEPARTMENT OF ENVIRONMENTAL CONSERVATION 



\section{LIMNOLOGY OF ONEIDA LAKE WITH EMPHASIS ON \\ FACTORS CONTRIBUTING TO ALGAL BLOOMS}


"It was the grandest and most majestic sight | had seen. It was exquisitely beautiful. The sun in its full splendor at the western horizon gilding the enlightened clouds, the islands, the shores, the woods, and all seemed to vie with each other for preference. The evening was serene and delightful; a soft breeze curled the waves and fringed them with white whlle the sun, sinking toward the west beautified the whole scene."

Description of Oneida Lake by Francis Adrian Vanderkemp in 1792. 


\title{
LIMNOLOGY OF ONEIDA LAKE \\ WITH EMPHASIS ON \\ FACTORS CONTRIBUTING TO ALGAL BLOOMS
}

\author{
by \\ Phillip E. Greeson \\ U.S. Geological Survey
}

OPEN-FILE REPORT

\author{
Prepared by \\ UNITED STATES DEPARTMENT OF THE INTERIOR \\ GEOLOGICAL SURVEY \\ in cooperation with \\ NEW YORK STATE DEPARTMENT OF ENVIRONMENTAL CONSERVATION
}

Albany, New York

1971 
STATE OF NEW YORK

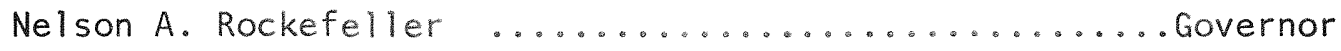

\section{Department of Environmental Conservation}

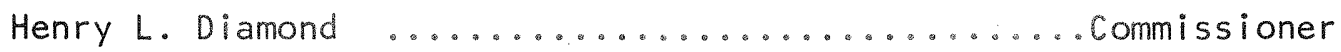

Water Management Planning Unit

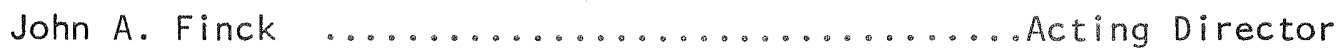

\section{UNITED STATES DEPARTMENT OF THE INTERIOR}

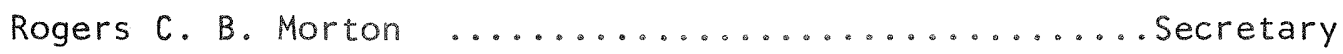

\section{Geological Survey}

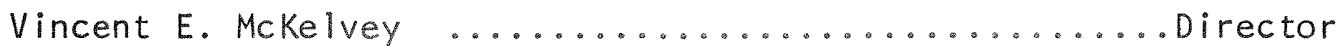

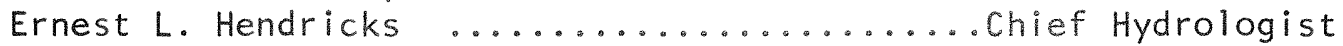

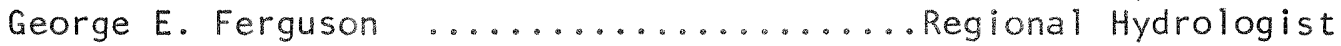

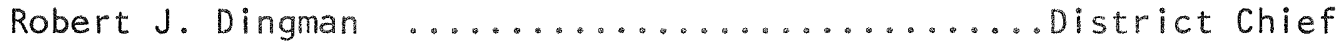




\section{CONTENTS}

Page

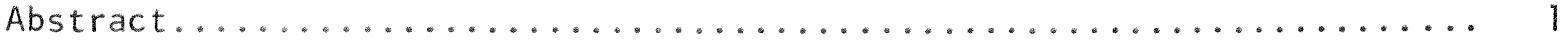

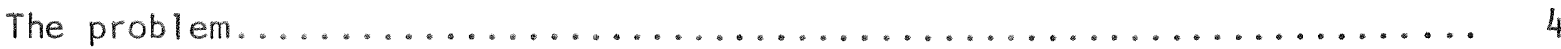

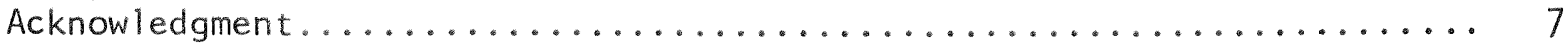

Physical and cultural factors of Oneida Lake and drainage basin...... 8

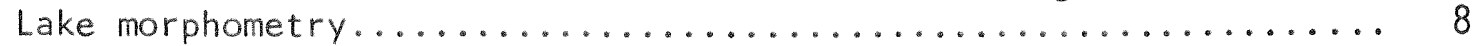

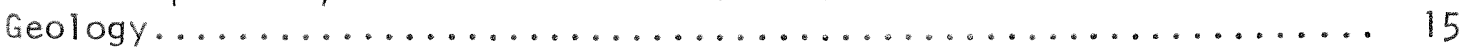

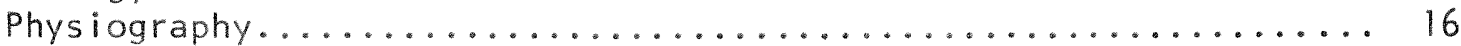

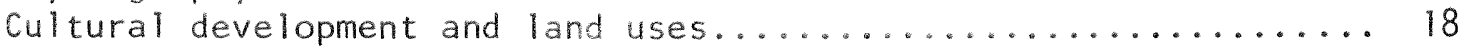

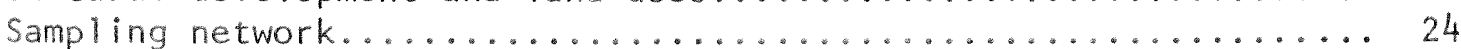

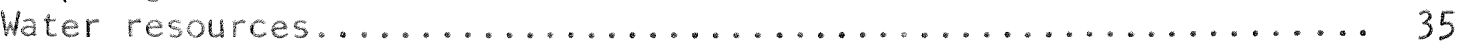

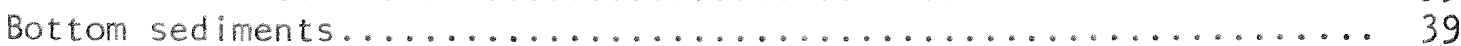

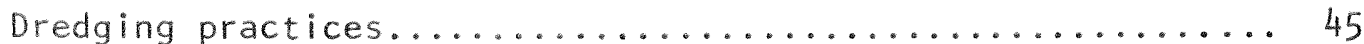

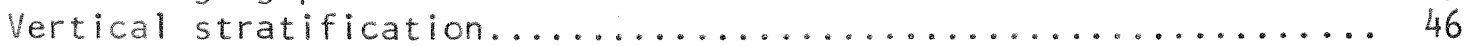

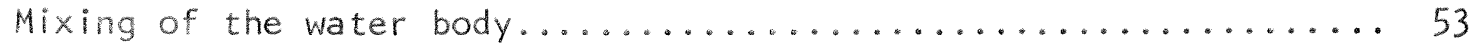

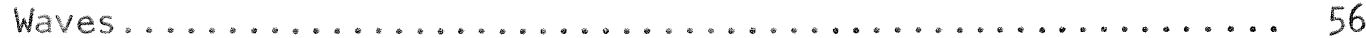

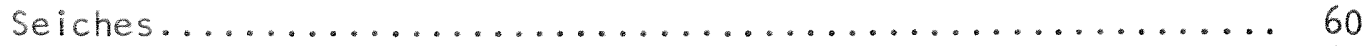

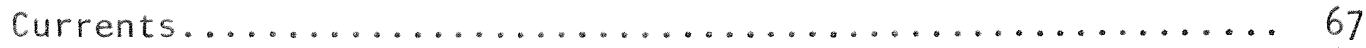

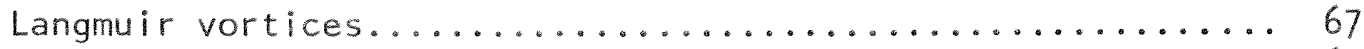

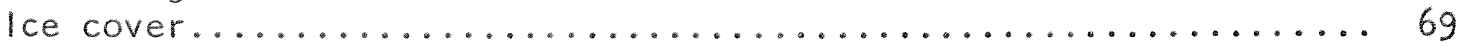

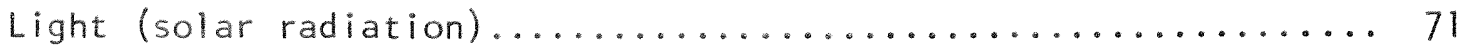

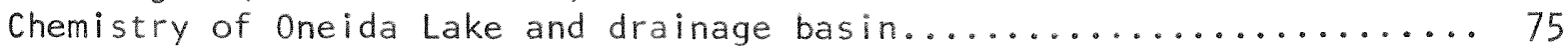

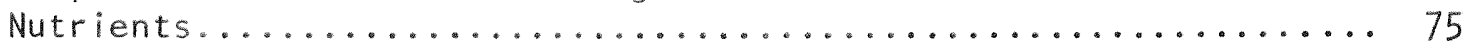

Methods of routine investigations..................... 77

Variations of the chemical constituents in Oneida Lake......... 78

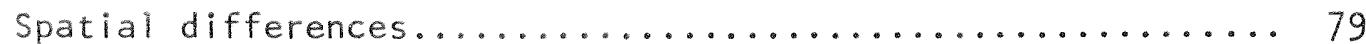

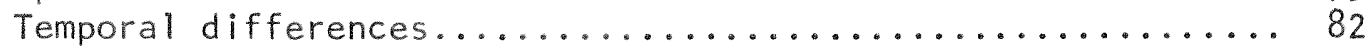

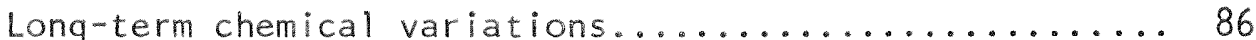

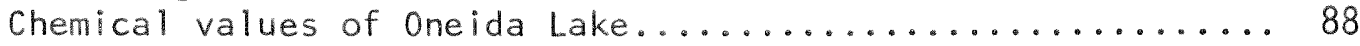

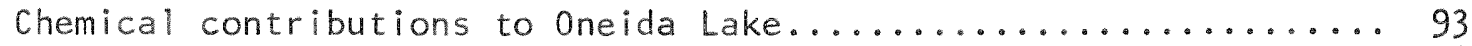

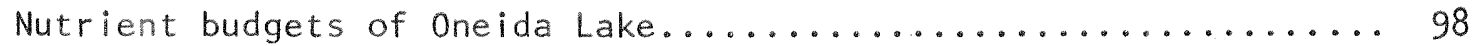

Biological characteristics of Oneida Lake................... 102

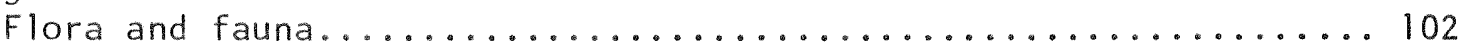

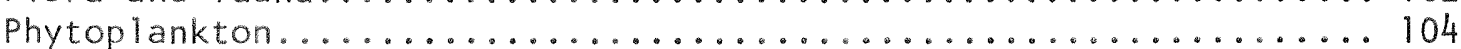

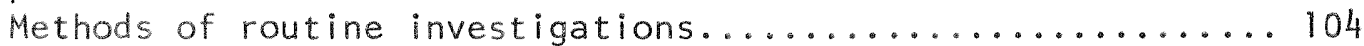

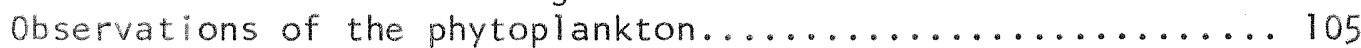

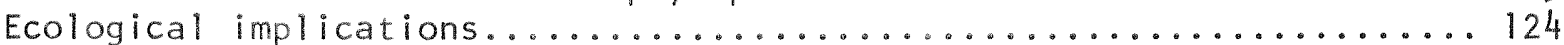

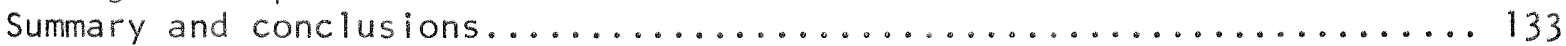

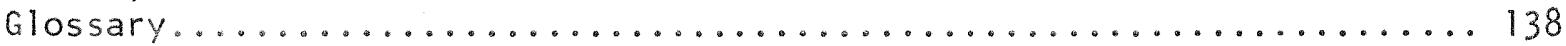

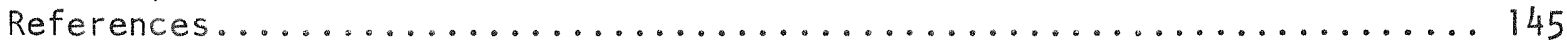

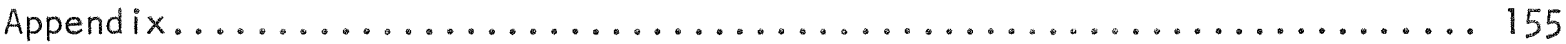




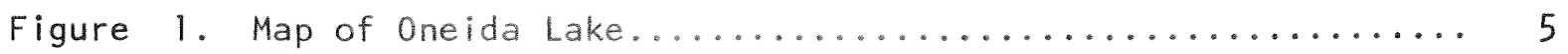

2. Sketch of eutrophication, the process of aging

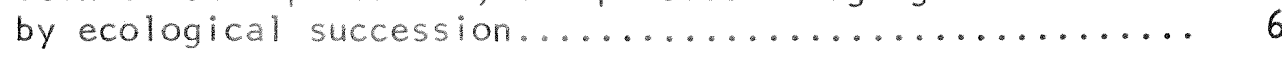

3. Graph showing area of lake bottom included at

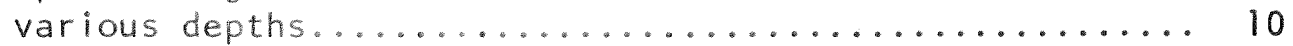

4. Map showing transects of bottom profiles............. 11

5. Diagram showing bottom profiles................. 12

6. Hydrographic map showing shoal areas of Oneida Lake. Depth of water is 14 feet or less............. 13

7. Map of Oneida Lake drainage basin................ 14

8. Map of Oneida Lake drainage basin showing five hydrochemically distinct terranes............... 17

9. Map showing location of sampling stations............ 25

10. Diagram of sampling-station location buoy............ 27

11. Map showing locations of tributaries, subbasins, and sampling stations in Oneida Lake drainage

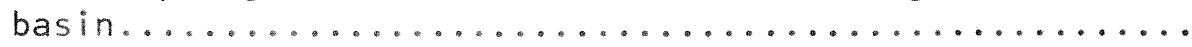

12-16. Photographs of:

12. Caughdenoy Dam on the Oneida River............... 30

13. Scriba Creek near Constantia and West Branch Fish Creek near Blossvale................... 31

14. East Branch Fish Creek at Taberg and Wood Creek near New London......................... 32

15. Oneida Creek at Oneida Valley and Canaseraga Creek near Lakeport....................... 33

16. Cowaselon Creek at Oniontown and Chittenango

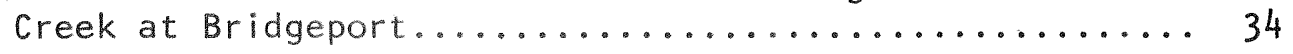

17. Map with lines indicating mean annual precipitation for Oneida Lake drainage basin, 1931-60.......... 36

18. Diagram illustrating water budget of Oneida Lake........ 39 


\section{ILLUSTRATIONS (Continued)}

Page

Figure 19. Aerial photograph showing the development of sandy beaches in the southeastern part of Oneida Lake........ 40

20. Photographs showing collection of bottom samples from Oneida Lake with Peterson dredge and piston corer................................. 42

21. Map showing areal distribution of bottom materials in Oneida Lake.................... 43

22. Sketch showing seasonal temperature variations in a temperate lake and generalized thermal stratification during the summer season............ 46

23. Vertical profiles of water temperature and dissolved-oxygen content during the growing

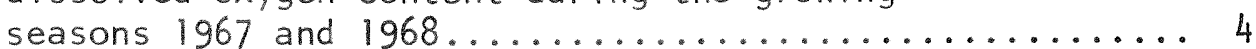

24. Diagram showing vertical profile of water temperature under ice cover.................... 49

25. Graphs showing mean depth of dissolved-oxygen stratification during the growing seasons

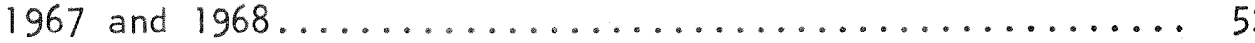

26. Wind roses for calendar years 1967 and 1968, Hancock Field, Syracuse, New York, showing percentage of time that wind was recorded from each direction.......................... 54

27. Wind roses for growing seasons, June through September 1967-69, Hancock Field, Syracuse, New York, showing percentage of time that wind was recorded from each direction............. 55

28. Sketch illustrating wave of oscillation and circular pattern of water movement in deep water....... 56

29. Graph showing development of waves on Oneida Lake........ 57

30. Hydrographic map showing areas of Oneida Lake where

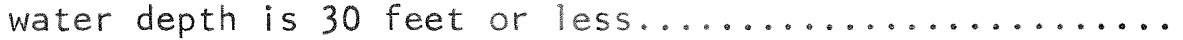

31. Sketch illustrating fluctuation of the water surface in a uninodal seiche...................66 61

32-36. Graphs showing:

32. Harmonic train of seiches, September 23-26, 1966........ 


\section{ILLUSTRATIONS (Continued)}

Page

Figure 33. Development and extinction of a seiche,

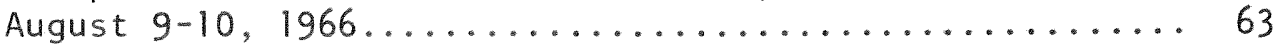

34. Development of seiche, August 16-17, 1966.......... 64

35. Development of seiche in Oneida Lake, July 30-

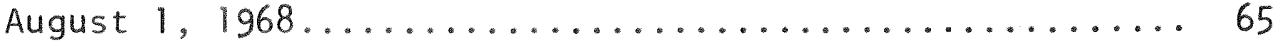

36. Development of seiches in Oneida Lake, August 10-

11,1968 , and September $27-28,1968 \ldots \ldots \ldots \ldots 6 . \ldots 66 . \ldots . \ldots 6$

37. Aerial photograph showing wind streaks on Oneida Lake, September 23, 1967.....................68

38. Map showing generalized location of water masses under ice cover, late March................... 70

39-43. Graphs showing:

39. Duration of daylight and amount of sunlight, May

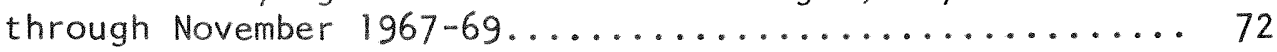

40. Light penetration in Oneida Lake, October 1, 1969........ 74

41. Spatial variations of dissolved-solids content of Oneida Lake, May 1967 through August 1968........... 81

42. Mean monthly values for various biological, chemical, and physical parameters, Oneida Lake, June 1967

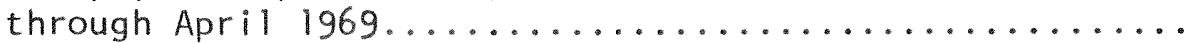

43. Mean monthly concentration of selected chemical constituents, Oneida Lake, June 1967 through April 1969.

44. Diagram illustrating chemical budget of dissolved solids in Oneida Lake...................... 98

45. Photographs of representative blue-green algae from Oneida Lake.......................... 113

46. Photographs of representative phytoplankton

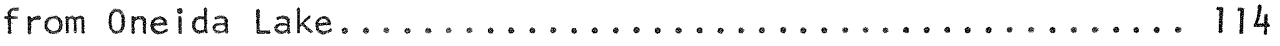

47. Graphs showing relative abundances of the major groups of algae composing the phytoplankton of One ida Lake. 


\section{ILLUSTRATIONS (Continued)}

Figure 48. Graphs showing spatial variations of phytoplankton during the growing seasons 1967 and $1968 \ldots \ldots \ldots \ldots 121$

49. Graph showing variations of phytoplankton in eastern

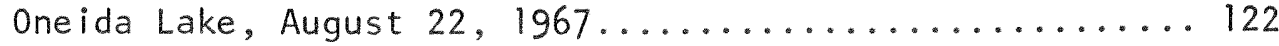

50. Photograph of decomposing algal mats near Bushnell

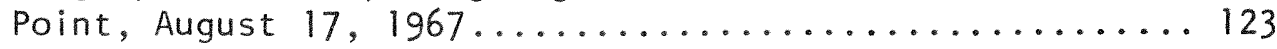

51. Hypothetical curve of eutrophication............... 125 
TABLES

Page

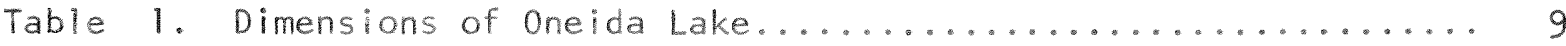

2. Relative sizes of subbasins in Oneida Lake drainage basin and areas of contributing terranes..............

3. Development of shoreline of Oneida Lake between

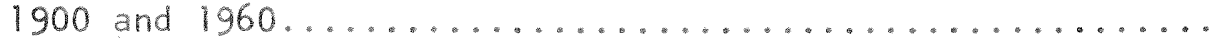

4. Percentage land uses of the Oneida Lake drainage basin.....

5. Approximate locations of sampling stations on Oneida Lake... 26

6. Locations of sampling stations in Oneida Lake drainage

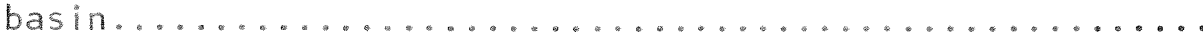

7. Precipitation and discharge for the subbasins in the

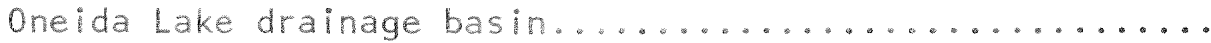

8. Composition of bottom materlals at selected locations

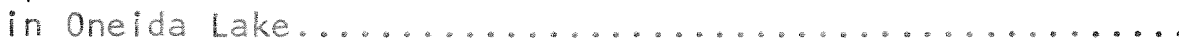

9. Vertical profiles of water temperature and dissolved

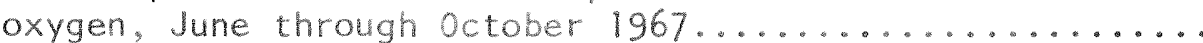

10. Vertical profiles of water temperature and dissolved oxygen, June through october 1968............... 51

11. Secchi disc transparencies in Oneida Lake during the

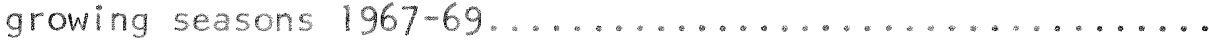

12. Elements essential to the production of algae........... 76

13. Mean, maximum, and minimum values of physical properties, chemical constituents, and phytoplankton at ea $h$ sampling station on Oneida Lake, May 1967 through

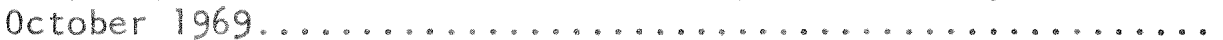

14. Mean values of physical properties and mean concentrations of major chemical consticuents at 10-foot depth intervals during periods of dissolved-oxygen stratification and

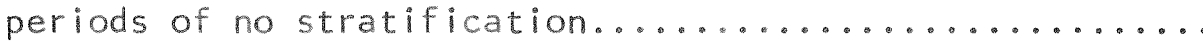

15. Long-term mean variations of selected chemical constituents and properties of Oneida Lake.............

16. Concentrations of trace metals in Oneida Lake............ 90

17. Pesticide concentrations in samples from Oneida Lake on October 1, 1969. 


\section{TABLES (Continued)}

Page

Table 18. Mean water temperature, specific conductance, pH, and concentrations of dissolved chemical constituents in Oneida Lake, May 1967 to

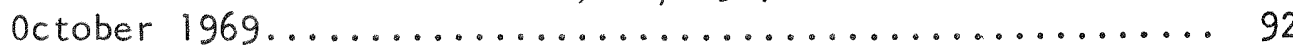

19. Mean annual loads of selected chemical constituents in the large tributaries to Oneida Lake................ 94

20. Concentrations of trace metals in the tributaries

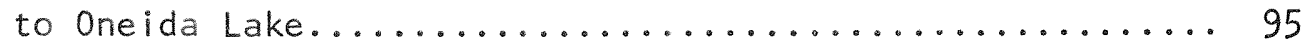

21. Cultural contributions of nitrogen and phosphate

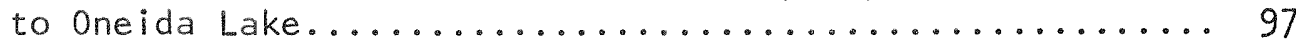

22. Chemical budgets of the major nutrients in Oneida Lake..... 99

23. Composite list of algae observed in phytoplankton of

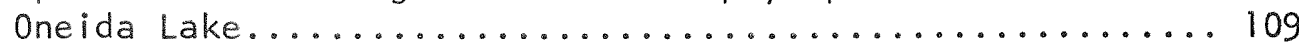

24. Other algae recently reported in the phytoplankton of Oneida Lake............................... 112

25. Distribution of algae observed two or more times in the phytoplankton of Oneida Lake............... 116

26. Dominant phytoplankton organisms in Oneida Lake......... 117

27. Summary of water budgets, dissolved-solids contents and algal blooms in Oneida Lake, May 1967 through

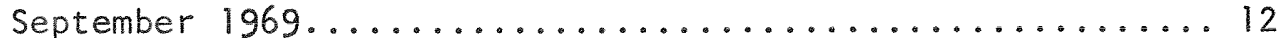

28. Predicted water budget of Oneida Lake after diversion

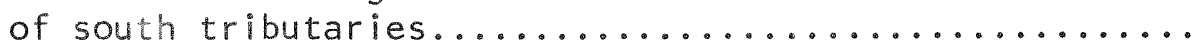

29. Predicted annual chemical budget of dissolved solids in Oneida Lake after diversion of south tributaries...... 131

30. Field measurements and chemical analyses of samples collected routinely from stations in the Oneida

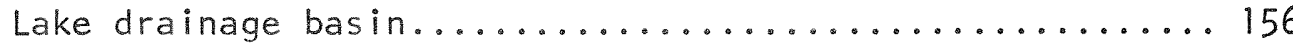

31. Field measurements and chemical analyses of surface samples collected routinely from stations on Oneida Lake................................... 161

32. Checklist of the flora and the fauna of Oneida Lake including algae, fish, macroinvertebrates, vascular plants, and zooplankton. 



\section{LIMNOLOGY OF ONEIDA LAKE \\ WITH EMPHASIS ON}

FACTORS CONTRIBUTING TO ALGAL BLOOMS

by

Phillip E. Greeson

\section{ABSTRACT}

Oneida Lake is a naturally eutrophic lake that has existed for about 10,500 years. It has been in a eutrophic state for at least 350 years, and the geochemically derived dissolved materials entering the lake from the drainage basin are of sufficient quantity $(449,700$ tons per year) to support annual algal blooms. The greatest amount of the dissolved materials (72 percent) comes from the southern tributaries to the lake, of which Chittenango Creek carries the largest load of almost all major chemical substances. The stream contributes 37 percent of all dissolved solids entering the lake. Ground water is negligible in both the water and the nutrient budgets.

Oneida Lake retains 50,000 tons of dissolved solids each year. These materials become incorporated in the bottom sediments. About 89 percent of all dissolved solids entering the lake leave the lake by the oneida River.

Water in Oneida Lake represents a hydrologic equilibrium. Water entering the lake is from direct precipitation (149,600 acre-feet per year) and from surface water inflow $(1,729,000$ acre-feet per year). Water leaves the lake by outflow through the Oneida River (1,730,400 acre-feet per year) and by evaporation (148,200 acre-feet per year). Sixty-seven percent of all water entering Oneida Lake originates in the northern part of the drainage basin.

Quality of the lake water depends on the quality of inflowing water. Quantity of dissolved nutrients in the lake fluctuates seasonally with changes in the amount of surface water inflow and annually with changes in the annual water budget. On any ice-free day, the dissolved nutrients in the lake are virtually uniform in concentration, both vertically and areally. Slightly higher concentrations in the western and the southern parts of the lake result from the inflow of highly mineralized water from the southern tributaries.

Uniform concentrations of dissolved nutrients result from several mixing processes, the most important of which is wind-generated wave action. Prevailing westerly winds create a maximum wave height exceeding. 6 feet on Oneida Lake. Effective mixing occurs to a depth of about 30 feet, a depth where a sharp dissolved-oxygen stratification develops during the growing season of the phytoplankton. The stratification is not accompanied by thermal variations. 
Because the lake is shallow (the average depth is only 22 feet), bottom materials on 65 percent of the lake bottom can be subjected to mixing with the overlying water. On the basis of composition and size, the bottom materials of Oneida Lake can be divided into five types. The types and their percentage distribution on the lake bottom are cobble and rubble, 10.2 percent; gravel, 4.2 percent; sand, 17.8 percent; silt and clay, 40.3 percent; and mud (silt, clay, and organic matter), 27.5 percent. Distribution of bottom materials has not changed significantly in the past 60 years.

Additional water mixing occurs by seiches and currents. A typical seiche in the lake is uninodal and extends along the long axis of the lake. The vertical displacement of water may exceed 1.6 feet during a period of about 2.4 hours. Surface currents in the lake are usually in the direction of the prevailing winds, and greatest current velocities are associated with sustained moderate winds of about $5-10$ miles per hour. Deep water currents generally flow opposite the direction of the winds.

of the elements, ions, and compounds studied, none appears to be a limiting factor on the bodily processes of algae or on the extent of bloom formation. Bloom-essential nutrients in Oneida Lake reached critical minimal concentrations many years ago and, subsequently, have increased in concentration. Concentrations of nutrients in the lake today are more than adequate for the healthy existence of phytoplankton, even during large algal blooms. Nitrogen and phosphorus never approached growth-limiting concentrations. Dissolved-solids content of the lake water seems to be an index of growth conditions in the lake because it integrates the total nutritional complex with the interactions of environmental factors.

Observed biological changes in Oneida Lake in the past 50 years are not dramatic. Of the 117 species of algae observed in the phytoplankton, 42 can be considered common or abundant. The four species of blue-green algae that characterize Oneida Lake are Anabaena flos-aquae, Aphanizomenon holsaticum, Microcystis aemginosa, and Anabaena circinalis. Other abundant blue-green algae include Anabaena spiroides, Gloeotrichia echinulata, Microcystis incerta, Lyngbya Birgei, and Oscillatoria subbrevis.

Phytoplankton populations (sometimes approaching 1 million cells per milliliter) are seldom uniform over the entire lake. Heavy concentrations in bay areas and localized blooms are common. Heavy algal concentrations along the shore and decaying heaps of algae on the shore usually result from wind-swept drifts of algal mats from the open lake.

The four most important factors affecting the ecological processes in Oneida Lake are: (1) high fertility of the drainage basin, (2) physical position and shallowness of the lake, (3) mixing as caused by wind, and (4) fertility of the bottom sediments. The hydrologic regime of oneida Lake and its drainage basin is a principal factor in the production of algae. Drought years and years in which the contribution of water from the southern tributaries is larger than usual can be associated with nuisance algal conditions in the lake.

A reduction in quantity of inflowing nutrients to Oneida Lake would reduce the nutrient content in the lake and would decrease the potential 
for biological production. The amount of inflowing naturally derived nutrients could be decreased by diverting the southern tributaries around or away from the lake.

Diversion of the southern tributaries would have no effect on many of the physical processes in the lake. The most pronounced changes would occur in the annual water budget and in the concentrations of chemical substances. Enough water to maintain the hydrologic equilibrium enters Oneida Lake from its northern tributaries. Diversion of the southern tributaries would probably reduce the average dissolved-solids content in the lake from 163 to about 70 milligrams per liter. Diversion would al so remove the greatest amount of artificial enrichment that the lake is receiving and would have minimal effect on the dynamics of the downstream Oneida River. 



\section{THE PROBLEM}

Oneida Lake, with a surface area of 79.8 square miles (206.7 square kilometers), is the largest lake wholly within New York state (fig. 1). It is used almost exclusively for recreation, but it also serves as an important link in the New York State Barge Canal System. During the summer, Oneida Lake exhibits a tremendous growth of planktonic blue-green algae. (See Glossary.) Production of these organisms is so great that the recreational uses of the lake are hindered, and the decomposition of algae along the shore becomes esthetically unpleasant for lakeside residents.

The problem in Oneida Lake is a result of eutrophication, the inevitable natural aging process affecting every body of water. Figure 2 shows that lake eutrophication consists of the gradual progression (termed "ecological succession") from one life stage into another. In the youngest stage of the life cycle, a lake is called an oligotrophic lake and is characterized by cold, unproductive water. Nutrients accumulate and algal production increases; at some point the lake becomes mesotrophic and later eutrophic, or highly productive.

The final life stage before the climax extinction is a pond, marsh, or swamp. The extinction of a lake is a result of enrichment, productivity, decay, and sedimentation (Greeson, 1969).

As a lake passes through each stage of life, enrichment by nutritive materials increases. In general, a lake will serve as a trap for part of the nutrients originating in the surrounding drainage basin and entering through streams, precipitation, and ground-water inflow. Some of the entrapped nutrients are recycled by the aquatic vegetation during each growing season.

A eutrophic lake, such as Oneida Lake, is distinguished by a high content of dissolved nutrients and an abundance of aquatic organisms. Plants, particularly the planktonic blue-green algae, are of first concern because they utilize the dissolved inorganic salts (nutrients) directly from the water. If all other factors are favorable, blue-green algae grow to bloom proportions, which adversely affect man's use of the water body.

Oneida Lake has been eutrophic for at least 350 years, and possibly it has been eutrophic from its formation. In the early $1600^{\prime}$ s, Samuel D. Champlain, believed to be the first white man to see onelda Lake, described its condition as being what is now known as eutrophic. In 1809, James Fenimore Cooper described the lake as, "a broad, dark colored body of water, unwholesome to drink and strongly blended with dark particles which the boatmen called lake blossoms" (New York State Conservation Department, 1947). Similar "lake blossoms" are in evidence today (1971) in Oneida Lake.

Although control measures for excessive algal growths are practiced in certain lakes, the size of oneida lake prohibics practical and economic justification for any of the known measures. Furthemore, present measures of algal control are generally orlented to the direct elimination of algae; that is, toward the effect rather than the cause of the problem. Such methods are only of temporary effectiveness. 


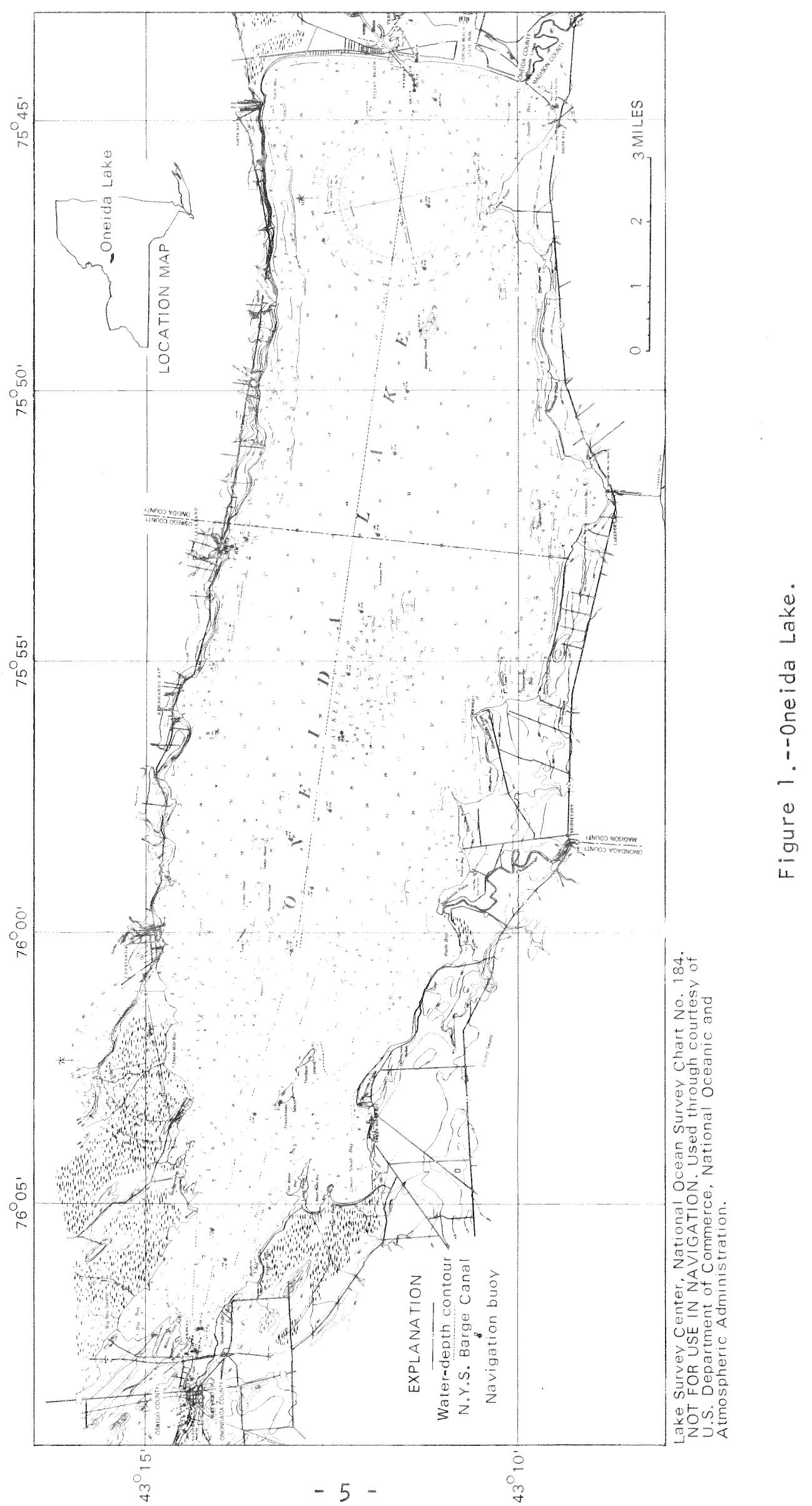




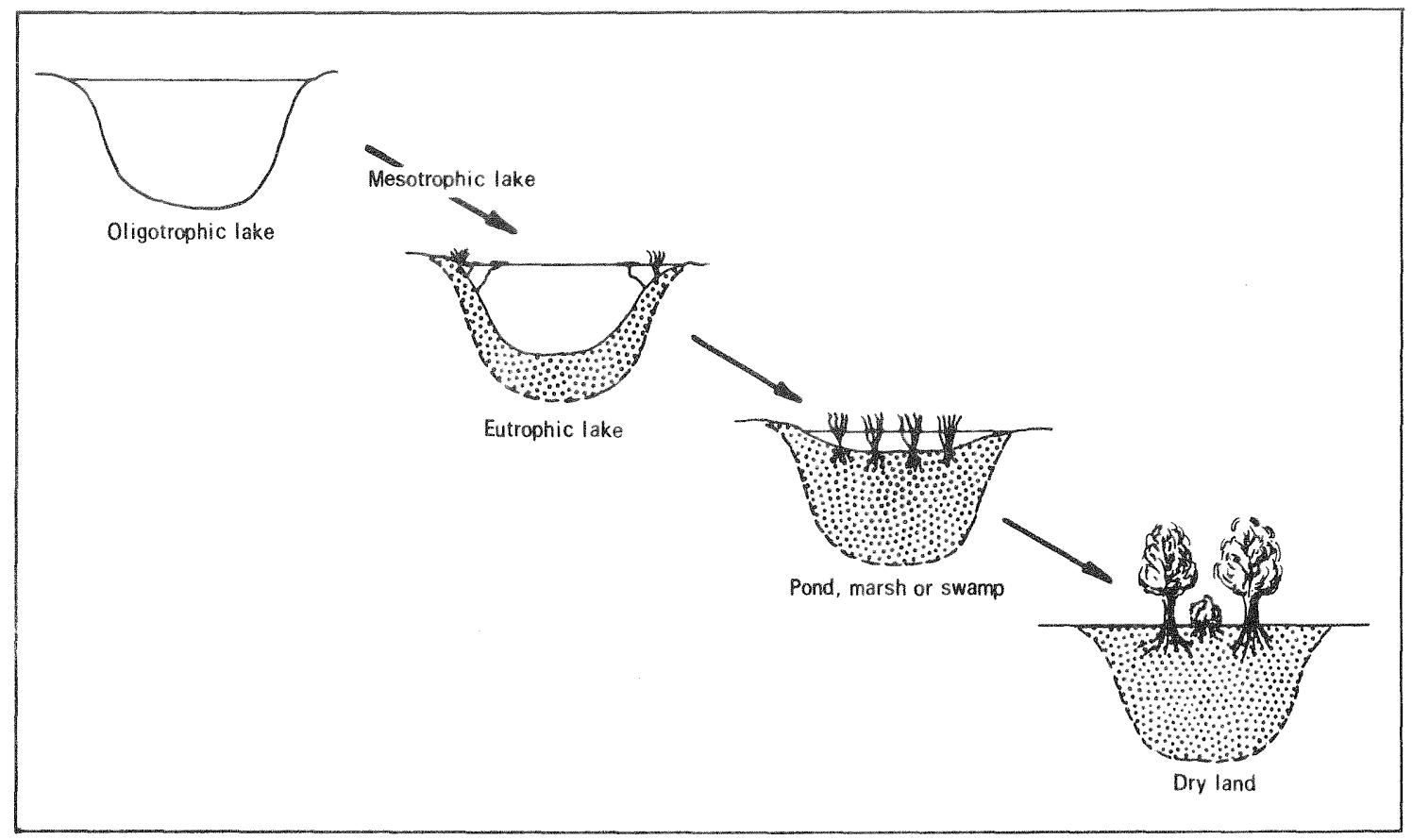

Figure 2.--Eutrophication, the process of aging by ecological succession (from Greeson, 1969).

In April 1967, the U.S. Geological Survey, in cooperation with the New York State Department of Environmental Conservation, began a comprehensive program to study the eutrophication of Oneida Lake. In essence, the program objectives were to define the cause and effect relationships contributing to algal production in the lake and to provide the necessary information for controlling the algal blooms.

Basis of the study was the determination of water, mineral, and organic nutrient balances of the entire lake system, including contributions from streamflow, precipitation, ground-water inflow, and cultural activities. The study also included (1) physical and chemical descriptions of Oneida Lake and its drainage basin, (2) description of type and quantity of organisms present, (3) analysis of chemical and physical conditions of the lake system, which appeared to cause or be associated with the various biological changes within the lake, and (4) evaluation of algal control methods and their applicability to the problems in Oneida Lake. Several reports (Greeson and Meyers, 1969; Pearson and Meyers, in press) based on these investigations have been completed.

This final report of the study, including description and discussion of the limnology of Oneida Lake and its basin, emphasizes factors contributing to the annual nuisance algal blooms in the lake. 

The author gratefully acknowledges the assistance of many persons during various phases of the study. Special appreciation is extended to Dr. John L. Forney, Cornell University Biological Field Station; Mr. Charles C. Knapp, Bridgeport, New York; and Mr. Millard Rogers, Brewerton, New York. The encouragements offered during the study by the local residents at Oneida Lake and by members of the Oneida Lake Association were sincerely appreciated.

This report was prepared under the direction of Robert J. Dingman, district chief, and under the supervision of Kenneth 1. Darmer, chief, hydrologic studies section of the New York district, U.S. Geological Survey. 

PHYSICAL AND CULTURAL FACTORS OF ONEIDA LAKE AND DRAINAGE BASIN

\section{Lake Morphometry}

Oneida Lake, the largest lake wholly in New York State, lies about 11 miles north of Syracuse in Oneida and 0swego counties. The lake is regulated by a tainter-gate dam, Caughdenoy Dam (fig. 12), constructed in 1910 on the Oneida River at Caughdenoy, 1.6 miles ( 2.6 kilometers) downstream from Brewerton, the mouth of the lake. The lake drains to the west through the Oneida and the Oswego Rivers into Lake Ontario at Oswego.

The main axis of the lake is 20.9 miles ( 33.6 kilometers) in length (table 1) and extends from the State Highway 13 bridge at Sylvan Beach on the east to the U.S. Highway 11 bridge in Brewerton on the west. Maximum width is 5.5 miles $(8.8$ kilometers) and average width is 3.8 miles $(6.1$ kilometers).

Oneida Lake has a surface area of 79.8 square miles (206.7 square kilometers) at the normal summer stage of 369 feet $(112$ meters) above mean sea level. Thirty-four streams drain into the lake, but only eight of these carry significant quantities of water. They are Scriba, East Branch Fish, West Branch Fish, and Wood Creeks from the north and Oneida, Canaseraga, Cowaselon, and Chittenango Creeks from the south.

The shore of the lake is uniformly low, sandy, and, in places, wooded and swampy. On the north shore are the villages of Constantia, Bernhards Bay, Cleveland, and North Bay. The villages of Bridgeport and Lakeport are on the south shore. Sylvan Beach and Verona Beach are on the east shore. The shoreline, which extends for $54.7 \mathrm{miles}(88.0 \mathrm{killometers),} \mathrm{is} \mathrm{dotted}$ with summer cottages and fishing camps.

Oneida Lake is shallow, with an average depth of 22.3 feet $(6.8$ meters) and a maximum depth of 55 feet (16.8 meters) near the north shore off cleveland. The development of volume $\left(d_{v}\right)$ or the index of bottom uniformity is 1.2. (See Glossary.) This indicates that the lake bottom is slightly concave (fig. 3).

Oneida Lake, as are most natural lakes, is deepest toward its source (on the east) and shallowest toward its mouth (on the west). Numerous shoal areas exist through the lake. The most extensive of these are Shackelton Shoals at mid-lake and Pancake shoals off constantia. Figure 4 shows where five bottom profiles were determined, and figure 5 shows the profiles.

About 25.7 percent of the lake bottom consists of shoal areas or areas shallower than 14 feet $(4.3$ meters). This depth, shown in figure 6 , is considered to be the depth least practical for navigation.

Mean annual discharge from the lake is 2,390 cubic feet $(67.7$ cubic meters) per second or 1,563 million gallons $\left(5.92 \times 10^{9} 1\right.$ iters) per day (U.S. Geological Survey, 1969b). Flow-through time, sometimes called "retention time," is about 235 days. 
Oneida Lake is centrally located in a drainage basin (fig. 7) at the southeast end of Lake Ontario in central New York State. The long axis of the basin is approximately 63 miles (10) kilometers) in length and extends from about $42^{\circ} 47^{\prime}$ to about $43^{\circ} 43^{\prime}$ north latitude. The short axis is approximately 39 miles (63 kilometers) in length and extends from about $75^{\circ} 27^{\prime}$ to about $76^{\circ} 141$ west longltude. The 1,382 square miles $\left(3,579^{\prime \prime}\right.$ square kilometers) of watershed includes parts of Lewis, Oswego, Oneida, onondaga, and Madison Counties.

$$
\begin{aligned}
& \text { Table 1.- - Dimensions of Onelda Lake } \\
& \text { (See Glossary for definition of terms) }
\end{aligned}
$$

Factor

Value or remark

Area

$$
\begin{aligned}
& \text { Drainage area.................................... } 382 \text { q } \mathrm{mi}(3,579 \mathrm{sq} \mathrm{km})
\end{aligned}
$$

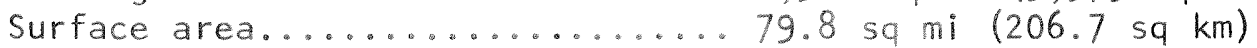

$$
\begin{aligned}
& \text { Shoal area..................20.5 sq } \mathrm{mi}(53.1 \mathrm{sq} \mathrm{km}) \\
& \text { or } 25.7 \text { percent of } \\
& \text { surface area }
\end{aligned}
$$

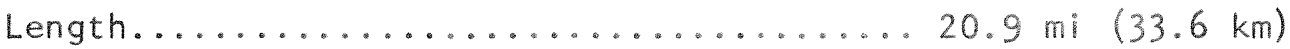

Axis, long......................................... southeast

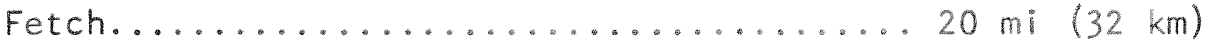

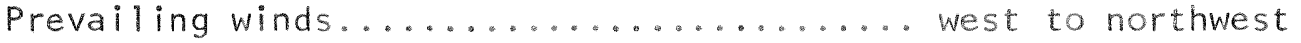

Width

Maximum width.............. $5.5 \mathrm{mi}(8.8 \mathrm{~km})$

Mean width................. $3.8 \mathrm{mi}(6 . \mathrm{km})$

Depth

Maximum depth............... $55.0 \mathrm{ft}(16.8 \mathrm{~m})$

Mean depth................................ $(6.8 \mathrm{~m})$

Shoal depth.................. 14.0 ft $(4.3 \mathrm{~m})$

Volume (at $369 \mathrm{ft}$ stage)..............496 $\times 10^{8} \mathrm{cu} \mathrm{ft}$

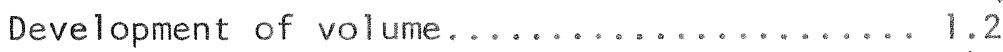

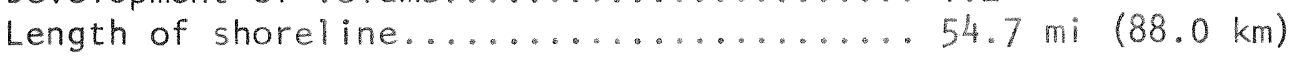

Development of shoreline............. 1.7

Stage

Normal summer stage.............. $369 \mathrm{ft}(112 \mathrm{~m})$

Normal winter stage............ $366 \mathrm{ft}(111 \mathrm{~m})$

Effluent discharge, mean........... 1,563 million gallons per day $\left(59.2 \times 10^{7}\right.$

$\mathrm{m}^{3}$ per day)

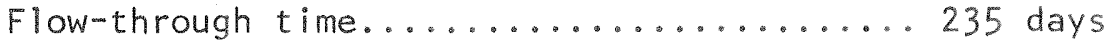




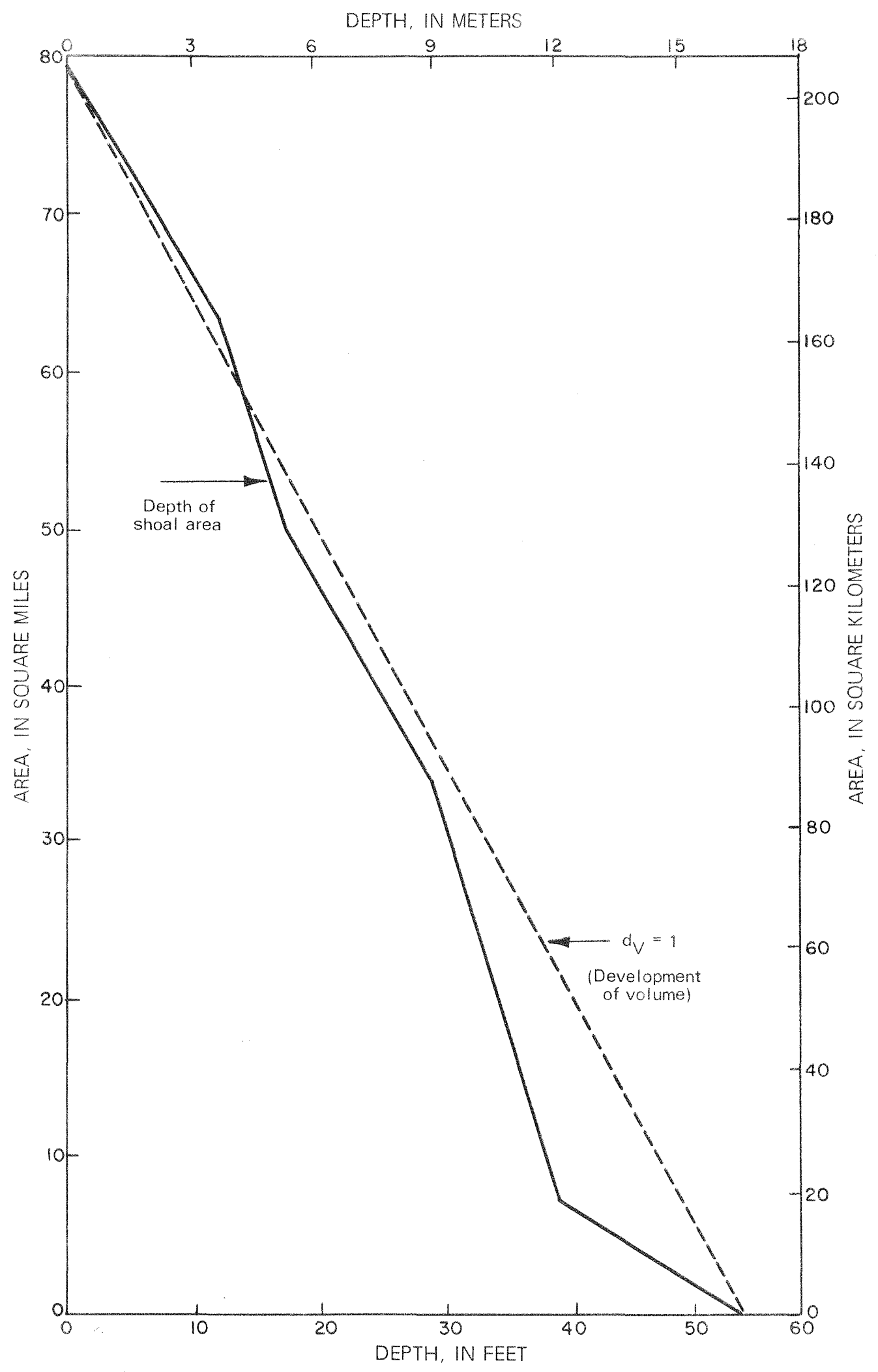

Figure 3.--Area of lake bottom included at various depths (from Greeson and Meyers, 1969). 


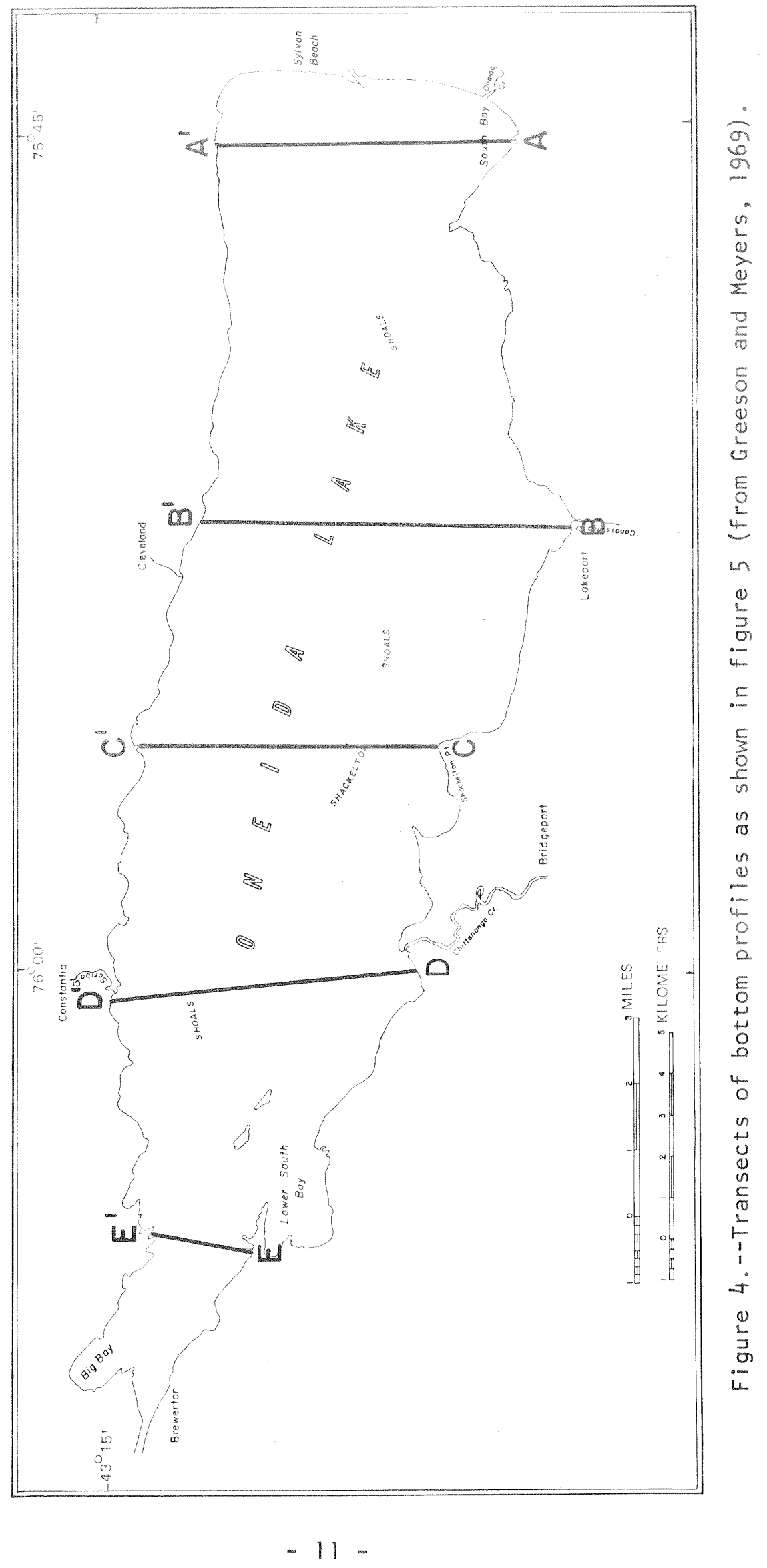




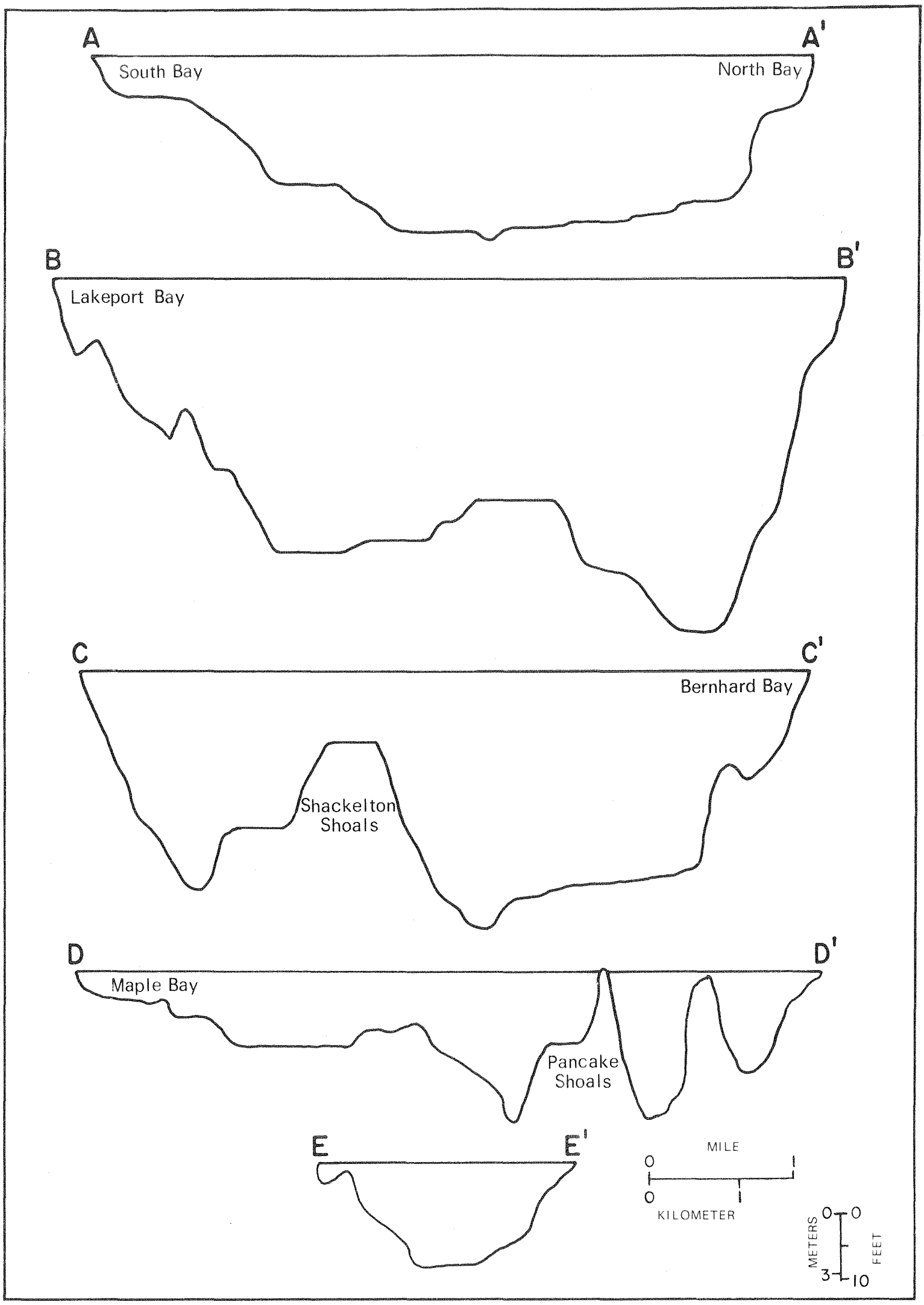

Figure 5.--Bottom profiles. Transects as shown in figure 4 (from Greeson and Meyers, 1969). 


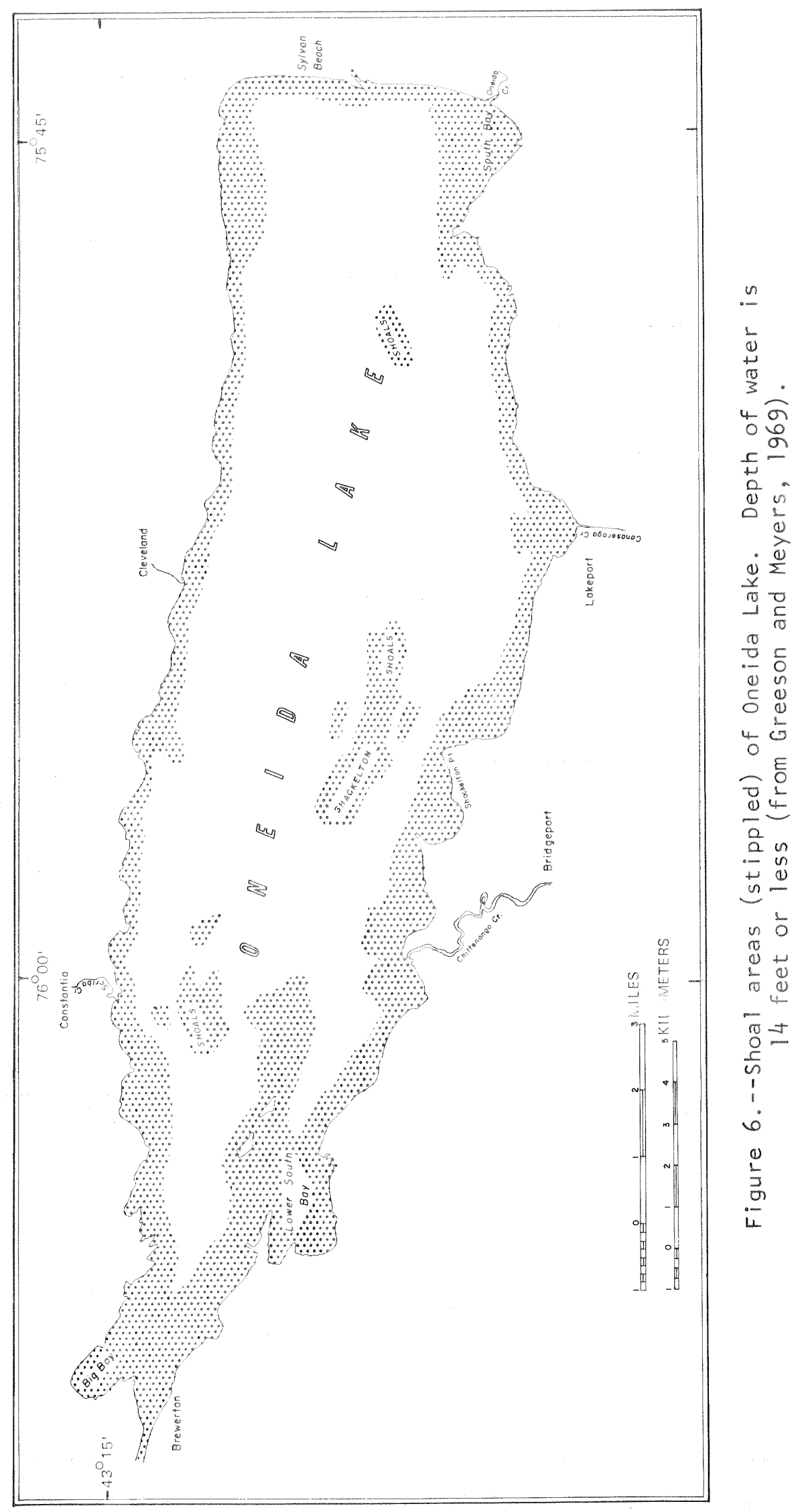




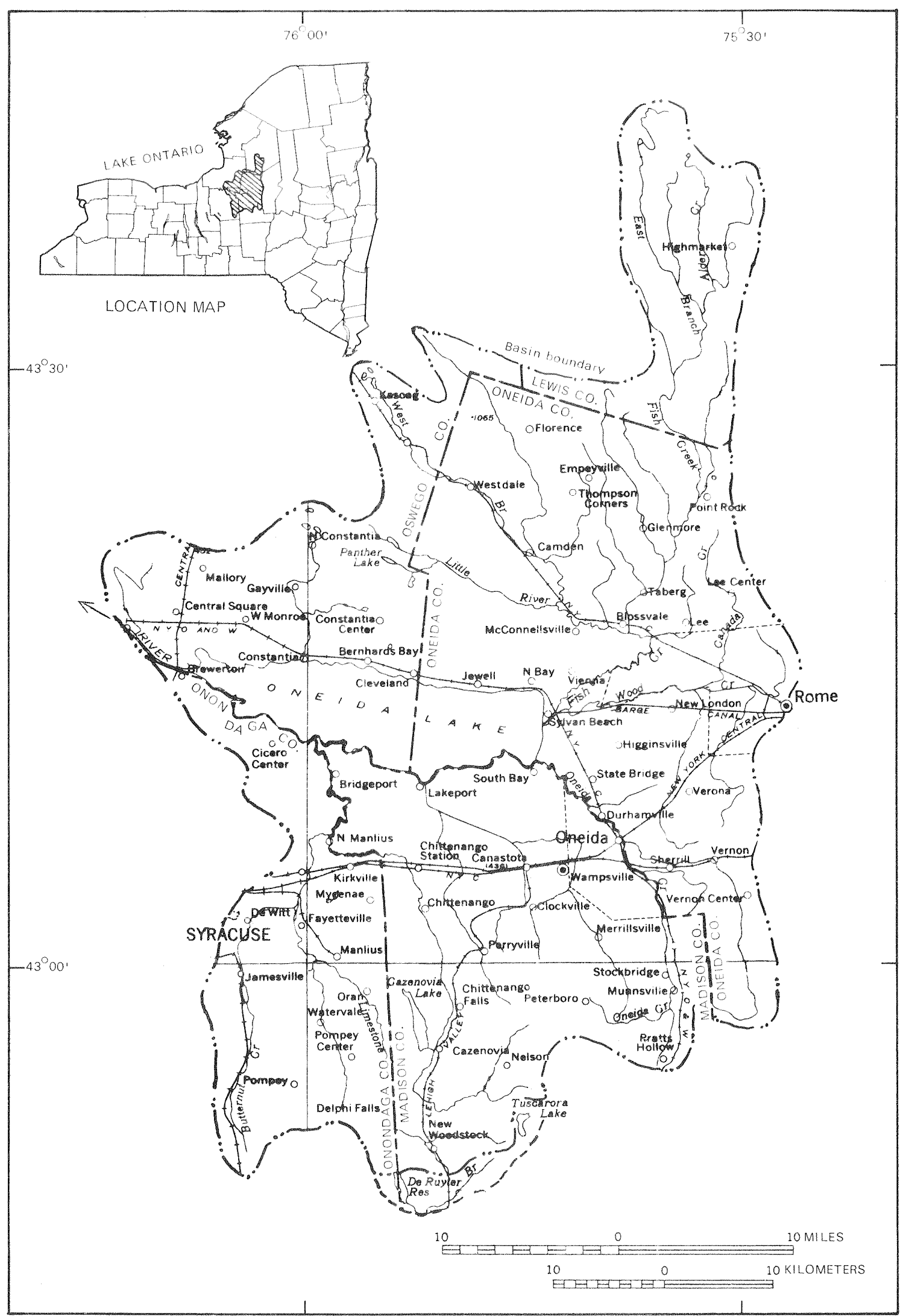

BASE FROM U.S. GEOLOGICAL SURVEY, $1: 500,000$

Figure 7.--Oneida Lake drainage basin. 


\section{Gealogy}

Oneida Lake was preceded by Lake 1roquois, a large late-glacial lake, which was also an ancestor of Lake Ontario and the Finger Lakes of central New York. Lake Iroquois' level remalned stable long enough to develop shoreline features that remained after the lake level dropped. Gravel and sand were deposited along the shore in beaches, bars, spits, and deltas; silt and clay were deposited in areas of deeper water.

Lake Iroquois came into existence upon recession of the glacier from the divide between the Oneida and the Mohawk basins. According to Hough (1958), the east beach of Lake Iroquois extended northeastward to Covey Hill, at the north end of the Adirondack Mountains and about 1 mile ( 1.6 kilometers) north of the international boundary in Ontario. During the melting of the ice sheet, the level of Lake Iroquois was maintained by an outlet on the east. This is known as the Rome outlet (Muller, 1965). The ice sheet to the north prevented outflow through the steeply sloping, broad, low valley of the st. Lawrence River.

After the glacier wasted and receded from the Adirondack Mountains, the drainage of Lake Iroquois shifted to the St. Lawrence valley (MacClintock and Terasmae, 1960). As the St. Lawrence outlet became ice-free, the level of Lake Iroquois gradually lowered. The final sequence in Lake Iroquois history was the formation of short-lived Lake Frontenac (Leverett and Taylor, 1915). The episode was brief, and no separate shorelines are referable to the event.

Radiocarbon dating by Karrow and others (1961) showed that Lake Iroquois existed for about 2,000 years, from 12,500 to 10,500 years ago. Oneida Lake, therefore, has been in existence for about 10,000 years, and part of its watershed was once the bottom of an inland freshwater sea.

Cicero and Canastota Swamps, now mucklands, were originally part of the historic lake sequence, but it is not clear how much time elapsed before these areas became filled. A col at an altitude of 395 feet is located near Lakeport. Another col existed near Bridgeport. The areas south of the two cols are now drained by Chittenango creek and Canaseraga Creek; they consist of extensive muck and (or) peat deposits overlying wellpreserved, charophytically deposited marl. Peat and marl can be readily observed at Oniontown, about 2 miles (3.2 kilometers) southeast of Lakeport. Bays of early Onelda Lake probably extended into these two areas. Upon separation from the lake proper, the two bays became shallow ponds and, finally, filled.

Geologic history and resulting physlographic setting of Oneida Lake are significant because a large part of the nutrients entering any lake become entrapped within it and, ultimately, become part of the bottom sediments. Therefore, part of the bottom sediments with the accumulated nutrients of Lake Iroquois are now the fertile soils of the drainage basin of Oneida Lake. Drainage from these lands brings into the lake an abundance of soluble minerals and dissolved organic materials (Pearson and Meyers, in press), which become nutritive matter for plants, enrich or fertilize the water of the lake, and make it a favorable culture medium for aquatic vegetation. 


\section{Physiography}

Oneida Lake drainage basin is underlain by sedimentary bedrock of Paleozoic age (Broughton and others, 1962), which is undeformed but includes rock units that differ widely in their resistance to erosion. The differences are reflected in three physiographic regions: Erie-Ontario Lowland, in which Oneida Lake is positioned, and Tug Hill and Appalachian Uplands, which border it on the north and south, respectively (Muller, 1965).

Tug Hill Upland, a plateau remnant preserved by the erosional resistance of Ordovician 0swego Sandstone (Muller, 1965), has altitudes approaching 1,950 feet (600 meters).

The northern part of Appalachian Upland is delineated by a north-facing escarpment in the Oneida Lake basin. The escarpment is indented by short north-trending streams with steep gradients and small drainage basins. The altitude at the crest of the escarpment is about 2,000 feet (610 meters).

Erie-Ontario Lowland is a relatively flat region lying entirely below an altitude of 820 feet (250 meters) and averaging about 400 feet (120 meters). The lowland includes the plains bordering Lake ontario and merges east of Oneida Lake with the lowlands through which flow the Mohawk and the Hudson Rivers. Erie-Ontario Lowland differs from the uplands only because of the erosional susceptibility of its underlying bedrock (Muller, 1965). The bedrock is composed of shale, limestone, and minor amounts of sandstone and is overlain with as much as 100 feet (30 meters) of unconsolidated glacial deposits. The limestone units form low ridges (called "cuestas") trending east to west. The topography of the lowland is strongly drumlinized because of extensive glacial modification.

Oneida Lake is the latest water-level stand in a sequence of shrinking and lowering lakes developed in Erie-Ontario Lowland since glaciation. The prolonged stand of Oneida Lake at a surface altitude of about $369 \pm$ feet results from a balance of hydrologic and morphologic conditions.

Pearson and Meyers (in press) state that the Oneida Lake drainage basin could be divided into five hydrochemically distinct and internally homogeneous terranes, exclusive of the lake itself. They are Tug Hill, Lake Plain, Till, Sand and Gravel, and Salina Group Terranes (fig. 8).

Tug Kill Terrane forms 36 percent of the drainage basin and consists entirely of Tug $\mathrm{Hill}$ Upland. It includes most of the region north of the lake and is underlain by chemically unreactive earth materials. The predominant rock is sandstone that is highly resistant to erosion.

Lake Plain Terrane surrounds Oneida Lake and forms 21 percent of the drainage basin. It consists of the Erie-Ontario Lowland described earlier.

The three other terranes form the Appalachian Upland part of the drainage basin. Till Terrane consists of poorly sorted ice-laid glacial deposits with small areas of sand and gravel. These deposits are virtually chemically unreactive. Seventeen percent of the drainage basin is encompassed by Till Terrane. 


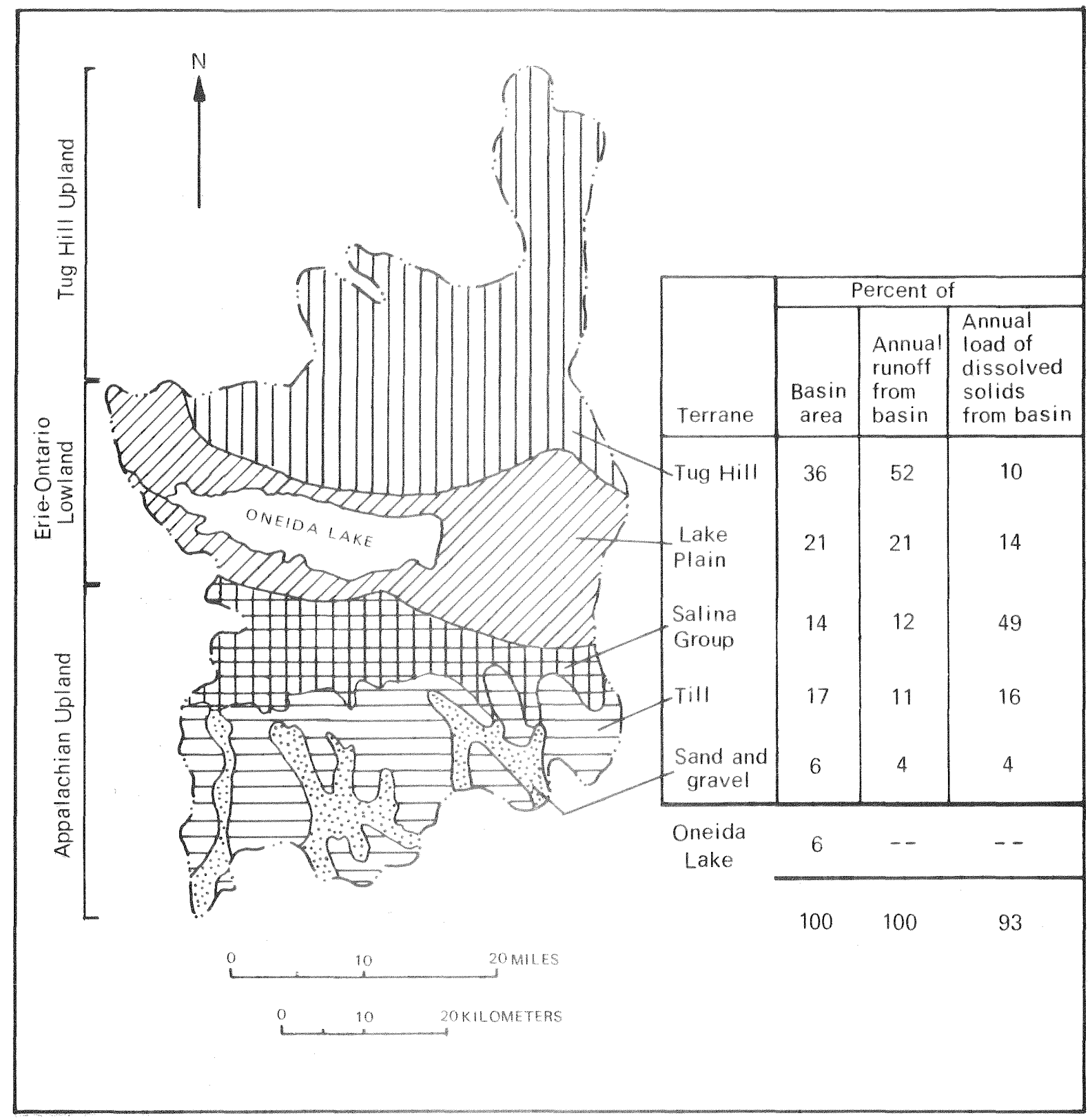

Figure 8.--Oneida Lake drainage basin showing five hydrochemically distinct terranes (from Pearson and Meyers, in press).

Valley Heads Moraine (Muller, 1965) forms the Sand and Gravel Terrane, which is interspersed in the Till Terrane. Well-sorted sand and gravel as well as silt and clay are interbedded with till in these areas that yield relatively large amounts of ground water to the streams. The materials in this 6 percent of the drainage basin have a low content of soluble or reactive mineral matter.

Only one of the consolidated geologic units in the basin has an appreciable direct effect on the hydrochemistry of the streams (Pearson and Meyers, in press). This unit is the Salina Group Terrane, which consists of 
Vernon Shale, Syracuse Salt, Camillus Shale, and Bertie Limestone. Ranging from 700 to 900 feet (213 to 274 meters) in thickness (Leutze, 1964), it is exposed along the lower edge of the escarpment bordering the Appalachian Upland. The group crops out along the sides and the bottoms of some of the deeper valleys cut into the escarpment and extends under the unconsolidated materials in the Erie--Ontario Lowland south of Oneida Lake. The Salina Group Terrane forms 14 percent of the drainage basin.

Salina Group is easily erodable and contributes substantial quantities of dissolved minerals to the streams. These minerals are primarily calcium bicarbonate and calcium sulfate, which originate in carbonate rock (dolomite) beds and shale beds that contain lenses and numerous disseminated grains of gypsum. The syracuse salt of the group contains beds of sodium chloride, which are in contact with ground water.

Data used to prepare figure 8 suggest that the 43 percent of the arainage basin north of Oneida Lake contributes 67 percent of the water and only 18 percent of the dissolved solids entering the lake. On the other hand, the 51 percent of the drainage basin south of the lake delivers 33 percent of the water and 82 percent of the dissolved solids.

Composition of the terrane of each major tributary to Oneida Lake is given in table 2 .

\section{Cultural Development and Land Uses}

Oneida Lake was first visited in the autumn of 1615 by Samuel $D$. Champlain; but it was not until. 1789 that the first resident settled at Fort Brewerton. The first village, New Rotterdam (now called "Constantia"), was established in 1798.

Construction of the Erie Canal in the early 1800's and development of a side-cut from Wood Creek to the canal at Higginsville opened Oneida Lake as a trade route. Development of the lake rapidly increased. A lock and dam were built on the Oneida River at Oak Orchard in 1840 for the improvement of navigation, which was further enhanced by the completion of a lock at Caughdenoy in 1841. The first steamboat was placed on the lake in 1846.

By the late 1840's, cultural development of the lake had increased considerably. Throughmdredging was completed in 1848, and the first plank road was laid along the north shore in 1849. This permitted stage coaches to travel between Syracuse and the rapidly growing villages along the lake. A railroad was built along the north shore in 1868 to increase the shipment of lumber, leather, and window glass, which were manufactured in cleveland.

Caughdenoy Lock and Dam was constructed in 1910, and, with the completion of the New York Barge Canal in 1916, Oneida Lake became a vital link in the route between the Eastern United States and the Great Lakes.

Today, the eastern part of the Barge Canal between Oswego and Albany is heavily traveled. The total freight tonnage in 1962 was approximately 1.5 million. The number of boats carrying this tonnage was estimated at 


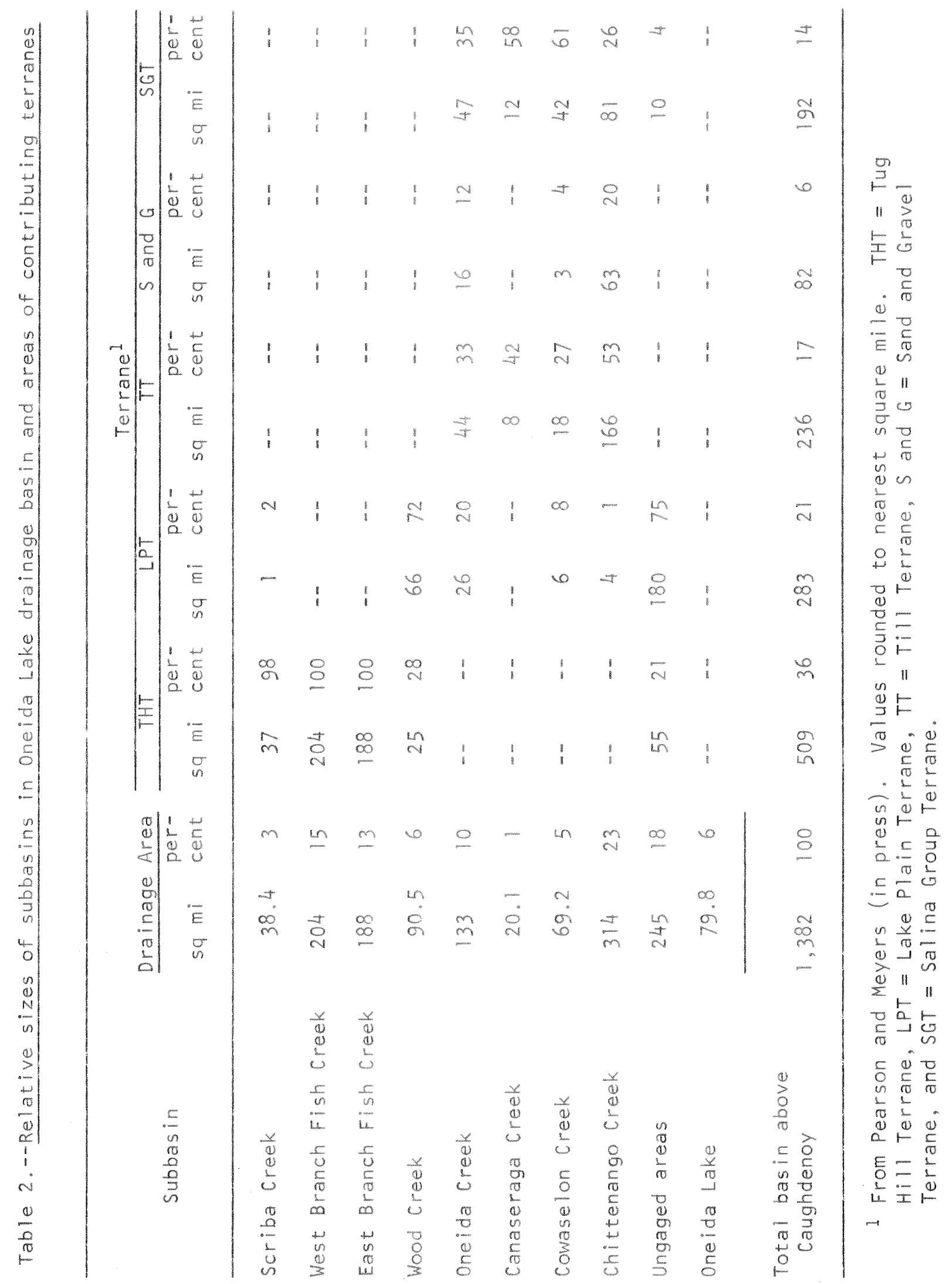


about 750 (U.S. Congress, House of Representatives, Subcommittee of the Committee on Government Operations, 1966).

The number of dwellings on the shore of Oneida Lake increased more than 9 times between 1900 and 1960 (table 3). A cursory survey indicates that most of these dwellings are for permanent residence; the remainder are used as temporary or short-term housing during the summer. On the basis of the average size of a household in the 1960 census, the population of the shoreline increased from 1,600 in 1900 to 14,100 in 1960. In addition to the permanent population, more than 1 million sportsmen and water enthusiasts visit the area annually (U.S. Congress, House of Representatives, Subcommittee of the Committee on Government Operations, 1966).

For this report, the shoreline of Oneida Lake has been defined as extending from the water edge back 0.2 mile (320 meters). In 1900, 71 percent of the shorel ine was undeveloped forestland or wetland. In 1960, the extent of undeveloped land had decreased to less than 50 percent of the total. Development has been greatest along the south shore. This is shown in table 3 by the increase in number of dwellings from 168 in 1900 to 2,582 in 1960--a 1,540 percent increase, or a rate that is almost three times faster than the development along the north shore. Construction of residential areas along the south part of Oneida Lake is continuing today. The information for table 3 was obtained from old and new U.S. Geological Survey topographic maps, U.S. Lake Survey maps, and aerial photographs.

Oneida Lake is used extensively for recreation. A recreational survey by the New York Conservation Department (T. King, written commun., 1969) found 85 commercial recreational facilities. These included 24 private beaches, with a capacity of about 5,700 persons, and marinas for about a 2,000-boat capacity, with the tie-up capacity for another 6,300 boats. There are about 40 commercial boat-launch ramps around the lake. In addition, New York State maintains three public launch sites at Delmarter Bay, Godfrey's Point, and Three Mile Bay. About 35 picnic areas are available to the public.

Sylvan Beach, a public beach, and Verona Beach State Park offer virtually unlimited facilities for swimming and picnicking. Records from Verona Beach State Park indicated an attendance of 161,207 persons during the 1968 season.

More than 5,000 boats have been reported using Oneida Lake on a typical summer day (Federal Water Pollution Control Administration, 1968). An aerial survey by the New York Conservation Department on August 3, 1969, showed 985 motorboats, 140 sallboats, 50 yachts, 230 rowboats, and 120 water skiers at 1530 hours.

A similar aerial survey at 1500 hours on February 25, 1968, counted 40 snowmobiles, 5 automobiles, and 100 persons ice fishing. Oneida Lake is a truly year-round recreational lake.

Grosslein (1961) estimated that during the summer and the winter of 1959-60, more than 1.3 million man-hours were spent by fishermen on Oneida Lake. He estimated the catch of walleyed pike (Stizostedion vitreum), 


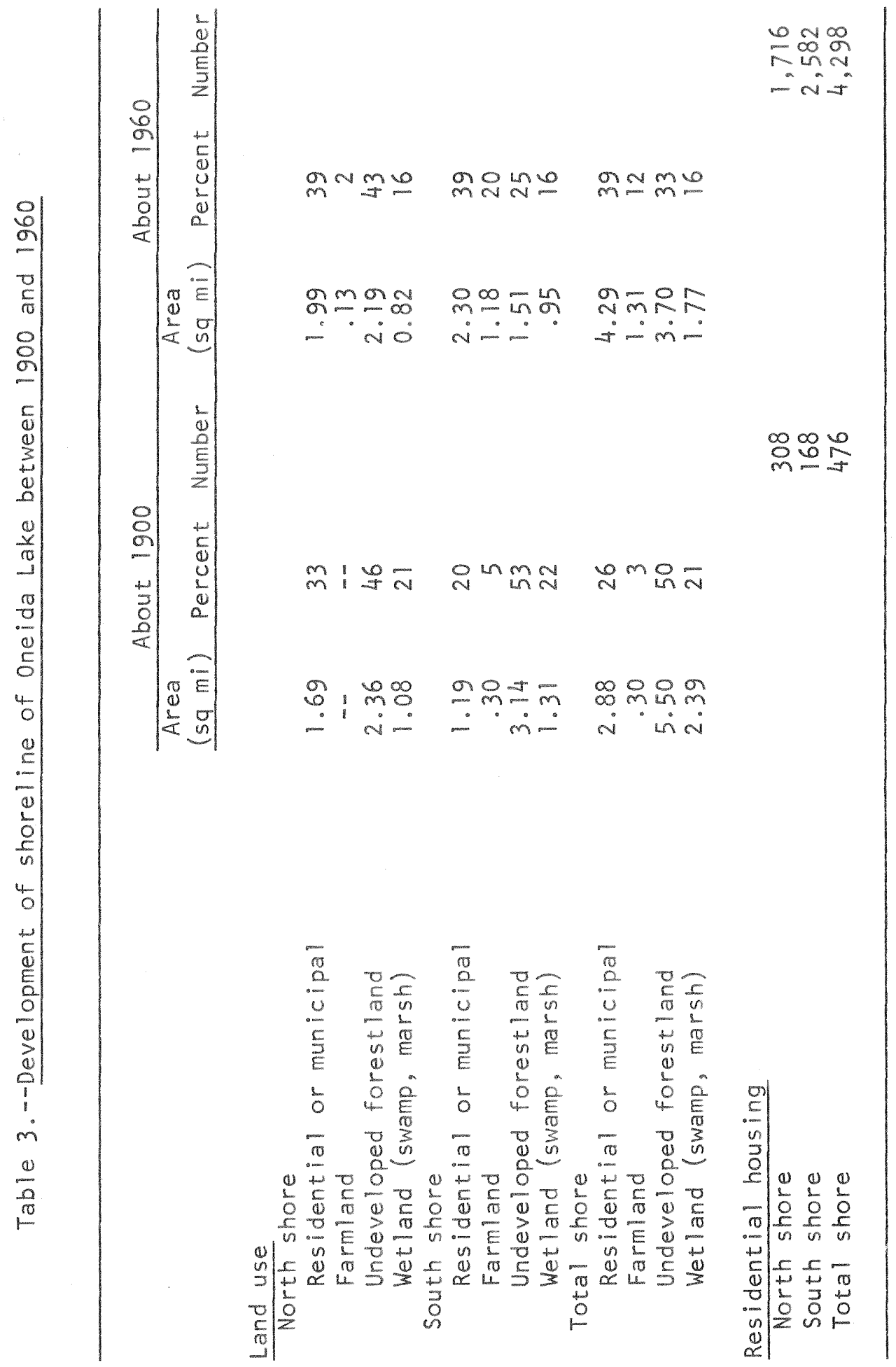


smallmouth bass (Microptems dolomieui), and vellow perch (Perca flavescens) to total about 690,000 . This was in addition to the catch of other fishes.

Artificial propagation of walleyed pike is done at New York State's Fish Hatchery at Constantia. The culture of walleyed pike was started in 1893. During a normal spawning season, a total of 315 million eggs are processed (N. Youmans, written commun., 1967).

According to the LUNR (Land Use and Natural Resources) program developed by the Center for Aerial Photographic Studies at Cornell University (R. L. Sheldon, written commun., 1970), the drainage basin north of the lake is primarily undeveloped forestland and wetland. About 76 percent of the area is undeveloped. Only 15 percent of the north part of the basin is used for farming, whereas less than I percent of the north area is used for residential and commercial purposes.

In the south part of the basin, about 56 percent of the land is farmed. Dairy farms are numerous in the Appalachian Upland region, and truck farming is common in the Lake Plain south of Oneida Lake. Principal crops are onions, carrots, and potatoes. About 33 percent of the south basin is undeveloped forestland and wetland. Five percent of the south area is used for residential and commercial purposes. This latter includes the east fringes of the city of syracuse.

Table 4, developed from the LUNR program, shows land uses of the tributary basins to Oneida Lake and for the entire bas in above Caughdenoy Dam. More than 54 percent of the total drainage basin is undeveloped (that is, forestland and wetland), and about 35 percent is used for farming. Oneida Lake drainage basin, therefore, can be considered primarily rural.

Population of the basin is greatest south of the lake. About 85,000 people (U.S. Congress, House of Representatives, Subcommittee on Government operations, 1966) in 17 major communities live in the drainage basins of Chittenango, Canaseraga, and Oneida Creeks. Eight of the communities, exclusive of syracuse, are sewered and have primary sewage-treatment facilities. The population served by these facillities totals about 29,800 (Federal Water Pollution Control Administration, 1968).

Only about 6,200 persons reside in the sparsely populated area north of Oneida Lake. They are concentrated in seven major communities, only one of which is partly sewered. 
Table 4.- - Percentage land uses of the Oneida Lake drainage basin

\begin{tabular}{|c|c|c|c|c|c|}
\hline Drainage basin & $\begin{array}{c}\text { Residential } \\
\text { and } \\
\text { commercial }\end{array}$ & Farmland & Forestland & Wet $l$ and & $\begin{array}{l}\text { Other } \\
\text { uses }^{1}\end{array}$ \\
\hline Scriba Creek & $<1$ & 15 & 53 & 31 & $<1$ \\
\hline West Branch Fish Creek & $<1$ & 16 & 68 & 13 & 2 \\
\hline East Branch Fish Creek & $<1$ & 7 & 78 & 13 & 1 \\
\hline Wood Creek & 2 & 34 & 46 & 13 & 5 \\
\hline Oneida Creek & 3 & 62 & 30 & 2 & 3 \\
\hline $\begin{array}{l}\text { Canaseraga and Cowaselon } \\
\text { Creeks }\end{array}$ & 3 & 61 & 28 & 6 & 2 \\
\hline Chittenango Creek & 6 & 50 & 28 & 7 & 9 \\
\hline Ungaged areas & 3 & 38 & 40 & 16 & 3 \\
\hline Lake surface & 0 & 0 & 0 & 0 & 100 \\
\hline $\begin{array}{c}\text { Total basin above } \\
\text { Caughdenoy Dam }\end{array}$ & 3 & 35 & 43 & 11 & 8 \\
\hline
\end{tabular}

1 includes water surfaces, transportation surfaces, industrial and extractive areas, and natural sand and rock surfaces. 
Sampling Network

Routine field investigations of chemical and biological characteristics of Oneida Lake and drainage basin were started in May 1967 and continued until October 1969. A network of 25 sampling stations was established for uniformity in sampling. Locations of 16 lake stations plotted on figure 9 are given in table 5. The remaining nine stations will be discussed later.

During a few periods of adverse weather, when sampling was impossible by boat, samples were collected from station $21 \mathrm{~b}$ at the outlet of Oneida Lake at Brewerton. Analyses of samples collected at that location and at station 21 a are reported as data for station 21 (table 33.)

Mid-lake sampling stations $(8,12,15,18$, and 21a) were located at navigation buoys of the New York State Department of Transportation. The other 10 sampling stations were marked by location buoys. Each international ofange location buoy, shown in figure 10, was constructed of Styrofoam and measured $22 \times 22 \times 8$ inches $(56 \times 56 \times 20$ centimeters). A steel rod, 3 feet $(0.9$ meter) in length, was mounted through each buoy and a red flag was attached. The buoy was anchored by a 150 pound $(68 \mathrm{kllogram}$ ) block of concrete. The buoys were visible with the unaided eye at a distance of about 2.5 miles ( 4.0 kilometers).

To determine the relative contributions of water and dissolved solids from each of the tributaries to Oneida Lake, a network of nine tributary stations was established, including a station at Caughdenoy Dam to measure the total outflow from the drainage basin. Methods for determining water and nutrient budgets from the subbasins are discussed in later sections of this report.

Locations of the sampling stations (fig. 11 and table 6) were selected because of their proximity to the lake and immunity from lake backwater. The stations coincided with elther continuous-recording streamgaging stations or long-term partial surface-water record stations. The stations are shown in figures 12 through 16.

For this report, reference to a tributary or tributary basin includes that part upstream from the respective sampling station. Ungaged areas include downstream parts of the drainage bas in that are not included in the sampling-station network. 


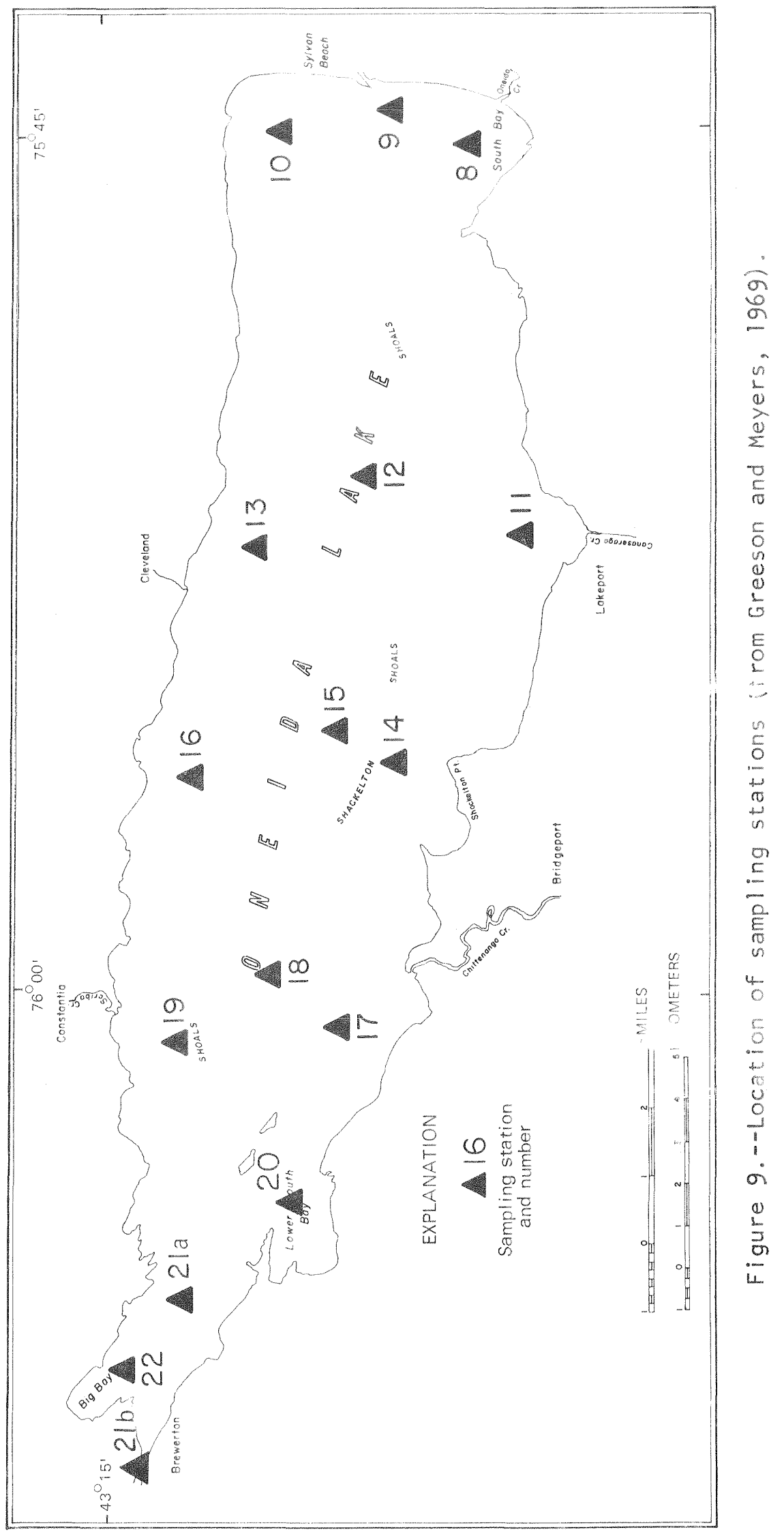


Table 5.--Approximate locations of sampling stations on Oneida Lake

\begin{tabular}{|c|c|c|}
\hline $\begin{array}{l}\text { Sampling } \\
\text { station }\end{array}$ & $\begin{array}{l}\text { U.S. } \\
\text { Geological } \\
\text { Survey } \\
\text { station }\end{array}$ & Location \\
\hline 8 & 04245904 & $\begin{array}{l}75^{\circ} 45^{\prime} \mathrm{W} \text {, about } 1 \text { mile north of south } \\
\text { shore (South Bay) }\end{array}$ \\
\hline 9 & 04245900 & $75^{\circ} 45^{\prime} \mathrm{W}$, midlake at buoy $107-\mathrm{FIW}$ \\
\hline 10 & 04245901 & $\begin{array}{l}75^{\circ} 45^{\prime} \text { W, about } 1 \text { mile south of north } \\
\text { shore (North Bay) }\end{array}$ \\
\hline 11 & 04245932 & $\begin{array}{l}75^{\circ} 50^{\prime} \mathrm{W} \text {, about I mile north of south } \\
\text { shore (Lakeport Bay) }\end{array}$ \\
\hline 12 & 04245934 & $75^{\circ} 51^{\prime} \mathrm{W}$, midlake at buoy $117-\mathrm{FIW}$ \\
\hline 13 & 04245940 & $\begin{array}{l}75^{\circ} 52^{\prime} \mathrm{W} \text {, about } 1 \text { mile south of north } \\
\text { shore }\end{array}$ \\
\hline 14 & 04245954 & $\begin{array}{l}75^{\circ} 55^{\prime} \mathrm{W} \text {, about I mile north of } \\
\text { Shackelton Point }\end{array}$ \\
\hline 15 & 04245955 & $75^{\circ} 55^{\prime} \mathrm{W}$, midlake at buoy $123-\mathrm{FlW}$ \\
\hline 16 & 04245961 & $\begin{array}{l}75^{\circ} 56^{\prime} \mathrm{W} \text {, about I mile south of north } \\
\text { shore }\end{array}$ \\
\hline 17 & 04245978 & $\begin{array}{l}76^{\circ} 00^{\prime} \mathrm{W} \text {, about I mile north of south } \\
\text { shore (Maple Bay) }\end{array}$ \\
\hline 18 & 04245970 & $75^{\circ} 59^{\prime} \mathrm{W}$, midlake at buoy $129-\mathrm{FlW}$ \\
\hline 19 & 04245975 & $\begin{array}{l}76^{\circ} 00^{\prime} \mathrm{W} \text {, about I mile south of north } \\
\text { shore between Little Island and } \\
\text { Long Island }\end{array}$ \\
\hline 20 & 04245988 & $\begin{array}{l}76^{\circ} 04^{\prime} \mathrm{W} \text {, about geographical center } \\
\text { of Lower South Bay }\end{array}$ \\
\hline $21 \mathrm{a}$ & 04245995 & $76^{\circ} 05^{\prime} \mathrm{W}$, midlake at buoy $134-\mathrm{FIR}$ \\
\hline $21 \mathrm{~b}$ & 04246000 & $\begin{array}{c}\text { Below U.S. Highway } 11 \text { bridge at gage } \\
\text { house in Brewerton (lake outlet) }\end{array}$ \\
\hline 22 & 04245998 & $\begin{array}{l}76^{\circ} 07^{\prime} \mathrm{W} \text {, about geographical center } \\
\text { of Big Bay }\end{array}$ \\
\hline
\end{tabular}




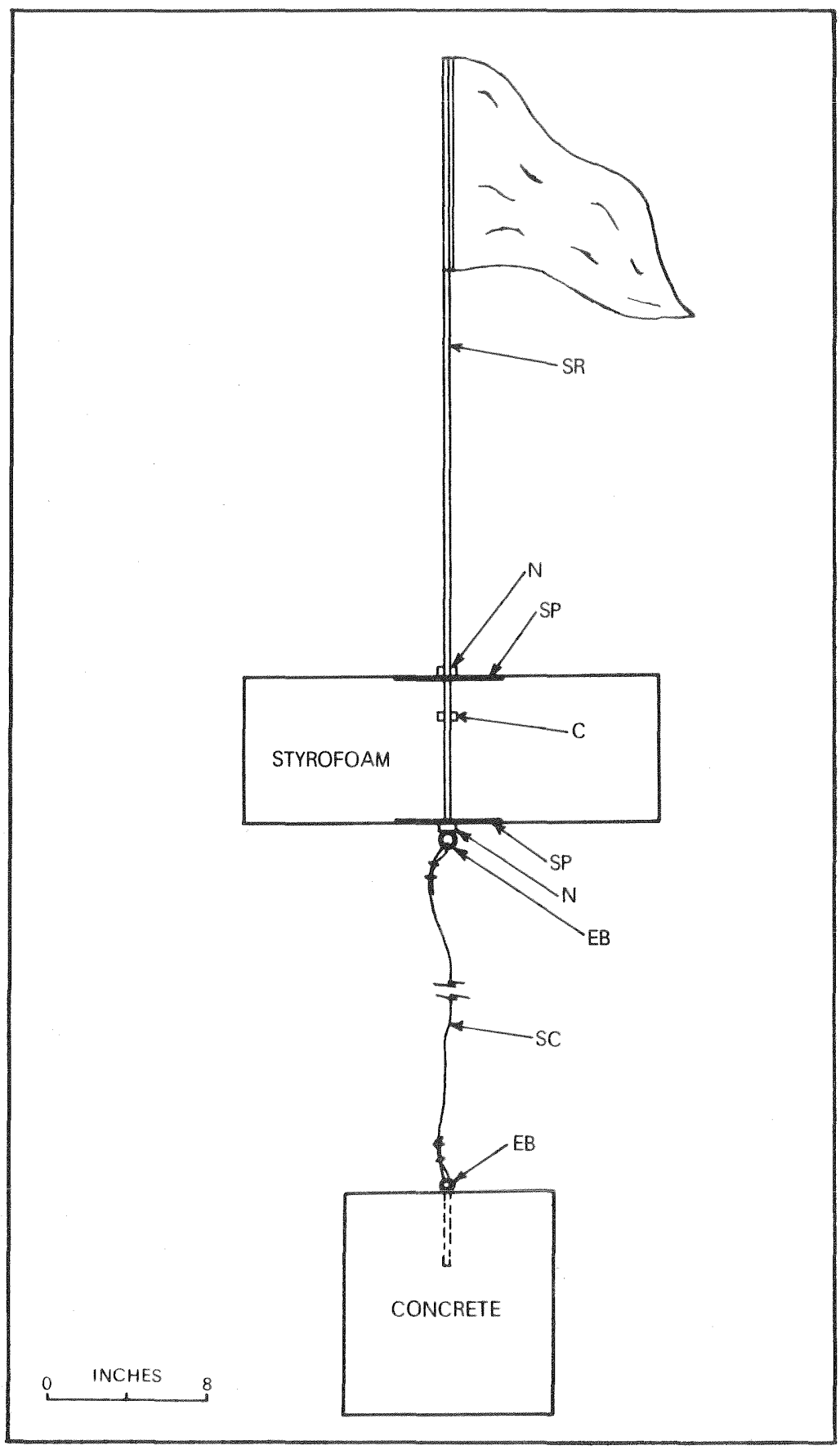

Figure 10.--Sampling-station location buoy. C, Coupler; EB, Eye Bolt; $N$, Nut; SC, Steel cable; SP, Steel plate; and SR, Steel rod. 


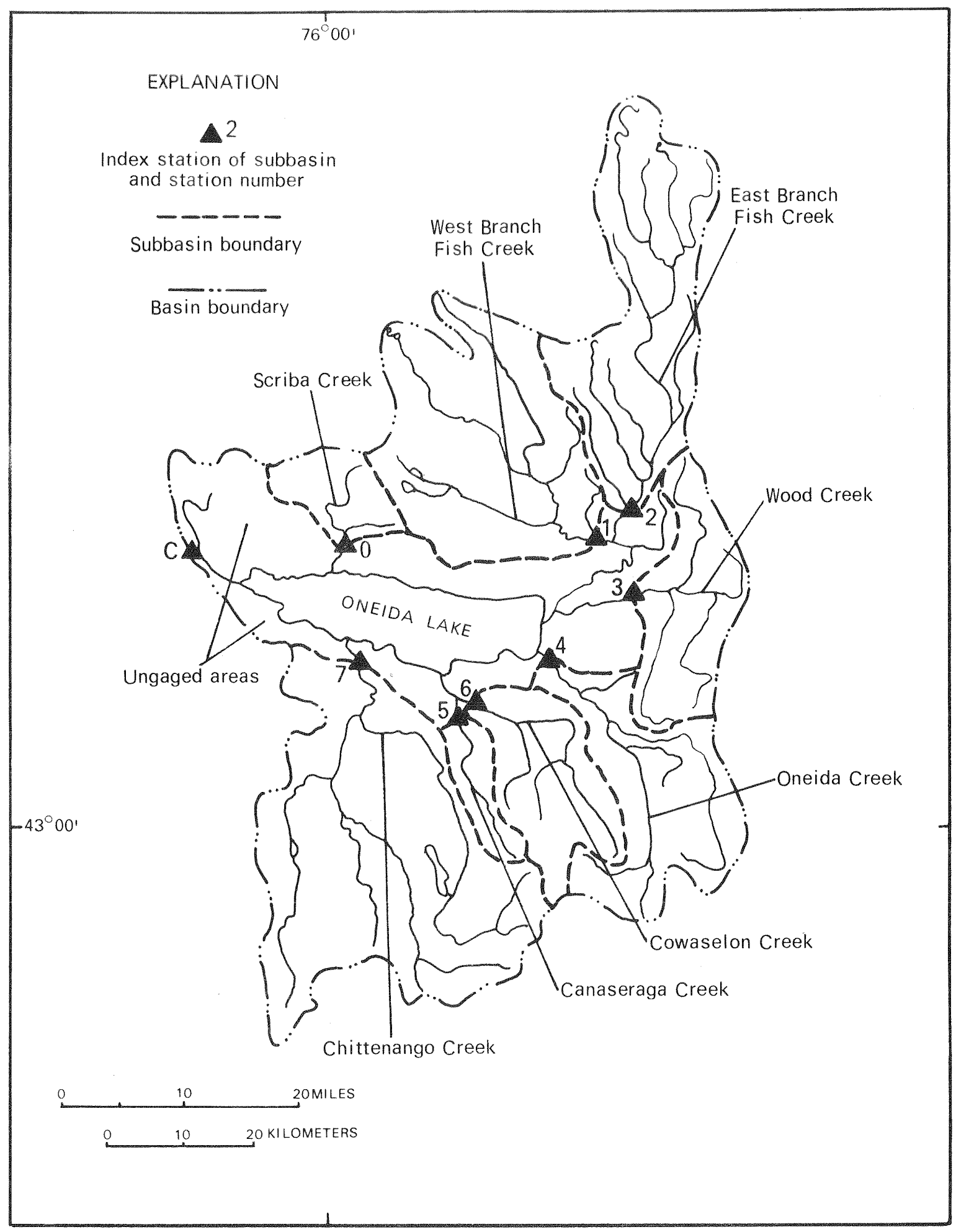

BASE FROM U.S. GEOLOGICAL SURVEY

Figure 11.--Locations of tributaries, subbasins, and sampling stations in Oneida Lake drainage basin. 
Table 6.--Locations of sampling stations in Oneida Lake drainage basin

\begin{tabular}{|c|c|c|}
\hline $\begin{array}{l}\text { Sampling } \\
\text { station }\end{array}$ & $\begin{array}{l}\text { U.S. } \\
\text { Geological } \\
\text { Survey } \\
\text { station }\end{array}$ & Location \\
\hline $\mathrm{c}$ & 04246601 & Oneida River below dam at Caughdenoy \\
\hline 0 & 04245840 & $\begin{array}{l}\text { Scriba creek at bridge on road to } \\
\text { Ingersoll Cemetery near Constantia }\end{array}$ \\
\hline 1 & 04241200 & $\begin{array}{l}\text { West Branch Fish Creek at bridge on } \\
\text { McConnelsville-Blossvale Road, } 0.4 \\
\text { mile southwest of Blossvale }\end{array}$ \\
\hline 2 & 04242500 & $\begin{array}{l}\text { East Branch Fish Creek at bridge on } \\
\text { State Highway } 69 \text { at Taberg }\end{array}$ \\
\hline 3 & 04242800 & $\begin{array}{l}\text { Wood Creek at bridge on State Highway } \\
49,1.2 \text { miles north of New London }\end{array}$ \\
\hline 4 & 04243530 & $\begin{array}{l}\text { Oneida Creek at bridge on State High- } \\
\text { way } 31 \text { at Oneida Valley }\end{array}$ \\
\hline 5 & 04243700 & $\begin{array}{l}\text { Canaseraga Creek at bridge on Tag } \\
\text { Road, } 3.4 \text { miles southeast of } \\
\text { Lakeport }\end{array}$ \\
\hline 6 & 04243800 & $\begin{array}{l}\text { Cowaselon Creek at bridge on Gees Road } \\
\text { at Oniontown }(2.7 \text { miles south of } \\
\text { Lakeport) }\end{array}$ \\
\hline 7 & 04245500 & $\begin{array}{l}\text { Chittenango Creek at bridge on State } \\
\text { Highway } 31 \text { at Bridgeport }\end{array}$ \\
\hline
\end{tabular}




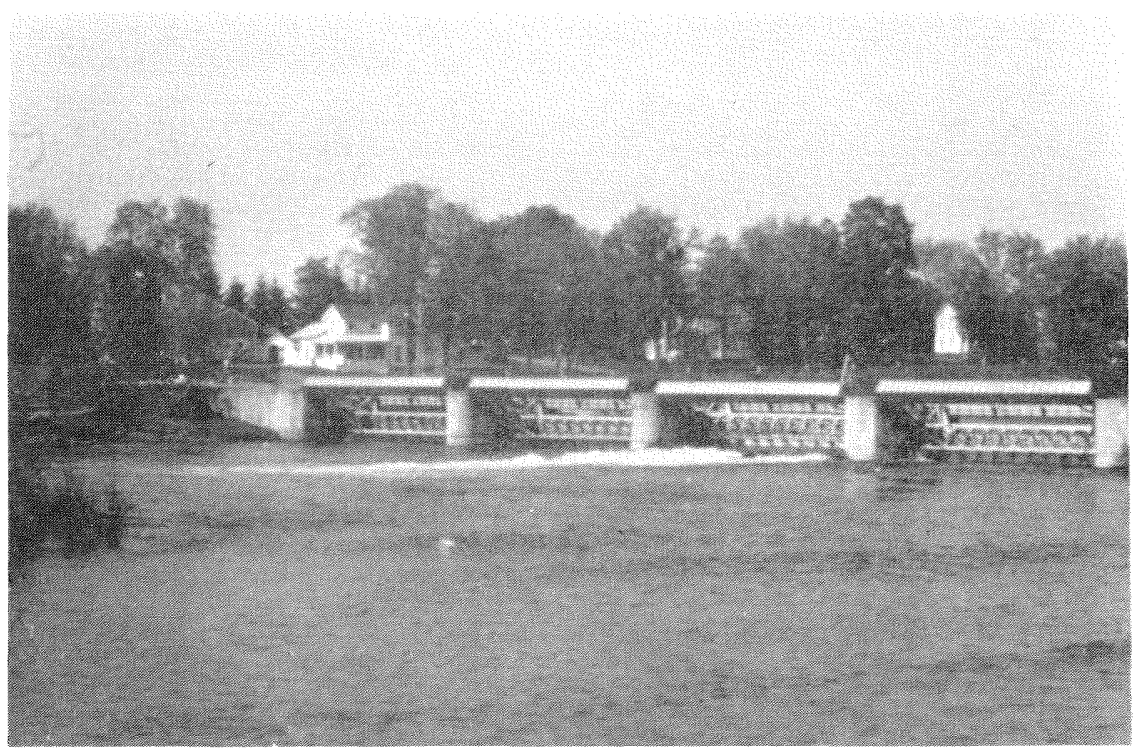

Figure 12.--Caughdenoy Dam on the Oneida River (sampling station C). 


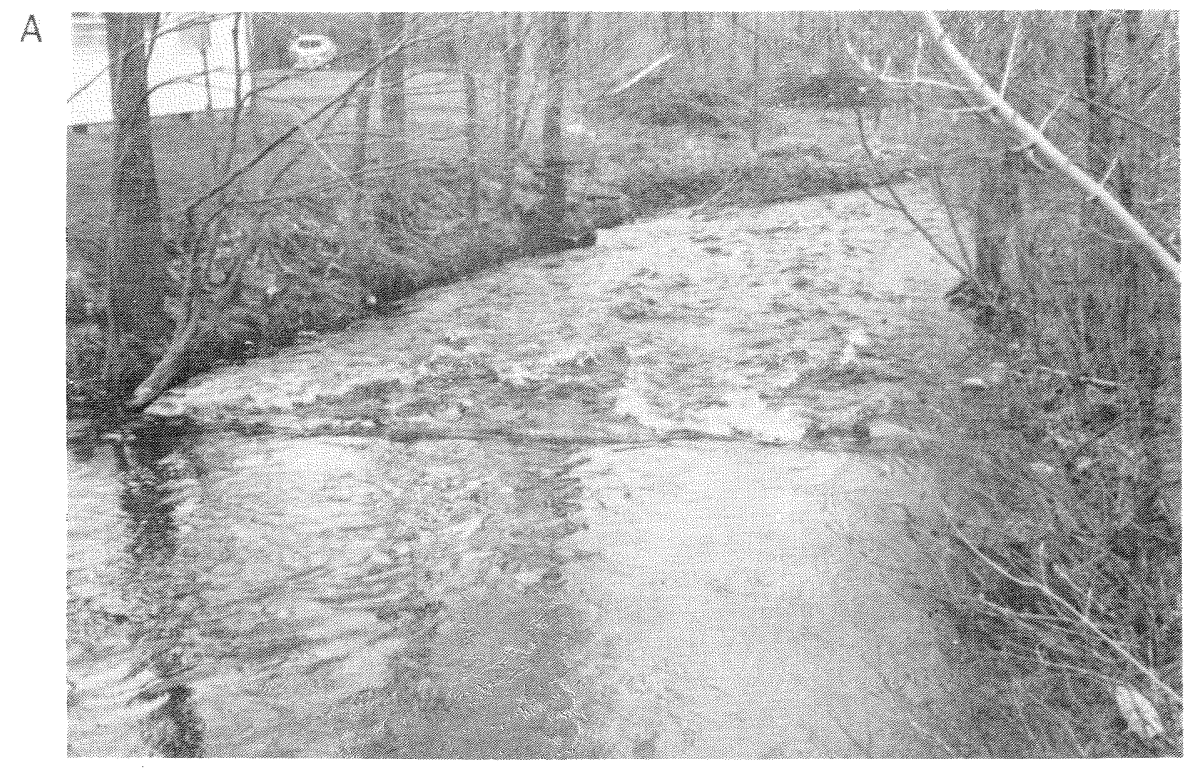

B

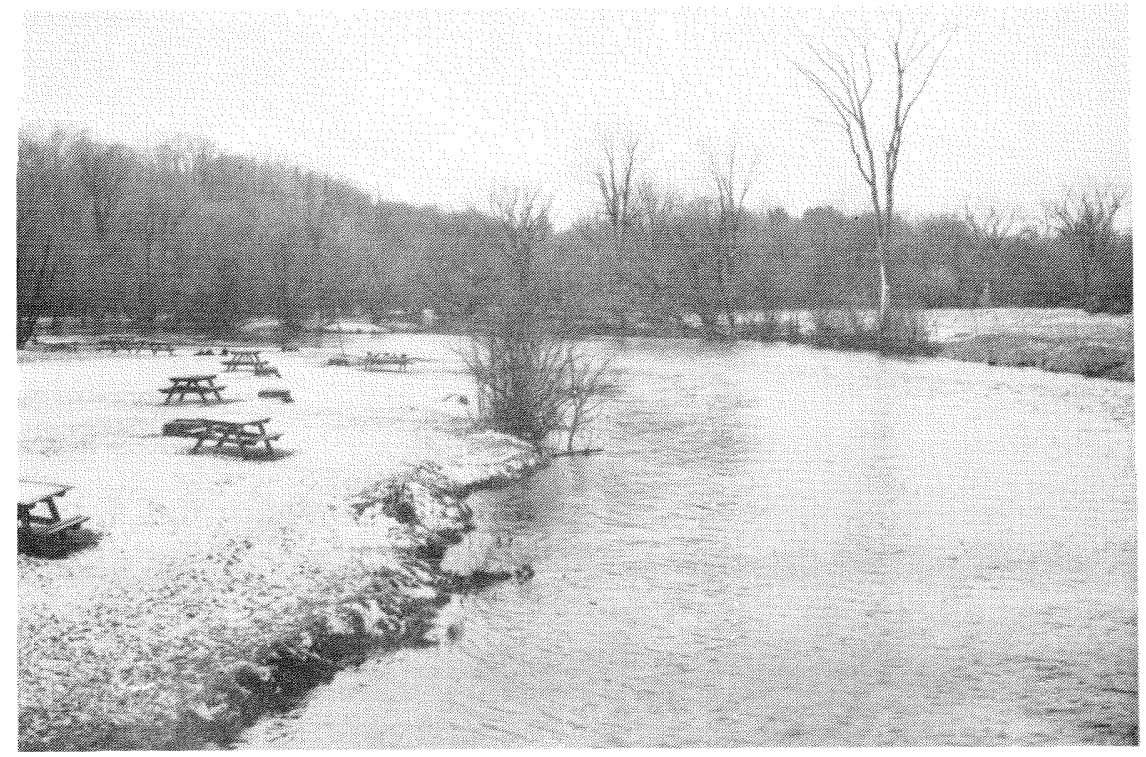

Figure 13.--A. Scriba creek near Constantia (sampling station 0 ).

B. West Branch Fish Creek near Blossvale (sampling station 1). 


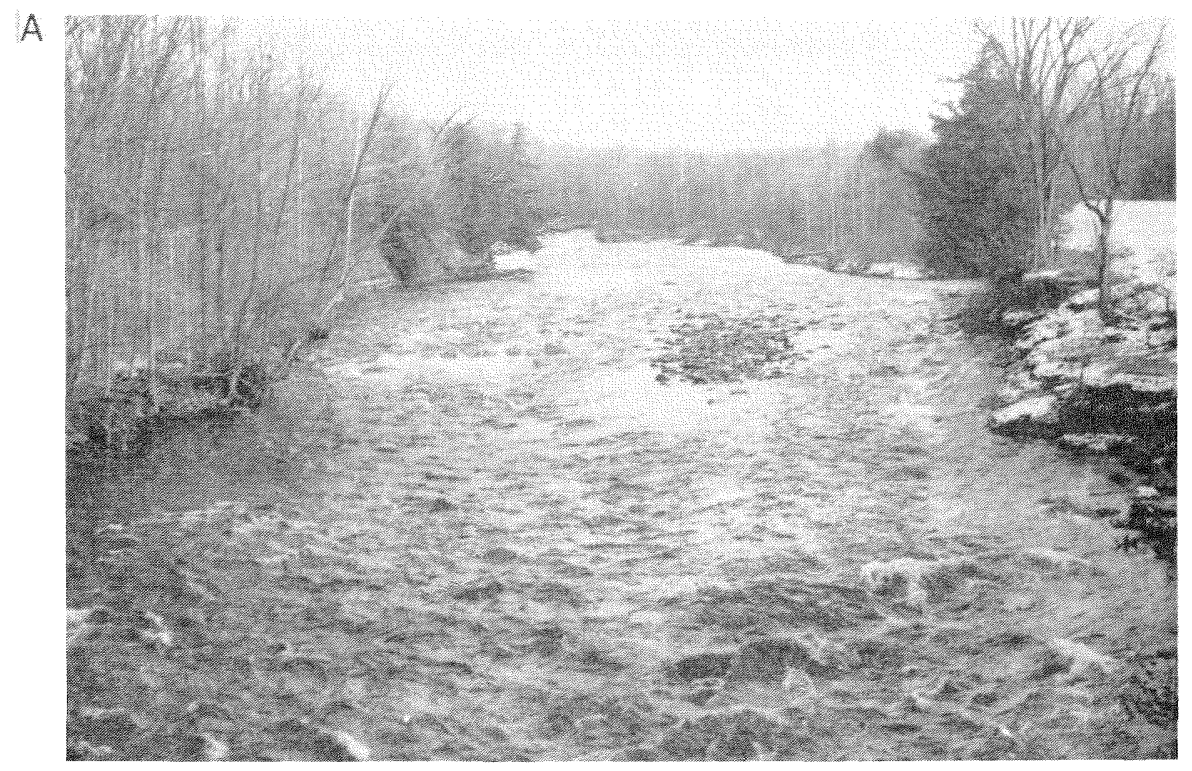

B

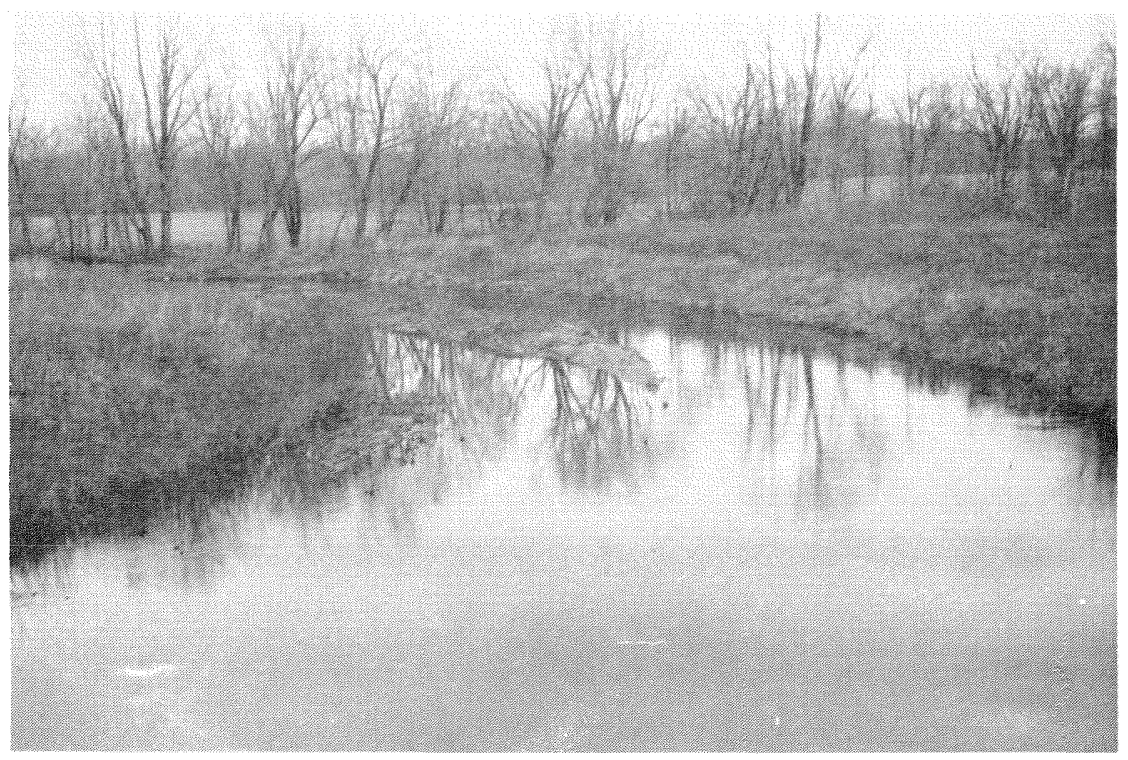

Figure 14.--A. East Branch Fish Creek at Taberg (sampling station 2) B. Wood Creek near New London (sampling station 3 ). 
Water in Oneida Lake is from precipitation directly on the lake surface or watershed. Some of the precipitation returns to the atmosphere by evapotranspiration. The remainder flows through the basin into the lake and drains from the basin by the oneida River.

The amount of precipitation on the basin varies areally from north to south. South of oneida Lake, precipitation generally ranges from 38 inches ( 96.5 centimeters) to 42 inches (106.7 centimeters) per year and averages 40.2 inches (102.1 centimeters) (fig. 17).

The area north of oneida Lake lies in the snow-belt and has a high annual rate of precipitation and large accumulations of snow because of strong, water-laden prevalling winds off Lake Ontario. The higher altitude of the area (for example. Tug Hill) cools the easterly moving air masses to produce precipitation. The mean annual precipitation in the north part of the basin is 49.1 inches (124.7 centimeters) and generally ranges from 40 inches (101.6 centimeters) to 60 inches (152.4 centimeters).

Mean annual precipltation on the drainage basin of Oneida Lake is 44.0 inches ( 111.8 centimeters). Direct precipitation on the surface of Oneida Lake is 38.5 inches $(97.8$ centimeters) per year. The mean annual precipitation for each of the sub-basins is listed in table 7.

The difference between amount of precipitation on the drainage basin of Oneida Lake and amount of water fllowing into the lake represents evapotranspiration from the basin. The amount of ground water, to be discussed later, is included in the surface-water runoff. The total discharges of the subbasins is 2,388 cubic feet ( 67.6 cubic meters) per second, which equals about $1,729,000$ acre-feet $\left(213 \times 10^{7}\right.$ cubic meters) of water per year. Forty-four inches ( 111.8 centimeters) of precipitation on 1,302 square miles (3,359 square kilometers) of watershed is equal to about $3,070,000$ acre-feet $\left(379 \times 10^{7}\right.$ cubic meters) of water. Evapotranspiration from the drainage basin is the difference between the two volumes (precipitation and discharge), or about 1,341,000 acre-feet $\left(165 \times 10^{7}\right.$ cubic meters) or 19.2 inches $(48.8$ centimeters) per year. Therefore, 56 percent of the precipitation on the drainage basin eventually flows into Oneida Lake.

Ground water is not lost from the basin's hydrologic system because it flows to the lowest levels, the valleys containing tributaries to the lake. Ground water may discharge to the streams by springs or, more commonly, by imperceptible seepage. During prolonged dry periods, seepage contributes most of the streamflow. Low-flow discharges from the major tributaries to Oneida Lake are listed in table 7.

For the basin as a whole, the lowest level of the water table is oneida Lake. Kantrowitz (1970) estimates that, at maximum, no more than 1 percent of the water entering Oneida Lake is ground water. Pearson and Meyers (in press) indicate that ground-water contribution to the lake is closer to 0.1 percent of the total inflow. In either case, the percentage contribution is well within the margin of error in computation; therefore, groundwater inflow to Oneida Lake can be considered as negligible. 


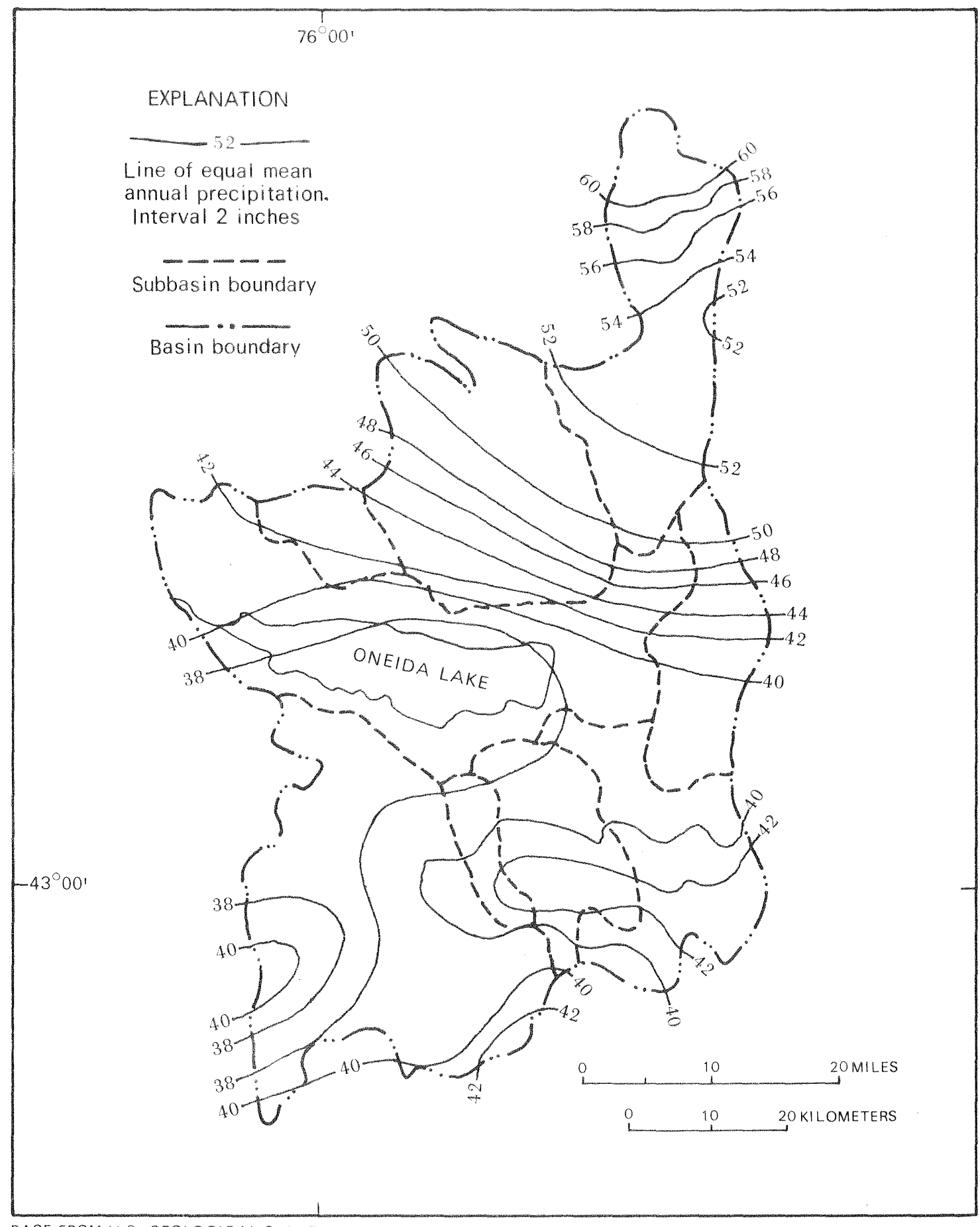

BASE FROM U.S. GEOLOGICAL SURVEY

Figure 17.- - Mean annual precipitation for Oneida Lake drainage basin, 1931-60 (0. P. Hunt, written commun., 1969). 
Table 7.---Precipitation and discharge for the subbasins

in the Oneida Lake drainage bas in

\begin{tabular}{|c|c|c|c|c|}
\hline Drainage basin & $\begin{array}{c}\text { Mean annual } \\
\text { precipitation } \\
\text { (inches per year) }\end{array}$ & $\begin{array}{l}\text { Mean } \\
\text { disch } \\
\text { (cfs) }\end{array}$ & $\begin{array}{l}\text { nual } \\
\text { ge } \\
\text { (cfsm) }\end{array}$ & $\begin{array}{l}\text { Low flow }{ }^{2} \\
(c f s)\end{array}$ \\
\hline Scriba Creek & 44.6 & 80 & 2.08 & 7 \\
\hline West Branch Fish Creek & 48.8 & 499 & 2.45 & 65 \\
\hline East Branch Fish Creek & 55.1 & 555 & 2.95 & 21 \\
\hline Wood Creek & $43 \cdot 3$ & 140 & 1.55 & -- \\
\hline Oneida Creek & 40.5 & 173 & 1.30 & 25 \\
\hline Canaseraga Creek & 40.2 & 27 & 1.36 & 2.5 \\
\hline Cowaselon Creek & 39.8 & 95 & 1.38 & 14 \\
\hline Chittenango Creek & 40.6 & 425 & 1.35 & 35 \\
\hline Ungaged areas & 39.5 & 394 & 1.61 & $-\infty$ \\
\hline Lake Surface & 38.5 & -- & -- & -- \\
\hline $\begin{array}{l}\text { Total basin } \\
\quad \text { (at Caughdenoy Dam) }\end{array}$ & 43.7 & 2,390 & 1.73 & 112 \\
\hline
\end{tabular}

I Values represent discharge for standard period, 1931-1960.

2 Values represent discharge for 7 day -2 year recurrence intervals.

Streamflow in the basin varies with the amount of precipitation. During periods of heavy rainfall or snow melt, overland runoff causes occasional floods. The annual high flow in tributaries to Oneida Lake generally can be expected during April: low flow occurs during August or september.

Amount of water in the basin varies annually because of variations in precipitation. For many streams, long periods of continuous records are available from which mean annual flows and flows at other time intervals can be estimated. The same information can be obtained by a variety of methods (Hunt, 1963, and Riggs, 1968) for ungaged streams or for those streams where only a few instantaneous discharge measurements have been made. For uniform comparison, mean annual discharges of the tributaries to Oneida Lake and of the entire basin have been estimated for a standard 30-year period, 1931-1960 (0. P. Hunt, written commun. 1969) (table 7). 
During the 3-year study, discharge past Caughdenoy Dam varied slightly from the long-term average of 2,390 cubic feet $(67.7$ cubic meters) per second. In the 1967 water year (that is, October 1966 through September 1967), average outflow was 1.819 cubic feet (51.5 cubic meters) per second or 23.9 percent lower than the long-term average (U.S. Geological Survey, 1968). The 1968 and the 1969 water years were above average; the flows were 2,647 cubic feet $(75.0$ cubic meters) per second and 2,897 cubic feet (82.0 cubic meters) per second, respectively (U.S. Geological Survey, 1969b and 1970b). They represented a 10.8 percent and a 21.2 percent increase over the long-term average.

Evaporation from Oneida Lake was determined indirectly as the difference between the evapotranspiration from the total drainage area above Caughdenoy Dam and the evapotranspiration from the drainage basin of the lake. This can be expressed as:

$$
E_{L S}=E T_{D A}-E T_{D B}
$$

where $E_{L S}$ is the annual rate of evaporation from the lake surface times 79.8 square miles (206.7 square kilometers), ETDA is the evapotranspiration from the total drainage area above Caughdenoy Dam times 1,382 square miles (3,579 square kilometers), and ETDB is the evapotranspiration from the drainage bas in of Oneida Lake times 1,302 square miles (3,359 square kilometers).

The method used for estimating evapotranspiration from the drainage bas in of Oneida Lake was also used for estimating evapotranspiration from the drainage area above Caughdenoy Dam. Table 7 shows that the annual precipitation in the area above the dam equals 43.7 inches $(111.0$ centimeters), or about $3,220,000$ acre-feet $\left(397 \times 10^{7}\right.$ cubic meters). Mean annual discharge past the dam is 2,390 cubic feet $(67.7$ cubic meters) per second or about $1,730,000$ acre-feet $\left(213 \times 10^{7}\right.$ cubic meters). Evapotranspiration from the drainage area above Caughdenoy Dam is the difference between the two volumes or about $1,490,000$ acre-feet $\left(184 \times 10^{7}\right.$ cubic meters) or 20.2 inches ( 51.3 centimeters) per year.

Use of the preceding equation shows that evaporation from the surface of Oneida Lake is about 36 inches (92 centimeters) per year.

Water in Oneida Lake, as indicated by stage and (or) volume, represents a dynamic equilibrium of hydrologic conditions (fig. 18). The stage of the lake at about 369 feet (112 meters) altitude is maintained by an equal inflow and outflow of water. When inflow exceeds outflow, as during the annual spring runoff, the stage of the lake rises. When outflow through the Oneida River exceeds inflow to the lake, as during the dry months of August and September, the stage of the lake gradually lowers. 


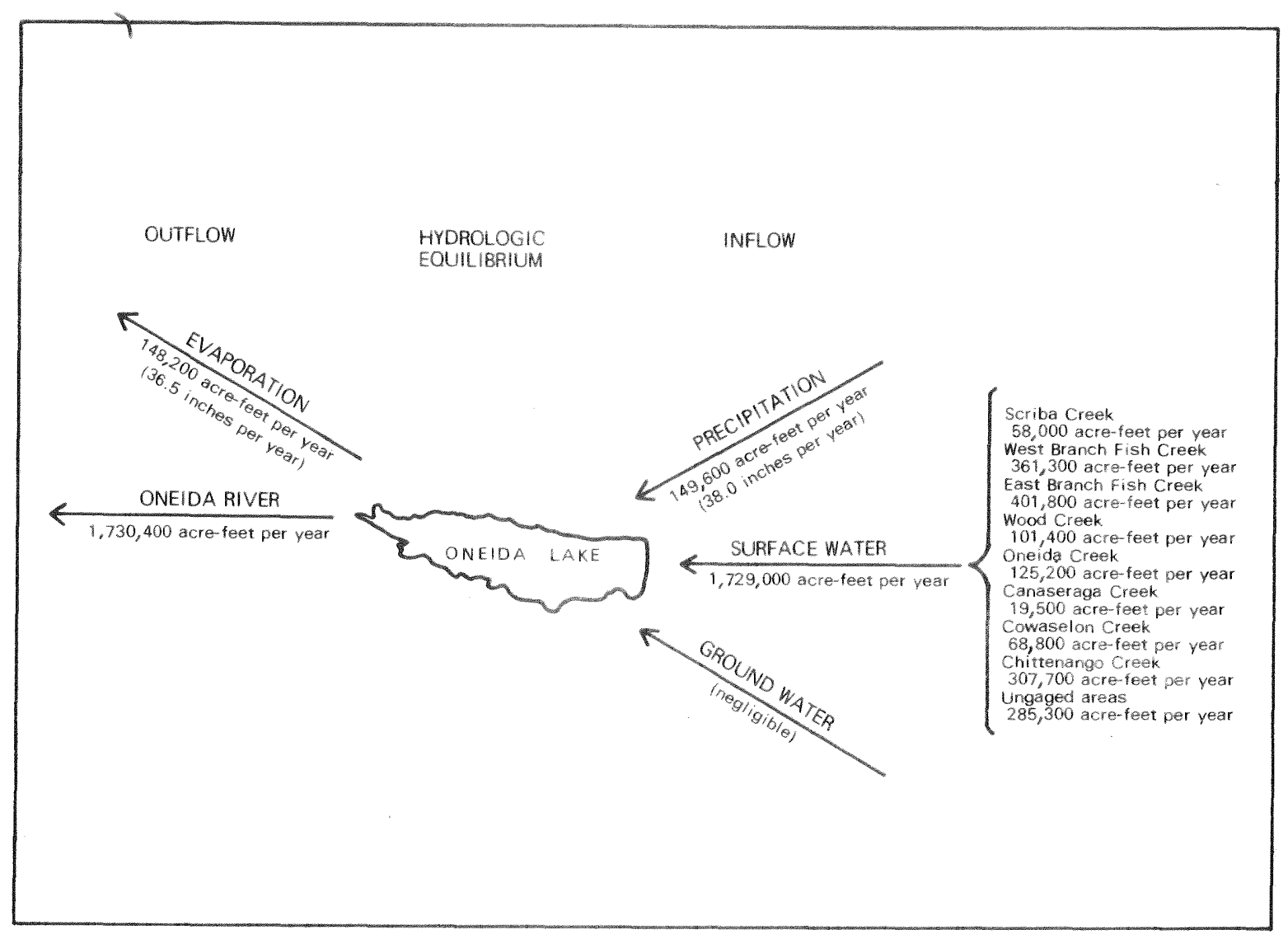

Figure 18.--Water budget of Oneida Lake.

\section{Bottom Sediments}

The major quantity of sedimentary materials in a lake is derived from decaying plant and animal matter and from the sediments originating in the lake's drainage basin. Tributaries to Oneida Lake carry solid materials, both mineral and organic in origin. Some of the materials are in colloidal suspension, and some are maintained in suspension by upward components of turbulent currents. Other solids are carried in the bedload sediment. The ability of each stream to transport sediment varies proportionally with velocity; therefore, some sediment deposition normally occurs whenever the velocity of a sediment-laden stream decreases. Because the velocity of a stream decreases abruptly where the stream enters the lake, deposition occurs. The relative size of deposited particles decreases with increased distance from the mouth of the tributary.

The near-shore bottom sediments in Oneida Lake generally are characteristic of the surficial geology of the watershed drained by each stream. For example, the vast deposits of sand in the eastern part of the lake typify sandstones in the watersheds of Fish and Wood Creeks (fig. 19). Long-shore currents and wave action account for shifting of the sandy sediments. 


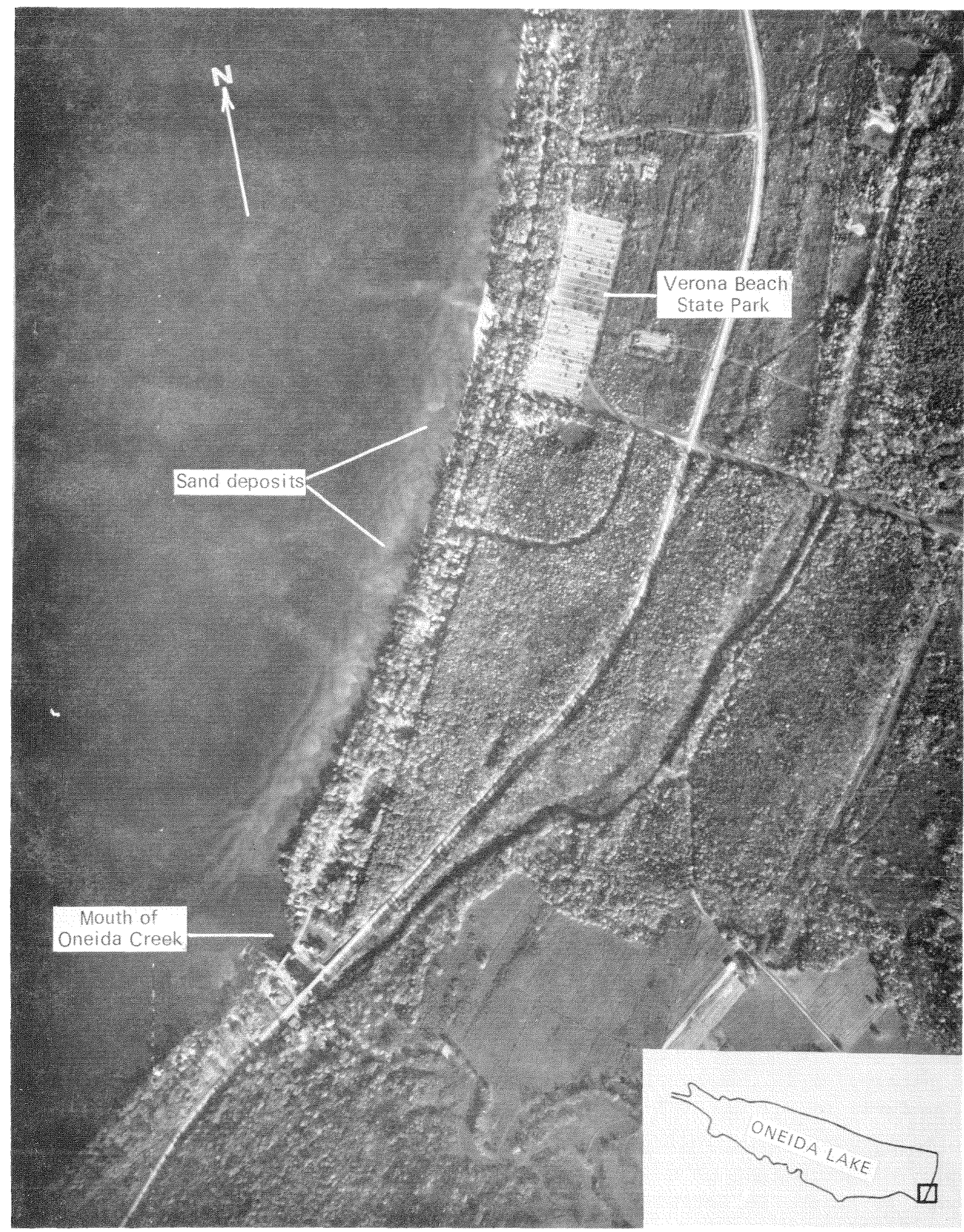

$9+2.12 \mathrm{MLE}$

Figure 19.--Development of sandy beaches in the southeastern part of Oneida Lake. (Photograph courtesy of Rome Air Development Center, Griffiss Air Force Base, New York.) 
Sediments of the deeper lake consist of fine materials such as silt, clay, and precipitated colloids transported by currents. In some places, significant quantities of sediments are the remains of plant and animal matter.

Organic matter, whether allochthonous (from the tributaries) or autochthonous (produced in the lake), decomposes and oxidizes in the aerobic (oxygenated) parts of the lake. Organic deposition, during periods of large algal blooms and in anaerobic zones, occurs when biological production exceeds oxidizing capacity of the water. This results in higher concentrations of organic detritus in the bottom sediments of deepwater areas. Highly productive areas of the lake, as in a bay choked with vascular vegetation, also exhibit accumulations of organic debris.

During this study, types and distribution of bottom materials in Oneida Lake were determined from several hundred Eckman dredge samples taken randomly. Sediments from deep-water areas were sampled with a Peterson dredge (fig. 20A). Additional information was obtained by visual observation of divers and by visual surveys of nearshore areas.

Bottom materials from 27 locations in Oneida Lake were obtained on May 8, 1968, and again on August 14, 1969. The character of these materials was determined by the methods of Mahin and Carr (1923). Results are shown in table 8.

On the basis of composition and size of materials, bottom sediments of Oneida Lake can be divided into five types: (1) cobble and rubble, (2) gravel, (3) sand, (4) silt and clay, and (5) mud. Areal distribution of bottom materials in Oneida Lake is illustrated in figure 21 .

Mud, as defined for this report, includes a mixture of silt, clay, and organic matter; it has the appearance and texture of black ooze. Cobble and rubble in Oneida Lake date from glacial times and were deposited as drumlins (Baker, 1916c). Four major drumlins exist in the lake; the largest is Shackelton Shoals. The others in order of decreasing size include Pancake Shoals, Frenchman and Dunham |slands, and Messenger Shoals. Gravel also was glacially deposited.

silt and clay, the dominant sedimentary material, occupies 32.2 square miles ( 83.4 square kilometers) or 40.3 percent of the bottom of Oneida Lake. Mud occuples 22.0 square miles $(57.0$ square kilometers) or 27.5 percent of the bottom; sand, 14.1 square miles $(36.5$ square kilometers) or 17.8 percent; cobble and rubble, 8.1 square miles (21.0 square kilometers) or 10.2 percent; and gravel, 3.4 square miles ( 8.8 square kilometers) or 4.2 percent.

Except for higher concentration of organic matter, mud has a composition similar to that of silt and clay. Distribution of mud, in most locations, is below the contour depth of oxygen stratification. (See "Vertical Stratification." )

Oneida Lake was originally mapped in 1911 by the U.S. Army Corps of Engineers $(1912 \mathrm{a}, 1912 \mathrm{~b})$. Concurrent observations of bottom types were made. A comparison of these early observations with the present distribution of bottom materials indicates only minor, insignificant changes in the past 60 years. 


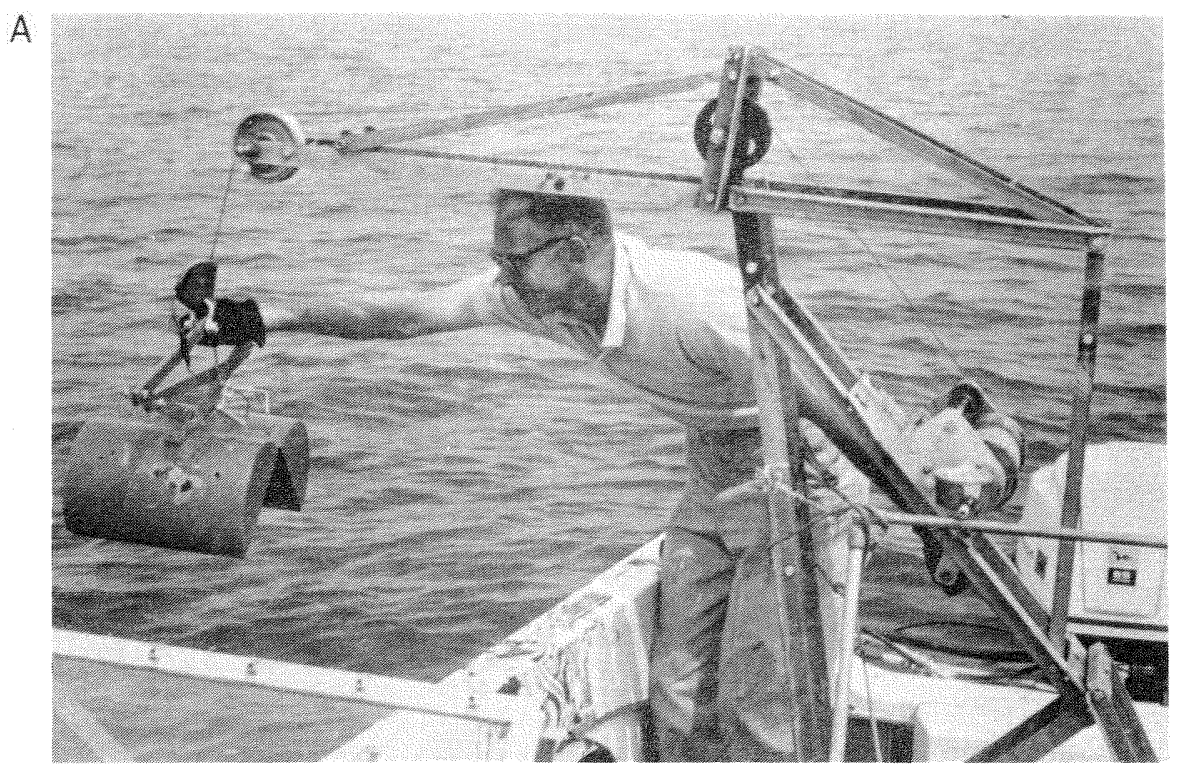

$B$

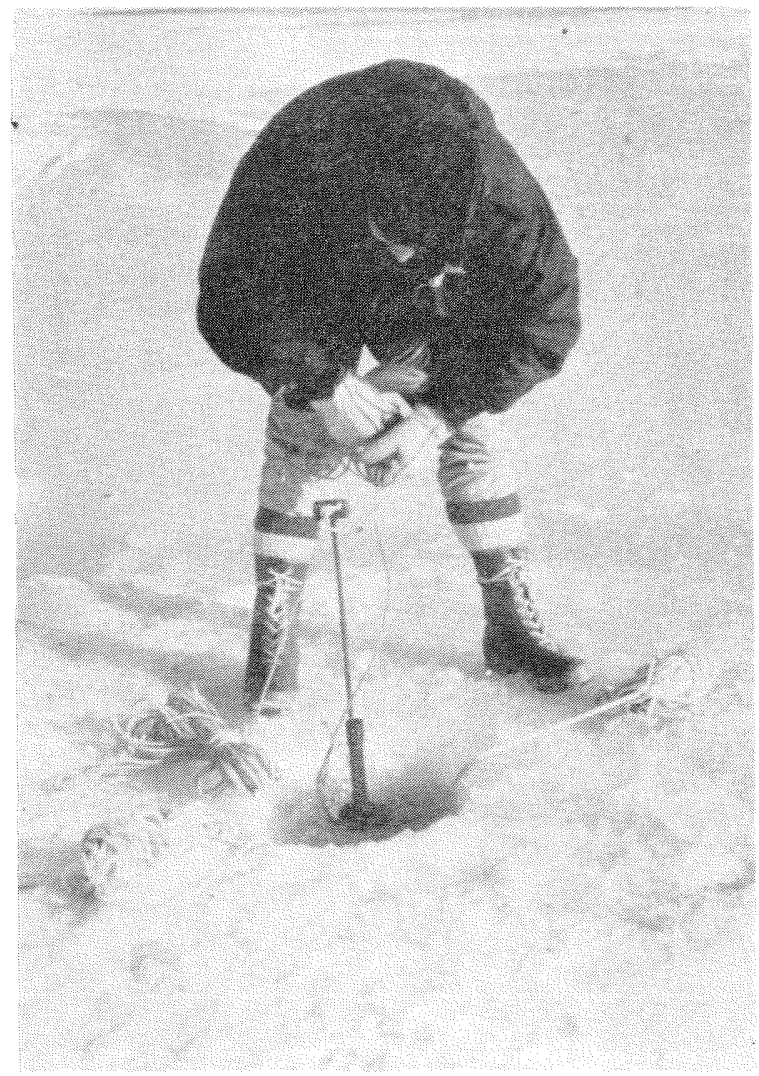

Figure 20.--Collection of bottom samples from Oneida Lake with Peterson dredge (A) and piston corer (B). 


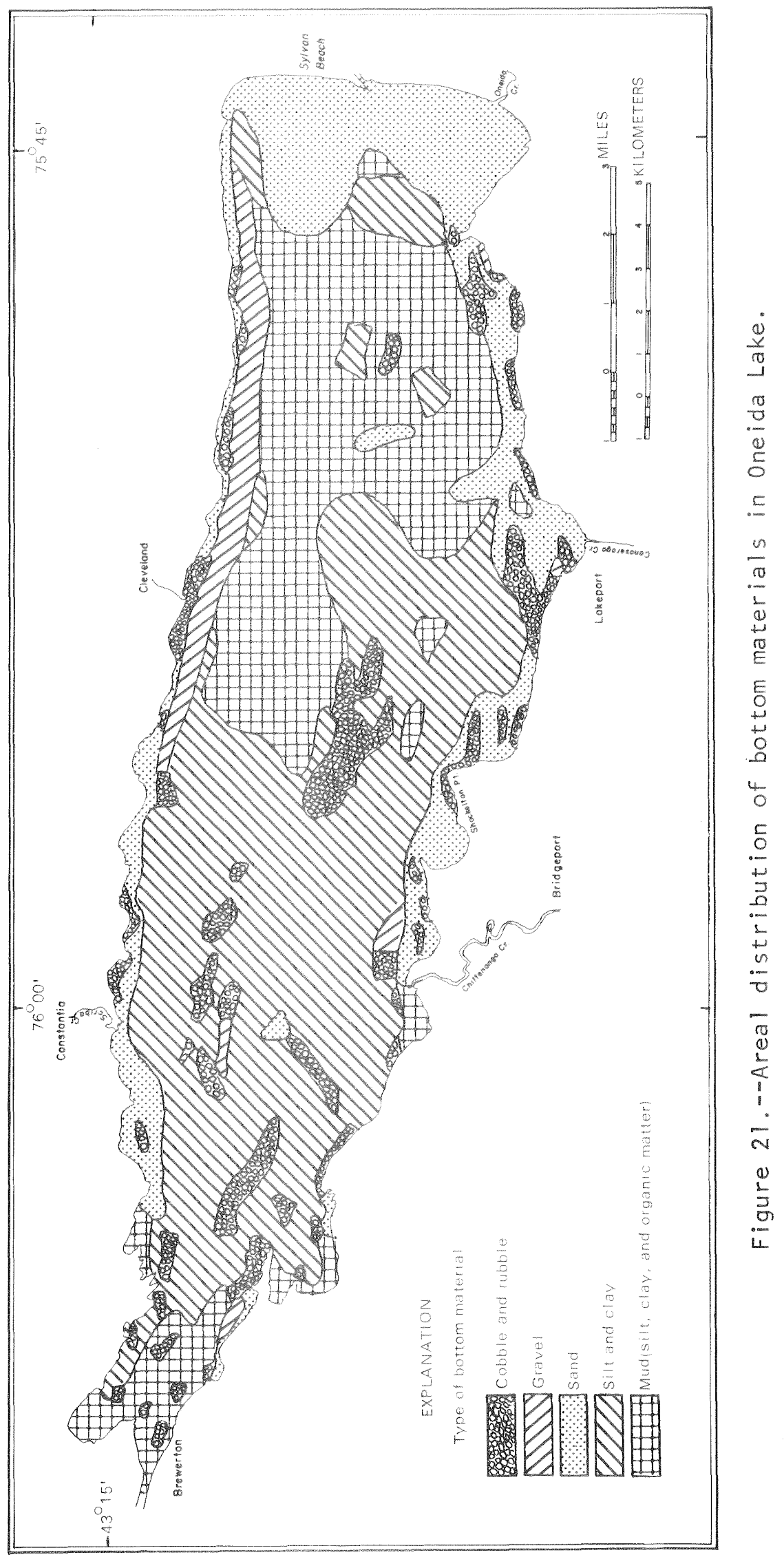




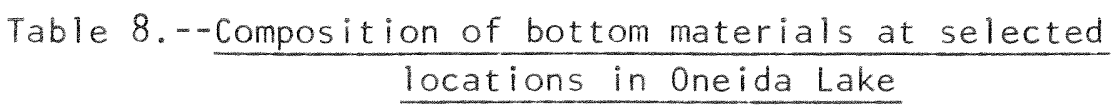

\begin{tabular}{|c|c|c|c|c|c|}
\hline \multirow[b]{2}{*}{ Location } & \multicolumn{5}{|c|}{ Type of bottom material (in percent) } \\
\hline & $\begin{array}{l}\text { Cobble } \\
\text { and } \\
\text { rubble }\end{array}$ & Gravel & Sand & $\begin{array}{l}\text { Silt } \\
\text { and } \\
\text { clay } 1\end{array}$ & Organic \\
\hline Sampling station 8 & -- & -- & 66.7 & 33.3 & 5.4 \\
\hline Sampling station 9 & - & -- & 58.0 & 42.0 & 2.4 \\
\hline Sampling station 10 & -- & -- & 51.3 & 48.7 & 8.2 \\
\hline At buoy $109-\mathrm{FIW}$ & -- & - & 2.0 & 98.0 & 10.1 \\
\hline At buoy $113-\mathrm{FlW}$ & -- & -- & 2.8 & 97.2 & 11.0 \\
\hline 150 yds north of Bushnell Point & -- & - & 93.4 & 6.6 & .9 \\
\hline Sampling station 11 & -- & $-\infty$ & 9.4 & 90.6 & 7.1 \\
\hline Sampling station 12 & - & - & 1.0 & 99.0 & 9.0 \\
\hline Sampling station 13 & -- & - & .9 & 99.1 & 11.6 \\
\hline $\begin{array}{l}200 \text { yds north of Canaseraga } \\
\text { Creek mouth }\end{array}$ & -- & -- & 70.0 & 30.0 & 6.1 \\
\hline 400 yds south of Cleveland & -- & 100 & -- & - & $-\cdots$ \\
\hline 1,000 yds south of buoy $121-\mathrm{FIW}$ & 100 & -- & -- & -- & $-\infty$ \\
\hline 200 yds east of Shackelton Point & 100 & -- & -- & - & - \\
\hline Sampling station 14 & -- & - & 27.8 & 72.2 & 5.8 \\
\hline Sampling station 15 & 100 & -- & -- & - & -- \\
\hline Sampling station 16 & $-\cdots$ & - & 2.7 & 97.3 & 9.2 \\
\hline 200 yds south of Bernhards Bay & -- & - & 82.0 & 18.0 & 1.7 \\
\hline $\begin{array}{l}200 \text { yds west of Chittenango } \\
\text { Creek mouth }\end{array}$ & - & -- & 41.1 & 58.9 & 2.6 \\
\hline Sampling station 17 & -- & - & 1.2 & 98.8 & 10.8 \\
\hline Sampling station 18 & -- & -- & 9.2 & 90.8 & 7.1 \\
\hline
\end{tabular}


Table 8.--Composition of bottom materials at selected

locations in Oneida Lake (Continued)

\begin{tabular}{|c|c|c|c|c|c|}
\hline \multirow[b]{2}{*}{ Location } & \multicolumn{5}{|c|}{ Type of bottom material (in percent) } \\
\hline & $\begin{array}{l}\text { Cobble } \\
\text { and } \\
\text { rubble }\end{array}$ & Gravel & Sand & $\begin{array}{l}\text { Silt } \\
\text { and } \\
\text { clayd }\end{array}$ & Organic \\
\hline Sampling station 19 & -- & -- & 4.6 & 95.4 & 3.4 \\
\hline 400 yds east of Dunham Island & - & -- & 38.1 & 61.9 & 3.4 \\
\hline Center of Threemile Bay & $-\cdots$ & -- & 100.0 & -- & .1 \\
\hline Sampling station 20 & - & -- & 42.1 & 57.9 & 10.7 \\
\hline 400 yds west of Frenchman IsIand & 100 & -- & -- & -- & -- \\
\hline Sampling station 21 & - & -- & 20.5 & 79.5 & 5.2 \\
\hline Sampling station 22 & - & -- & 39.6 & 60.4 & 5.4 \\
\hline
\end{tabular}

1 Includes organic fraction.

Dredging Practices

The Syracuse District Office, New York State Department of Transportation, is responsible for dredging in Oneida Lake. Periodical dredging maintains a water depth of 14 feet $(4.3$ meters) in the New York Barge Canal, which extends the length of the lake. Dredging has not been necessary since the middle of 1950 (New York Department of Transportation, written commun., 1968). Dredging spoils were placed at the entrance of Big Bay, along the shore west of Long Point and west of Dunham Island.

Oneida Lake was dredged every 5 or 6 years near sylvan Beach from 1929 to 1948. The lake was last dredged in that area in 1950. Dredgings were deposited north of the canal channel behind the breakwater, south of the channel, and occasionally in deep water. In the 1950's or early 1960's, the lake at Brewerton was dredged for construction of Interstate Highway 81.

Depth soundings are made each spring along the Barge Canal and in some tributaries flowing into the east end of Oneida Lake. The canal and the tributaries such as Fish and Wood Creeks are dredged annually wherever required. Annual dredging spoils of 350,000 to 400,000 cubic yards $(268,000$ to 306,000 cubic meters) are placed behind levees at the Rome summit. 


\section{Vertical Stratification}

A lake in the temperate zone will generally undergo seasonal variations of temperature through the water column. These variations, with accompanying thermal stratification, are perhaps the most influential factors within a lake and are the substructure upon which the entire biological framework rests.

Generally and briefly, a lake is homothermous during the spring (fig. 22). As air temperature rises, the temperature of upper layers of water also rises; and upper layers mix with lower layers. By late spring or early summer, differences in thermal resistance cause the mixing to cease and the lake approaches thermal stratification of the summer season. In this period, the warm upper layer of water (the epilimnion) is isolated from the cold lower layer (the hypolimnion) by the thermocline. When thermal stratification becomes established, the lake enters the summer stagnation period (the period when the hypolimnion becomes stagnated).

As the temperature of air decreases in the fall, the temperature of the epllimnion also decreases. Successive cooling through the thermocline to the hypolimnion results in a homothermous condition. The lake then enters the fall circulation period (sometimes referred to as the "fall turnover") and is again subjected to mixing.

Declining air temperatures and formation of an ice cover in the winter produce an inverse, but subtle, thermal stratification in which the densest water occupies the deeper parts of the lake. With the coming of spring and

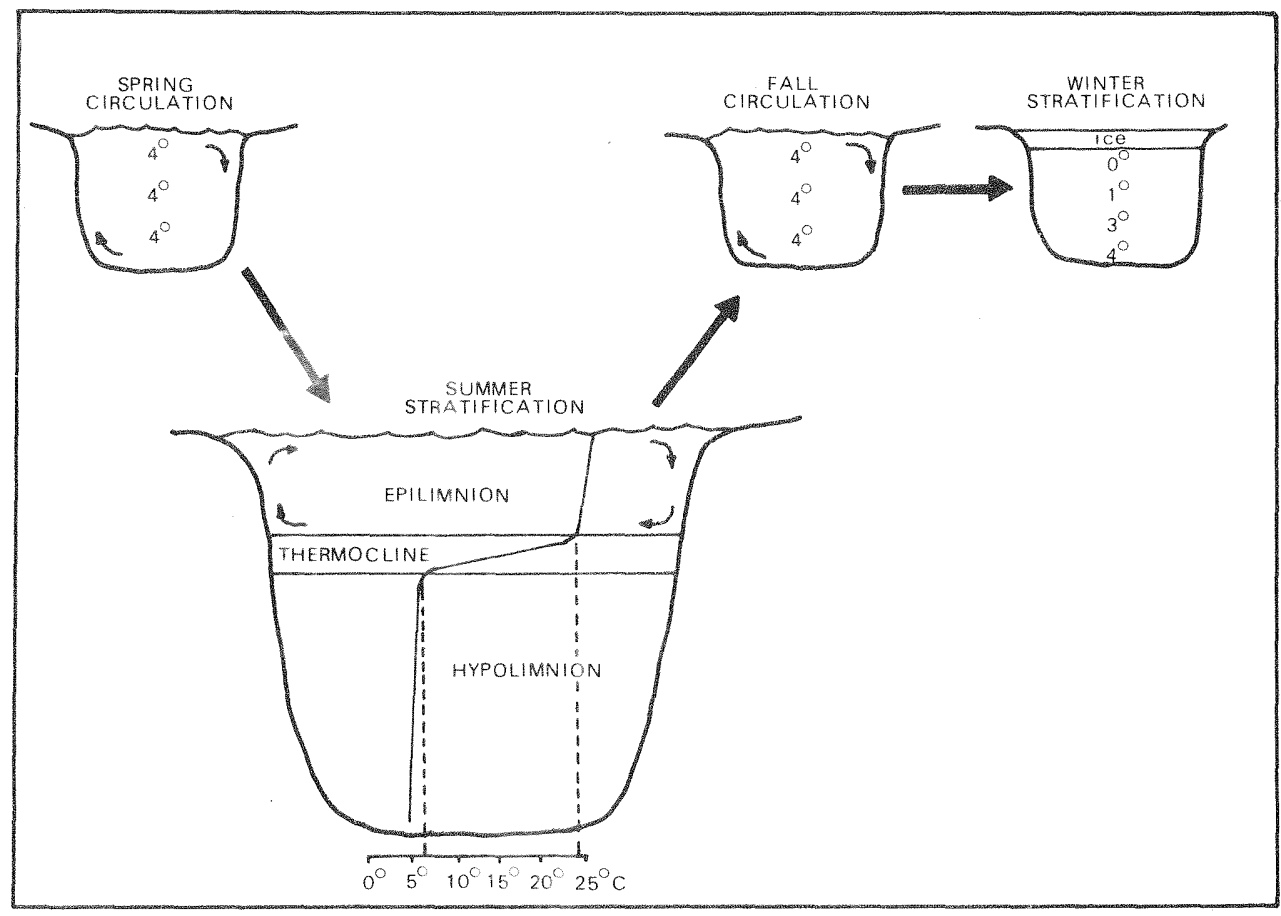

Figure 22.--Seasonal temperature variations in a temperate lake and generalized thermal stratification during the summer season (Greeson, 1969). 
gradually rising air temperatures, the ice begins to melt and the temperature of the surface water rises. The lake again becomes homothermous and spring circulation begins.

The most important phase of the thermal regime of a lake, from the standpoint of eutrophication, is the summer stagnation period. The hypolimnion, by virtue of its stagnation, becomes the zone of entrapment for inflowing materials and for decaying plant and animal matter. Because of the entrapment, less nutrients for algae are available during the critical growing season.

The hypolomnion becomes anaerobic, or devoid of oxygen, because of increased content of highly oxidizable material and separation from the atmosphere. In the absence of oxygen, conditions for chemical reduction become favorable (Hasler, 1947) and a part of the chemical constituents of the bottom materials are released into solution. During the fall circulation, nutrients are distributed through the water column for reuse during the following growing season. A continual supply of nutrients from the drainage basin, therefore, is not mandatory for sustaining continued plant production. Fruh (1967) stated that, after an initial stimulus, recycling of nutrients in a lake might be sufficient to sustain highly productive conditions for a period of years.

Oneida Lake did not thermally stratify during the summer but did exhibit near-anaerobic conditions in the lower layers of water during the the growing seasons of 1967 and 1968. Figure 23 shows that water temperature gradually declined from surface to bottom. Mean variations in vertical profiles were $4.4^{\circ} \mathrm{C}$ (Celsius) in 1967 and $3.0^{\circ} \mathrm{C}$ in 1968. Maximum variation in temperature in the growing season of 1967 was $9.9^{\circ} \mathrm{C}$ on June 13 (table 9). Maximum variation in temperature in the growing season of 1968 was $7.4^{\circ} \mathrm{C}$ on July 17 (table 10). In the fall and the spring seasons, a homothermous condition existed.

The vertical profile of temperature under ice cover had a typical, but subtle, stratification. Figure 24 shows that the coldest water was near the ice-water interface; the temperature increased with depth. The densest water, with a temperature of $4^{\circ} \mathrm{C}$, occupied the deeper parts of the lake below a depth of about 45 feet (13.7 meters).

Even though Oneida Lake did not thermally stratify, dissolved oxygen stratified sharply at an average depth of about 30 feet ( 9 meters) in the growing season of 1967 and at about 32 feet $(9.8$ meters) in the same period of 1968 (tables 9 and 10). Level of stratification was very pronounced. High dissolved-oxygen contents (as much as $18 \mathrm{mg} / 1$ ) were detected above the level of stratification, and near-anaerobic conditions existed, at times, below that level. A low dissolved-oxygen content of 0.77 milligrams per liter was measured on July 27, 1967.

Oxygen stratification generally began with the start of increased phytoplankton production and accompanying increase of oxidizable materials. Figure 25 shows the depths of stratification in the growing seasons of 1967 and 1968. Depth fluctuated with changes in phytoplankton production. The longer period of stratification in 1967 resulted from the substantially larger phytoplankton population that year. 
EXPLANATION

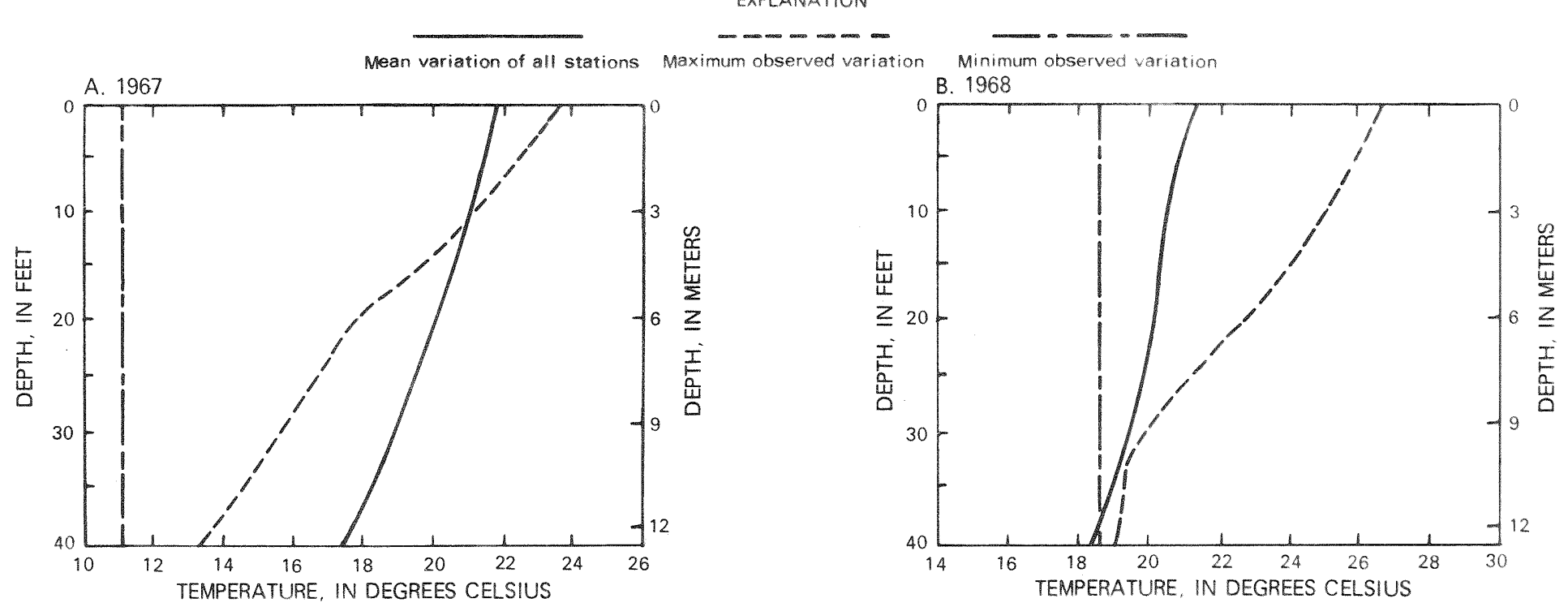

$\stackrel{+}{\circ}$
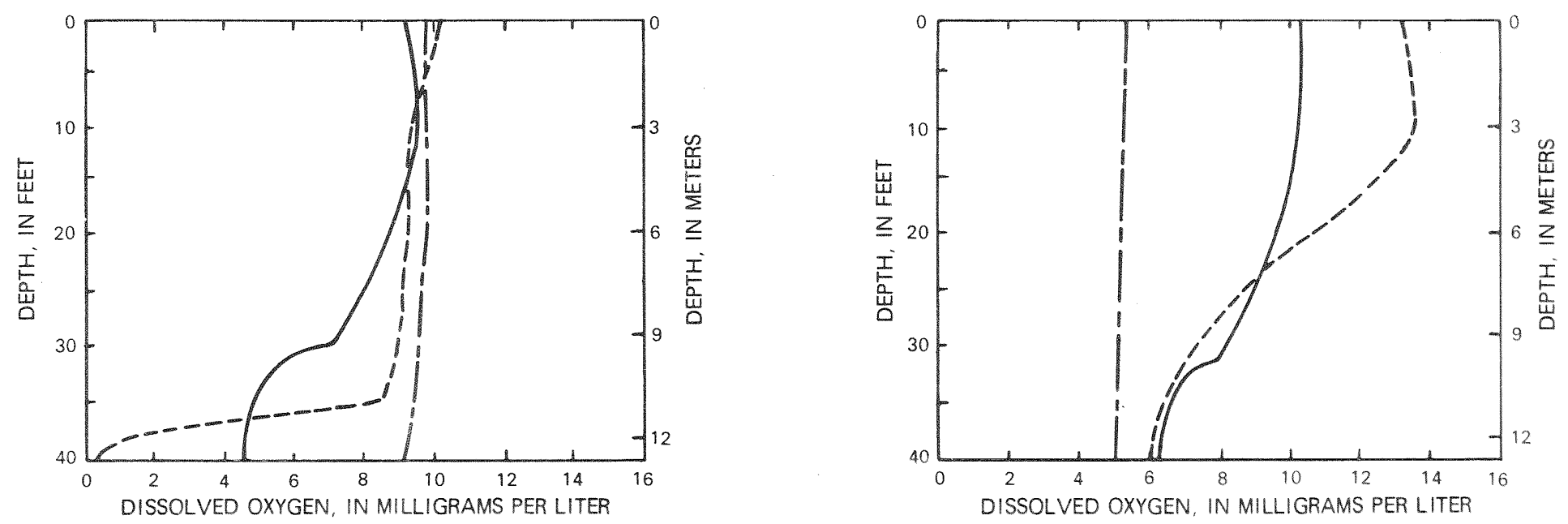

Figure 23.--Vertical profiles of water temperature and dissolved-oxygen content during the growing seasons 1967 (A) and 1968 (B). 


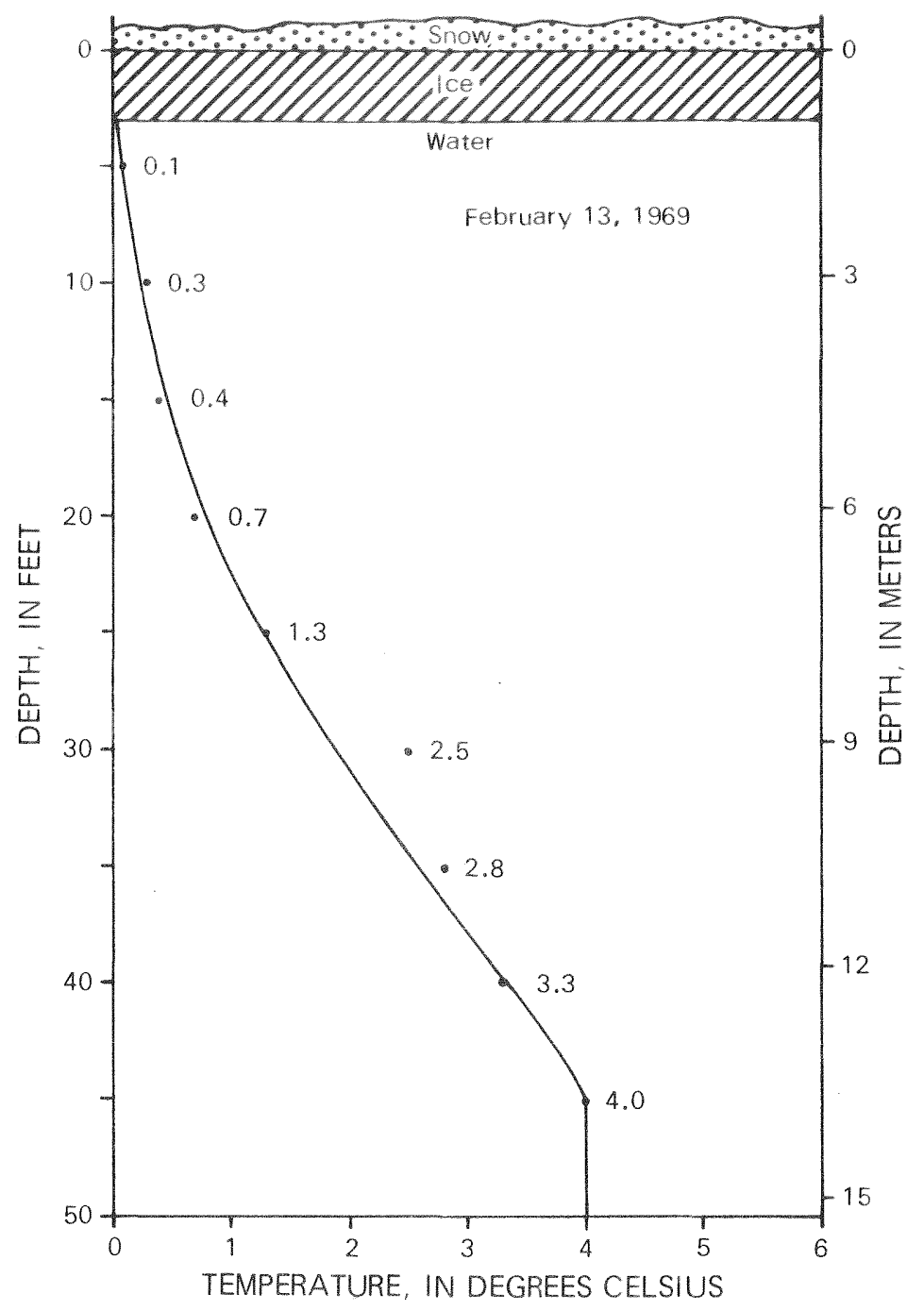

Figure 24.--Vertical profile of water temperature under ice cover. values represent mean temperatures for all seasons. 
Table 9.--Vertical profiles of water temperature and dissolved oxygen, June through October 1967

$\left({ }^{\circ} \mathrm{C}\right.$, degrees Celsius; ft, feet; mg/l, milligrams per liter; D.0., dissolved oxygen)

\begin{tabular}{|c|c|c|c|c|c|c|c|c|}
\hline $\begin{array}{l}\text { Depth } \\
(\mathrm{ft})\end{array}$ & $\begin{array}{l}\text { Temp } \\
\left({ }^{\circ} \mathrm{C}\right)\end{array}$ & $\begin{array}{c}0.0 . \\
(\mathrm{mg} / \mathrm{i})\end{array}$ & $\begin{array}{l}\text { Depth } \\
(\mathrm{ft})\end{array}$ & $\begin{array}{l}\text { Temp } \\
\left({ }^{\circ} \mathrm{C}\right)\end{array}$ & $\begin{array}{c}D .0 \\
(\mathrm{mg} / \mathrm{I})\end{array}$ & $\begin{array}{l}\text { Depth } \\
(f t)\end{array}$ & $\begin{array}{l}\text { Temp } \\
\left({ }^{\circ} \mathrm{C}\right)\end{array}$ & $\begin{array}{l}0.0 \\
(\mathrm{mg} / \mathrm{i})\end{array}$ \\
\hline \multicolumn{3}{|c|}{ June 6} & \multicolumn{3}{|c|}{ June 13} & \multicolumn{3}{|c|}{ June 20} \\
\hline 0 & 19.4 & 9.58 & 0 & 23.5 & 8.19 & 0 & 22.0 & 7.75 \\
\hline 10 & 17.5 & 9.52 & 10 & 21.1 & 8.45 & 10 & 21.4 & 7.64 \\
\hline 20 & 15.5 & 9.09 & 20 & 17.7 & 7.74 & 20 & 19.9 & 6.80 \\
\hline 30 & 13.6 & 7.64 & 30 & 15.8 & 6.46 & 30 & 16.4 & 4.29 \\
\hline 40 & 12.6 & 6.33 & 40 & 13.6 & 4.33 & 40 & 13.8 & 3.56 \\
\hline \multicolumn{3}{|c|}{ June 27} & \multicolumn{3}{|c|}{ June 30} & \multicolumn{3}{|c|}{ July 1} \\
\hline 0 & 22.4 & 9.05 & 0 & $20.8^{\prime}$ & 9.33 & 0 & 22.4 & 8.33 \\
\hline 10 & 20.8 & 8.79 & 10 & 20.8 & 9.33 & 10 & 21.5 & 8.05 \\
\hline 20 & 20.1 & 8.08 & 20 & 20.8 & 9.22 & 20 & 21.0 & 8.00 \\
\hline 30 & 18.9 & 6.63 & 30 & 20.4 & 9.19 & 30 & 21.0 & 7.81 \\
\hline 40 & 17.0 & 4.83 & 40 & 17.1 & 2.22 & 40 & 18.6 & 5.05 \\
\hline \multicolumn{3}{|c|}{ July 4} & \multicolumn{3}{|c|}{ July 10} & \multicolumn{3}{|c|}{ July 14} \\
\hline 0 & 21.6 & 9.43 & 0 & 25.2 & 9.82 & 0 & 24.3 & 7.52 \\
\hline 10 & 21.5 & 14.72 & 10 & 22.9 & 8.78 & 10 & 23.5 & 7.36 \\
\hline 20 & 21.5 & 11.17 & 20 & 22.2 & 8.12 & 20 & 22.8 & 6.22 \\
\hline 30 & 20.4 & 8.11 & 30 & 21.8 & 7.17 & 30 & 21.5 & 4.78 \\
\hline 40 & 18.9 & 6.37 & 40 & 21.0 & 4.71 & 40 & 20.4 & 3.24 \\
\hline \multicolumn{3}{|c|}{ July 18} & \multicolumn{3}{|c|}{ July 27} & \multicolumn{3}{|c|}{ August I } \\
\hline 0 & 25.1 & 9.00 & 0 & 25.0 & 9.57 & 0 & 24.8 & 8.85 \\
\hline 10 & 23.0 & 10.66 & 10 & 23.2 & 9.07 & 10 & 23.9 & 9.17 \\
\hline 20 & 23.0 & 8.21 & 20 & 22.7 & 8.12 & 20 & 23.2 & 7.66 \\
\hline 30 & 20.5 & 3.02 & 30 & 22.4 & 7.18 & 30 & 23.0 & 7.25 \\
\hline 40 & 18.3 & 1.12 & 40 & 17.6 & .77 & 40 & 21.9 & 6.77 \\
\hline \multicolumn{3}{|c|}{ August 10} & \multicolumn{3}{|c|}{ August 17} & \multicolumn{3}{|c|}{ August 22} \\
\hline 0 & 23.5 & 10.09 & 0 & 23.8 & 10.09 & 0 & 24.0 & 8.14 \\
\hline 10 & 23.5 & 9.13 & 10 & 23.0 & 9.45 & 10 & 23.0 & 8.55 \\
\hline 20 & 23.5 & 9.22 & 20 & 22.6 & 8.69 & 20 & 22.5 & 8.13 \\
\hline 30 & 23.5 & 9.13 & 30 & 22.1 & 7.89 & 30 & 22.5 & 7.57 \\
\hline 40 & 21.6 & 1.07 & 40 & 21.2 & 2.70 & 40 & 21.8 & 1.16 \\
\hline \multicolumn{3}{|c|}{ September 27} & \multicolumn{3}{|c|}{ October 9} & \multicolumn{3}{|c|}{ October 30} \\
\hline 0 & 18.1 & 9.92 & 0 & 15.8 & 9.84 & 0 & 11.0 & 10.20 \\
\hline 10 & 17.9 & 9.68 & 10 & 15.8 & 9.84 & 10 & 11.0 & 10.20 \\
\hline 20 & 17.5 & 8.97 & 20 & 15.8 & 9.84 & 20 & 11.0 & 10.00 \\
\hline 30 & 17.5 & 8.66 & 30 & 15.8 & 9.70 & 30 & 11.0 & 10.00 \\
\hline 40 & 17.2 & 7.66 & 40 & 15.8 & 9.54 & 40 & 11.0 & 9.80 \\
\hline
\end{tabular}




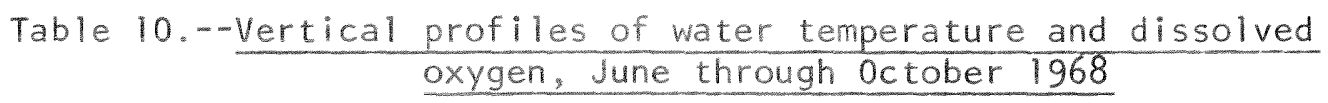
$\left({ }^{\circ} \mathrm{C}\right.$, degrees Celsius; ft, feet; mg/l, milligrams per liter; 0.0. , dissolved oxygen)

\begin{tabular}{|c|c|c|c|c|c|c|c|c|}
\hline $\begin{array}{l}\text { Depth } \\
(f t)\end{array}$ & $\begin{array}{l}\text { Temp } \\
\left({ }^{\circ} \mathrm{C}\right)\end{array}$ & $\begin{array}{c}0.0 \\
(\mathrm{mg} / \mathrm{i})\end{array}$ & $\begin{array}{l}\text { Depth } \\
(\mathrm{ft})\end{array}$ & $\begin{array}{l}\text { Temp } \\
\left({ }^{\circ} \mathrm{C}\right)\end{array}$ & $\begin{array}{c}0.0 \\
(m g / i)\end{array}$ & $\begin{array}{l}\text { Depth } \\
(f t)\end{array}$ & $\begin{array}{l}\text { Temp } \\
\left({ }^{\circ} \mathrm{C}\right)\end{array}$ & $\begin{array}{l}0.0 \\
(\mathrm{mg} / \mathrm{i})\end{array}$ \\
\hline \multicolumn{3}{|c|}{ June 5} & \multicolumn{3}{|c|}{ June 14} & \multicolumn{3}{|c|}{ July 3} \\
\hline 0 & 15.5 & 11.20 & 0 & 18.6 & 10.44 & 0 & 20.0 & 8.20 \\
\hline 10 & 15.2 & 11.20 & 10 & 18.5 & 10.60 & 10 & 19.8 & 8.10 \\
\hline 20 & 15.0 & 11.50 & 20 & 18.3 & 10.00 & 20 & 19.4 & 8.05 \\
\hline 30 & 14.5 & 10.30 & 30 & 18.1 & 9.85 & 30 & 18.2 & 6.25 \\
\hline 40 & 13.3 & 8.07 & 40 & 15.7 & 6.07 & 40 & 16.5 & 4.50 \\
\hline \multicolumn{3}{|c|}{ July 10} & \multicolumn{3}{|c|}{ July 17} & \multicolumn{3}{|c|}{ July 31} \\
\hline 0 & 22.0 & 9.22 & 0 & 26.7 & 13.10 & 0 & 21.9 & 8.43 \\
\hline 10 & 21.9 & 9.31 & 10 & 25.2 & 13.65 & 10 & 21.7 & 8.54 \\
\hline 20 & 21.2 & 9.17 & 20 & 22.8 & 10.32 & 20 & 21.7 & 8.54 \\
\hline 30 & 18.0 & 6.57 & 30 & 19.8 & 7.23 & 30 & 21.7 & 8.41 \\
\hline 40 & 17.3 & 4.48 & 40 & 19.3 & 6.02 & 40 & 20.8 & 4.10 \\
\hline \multicolumn{3}{|c|}{ August 6} & \multicolumn{3}{|c|}{ August 20} & \multicolumn{3}{|c|}{ August 28} \\
\hline 0 & 23.3 & 10.00 & 0 & 22.5 & 9.01 & 0 & 21.8 & 11.00 \\
\hline 10 & 23.0 & 10.40 & 10 & 19.0 & 8.80 & 10 & 21.8 & 10.65 \\
\hline 20 & 22.2 & 10.00 & 20 & 18.4 & 8.71 & 20 & 21.7 & 10.32 \\
\hline 30 & 22.2 & 9.12 & 30 & 18.1 & 8.46 & 30 & 21.5 & 10.05 \\
\hline 40 & 22.2 & 4.25 & 40 & 18.0 & 7.92 & 40 & 21.5 & 10.00 \\
\hline \multicolumn{3}{|c|}{ September 24} & \multicolumn{3}{|c|}{ October 3} & & & \\
\hline 0 & 21.6 & 12.05 & 0 & 18.6 & 5.27 & & & \\
\hline 10 & 21.0 & 10.80 & 10 & 18.6 & 5.27 & & & \\
\hline 20 & 20.5 & 9.80 & 20 & 18.6 & 5.18 & & & \\
\hline 30 & 19.6 & 7.42 & 30 & 18.6 & 5.18 & & & \\
\hline 40 & 19.2 & 6.04 & 40 & 18.6 & 5.15 & & & \\
\hline
\end{tabular}



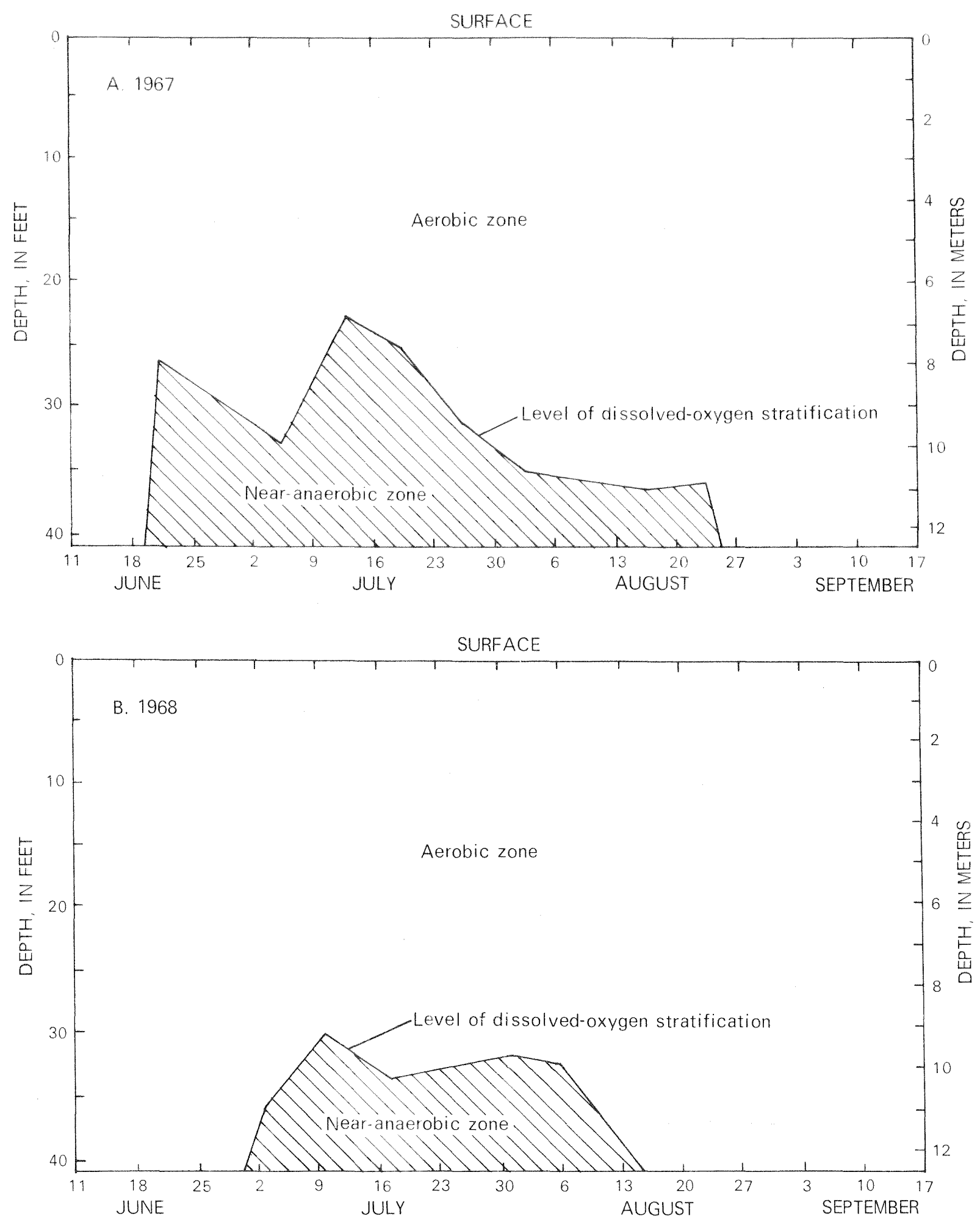

Figure 25.--Mean depth of dissolved-oxygen stratification during the growing seasons 1967 (A) and 1968 (B). 


\section{Mixing of the Water Body}

One year before this journey in 1791, a Mr. Watson of Albany took a trip through oneida Lake and thus described it: "It is exceedingly turbulent and dangerous, a small breeze producing a short bobbing sea, in consequence of its shallow waters..." (Landgraff, 1911, p. 15).

One of the principal mechanisms preventing thermal stratification in Oneida Lake and, perhaps, the single most important factor affecting chemical recycling processes of the lake is mixing of the water body. Because the long axis of the lake lies in a nearly east-west direction, Oneida Lake is constantly subjected to waves, seiches, and currents that are produced primarily by the prevailing west and northwest winds.

Data from the U.S. Weather Bureau at Hancock Field in Syracuse (U.S. Department of Commerce, 1967, 1968, and 1969) show that during calendar years 1967 and 1968, winds were from the west about 36 percent of the time and from the northwest about 24 percent of the time (fig. 26). Average wind velocity was 10.0 miles per hour ( 4.5 meters per second). In the growing seasons, June through September 1967, 1968, and 1969, west and northwest winds occurred about 57 percent of the time (fig. 27); average velocity was 7.8 miles per hour $(3.5$ meters per second). 


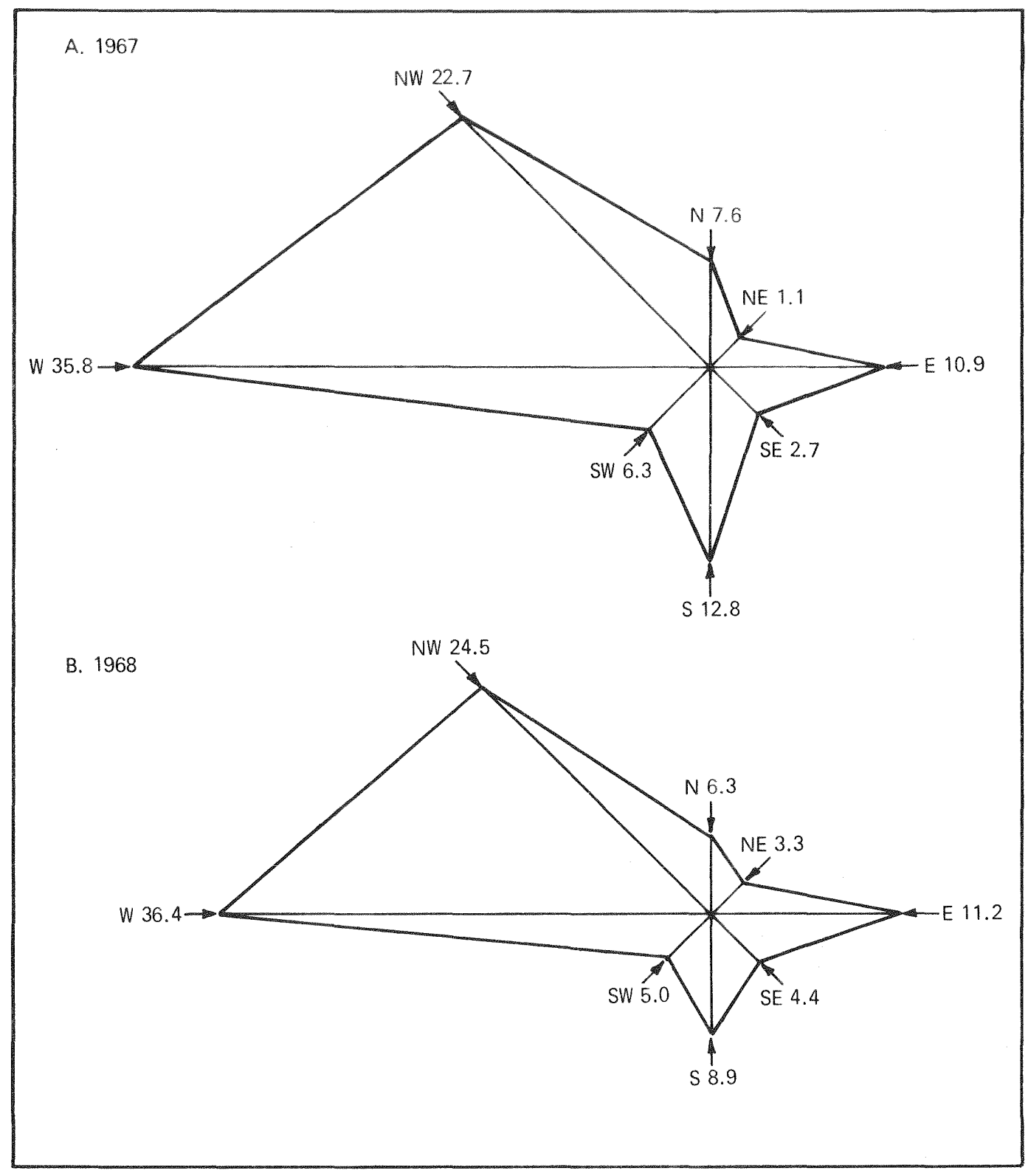

Figure 26.--Wind roses for calendar years 1967 (A) and 1968 (B), Hancock Field, Syracuse, New York, showing percentage of time that wind was recorded from each direction. (Data from U.S. Department of Commerce, 1967 and 1968.) 


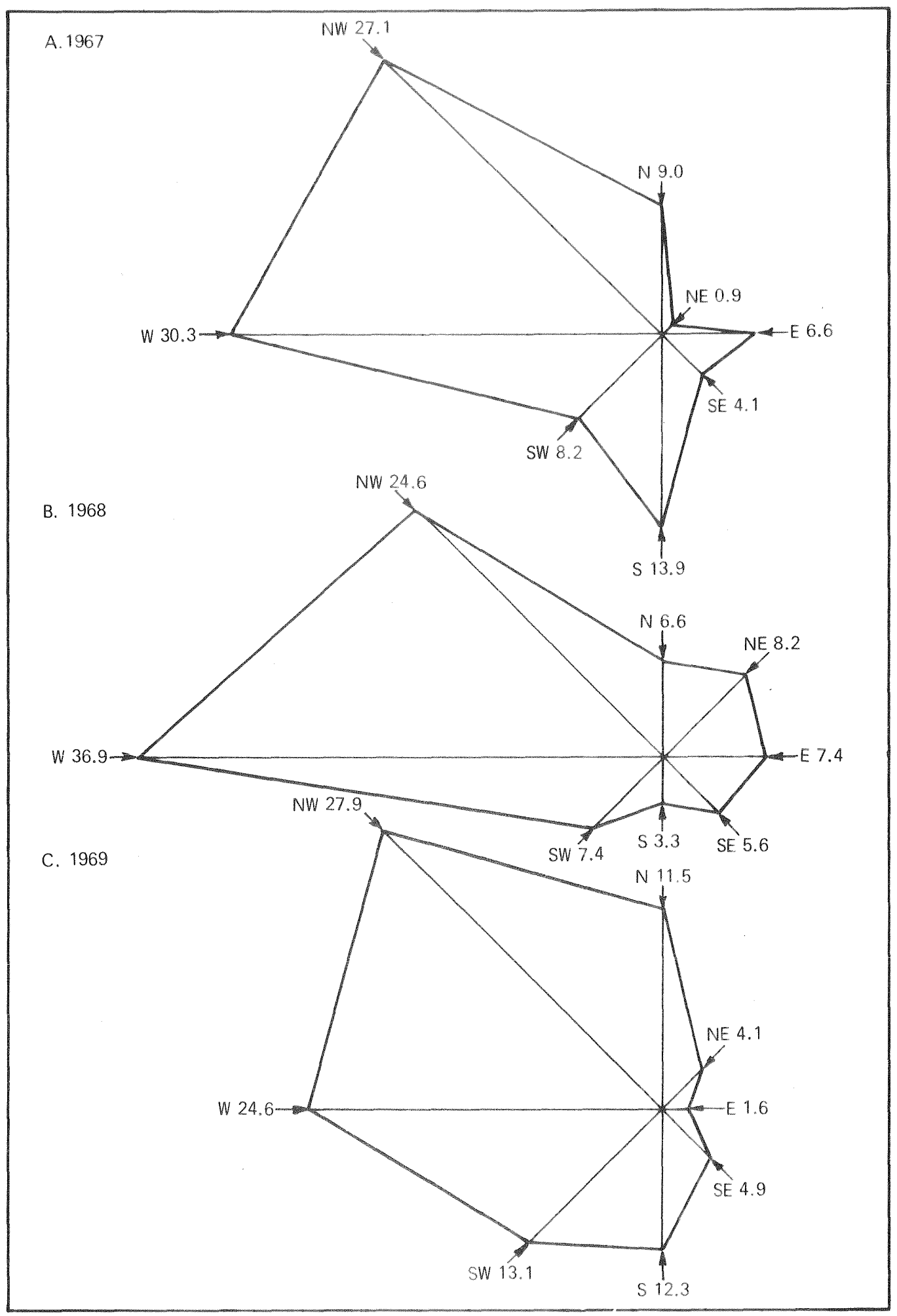

Figure 27.--Wind roses for growing seasons, June through September 1967 (A), 1968 (B), and 1969 (C), Hancock Field, Syracuse, New York, showing percentage of time that wind was recorded from each direction. (Data from U.S. Department of Commerce, 1967, 1968, and 1969.) 
When wind begins to flow over a smooth water surface, small waves are produced by the tangential force between the wind and the water. If the water is not confined by shallowness or within a small basin, waves increase in size and celerity until they move with the same velocity as the wind. Because wind forces acting on the wave are a function of the difference between wind speed and wave speed, further growth of a wave ceases when the two speeds become equal.

Actual wave height $(H)$, depending on sustained wind velocity $\left(W_{V}\right)$, in meters per second, is calculated by the formula,

$$
H=(0.26 / g)\left(W_{v}^{2}\right),
$$

where $g$ is the acceleration of gravity ( 9.809 meters per second per second) (after sverdrup and others, 1942).

According to Stevenson (1852, after Welch, 1952), maximum wave height $\left(H_{\max }\right)$, in meters, or the maximum vertical distance between crest and trough (fig. 28) is proportional to the square root of the fetch (F), in kilometers, during optimum wind conditions. The fetch is the distance from shore to the

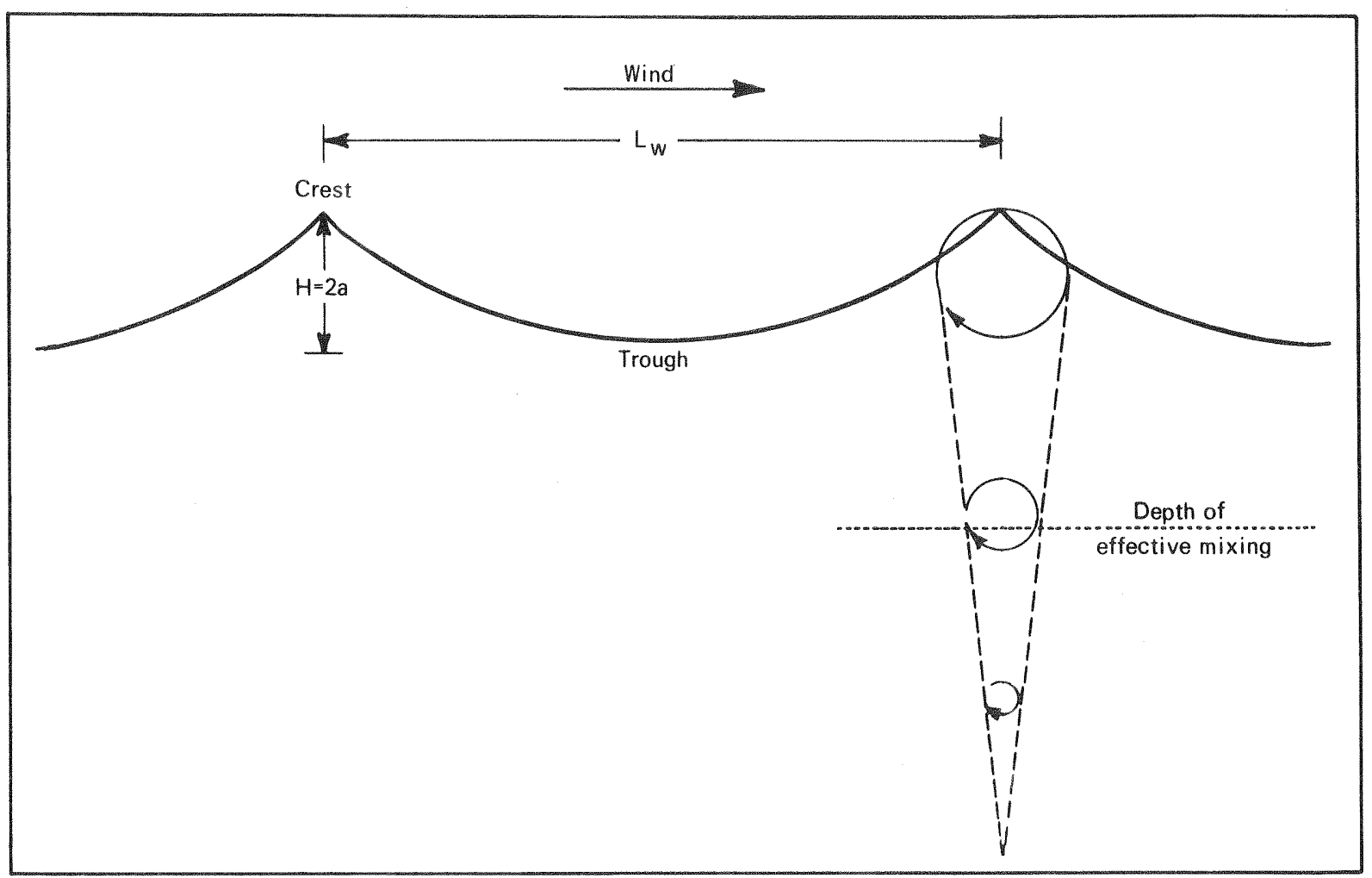

Figure 28.--Wave of oscillation and circular pattern of water movement in deep water. ( $L_{W}=$ wave length; $H=$ wave height; and $\mathrm{a}=$ wave amplitude) (from Greeson and Meyers, 1969). 
location of the wave in question and is equal to a maximum of 20 miles ( 32 kilometers) for Oneida Lake (table 1). By the formula,

$$
H_{\max }=1 / 3 \sqrt{\mathrm{F}}
$$

the maximum wave height that can theoretically occur on Oneida Lake was determined to be 6.17 feet (1.88 meters). Actual maximum wave height is slightly lower, about 6 feet (1.8 meters), because the east end of the lake consists of shallow sandy deposits.

Figure 29 shows the relationship between wave height and wind velocity and indicates that a maximum wave height on oneida Lake can be produced by a persistent west wind of about 20 miles per hour $(8.96$ meters per second). Wind velocities greater than this were recorded on 21.3 percent of the days in the growing season of $1967,22.1$ percent in the growing season of 1968, and 18.0 percent in the growing season of 1969 (U.S. Department of Commerce, 1967, 1968, and 1969).

Wave length $\left(L_{W}\right)$ is the horizontal distance from crest to crest or from trough to trough. Theoretically, the wave height may obtain one-seventh of

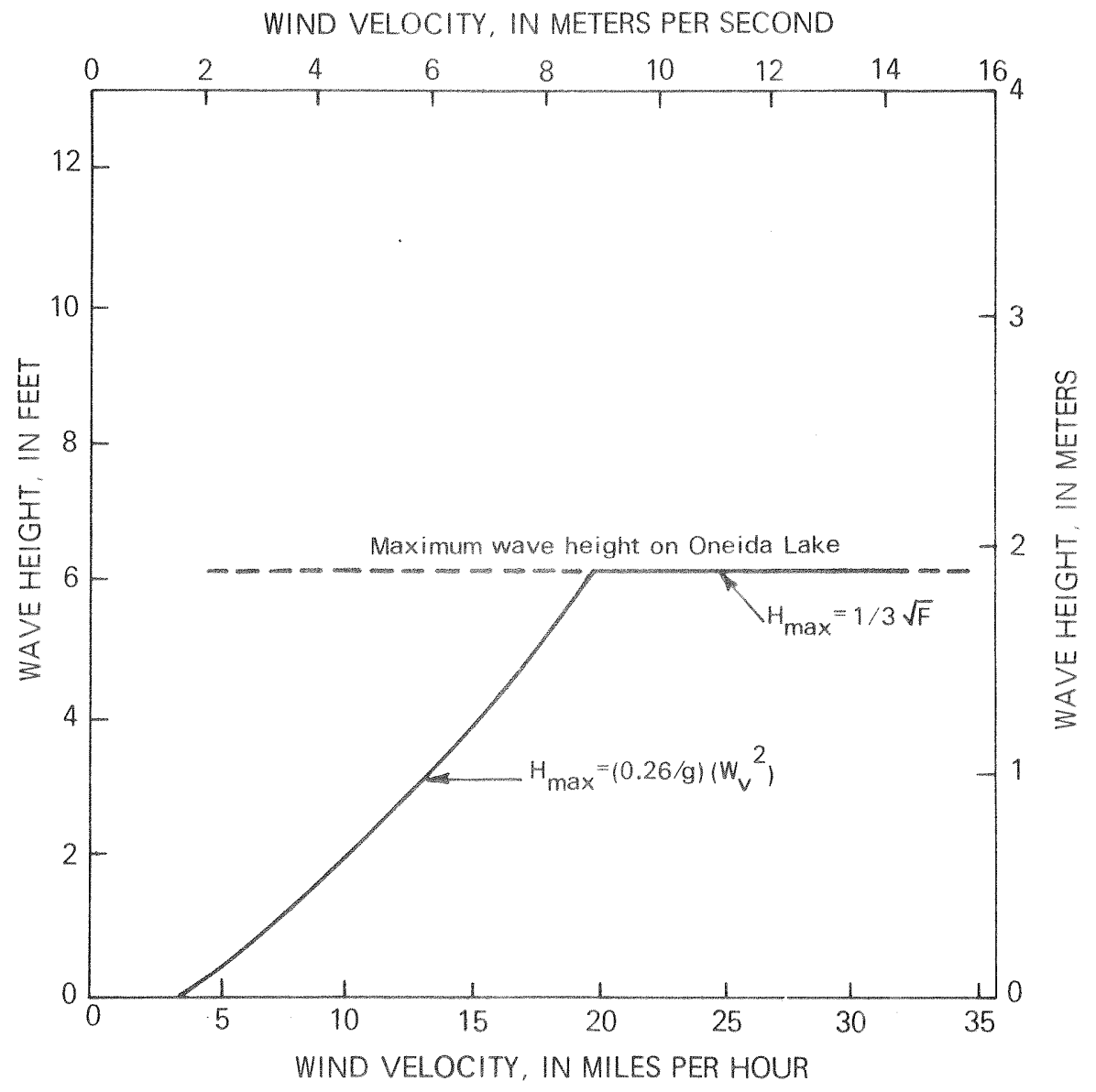

Figure 29.--Development of waves on Oneida Lake (from Greeson and Meyers, 1969). 
the wave length (Dappies, 1959); but, generally, sufficient departure from the theoretical form exists to cause the wave to collapse before the height is reached. In Oneida Lake, which is shallow and interrupted by islands and shoal areas, the wave length is shortened, and thus, waves are compacted. As a result, the theoretical ratio of wave length to wave height, probably in the order of 10 to $1\left(L_{W}: H=10: 1\right)$, is approached. A wave length of about 62 feet (18.8 meters), therefore, can accompany the maximum wave height of 6 feet ( 1.8 meters) in the open spaces of Oneida Lake.

Individual water particles within a wave are considered to revolve in circles (fig. 28). With increased depth below the surface, according to Dapples (1959), the diameter of circular motion decreases exponentially and diminishes at a depth approximately equal to the wave length. Gross (1967) states that effective mixing occurs to about one-half of this depth.

With a wave length of 62 feet ( 18.8 meters), effective mixing by wave action occurs to a depth of 31 feet ( 9.45 meters) in Oneida Lake. The significance of this depth was shown during the growing seasons when dissolved oxygen sharply stratified at an average depth of about 30 feet ( 9 meters).

Accordingly, the importance of bottom sediments and their contained chemical nutrients is greatly accentuated because 52 square miles (134 square kilometers) or 65 percent of the lake bottom is less than 30 feet ( 9 meters) in depth and can be subjected to mixing with the overlying water (fig. 30). 


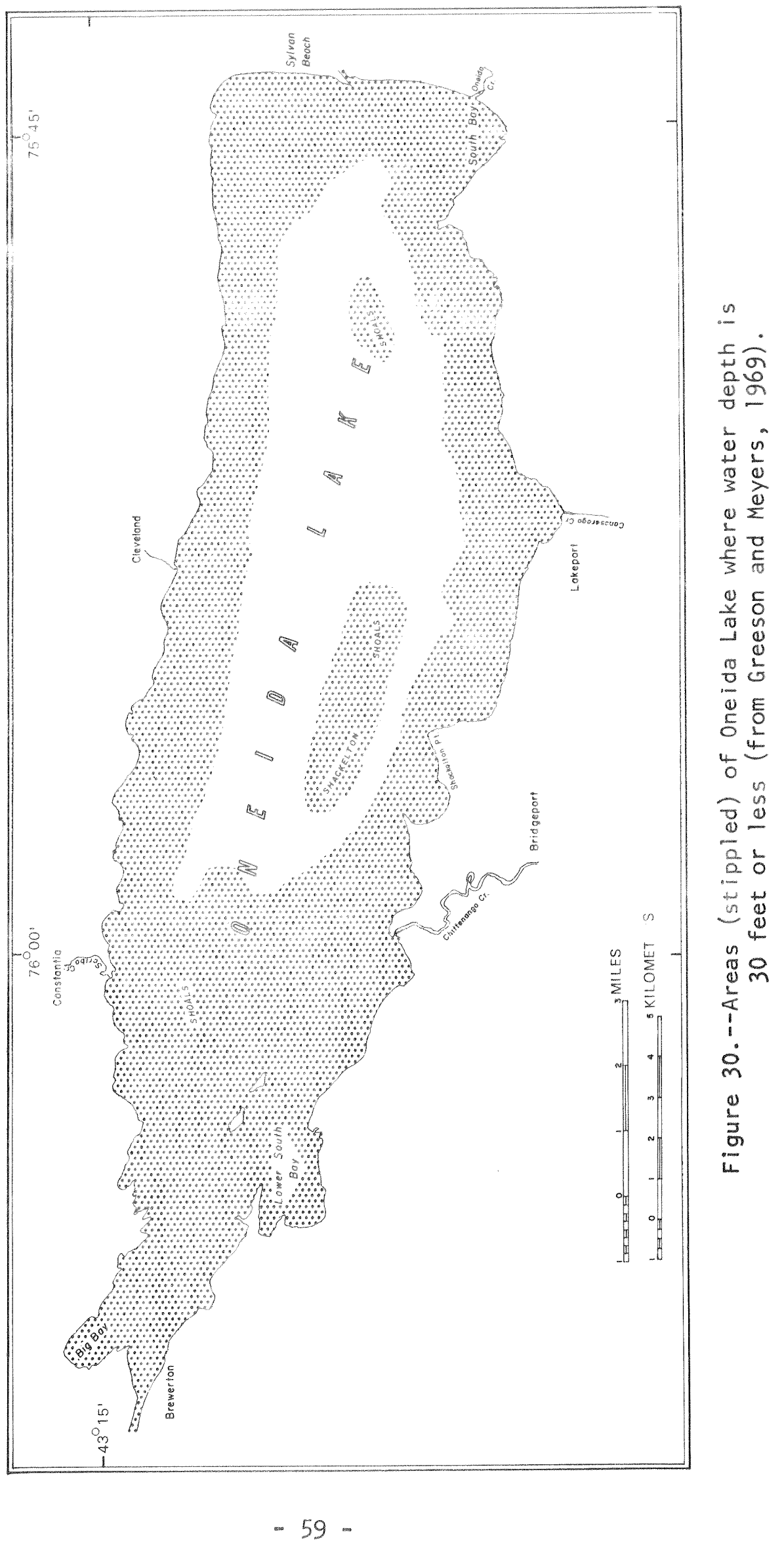




\section{Seiches}

Additional water mixing and partial horizontal transfer of materials in Oneida Lake are produced by seiches. A seiche (also called a standing wave) is the oscillation of water about one or more nodal points (fig. $3 i$ ). It is a localized and periodic shift of the water level in which the water particles advance and return in the same path rather than travel in circular motion.

A persistent west wind over Oneida Lake creates a positive displacement $\left(d^{+}\right)$of water to the east. When the inertia of the displaced water exceeds the kinetic energy of the wind or when the wind subsides, the lake surface rebounds with an alternating rise and fall. Because a seiche is an oscillating system, harmonics are formed (fig. 32).

Actual displacement of water from equilibrium (E) is the seiche amplitude (a). The range of the seiche is the maximum change in the water stage between positive and negative displacements and is equal to twice the amplitude. Amplitude and period of oscillation of a seiche rapidly decrease with cessation of wind (fig. 33).

The period of seiche oscillation ( $t$ ) is a function of the length (1) of the axis of the seiche and the mean depth (d) of water along the axis. Forel (1895, after Welch, 1952) defined the relationship as

$$
t=\frac{1}{\sqrt{d g}}
$$

where $t$ is the time of one-half oscillation and $g$ is the acceleration of gravity ( 9.809 meters per second per second).

By this formula, the period of oscillation for a uninodal longitudinal seiche in Oneida Lake was determined to be 2.4 hours. This time was confirmed by recordings at the lake outlet at Brewerton (fig. 33).

Seiches are common in Oneida Lake, and the displacement of water has exceeded 1.6 feet ( 49 centimeters) in the period of record (1964-69). Figure 34 shows that a maximum displacement occurred at Brewerton on August 16, 1966, during an east wind.

A temporary stage recorder was installed at the mouth of Oneida Creek on the east end of the lake in the growing season of 1968. Records from this recorder were compared with those from Brewerton. Figures 35 and 36 show that the largest seiches developed in Oneida Lake during west, northwest, and east winds. Positive displacement of water at Brewerton was accompanied by negative displacement at the mouth of Oneida Creek. Period of oscillation was about 2.4 hours. A typical seiche in Oneida Lake, therefore was uninodal and extended along the long axis of the lake (that is, a longitudinal seiche).

Displacement of water at Brewerton was generally larger than the displacement at the mouth of Oneida creek. This resulted from the deflection of energy by the lake shore and the constriction of the hydraulic channel at the west end of the lake. 


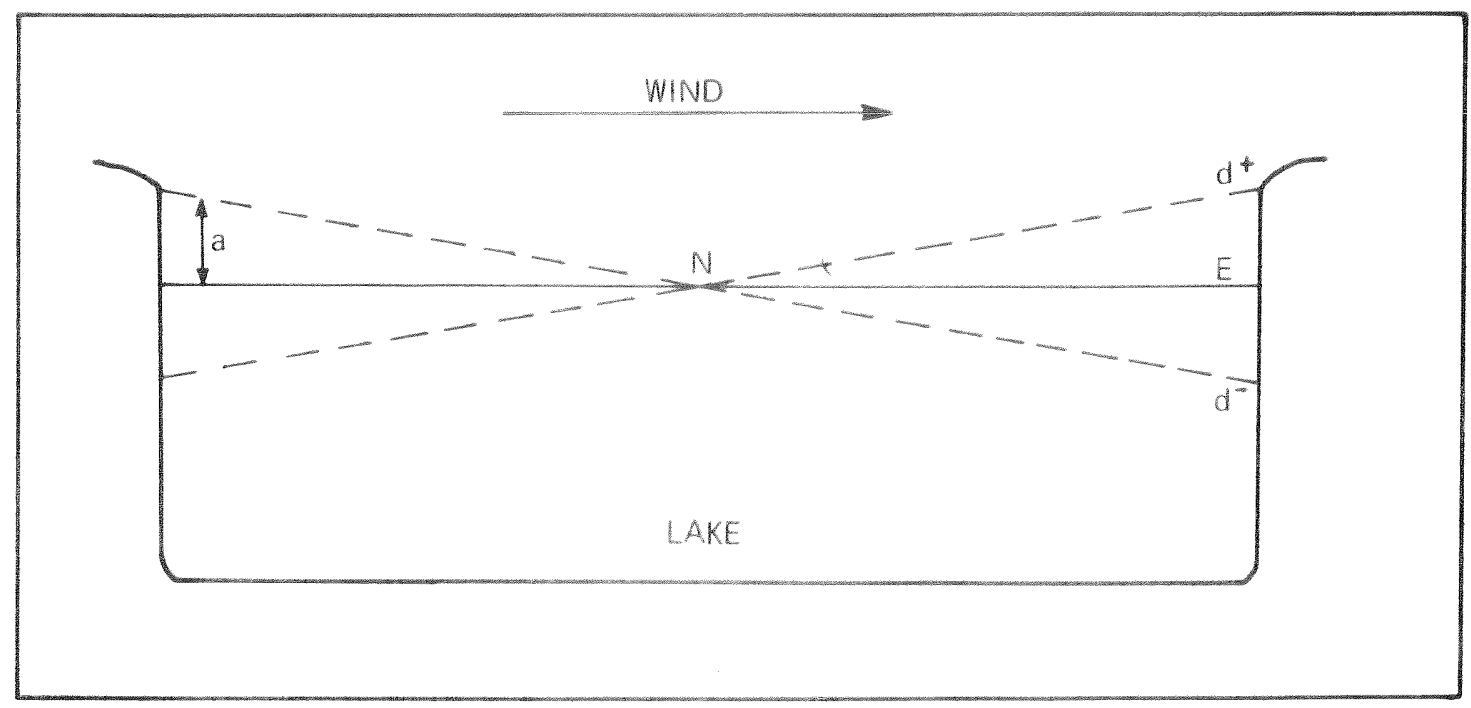

Figure 31.-- Fluctuation of the water surface in a uninodal seiche la = seiche amplitude, $N=$ nodal point, $E=$ water surface at equilibrium, and $d=$ water surface at displacement). 


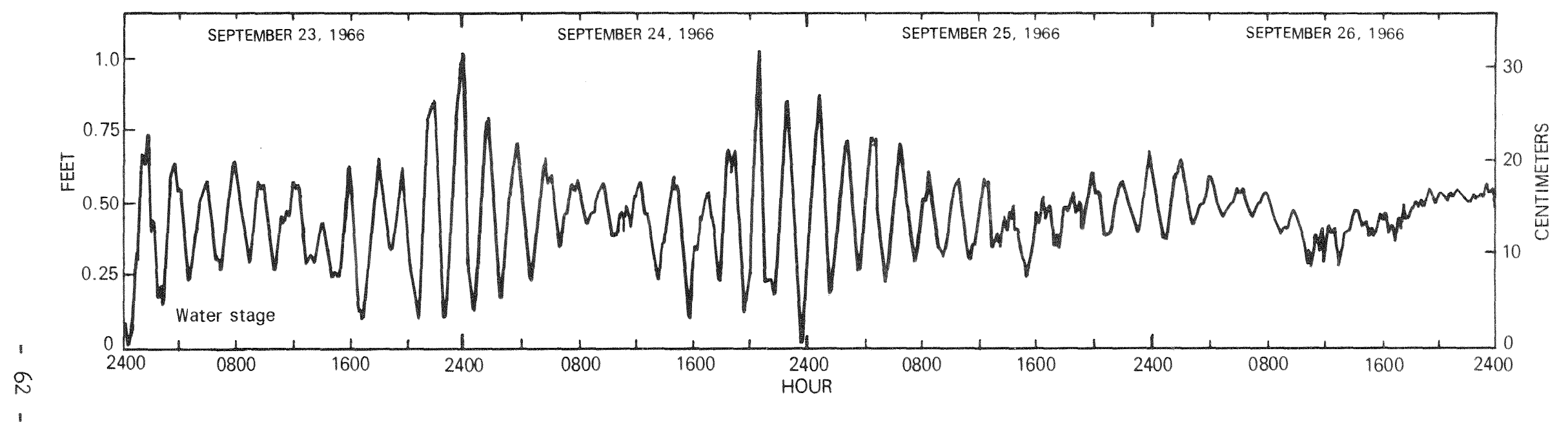

Figure 32.--Harmonic train of seiches, September 23-26, 1966. Recorded at outlet of Oneida Lake at Brewerton. 

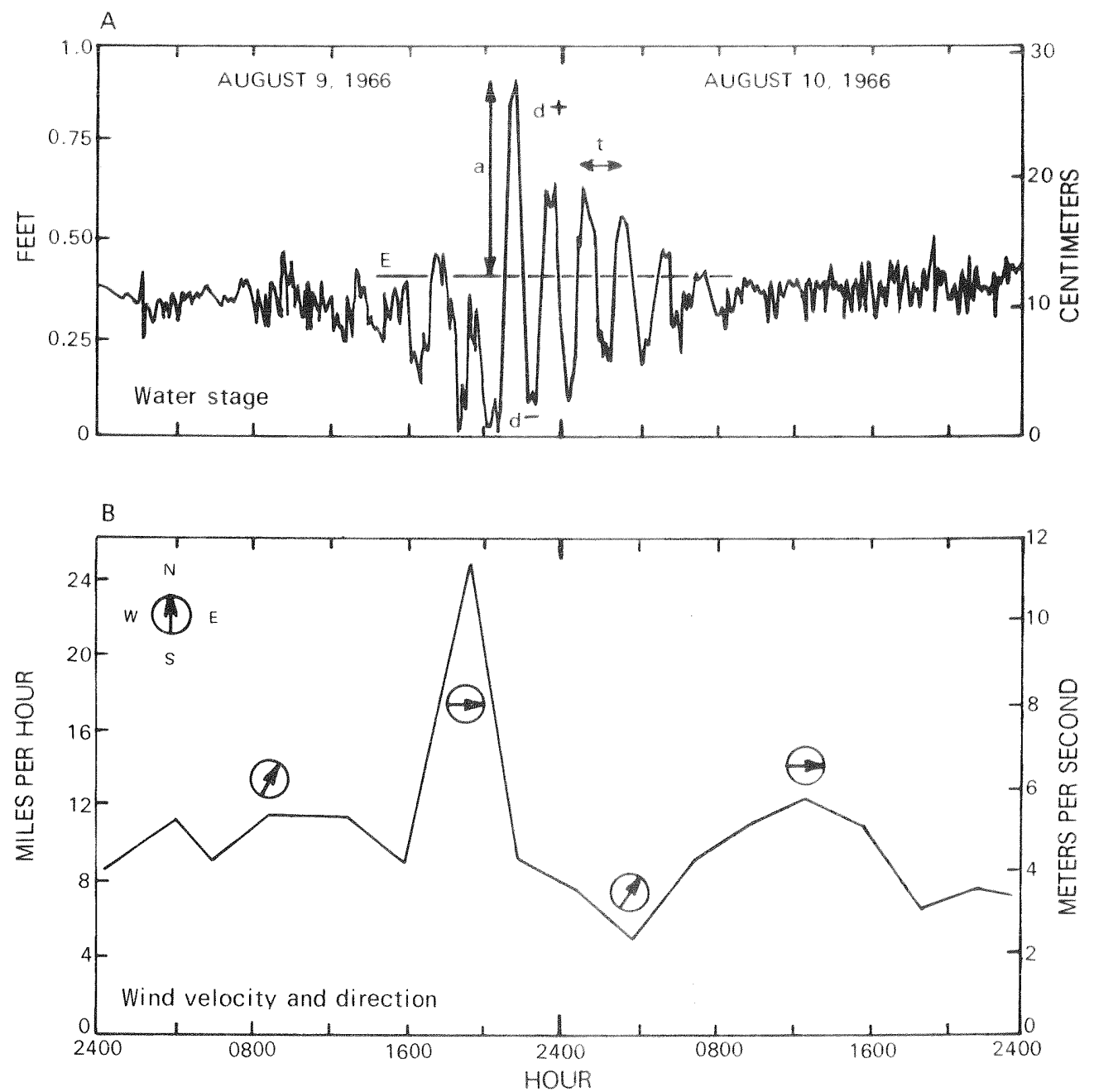

Figure 33.--mevelopment and extinction of a seiche, August 9-10, 1966. Recorded at Oneida Lake outlet at Brewerton.

A. Water stage $(E=$ water stage at equilibrium, $a=$ seiche amplitude, $d=$ water stage at displacement, $t=$ period of oscillation).

B. Wind velocity and wind direction as indicated by arrows. 

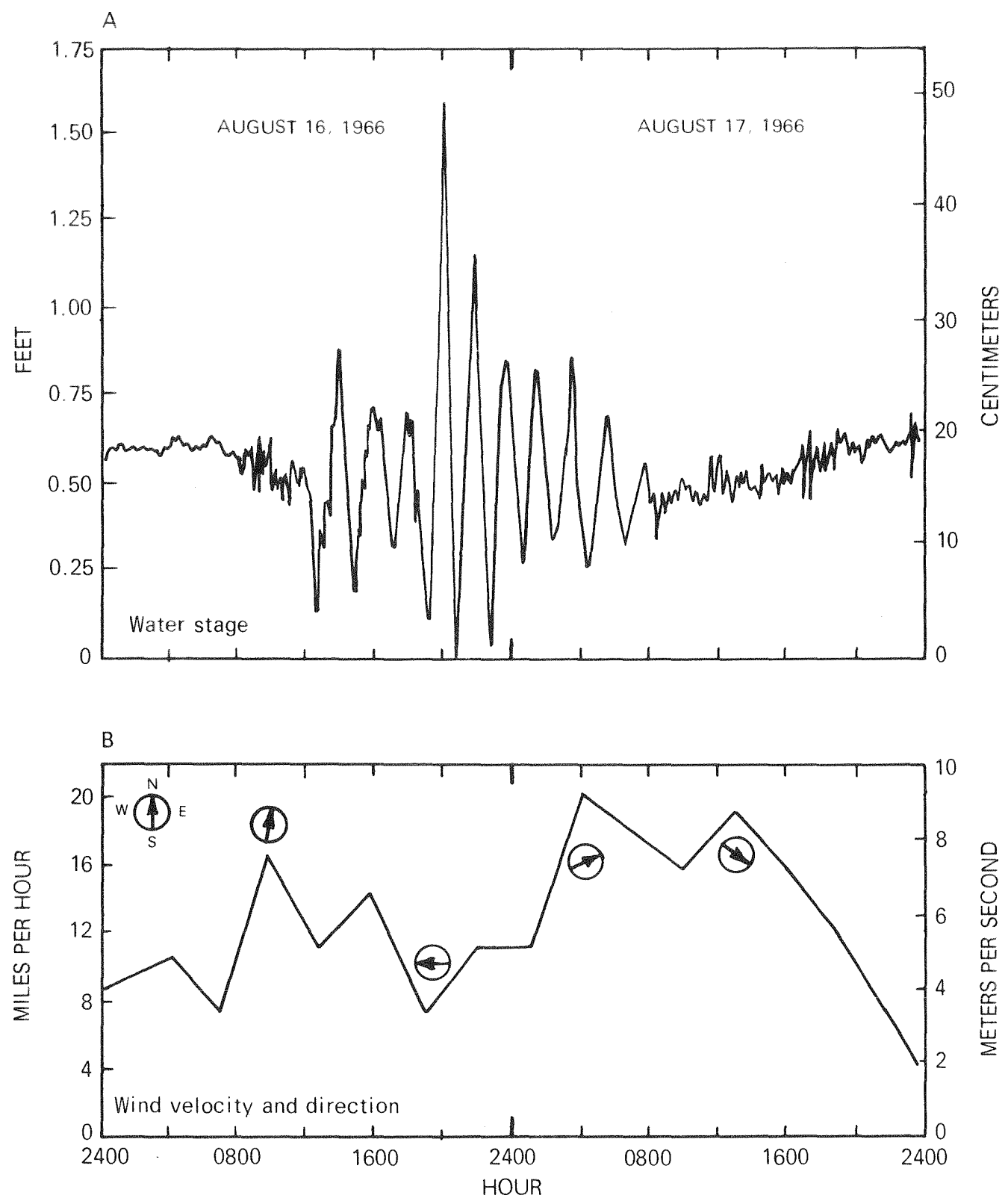

Figure 34.--Development of seiche, August 16-17, 1966. Recorded at Oneida Lake outlet at Brewerton. A. Water stage.

B. Wind velocity and wind direction as indicated by arrows. 

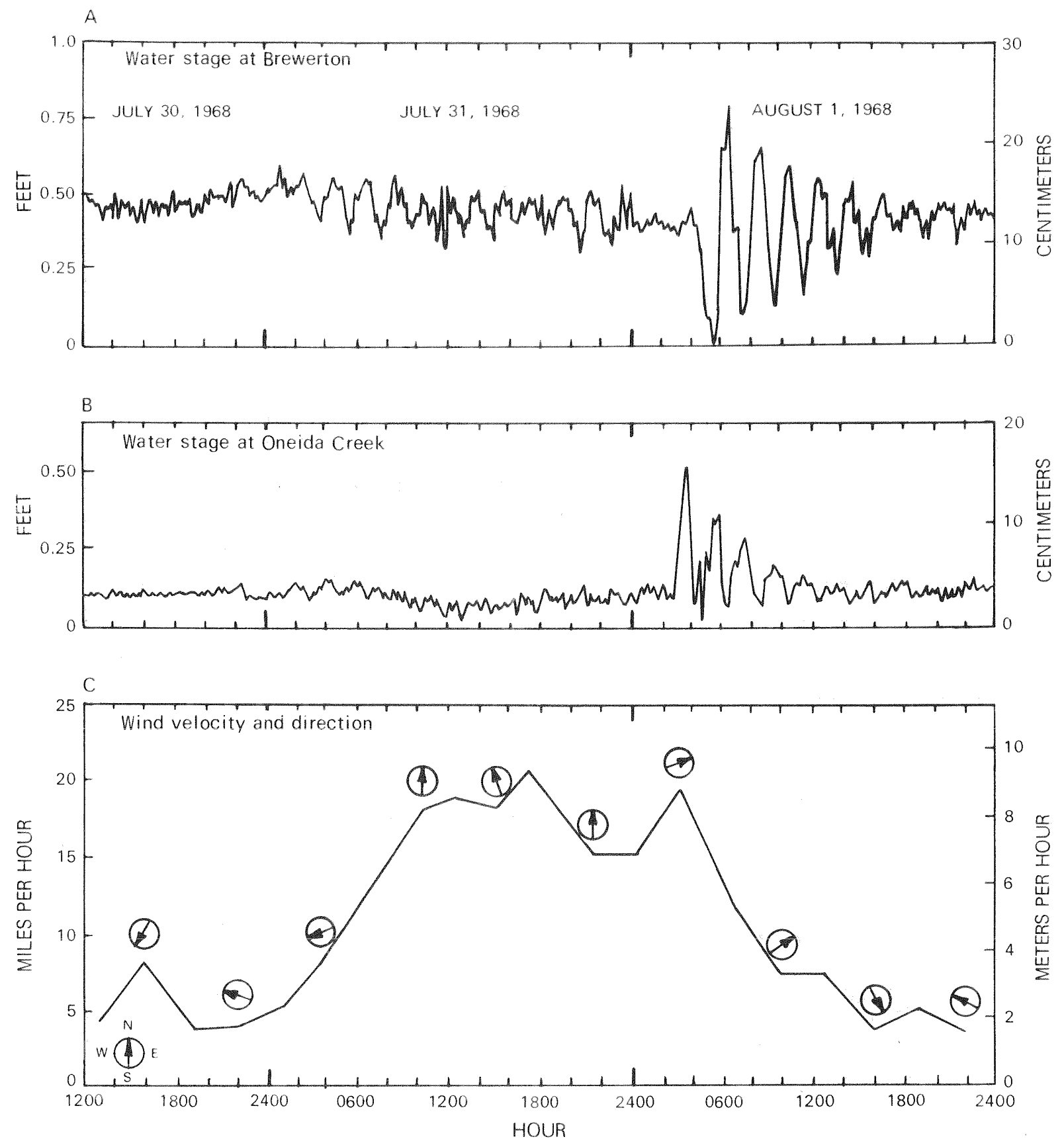

Figure 35.--Development of seiche in Oneida Lake, July 30-August 1, 1968.

A. Water stage at Brewerton.

B. Water stage at mouth of Oneida Creek.

C. Wind velocity and wind direction as indicated by arrows. 

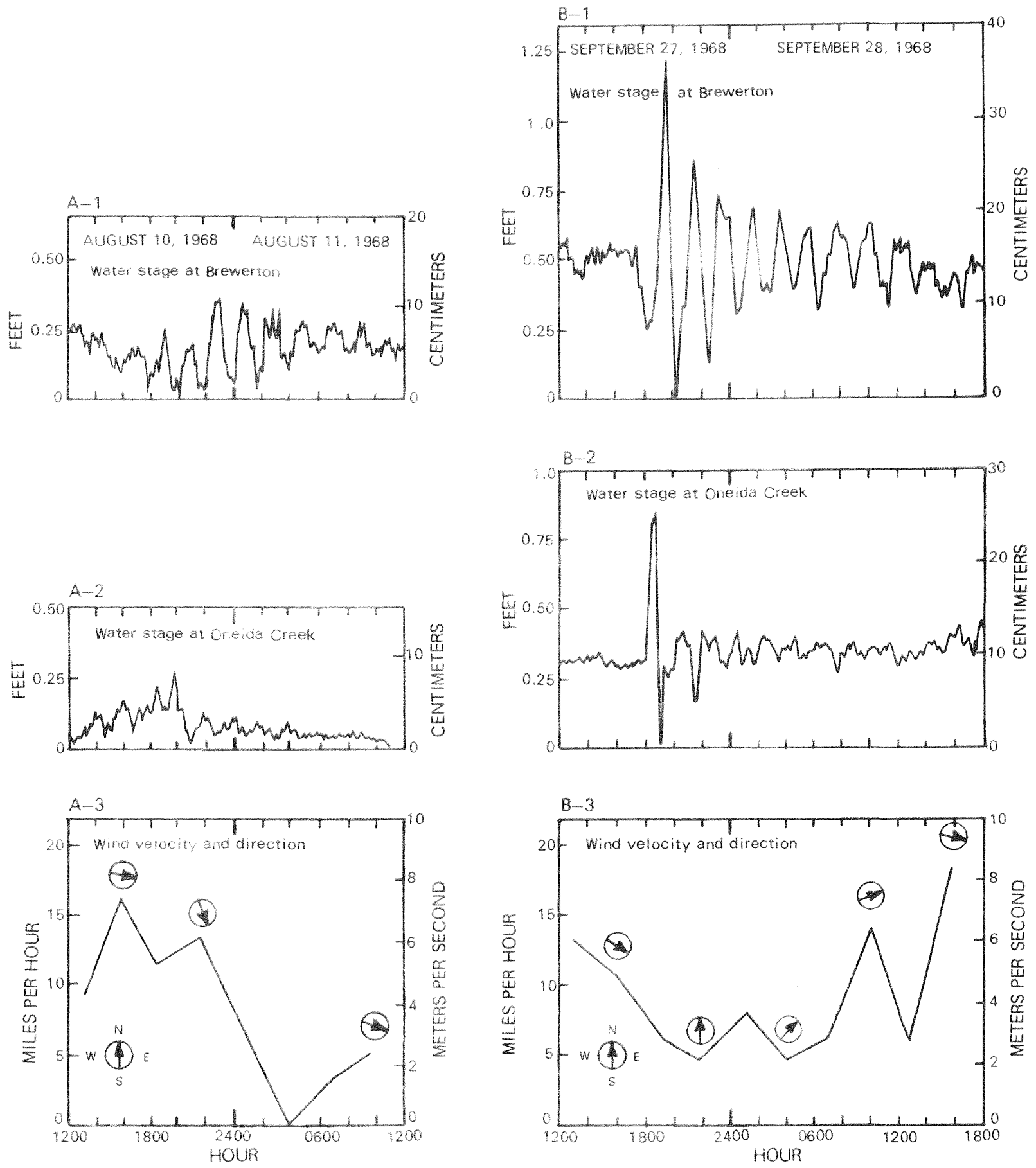

Figure 36.--Development of seiches in Oneida Lake, (A) August 10-11, 1968, and (B) september $27-28,1968$.

1. Water stage at Brewerton.

2. Water stage at mouth of Oneida creck.

3. Wind velocity and wind direction as indicated by arrows. 


\section{currents}

Water currents in Oneida Lake were measured by Houde (1968) in springs and summers of 1965-67. Houde measured surface currents with drift cards described by 01 son (1951). Subsurface currents were determined with drouges (drift crosses) and a Savonius rotor-type current meter.

Observations of Houde are summarized as follows:

Surface currents usually moved in the direction of the prevailing winds. No current patterns independent of wind direction were observed. Swiftest surface currents, as great as 0.43 feet per second $(13.0$ centimeters per second), were associated with sustained moderate winds of a velocity of $5-10$ miles per hour $(2.2-4.5$ meters per second).

Subsurface currents in bays were modified into weak eddies at depths below 6.7 feet $(2$ meters) during west winds. Generally, greater currents near the bay centers averaged about 0.23 feet per second $(7.0$ centimeters per second).

Houde (1968) often detected strong currents below 6.7 feet ( 2 meters) in the open lake at depths more than half the distance to the bottom. Current directions were opposite wind directions or were consistently toward the west when winds were from the west. Velocities were occasionally as great as 0.39 feet per second $(11.8$ centimeters per second).

\section{Langmuir Vortices}

The Onondaga Indians, one of the Five Nations of the Iroquois, called Oneida Lake, Seughka, which means "striped with blue and white lines diverging and coming together again." Landgraff (1911) stated, "at particular times its surface presents blue and white lines distinctly traceable from its head to its outlet."

The phenomenon of streaking (and mixing) is very common in Oneida Lake. Mechanisms of the process are known as Langmuir vortices. Langmuir (1938) observed in Lake George, New York, that the wind drift of surface water had definite structures. The structures formed a series of parallel helices, alternating clockwise and counterclockwise along the long axis of the wind. The surface of a lake, therefore, can be marked by linear convergences of leaves, oil films, debris, and foam. These convergences are called "wind streaks."

Langmuir found that a wind velocity of 13.4 miles per hour $(6.0$ meters per second) would produce streaks at intervals of about 82 feet (25 meters). Downward velocity of water under these conditions approached 0.08 feet per second $(2.3$ centimeters per second). Hutchinson (1957) indicated that helices become less definite with depth but serve to transfer momentum from the surface through the freely circulating part of the lake.

Even though Langmuir vortices were never quantified in this study, they were observed on many occasions. The most pronounced streaking on Oneida 
Lake occurred with moderate west winds when wave height equaled 1-2 feet (0.3-0.6 meters). Such conditions would accompany maximum surface currents reported by Houde (1968).

Figure 37 illustrates wind streaks on oneida Lake. The photograph was taken at 1020 hours on September 23, 1967, when wind was from the west at a sustained velocity of about 11.5 miles per hour ( 5.1 meters per second). The interval of streaking was about 73 feet (22 meters).
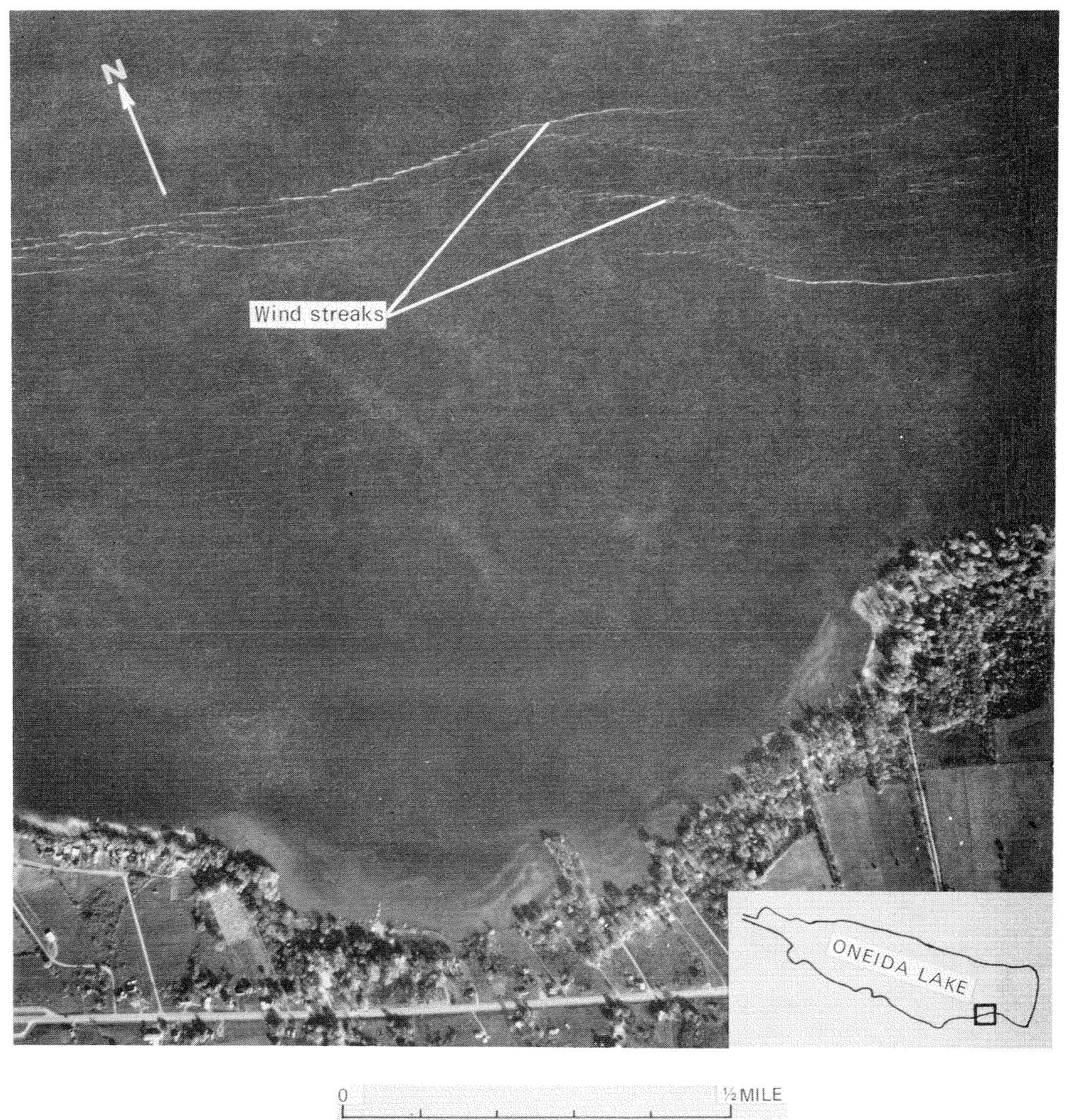

Figure 37.--Wind streaks on Oneida Lake, September 23, 1967. (Photograph courtesy of Reconnaissance Branch, Rome Air Development Center, Griffiss Air Force Base, New York.) 
Ice Cover

Ice began to form on Oneida Lake about mid-December of each study year and remained until the spring surface-water runoff. Ice breakup was relatively fast ( $5-7$ days) and generally occurred during the first week of April.

Formation of ice cover started in bay areas and along the shore and, subsequently, extended across the lake as the shallow water rapidly cooled. An ice cover over the entire lake had formed by late December and a thickness of about 1 foot $(0.3$ meter) was common in early to mid-January. Additional ice buildup resulted primarily from frozen precipitation on the ice surface. lce thicknesses of 3 feet $(0.9$ meter) or more during late March were common.

Ice cover confined the water of the lake for about 4 months each year and isolated it from wind-mixing processes. In that period, inflowing water from tributaries remained more or less as homogeneous water masses.

Displacement of lake water by tributary water continued through the winter. Strong currents were occasionally produced by the displacement and by partial mixing of water masses as amount of inflow fluctuated.

By late March, before the ice breakup, water masses were distinct bebecause of differences in their water chemistry (fig. 38). Ice-free conditions during April resulted in total mixing of the lake water. 


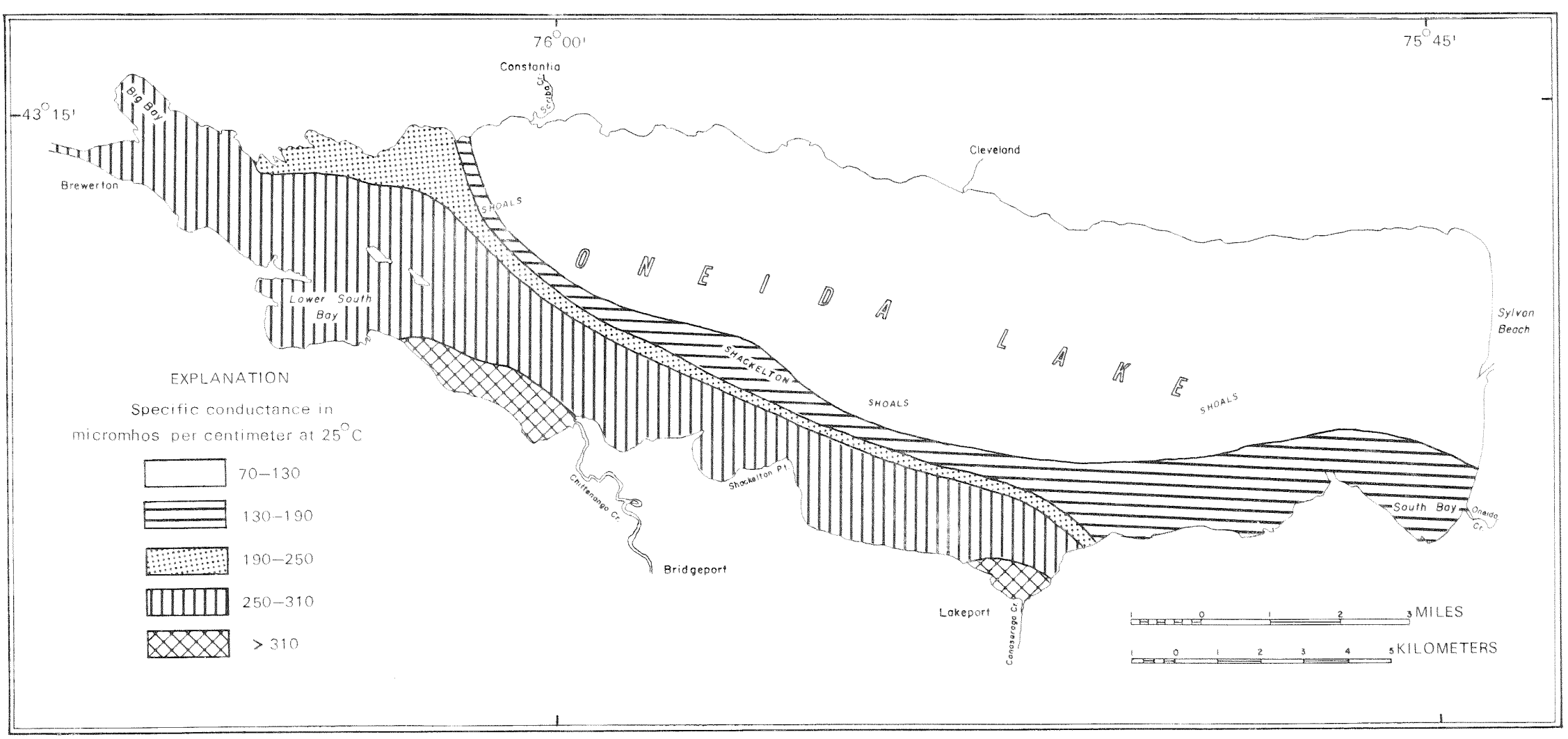

Figure 38.--Generalized location of water masses under ice cover, late March. Distribution indicated by specific conductance. 


\section{Light (Solar Radiation)}

Light is a key factor in the extent and the rate of biological production in a lake. Solar radiation is the basic source of energy for photosynthesis and primary production and, thus, a highly critical factor in all biological processes. Because of this fundamental role, light can influence the size of an aquatic community and the vertical and the horizontal distribof the organisms.

Extent of illumination in a lake depends on Several factors. Incident radiation, one of the factors, is influenced by season, time of day, and cloud cover. The degree to which light penetrates water is determined by angle of contact of light with the water surface and dissolved and suspended materials in the water. Other conditions being favorable, the greatest illumination in a lake in the northern latitudes should occur on June 21 (the summer solstice).

Figure 39A illustrates possible duration of daylight and amount of solar radiation available at the latitude of Oneida Lake. Figures 39B-D indicate weekly mean values of sunlight over the lake from May through November 196769. The period in 1969 received 54 percent of possible sunlight as compared with 51 percent in 1967 and 50 percent in 1968. Values were derived from data of the U.S. Department of Commerce (1967, 1968, and 1969) and from Per1 (1935).

Transmission of light through a column of water has been determined customarily with a Secchi disc first used by A. Secchi in 1865 (Cialdi, 1866 after Hutchinson, 1957) according to the method of Juday and Birge (1933). Even though the Secchi disc transparency is not an actual quantitative indication of light transmission, it serves as an index and a means of comparison of similar bodies of water or of the same body of water at different times or under different conditions.

Muenscher (1928) measured the Secchi disc transparency of Oneida Lake four times in June through August 1927. The mean value of his readings was 11.5 feet ( 3.5 meters). The values ranged from 9.5 feet $(2.9$ meters) to 13.5 feet $(4.1$ meters).

In the present study, Secchi disc transparency of Oneida Lake was determined during approximately 60 visits to stations 12 and 21 a. The average reading was 5.86 feet ( 1.79 meters). Table 11 indicates that greater depths were recorded at station 12 and lesser depths were observed at station 21. The mean Secchi disc transparencies at these two stations were 6.41 feet (1.95 meters) and 5.24 feet (1.60 meters), respectively.

Secchi disc transparency in Oneida Lake has apparently decreased since the measurements by Muenscher (1928). The difference in mean values between the two periods, 1927 and 1967-69, was about 5.6 feet (1.7 meters). Because the conditions under which the Secchi disc transparency is determined greatly influence the results, a single or few measurements can imply erroneous conditions. For example, the maximum Secchi disc transparency in this study was 14.10 feet $(4.40$ meters) at station 12 on June 14,1968 . The minimum value was 1.32 feet $(0.40$ meter) at the same station on August 14,1969 . 

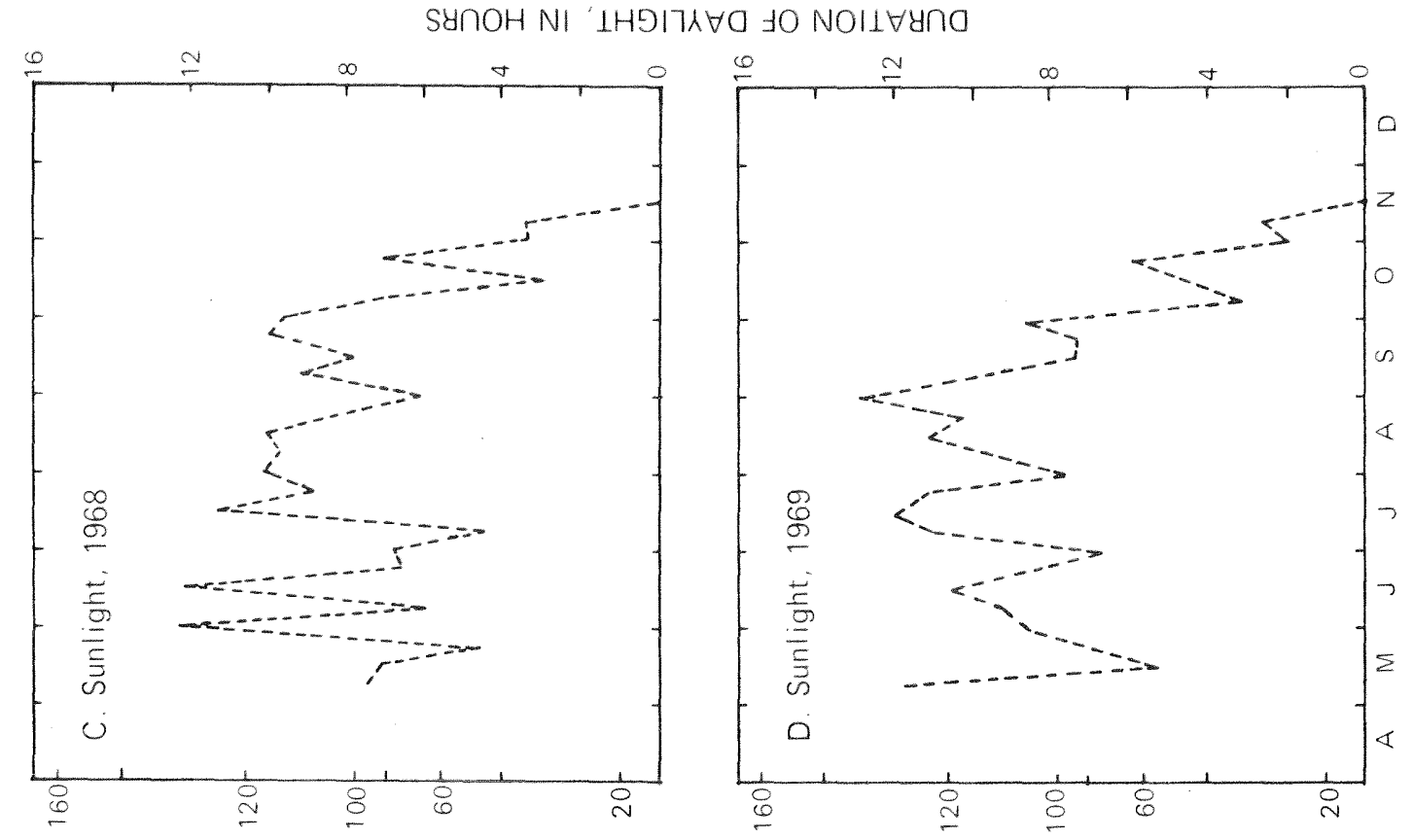

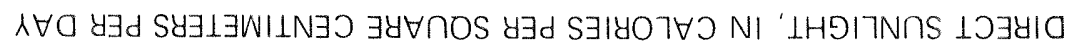
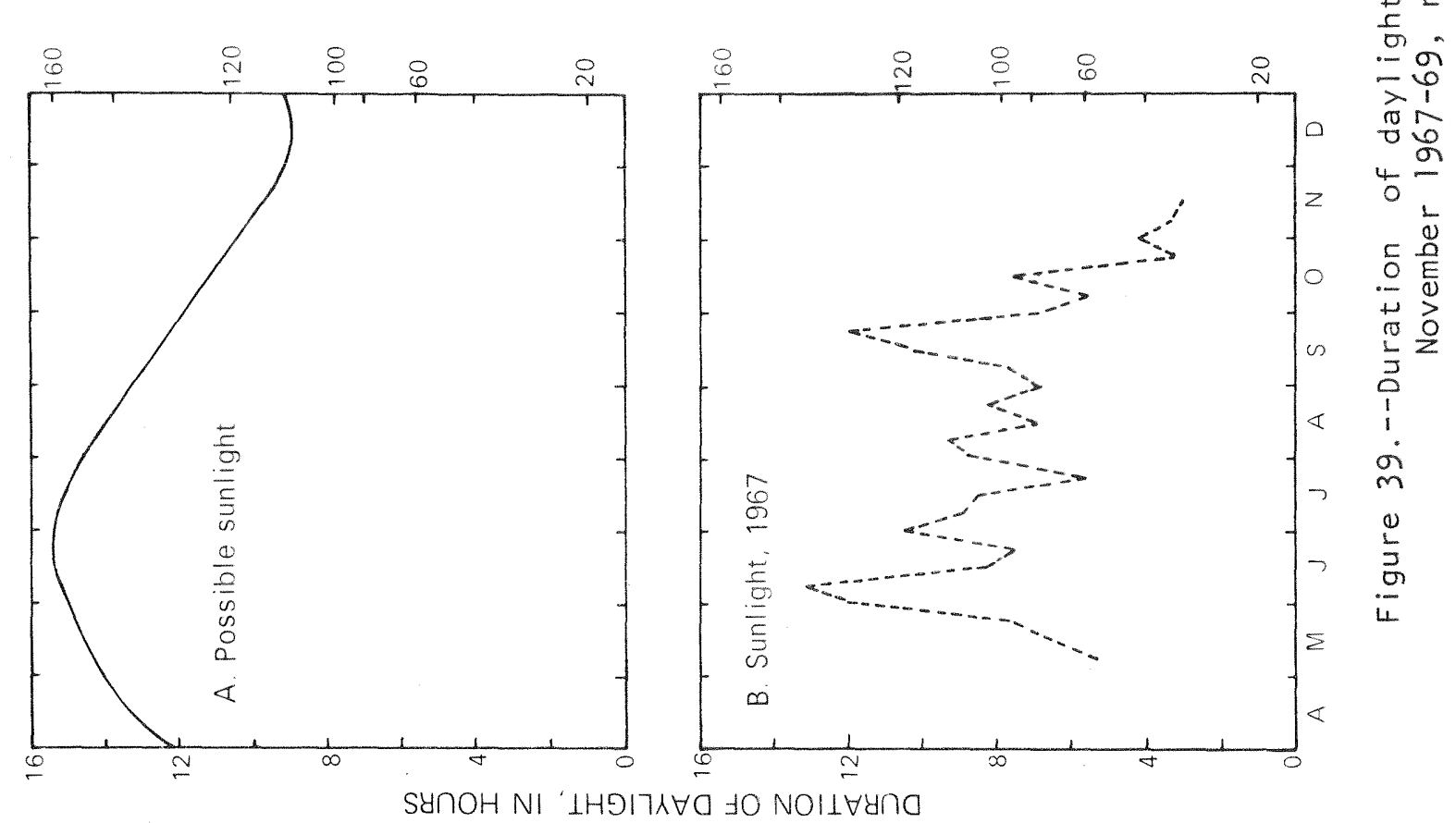


\begin{tabular}{|c|c|c|c|c|}
\hline \multicolumn{5}{|c|}{ (Values for } \\
\hline Vear & $\begin{array}{l}\text { Unit of } \\
\text { depth }\end{array}$ & \multicolumn{2}{|c|}{ Station } & $\begin{array}{l}\text { Lake } \\
\text { average }\end{array}$ \\
\hline 1967 & $\begin{array}{l}\text { feet } \\
\text { meters }\end{array}$ & $\begin{array}{l}6.95 \\
2.12\end{array}$ & $\begin{array}{l}5.59 \\
1.70\end{array}$ & $\begin{array}{l}6.32 \\
1.93\end{array}$ \\
\hline 1968 & $\begin{array}{l}\text { feet } \\
\text { meters }\end{array}$ & $\begin{array}{l}6.99 \\
2.13\end{array}$ & $\begin{array}{l}5.19 \\
1.58\end{array}$ & $\begin{array}{l}6.13 \\
1.87\end{array}$ \\
\hline 1969 & $\begin{array}{l}\text { feet } \\
\text { meters }\end{array}$ & $\begin{array}{l}5.22 \\
1.59\end{array}$ & $\begin{array}{l}4.93 \\
1.50\end{array}$ & $\begin{array}{l}5.08 \\
1.55\end{array}$ \\
\hline Mean & $\begin{array}{l}\text { feet } \\
\text { meters }\end{array}$ & $\begin{array}{l}6.41 \\
1.95\end{array}$ & $\begin{array}{l}5.24 \\
1.60\end{array}$ & $\begin{array}{l}5.86 \\
1.79\end{array}$ \\
\hline
\end{tabular}

Either of these two extremes, taken as a representative Secchi disc transparency, would have falsely characterized the conditions in Oneida Lake. Therefore, a series of readings should be made over an extended period of time.

Quantitative transmission of light in Oneida Lake was determined on october 1, 1969, between 1130 and 1330 hours. Measurements were made at five random locations. The lake was calm and the sky was clear and sunny. Incident illumination during the 2-hour period averaged 34,000 lux. Mean surface concentration of phytoplankton was 29,000 cells per milliliter, and the population was dominated by Aphanizomenon holsaticum.

Figure 40 illustrates the curve of light penetration. The 1-percent penetration depth averaged 13.1 feet $(4.0$ meters). This 1 -percent penetration depth was defined by Sauberer and Ruttner (1941, after Nall, 1965) and Talling (1962) as the lower limit of the euphotic zone. During the five measurements, the 1-percent penetration depth ranged from 11.7 feet $(3.6$ meters) to 17.2 feet ( 5.2 meters).

Concurrent Secchi disc transparency readings were made at each location. They averaged 5.6 feet $(1.7$ meters) and equalled the 10.5-percent penetration depth. 


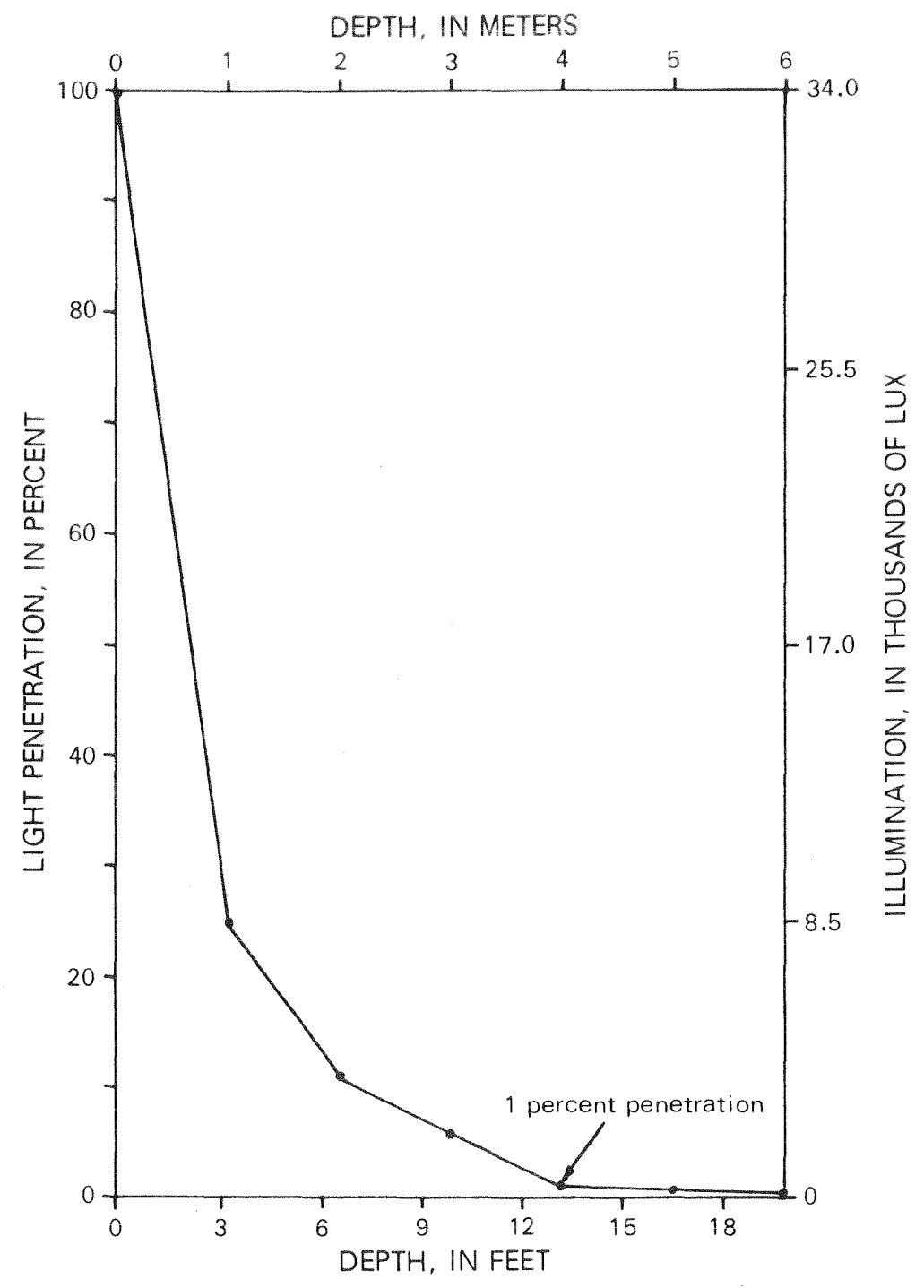

Figure 40.--Light penetration in Oneida Lake, October 1, 1969. 



\section{CHEMISTRY OF ONEIDA LAKE AND DRAINAGE BASIN}

\section{Nutrients}

Bodily processes of algae utilize dissolved substances from water in a lake. These substances (nutrients) are necessary for growth, repair of tissue, and reproduction. Any chemical element or compound required for the normal and healthy existence of an alga is a nutrient. Elements that are required in large quantities are known as macrometabolites (macronutrients or major nutrients), whereas those needed in minute quantities are called micrometabolites (micronutrients or minor nutrients). Micrometabolites are generally those essential elements that occur in trace quantities in the environment.

At least 21 elements in some chemical combination are known to be essential for the sustenance of algae. Most essential elements are required by all forms of algae. The essential elements and the estimated minimum requirement of each are listed in table 12. Minimum requirements of nutrients by the algae in the natural environment are difficult to determine. Uncertainty as to what concentrations of some elements are essential is shown by the wide range of minimum requirements in the table.

Knowledge of concentrations of essential elements in a lake is important, as concentrations serve as an index of nutrient enrichment and characterize the degree of lake eutrophication. Furthermore, if all other environmental factors are favorable, available nutrients decrease as the size of the algal population increases. At some point, one or more of the nutrients becomes depleted and the growth of the algae ceases. Thus, the maximum algal population that a lake can support depends on the availability of nutritive materials. An understanding of the limiting nutrient concentrations in a body of water is a step toward the control of eutrophic symptoms that are responsible for lake deterioration. The conditions of limiting factors were first described by Liebig in 1840 in what is called "the law of the minimum."

of the essential elements, nitrogen and phosphorus are considered to be key elements required by phytoplankton. In many lakes, concentrations of these two nutrients are considered vitally important in controlling biological production. When concentrations are high, algal blooms usually occur; when concentrations are low, no blooms occur.

Sawyer (1947) stated that when the concentrations of nitrogen and phosphorus exceeded 0.3 and $0.01 \mathrm{mg} / 1$ (milligram per liter), respectively, nuisance algal conditions can be expected. Even though nitrogen and phosphorus are frequently considered to be limiting factors in phytoplankton production, some studies have shown that neither was limiting (Kuentzel, 1969). This will be shown also to be true for Oneida Lake. Concentrations of these two elements in precipitation have been reported to be more than adequate for supporting algal blooms (Carroll, 1962 and Voight, 1960). (Also see section, "Chemical Contributions to Oneida Lake.") 
Table 12.--Elements essential to the production of algae

(from Greeson, 1969)

\begin{tabular}{|c|c|c|c|}
\hline Element & Symbol & $\begin{array}{c}\text { Minimum requirements } \\
\qquad(\mathrm{mg} / \mathrm{l})\end{array}$ & References \\
\hline (?) Aluminum & Al & Probably trace quantities & Meyer and others, 1964 \\
\hline Boron & B & 0.1 & Eyster, 1965; Provasoli, 1958 \\
\hline Calcium & $\mathrm{Ca}$ & 20 & $\begin{array}{l}\text { Allen and Arnon, 1955; Walker, } \\
\text { 1953 }\end{array}$ \\
\hline Carbon & $c$ & $\begin{array}{l}\text { Quantities always sufficient } \\
\text { in surrounding medium }\end{array}$ & Heyer and others, 1964 \\
\hline Chlorine & $\mathrm{Cl}$ & Trace quantities & $\begin{array}{l}\text { Levin, 1960; Meyer and others, } \\
1964\end{array}$ \\
\hline Cobalt & $\mathrm{Co}$ & .5 & $\begin{array}{l}\text { Buddhar } 1,1960 \text { after Miller and } \\
\text { Tash, 1967; Pirson, } 1937\end{array}$ \\
\hline Copper & $\mathrm{Cu}$ & .006 & Walker, 1953 \\
\hline Hydrogen & H & $\begin{array}{l}\text { Quantities always sufficient } \\
\text { in surrounding medium }\end{array}$ & Meyer and others, 1964 \\
\hline Iron & $\mathrm{Fe}$ & $.00065-6.0$ & $\begin{array}{l}\text { Gerloff and Skogg, 1957; Ryther } \\
\text { and Kramer, 1961; Schelske, } \\
1962\end{array}$ \\
\hline Magnes ium & $\mathrm{Mg}$ & Trace quantities & $\begin{array}{l}\text { Kratz and Myers, 1955; Krauss, } \\
1956\end{array}$ \\
\hline Manganese & $\mathrm{Mn}$ & .005 & $\begin{array}{l}\text { Gerloff and Skoff, 1957, Krauss, } \\
\text { 1956; Pirson, } 1937\end{array}$ \\
\hline Molybdenum & Mo & Trace quantities & $\begin{array}{l}\text { Bortels, 1940; Cobb and Meyers, } \\
1964 ; \text { Walker, } 1953\end{array}$ \\
\hline Nitrogen & N & Trace quantities -5.3 & $\begin{array}{l}\text { Birge and Juday, 1922; Chu, } \\
\text { 1943; Hutchinson, 1957; PaImer, } \\
1967 \text {; Sawyer, 1947 }\end{array}$ \\
\hline Oxygen & 0 & $\begin{array}{l}\text { Quantities always sufficient } \\
\text { in surrounding medium }\end{array}$ & Meyer and others, 1964 \\
\hline Phosphorus & P & $.002-.09$ & $\begin{array}{l}\text { Benoit and Curry, 1961; Chu, } \\
1943 ; \text { Gerloff and Skogg, 1954; } \\
\text { Rodhe, 1949; Sarles, 1961; } \\
\text { Sawyer, 1947 }\end{array}$ \\
\hline Potassium & K & Trace quantities & $\begin{array}{l}\text { Meyer and others, 1964; Krauss, } \\
1956\end{array}$ \\
\hline Silicon & si & $.5-.8$ & $\begin{array}{l}\text { Lund, 1959, 1954; Pearsall, } \\
1932\end{array}$ \\
\hline Sodium & $\mathrm{Na}$ & 5.0 & Phillips and others, 1965 \\
\hline Sulfur & s & $<5.0$ & $\begin{array}{l}\text { Fogg, 1966; Meyer and others, } \\
\text { 1964; Rodhe, } 1949\end{array}$ \\
\hline Vanadium & v & Trace quantities & $\begin{array}{l}\text { Provasoli, 1958; Shannon, } 1965 \\
\text { after Fruh, } 1967\end{array}$ \\
\hline Zinc & $\mathrm{Zn}$ & $.01-.1$ & $\begin{array}{l}\text { Provasoli, 1958; Provasoli and } \\
\text { Pinter, } 1953\end{array}$ \\
\hline
\end{tabular}


Methods of Routine Investigations

Water samples for chemical analysis were collected biweekly from Oneida Lake from May 1967 through April 1969. Samples from stations 8 through 22 (table 5 and fig. 9) were obtained from the lake surface and from 10-foot (3.05-meter) depth intervals with a Kemmerer water sampler. All samples were filtered through a 0.45 micrometer membrane filter in a water-sample filtration unit (Skougstad and Scarbro, 1968). Periodic unfiltered samples also were collected.

Each filtered sample was divided into three parts. One part, for the determination of nitrogen species (for example, nitrate, nitrite, ammonia, and organic nitrogen), was placed in a 500-milliliter polyethylene bottle and preserved with mercuric chloride $\left(\mathrm{HgCl}_{2}\right)$, as described by Jenkins (1968). A second aliquot was collected in a soft-glass (citrate of magnesia) bottle for determination of dissolved phosphate. The remainder of the filtered sample was stored in a $2-1$ iter polyethylene bottle.

All samples were returned to the U.S. Geological Survey laboratory in Albany for processing. Standard chemical analytical methods were used (American Public Health Association and others, 1965, or Rainwater and Thatcher, 1960). The following constituents were determined: silicon dioxide $\left(\mathrm{SiO}_{2}\right)$, calcium $(\mathrm{Ca})$, magnesium $(\mathrm{Mg})$, sodium $(\mathrm{Na})$, potassium $(\mathrm{K})$, bicarbonate $\left(\mathrm{HCO}_{3}\right)$, carbonate $\left(\mathrm{CO}_{3}\right)$, sulfate $\left(\mathrm{SO}_{4}\right)$, chloride (Cl), fluoride (F), nitrate $\left(\mathrm{NO}_{3}\right)$, nitrite $\left(\mathrm{NO}_{2}\right)$, ammonia $\left(\mathrm{NH}_{4}\right)$, organic nitrogen (org-N), total dissolved nitrogen (computed as $N$ ), and total dissolved phosphate $\left(\right.$ tot- $\mathrm{PO}_{4}$ ). The dissolved-solids content was computed as the sum of the determined constituents.

Dissolved oxygen, water temperature, and specific conductance were determined during each visit to a sampling station; $\mathrm{pH}$ and alkalinity were determined during some of the visits.

Periodic filtered samples were obtained at station 12 and occasionally at station $21 \mathrm{~b}$ for determination of trace metals by emission spectroscopy. Samples were filtered in the field and were stabilized with nitric acid $\left(\mathrm{HNO}_{3}\right)$. Laboratory work was done by the U.S. Geological Survey laboratory in Denver, Colorado, and results were reported in micrograms per liter $(\mu \mathrm{g} / \mathrm{l})$, which is milligrams per liter $\times 10^{-3}$. Metals included in the determinations were: aluminum ( $A 1)$, barlum $(B a)$, beryllium (Be), bismuth $(B i)$, boron (B), cadmium (Cd), chromium $(\mathrm{Cr})$, cobalt (Co), copper (Cu), gallium (Ga), germanium $(\mathrm{Ge})$, iron $(\mathrm{Fe})$, lead $(\mathrm{Pb})$, lithium $(\mathrm{Li})$, manganese $(\mathrm{Mn})$, molybdenum (Mo), nickel (Ni), rubidium $(\mathrm{Rb})$, silver $(\mathrm{Ag})$, strontium $(S r)$, tin $(S n)$, titanium $(T i)$, vanadium $(V)$, zinc $(\mathrm{Zn})$, and zirconium $(\mathrm{Zr})$.

To determine individual nutrient budgets (that is, amounts of nutrient inflows and outflow) for Oneida Lake, periodic samples were collected from tributary stations, $C$ through 7 (table 6 ). Analytical methods used both in the field and in the laboratory were the same as described above.

An instantaneous discharge was determined when a sample was collected from a tributary station. The derived data provided the relationship between stream discharge and water chemistry. Most discharges were determined by current-meter measurement. Discharge based on stream stage was 
sometimes used for gaged sites and for long-term partial record stations where a stage-discharge relationship had been established.

Long-term data and interpretive methods are not available for the chemistry of most streams; so these data must be determined indirectly as mean annual chemical loads, which are used in the determination of nutrient budgets. The particular method used in this study was described by Pearson and Meyers (in press). The method establishes the relationship between stream discharge and individual concentrations of dissolved nutrients. Long-term stream discharge data and the relationship are used then to determine the mean annual nutrient contents.

Several simultaneous discharge and chemical measurements are required to construct such curves. Measurements do not have to be dispersed over many years but must represent a wide range of instantaneous discharges in order to define as much of the curve as possible (Pearson and Meyers, in press). During the study, measurements were made biweekly to monthly for about 2 years and included measurements at times of extreme high and low flows.

\section{Variations of the Chemical Constituents in Oneida Lake}

Oneida Lake lies within a fertile drainage basin. On an average day about 1,250 tons of dissolved solids are carried into the lake by streams (Pearson and Meyers, in press). About 11 percent, or about 137 tons of these materials, is retained or entrapped within the lake. Because the streams of the basin contain primarily calcium sulfate and calcium bicarbonate water, a large part of the dissolved solids flowing into the lake is of direct nutritional value to algae and to other plants.

Nutrients entering the lake become incorporated in various chemicalcycling processes. Part of the nutrients are utilized in the metabolism of organisms (for example, phytoplankton, zooplankton, vascular plants, and fish); and on death and decay of the organisms nutrients are liberated for reuse. Part of the nutrients remain in solution; part become temporarily or permanently incorporated in the bottom sediments; and part flow out of the lake.

Part of the nutrients accumulate in the lake and, after a period of years, become available in concentrations sufficient to support algal blooms. Concentrations of nutrients in Oneida Lake reached essential levels many years ago and, subsequently, have increased in concentration. The slow buildup of nutrients in oneida Lake will continue for many years. The buildup is, in essence, the inevitable natural process of eutrophication.

Spatial and temporal variations of chemical constituents in Oneida Lake during the study resulted primarily from fluctuating inputs of chemical loads from the drainage basin. 


\section{Spatial Differences}

On any sampling day during ice-free conditions, concentrations of dissolved nutrients in Oneida Lake were virtually uniform both vertically and areally; only subtle differences were detected. The ever-present winds immediately mixed water from tributaries entering the lake. Significant differences are discussed in the section, "Ice Cover."

Mean, maximum, and minimum values of the chemical constituents at each sampling station on Oneida Lake during the study period are given in table 13. Part of the data from which this table and succeeding tables were developed has been published by the U.S. Geological Survey (1969a, 1970a, and 1971). A complete tabulation of routinely collected data is shown in the Appendix (tables 30 and 31 ).

The high range of values indicated for the constituents at several stations reflects the unique situation when water masses were isolated under ice cover. For example, the lowest dissolved-solids content during the study was $57 \mathrm{mg} / 1$. The sample was collected from station 9 on December 18, 1967. The highest dissolved-solids content during the study was 282 $\mathrm{mg} / 1$ at station $21 \mathrm{~b}$ on February 27, 1968. Both extreme values occurred during ice conditions and exemplify separation of water masses.

As indicated in the discussion of Secchi-disc transparency, circumstances that prevail during sample collection can greatly influence the results. Analytical results from a single sample or from a series of samples collected over a brief period of time can imply erroneous conditions because chemical conditions can change by day, season, and year. Combined results of many samples collected over a long period will approximate more closely the true chemical conditions in the lake. Mean values shown in table 13 fulfill this requirement.

Areal varlations of the dissolved-solids content of Oneida Lake were slight during the study. Figure $41 \mathrm{~A}$ indicates that slightly higher dissolved-solids contents were recorded at the west stations (numbers 17 through 22) than at the rest of the stations. The mean dissolved-solids content at these six stations was $168 \mathrm{mg} / 1$; at the east stations (numbers 8 through 13) it was $163 \mathrm{mg} / 1$.

South stations (numbers $8,11,14,17$, and 20) had a mean dissolvedsolids content of $170 \mathrm{mg} / \mathrm{l}(\mathrm{fig} .4 \mathrm{iB})$, which was slightly higher than the $164 \mathrm{mg} / 1$ at the north stations (numbers 10, 13, 16, 19, and 22). The midlake stations (numbers 9, 12, 15, 18, and 21) had a mean dissolved-solids content of $159 \mathrm{mg} / 1$. This somewhat lower mean value for the mid-lake stations reflects the low winter dissolved-solids content at station 9, which resulted from the inflow of low-mineralized water from Fish and Wood Creeks. Enriched water from Oneida, Canaseraga, Cowaselon, and Chittenango Creeks accounts for the slightly higher dissolved-solids content along the south shore and the west end of the lake.

In the vertical profile (fig. 4ic) the dissolved-solids content was virtually uniform. A small increase was observed at the 50-foot depth (15.2 meters). Mean dissolved-solids contents at the surface and at 50foot (15.2 meters) were 170 and $177 \mathrm{mg} / 1$, respectively. 
Table 13.--Mean, maximum, and minimum values of physical properties, chemical constituents, and phytoplankton at each sampling station on Oneida Lake, May 1967 through October 1969

(Values are for surface samples and except for pH represent milligrans per liter unless otherwise indicated

\begin{tabular}{|c|c|c|c|c|c|c|c|c|c|c|c|c|c|c|c|c|c|c|c|c|c|c|c|c|}
\hline Station & & $\mathrm{PH}$ & $\begin{array}{l}\text { Dis- } \\
\text { solved } \\
\text { oxygen }\end{array}$ & $\begin{array}{l}\text { Dis- } \\
\text { solved } \\
\text { oxygen } \\
\text { (percent } \\
\text { satuo } \\
\text { ration) }\end{array}$ & $\begin{array}{c}\text { Specific } \\
\text { conduct- } \\
\text { ance } \\
\text { (wanhos/cm } \\
\text { at } \\
\left.25^{\circ} \mathrm{C}\right)\end{array}$ & $\begin{array}{l}\text { Temper- } \\
\text { ature } \\
\left({ }^{\circ} \mathrm{C}\right)\end{array}$ & $\begin{array}{l}\text { Silica } \\
\left(\mathrm{SiO}_{2}\right)\end{array}$ & $\begin{array}{l}\text { Cal- } \\
\text { ciump } \\
\text { (Ca) }\end{array}$ & $\begin{array}{l}\text { Magnew } \\
\text { sicm } \\
\text { (Mg) }\end{array}$ & $\begin{array}{l}\text { Stron } \\
\text { tium } \\
(\mathrm{sr})\end{array}$ & $\begin{array}{c}\text { Sodi iurs } \\
\text { (Na) }\end{array}$ & $\begin{array}{l}\text { Potas- } \\
\text { silum } \\
(k)\end{array}$ & $\begin{array}{l}\text { Bicar- } \\
\text { bonate } \\
\text { (Hico })\end{array}$ & $\begin{array}{l}\text { sur- } \\
\text { fate } \\
\text { (50, }\end{array}$ & $\begin{array}{l}\text { chlow } \\
\text { ride } \\
\text { (c) }\end{array}$ & $\begin{array}{l}\text { Fluo- } \\
\text { ride } \\
\text { (F) }\end{array}$ & $\begin{array}{l}\text { N:- } \\
\text { trate } \\
\text { (No })\end{array}$ & $\begin{array}{l}\text { Ni- } \\
\text { trite } \\
\text { (No }\end{array}$ & $\begin{array}{l}\text { Angre- } \\
\text { nitum } \\
\left(\mathrm{NHH}_{4}\right)\end{array}$ & $\begin{array}{l}\text { arganic } \\
\text { nitro- } \\
\text { gen } \\
\text { (N) }\end{array}$ & $\begin{array}{l}\text { Total } \\
\text { nitrom } \\
\text { gen } \\
\text { (N) }\end{array}$ & $\begin{array}{l}\text { Total } \\
\text { phos- } \\
\text { phate } \\
\text { (P0.4) }\end{array}$ & $\begin{array}{l}\text { Dis- } \\
\text { solved } \\
\text { solids } \\
\text { (residue } \\
\text { at } \\
180^{\circ} \mathrm{C} \text { ) } \\
\end{array}$ & $\begin{array}{l}\text { Phyto- } \\
\text { planikton } \\
\text { (cells/mil }\end{array}$ \\
\hline 8 & $\begin{array}{l}\text { Maximum } \\
\text { MEAN } \\
\text { Min Imumt }\end{array}$ & $\begin{array}{l}8.9 \\
8.3 \\
7.7\end{array}$ & $\begin{array}{r}12.10 \\
9.43 \\
7.20\end{array}$ & $\begin{array}{r}123.4 \\
105.2 \\
79.0\end{array}$ & $\begin{array}{l}320 \\
285 \\
220\end{array}$ & $\begin{array}{r}26.0 \\
20.4 \\
.0\end{array}$ & $\begin{array}{r}2.4 \\
1.4 \\
.2\end{array}$ & $\begin{array}{l}43 \\
4 ! \\
39\end{array}$ & $\begin{array}{l}9.9 \\
9.2 \\
8.5\end{array}$ & $\begin{array}{r}0.56 \\
.56 \\
.56\end{array}$ & $\begin{array}{l}5.5 \\
5.1 \\
4.4\end{array}$ & $\begin{array}{r}1.1 \\
.9 \\
.8\end{array}$ & $\begin{array}{c}108 \\
103 \\
95\end{array}$ & $\begin{array}{l}57 \\
55 \\
50\end{array}$ & $\begin{array}{l}10 \\
9.5 \\
9.0\end{array}$ & $\begin{array}{r}0.2 \\
.1 \\
.0\end{array}$ & $\begin{array}{r}0.2 \\
.1 \\
.0\end{array}$ & $\begin{array}{l}0.03 \\
.01 \\
.00\end{array}$ & $\begin{array}{l}0.17 \\
.07 \\
.00\end{array}$ & $\begin{array}{r}0.19 \\
.15 \\
.09\end{array}$ & $\begin{array}{r}0.25 \\
.18 \\
.09\end{array}$ & $\begin{array}{l}0.26 \\
.08 \\
.03\end{array}$ & $\begin{array}{l}179 \\
173 \\
166\end{array}$ & $\begin{array}{c}94,400 \\
12,500 \\
<1\end{array}$ \\
\hline 9 & $\begin{array}{l}\text { Maximum } \\
\text { MEAN } \\
\text { MAnimimang }\end{array}$ & $\begin{array}{l}8.7 \\
7.8 \\
7.3\end{array}$ & $\begin{array}{r}12.00 \\
9.79 \\
7.20\end{array}$ & $\begin{array}{r}133.8 \\
107.9 \\
81.4\end{array}$ & $\begin{array}{r}315 \\
238 \\
98\end{array}$ & $\begin{array}{r}25.5 \\
16.9 \\
.0\end{array}$ & $\begin{array}{r}4.8 \\
2.9 \\
.9\end{array}$ & $\begin{array}{l}42 \\
30 \\
12\end{array}$ & $\begin{array}{l}9.5 \\
7.6 \\
3.5\end{array}$ & $\begin{array}{l}.56 \\
.24 \\
.01\end{array}$ & $\begin{array}{l}5.0 \\
4.1 \\
2.1\end{array}$ & $\begin{array}{l}1.2 \\
.8 \\
.3\end{array}$ & $\begin{array}{r}106 \\
83 \\
38\end{array}$ & $\begin{array}{l}55 \\
34 \\
11\end{array}$ & $\begin{array}{l}9.5 \\
7.5 \\
3.5\end{array}$ & $\begin{array}{l}.3 \\
.1 \\
.0\end{array}$ & $\begin{array}{r}2.0 \\
.7 \\
.0\end{array}$ & $\begin{array}{l}.22 \\
.01 \\
.00\end{array}$ & $\begin{array}{r}1.10 \\
.14 \\
.00\end{array}$ & $\begin{array}{r}.39 \\
.11 \\
.00\end{array}$ & $\begin{array}{l}.88 \\
.36 \\
.09\end{array}$ & $\begin{array}{l}1.01 \\
.17 \\
.02\end{array}$ & $\begin{array}{r}176 \\
127 \\
57\end{array}$ & $\begin{array}{l}65,400 \\
8,900 \\
<1\end{array}$ \\
\hline 10 & $\begin{array}{l}\text { Maximum } \\
\text { HeAN } \\
\text { Minimum }\end{array}$ & $\begin{array}{l}8.6 \\
8.2 \\
7.8\end{array}$ & $\begin{array}{r}11.82 \\
9.50 \\
7.68\end{array}$ & $\begin{array}{l}129.4 \\
307.1 \\
90.0\end{array}$ & $\begin{array}{l}350 \\
275 \\
190\end{array}$ & $\begin{array}{r}28.5 \\
21.1 \\
.0\end{array}$ & $\begin{array}{r}2.4 \\
1.5 \\
.3\end{array}$ & $\begin{array}{l}50 \\
40 \\
29\end{array}$ & $\begin{array}{l}9.6 \\
8.7 \\
6.4\end{array}$ & $\begin{array}{l}-- \\
--\end{array}$ & $\begin{array}{l}5.3 \\
4.8 \\
3.3\end{array}$ & $\begin{array}{r}1.0 \\
.8 \\
.7\end{array}$ & $\begin{array}{l}104 \\
99 \\
78\end{array}$ & $\begin{array}{l}57 \\
50 \\
30\end{array}$ & $\begin{array}{l}9.5 \\
8.3 \\
5.2\end{array}$ & $\begin{array}{l}.2 \\
.1 \\
.0\end{array}$ & $\begin{array}{r}5.7 \\
.7 \\
.0\end{array}$ & $\begin{array}{l}.02 \\
.01 \\
.00\end{array}$ & $\begin{array}{l}.24 \\
.09\end{array}$ & $\begin{array}{l}.23 \\
.16 \\
.12\end{array}$ & $\begin{array}{r}1.33 \\
.62 \\
.26\end{array}$ & $\begin{array}{l}.40 \\
.10 \\
.02\end{array}$ & $\begin{array}{l}175 \\
162 \\
120\end{array}$ & $\begin{array}{l}46,000 \\
8,300 \\
<1\end{array}$ \\
\hline 11 & $\begin{array}{l}\text { Maximum } \\
\text { MEAN } \\
\text { Mintrum }\end{array}$ & $\begin{array}{l}9.0 \\
8.4 \\
8.1\end{array}$ & $\begin{array}{l}12.03 \\
9.27 \\
7.45\end{array}$ & $\begin{array}{l}115.4 \\
104.8 \\
87.0\end{array}$ & $\begin{array}{l}315 \\
294 \\
265\end{array}$ & $\begin{array}{r}25.2 \\
21.0 \\
.0\end{array}$ & $\begin{array}{r}3.0 \\
1.3 \\
.2\end{array}$ & $\begin{array}{l}41 \\
4,1 \\
39\end{array}$ & $\begin{array}{l}3.6 \\
9.0 \\
8.5\end{array}$ & $\begin{array}{l}.57 \\
.57 \\
.57\end{array}$ & $\begin{array}{l}5.4 \\
5.1 \\
4.4\end{array}$ & $\begin{array}{l}1.1 \\
.9 \\
.8\end{array}$ & $\begin{array}{l}111 \\
103 \\
96\end{array}$ & $\begin{array}{l}57 \\
54 \\
50\end{array}$ & $\begin{array}{l}9.9 \\
9.4 \\
8.8\end{array}$ & $\begin{array}{l}.2 \\
.1 \\
.0\end{array}$ & $\begin{array}{l}.2 \\
.1 \\
0\end{array}$ & $\begin{array}{l}.03 \\
.01 \\
.00\end{array}$ & $\begin{array}{l}.30 \\
.31 \\
.00\end{array}$ & $\begin{array}{l}.28 \\
.36 \\
.02\end{array}$ & $\begin{array}{l}.30 \\
.20 \\
.03\end{array}$ & $\begin{array}{l}.49 \\
.10 \\
.01\end{array}$ & $\begin{array}{l}175 \\
175 \\
165\end{array}$ & $\begin{array}{l}33,700 \\
10,100 \\
<1\end{array}$ \\
\hline 12 & $\begin{array}{l}\text { Maximum } \\
\text { MEAM } \\
\text { Minioum }\end{array}$ & $\begin{array}{l}8.8 \\
8.1 \\
7.4\end{array}$ & $\begin{array}{l}17.85 \\
10.06 \\
5.27\end{array}$ & $\begin{array}{l}165.4 \\
107.7 \\
56.7\end{array}$ & $\begin{array}{l}310 \\
277 \\
235\end{array}$ & $\begin{array}{r}26.3 \\
18.9 \\
.0\end{array}$ & $\begin{array}{r}4.3 \\
2.1 \\
.0\end{array}$ & $\begin{array}{l}43 \\
39 \\
17\end{array}$ & $\begin{array}{l}10.0 \\
8.6 \\
4.7\end{array}$ & $\begin{array}{l}.61 \\
.52 \\
.38\end{array}$ & $\begin{array}{l}6.8 \\
5.0 \\
3.1\end{array}$ & $\begin{array}{l}1.3 \\
1.0 \\
.6\end{array}$ & $\begin{array}{l}108 \\
100 \\
55\end{array}$ & $\begin{array}{l}56 \\
49 \\
13\end{array}$ & $\begin{array}{l}9.8 \\
9.0 \\
5.0\end{array}$ & $\begin{array}{l}.2 \\
.1 \\
.0\end{array}$ & $\begin{array}{r}2.4 \\
.4 \\
.0\end{array}$ & $\begin{array}{l}.12 \\
.01 \\
.00\end{array}$ & $\begin{array}{l}.52 \\
.10 \\
.00\end{array}$ & $\begin{array}{l}.63 \\
.14 \\
.00\end{array}$ & $\begin{array}{l}.71 \\
.32 \\
.06\end{array}$ & $\begin{array}{l}.73 \\
.00\end{array}$ & $\begin{array}{r}274 \\
169 \\
77\end{array}$ & $\begin{array}{c}291,900 \\
17,900 \\
<1\end{array}$ \\
\hline 13 & $\begin{array}{l}\text { Maximum } \\
\text { MEABA } \\
\text { Mintoum }\end{array}$ & $\begin{array}{l}9.0 \\
8.4 \\
7.4\end{array}$ & $\begin{array}{r}14.21 \\
9.52 \\
7.18\end{array}$ & $\begin{array}{r}132.3 \\
105.1 \\
83.7\end{array}$ & $\begin{array}{l}310 \\
268 \\
310\end{array}$ & $\begin{array}{r}25.8 \\
20.3 \\
.0\end{array}$ & $\begin{array}{r}3.5 \\
1.9 \\
.2\end{array}$ & $\begin{array}{l}43 \\
39 \\
30\end{array}$ & $\begin{array}{l}9.5 \\
8.8 \\
7.0\end{array}$ & $\begin{array}{l}-- \\
--\end{array}$ & $\begin{array}{l}5.5 \\
5.0 \\
3.9\end{array}$ & $\begin{array}{r}1.1 \\
.9 \\
.8\end{array}$ & $\begin{array}{l}107 \\
100 \\
83\end{array}$ & $\begin{array}{l}55 \\
50 \\
31\end{array}$ & $\begin{array}{l}10 \\
8.9 \\
7.1\end{array}$ & $\begin{array}{l}.2 \\
.1 \\
.0\end{array}$ & $\begin{array}{r}1.1 \\
.2 \\
.0\end{array}$ & $\begin{array}{l}.03 \\
.01 \\
.00\end{array}$ & $\begin{array}{r}.59 \\
.14 \\
.00\end{array}$ & $\begin{array}{l}.45 \\
.27 \\
.07\end{array}$ & $\begin{array}{l}.51 \\
.38 \\
.22\end{array}$ & $\begin{array}{l}.42 \\
.12 \\
.00\end{array}$ & $\begin{array}{l}178 \\
167 \\
125\end{array}$ & $\begin{array}{l}22,100 \\
5,500 \\
<1\end{array}$ \\
\hline 14 & $\begin{array}{l}\text { Maximum } \\
\text { MeAs } \\
\text { Minimum }\end{array}$ & $\begin{array}{l}8.6 \\
7.9 \\
7.3\end{array}$ & $\begin{array}{l}13.60 \\
9.66 \\
5.01\end{array}$ & $\begin{array}{r}127.8 \\
100.4 \\
66.5\end{array}$ & $\begin{array}{l}310 \\
271 \\
75\end{array}$ & $\begin{array}{r}25.0 \\
17.9 \\
.0\end{array}$ & $\begin{array}{r}6.1 \\
2.2 \\
.3\end{array}$ & $\begin{array}{l}44 \\
38 \\
23\end{array}$ & $\begin{array}{l}9.5 \\
8.7 \\
5.9\end{array}$ & $\begin{array}{l}.60 \\
.47 \\
.30\end{array}$ & $\begin{array}{l}5.4 \\
4.8 \\
3.4\end{array}$ & $\begin{array}{l}1.2 \\
.9\end{array}$ & $\begin{array}{l}110 \\
99 \\
69\end{array}$ & $\begin{array}{l}59 \\
49 \\
23\end{array}$ & $\begin{array}{l}10 \\
9.0 \\
6.0\end{array}$ & $\begin{array}{l}.4 \\
.1 \\
.9\end{array}$ & $\begin{array}{r}3.5 \\
.6 \\
.0\end{array}$ & $\begin{array}{l}.04 \\
.01\end{array}$ & $\begin{array}{l}.54 \\
.10 \\
.00\end{array}$ & $\begin{array}{l}.67 \\
.27 \\
.02\end{array}$ & $\begin{array}{l}.13 \\
.47 \\
.12\end{array}$ & $\begin{array}{l}.24 \\
.08 \\
.00\end{array}$ & $\begin{array}{l}184 \\
162 \\
104\end{array}$ & 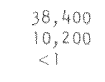 \\
\hline 15 & $\begin{array}{l}\text { Maximum } \\
\text { MEAN } \\
\text { Minirnum }\end{array}$ & $\begin{array}{l}8.8 \\
8.0 \\
7.2\end{array}$ & $\begin{array}{l}77.85 \\
10.20 \\
6.09\end{array}$ & $\begin{array}{l}159.9 \\
108.4 \\
66.0\end{array}$ & $\begin{array}{l}310 \\
275 \\
220\end{array}$ & $\begin{array}{r}27.8 \\
17.8 \\
.0\end{array}$ & $\begin{array}{r}4.5 \\
2.1 \\
.0\end{array}$ & $\begin{array}{l}43 \\
37 \\
19\end{array}$ & $\begin{array}{l}9.7 \\
8.4 \\
5.2\end{array}$ & $\begin{array}{l}.54 \\
.48 \\
.27\end{array}$ & $\begin{array}{l}5.7 \\
4.8 \\
3.5\end{array}$ & $\begin{array}{l}1.3 \\
1.0 \\
.7\end{array}$ & $\begin{array}{l}108 \\
96 \\
63\end{array}$ & $\begin{array}{l}55 \\
45 \\
16\end{array}$ & $\begin{array}{l}9.8 \\
8.9 \\
5.8\end{array}$ & $\begin{array}{l}.2 \\
.1 \\
.0\end{array}$ & $\begin{array}{r}2.0 \\
.5 \\
.0\end{array}$ & $\begin{array}{l}.04 \\
.01 \\
.00\end{array}$ & $\begin{array}{r}1.50 \\
.13 \\
.00\end{array}$ & $\begin{array}{r}.39 \\
.14 \\
.00\end{array}$ & $\begin{array}{l}.67 \\
.31 \\
.00\end{array}$ & $\begin{array}{l}.44 \\
.13 \\
.00\end{array}$ & $\begin{array}{l}177 \\
156 \\
87\end{array}$ & $\begin{array}{l}75,300 \\
10,500 \\
<1\end{array}$ \\
\hline 16 & $\begin{array}{l}\text { Maximum } \\
\text { MEAN } \\
\text { Minimum }\end{array}$ & $\begin{array}{l}8.7 \\
8.2 \\
7.3\end{array}$ & $\begin{array}{r}10.83 \\
9.12 \\
7.16\end{array}$ & $\begin{array}{r}131.3 \\
105.8 \\
83.4\end{array}$ & $\begin{array}{l}310 \\
293 \\
280\end{array}$ & $\begin{array}{r}26.5 \\
21.9 \\
.0\end{array}$ & $\begin{array}{r}2.9 \\
1.7 \\
.2\end{array}$ & $\begin{array}{l}42 \\
41 \\
39\end{array}$ & $\begin{array}{l}9.8 \\
0.3 \\
9.1\end{array}$ & $\begin{array}{l}-- \\
--\end{array}$ & $\begin{array}{l}5.3 \\
5.2 \\
5.0\end{array}$ & $\begin{array}{l}1.0 \\
.9 \\
.7\end{array}$ & $\begin{array}{l}107 \\
102 \\
92\end{array}$ & $\begin{array}{l}56 \\
54 \\
53\end{array}$ & $\begin{array}{l}9.4 \\
9.1 \\
8.8\end{array}$ & $\begin{array}{l}.2 \\
.1\end{array}$ & .2 & $\begin{array}{l}.02 \\
.01 \\
.00\end{array}$ & $\begin{array}{l}.70 \\
.21 \\
.00\end{array}$ & $\begin{array}{l}.39 \\
.22 \\
.05\end{array}$ & $\begin{array}{l}.61 \\
.34 \\
.07\end{array}$ & $\begin{array}{l}.41 \\
.13 \\
.00\end{array}$ & $\begin{array}{l}174 \\
172 \\
169\end{array}$ & $\begin{array}{l}\begin{array}{l}66,700 \\
12,600 \\
<1\end{array}\end{array}$ \\
\hline 17 & $\begin{array}{l}\text { Maximum } \\
\text { MEANA } \\
\text { Min imumerm }\end{array}$ & $\begin{array}{l}8.6 \\
8.3 \\
7.9\end{array}$ & $\begin{array}{r}12.18 \\
9.22 \\
7.00\end{array}$ & $\begin{array}{r}153.0 \\
105.8 \\
80.4\end{array}$ & $\begin{array}{l}320 \\
294 \\
260\end{array}$ & $\begin{array}{r}27.0 \\
21.6 \\
.0\end{array}$ & $\begin{array}{r}3.8 \\
1.7 \\
.5\end{array}$ & $\begin{array}{l}43 \\
41 \\
39\end{array}$ & $\begin{array}{l}9.7 \\
9.2 \\
8.1\end{array}$ & $\begin{array}{l}.53 \\
.53 \\
.53\end{array}$ & $\begin{array}{l}5.4 \\
5.0 \\
4.2\end{array}$ & $\begin{array}{l}1.1 \\
1.8 \\
.8\end{array}$ & $\begin{array}{l}110 \\
103 \\
98\end{array}$ & $\begin{array}{l}60 \\
54 \\
48\end{array}$ & $\begin{array}{l}10 \\
9.3 \\
9.0\end{array}$ & .2 & $\begin{array}{l}.5 \\
.2 \\
.0\end{array}$ & $\begin{array}{l}.04 \\
.01 \\
.00\end{array}$ & $\begin{array}{l}.70 \\
.19 \\
.00\end{array}$ & $\begin{array}{r}.18 \\
.15 \\
.14\end{array}$ & $\begin{array}{l}.32 \\
.25 \\
.15\end{array}$ & $\begin{array}{l}.30 \\
.31 \\
.02\end{array}$ & $\begin{array}{l}186 \\
173 \\
159\end{array}$ & 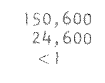 \\
\hline 18 & $\begin{array}{l}\text { Maximum } \\
\text { MEAN } \\
\text { Minimum }\end{array}$ & $\begin{array}{l}8.7 \\
8.1 \\
7.5\end{array}$ & $\begin{array}{l}18.03 \\
10.26 \\
8.81\end{array}$ & $\begin{array}{l}148.6 \\
111.2 \\
88.1\end{array}$ & $\begin{array}{l}315 \\
280 \\
240\end{array}$ & $\begin{array}{r}26.9 \\
19.1 \\
.0\end{array}$ & $\begin{array}{r}4.7 \\
1.9 \\
.0\end{array}$ & $\begin{array}{l}43 \\
40 \\
33\end{array}$ & $\begin{array}{l}9.8 \\
8.8 \\
7.4\end{array}$ & $\begin{array}{l}.58 \\
.55 \\
.54\end{array}$ & $\begin{array}{l}5.6 \\
5.0 \\
4.3\end{array}$ & $\begin{array}{l}1.2 \\
1.0 \\
.8\end{array}$ & $\begin{array}{l}111 \\
103 \\
91\end{array}$ & $\begin{array}{l}56 \\
50 \\
33\end{array}$ & $\begin{array}{l}11 . \\
9.3 \\
8.5\end{array}$ & $\begin{array}{l}3 \\
.1 \\
.0\end{array}$ & $\begin{array}{r}2.3 \\
.4 \\
.0\end{array}$ & $\begin{array}{l}.10 \\
.01 \\
.00\end{array}$ & $\begin{array}{r}1.40 \\
.14 \\
.00\end{array}$ & $\begin{array}{r}.36 \\
.14 \\
.00\end{array}$ & $\begin{array}{l}.67 \\
.28 \\
.01\end{array}$ & $\begin{array}{l}.52 \\
.14 \\
.02\end{array}$ & $\begin{array}{l}181 \\
168 \\
163\end{array}$ & $\begin{array}{l}55,200 \\
11,200\end{array}$ \\
\hline 19 & $\begin{array}{l}\text { Maximum } \\
\text { MEAN } \\
\text { Minimimum }\end{array}$ & $\begin{array}{l}9.0 \\
8.4 \\
7.9\end{array}$ & $\begin{array}{r}11.00 \\
9.04 \\
7.00\end{array}$ & $\begin{array}{l}138.7 \\
103.0 \\
83.7\end{array}$ & $\begin{array}{l}310 \\
291 \\
250\end{array}$ & $\begin{array}{r}27.2 \\
21.1 \\
.0\end{array}$ & $\begin{array}{r}3.8 \\
2.0 \\
.2\end{array}$ & $\begin{array}{l}43 \\
40 \\
35\end{array}$ & $\begin{array}{l}9.7 \\
8.9 \\
7.2\end{array}$ & $\begin{array}{l}.53 \\
.53 \\
.53\end{array}$ & $\begin{array}{l}5.2 \\
5.0 \\
4.5\end{array}$ & $\begin{array}{l}1.0 \\
.9 \\
.7\end{array}$ & $\begin{array}{l}110 \\
102 \\
92\end{array}$ & $\begin{array}{l}56 \\
50 \\
37\end{array}$ & $\begin{array}{l}9.9 \\
9.3 \\
8.6\end{array}$ & $\begin{array}{l}.2 \\
.1 \\
.0\end{array}$ & $\begin{array}{l}.4 \\
.2 \\
.1\end{array}$ & $\begin{array}{l}.03 \\
.01 \\
.00\end{array}$ & $\begin{array}{l}.49 \\
.17 \\
.00\end{array}$ & $\begin{array}{l}.32 \\
.25 \\
.21\end{array}$ & $\begin{array}{l}.63 \\
.42 \\
.23\end{array}$ & $\begin{array}{l}.24 \\
.09 \\
.00\end{array}$ & $\begin{array}{l}176 \\
167 \\
144\end{array}$ & $\begin{array}{l}43,300 \\
14,200 \\
\leqslant !\end{array}$ \\
\hline 20 & $\begin{array}{l}\text { Maximum } \\
\text { MEAM } \\
\text { Minimimurs }\end{array}$ & $\begin{array}{l}9.0 \\
8.6 \\
8.1\end{array}$ & $\begin{array}{r}14.16 \\
9.50 \\
6.30\end{array}$ & $\begin{array}{l}177.2 \\
109.0 \\
74.0\end{array}$ & $\begin{array}{l}305 \\
282 \\
240\end{array}$ & $\begin{array}{r}26.8 \\
21.5 \\
.0\end{array}$ & $\begin{array}{r}3.5 \\
1.8 \\
.2\end{array}$ & $\begin{array}{l}42 \\
40 \\
37\end{array}$ & $\begin{array}{l}9.6 \\
9.0 \\
7.9\end{array}$ & $\begin{array}{l}.54 \\
.54 \\
.54\end{array}$ & $\begin{array}{l}7.1 \\
5.3 \\
4.3\end{array}$ & $\begin{array}{l}1.1 \\
.9 \\
.8\end{array}$ & $\begin{array}{r}107 \\
99 \\
87\end{array}$ & $\begin{array}{l}54 \\
53 \\
49\end{array}$ & $\begin{array}{l}9.9 \\
9.5 \\
9.1\end{array}$ & $\begin{array}{l}.2 \\
.1 \\
.0\end{array}$ & $\begin{array}{l}.2 \\
.1 \\
.0\end{array}$ & $\begin{array}{l}.02 \\
.01 \\
.00\end{array}$ & $\begin{array}{l}.54 \\
.16 \\
.00\end{array}$ & $\begin{array}{r}.35 \\
.23 \\
.11\end{array}$ & $\begin{array}{l}.38 \\
.26 \\
.13\end{array}$ & $\begin{array}{l}.41 \\
.13 \\
.02\end{array}$ & $\begin{array}{l}176 \\
170 \\
162\end{array}$ & $\begin{array}{l}45,000 \\
19,700 \\
<1\end{array}$ \\
\hline 21 & $\begin{array}{l}\text { Maximum } \\
\text { MEAN } \\
\text { Minimum }\end{array}$ & $\begin{array}{l}9.0 \\
8.1 \\
7.4\end{array}$ & $\begin{array}{l}16.20 \\
9.86 \\
5.23\end{array}$ & $\begin{array}{l}203.7 \\
106.3 \\
60.1\end{array}$ & $\begin{array}{l}320 \\
280 \\
240\end{array}$ & $\begin{array}{r}27.6 \\
16.3 \\
.0\end{array}$ & $\begin{array}{l}6.2 \\
2.3 \\
.8\end{array}$ & $\begin{array}{l}74 \\
44 \\
34\end{array}$ & $\begin{array}{l}77.0 \\
9.0 \\
7.5\end{array}$ & $\begin{array}{l}.60 \\
.53 \\
.44\end{array}$ & $\begin{array}{l}5.6 \\
5.0 \\
4.3\end{array}$ & $\begin{array}{l}1.2 \\
.9 \\
.8\end{array}$ & $\begin{array}{l}270 \\
107 \\
88\end{array}$ & $\begin{array}{l}56 \\
49 \\
32\end{array}$ & $\begin{array}{r}11 \\
9.5 \\
7.9\end{array}$ & .2 & $\begin{array}{r}4.5 \\
.6 \\
.0\end{array}$ & $\begin{array}{l}.06 \\
.01 \\
.00\end{array}$ & $\begin{array}{l}.49 \\
.07\end{array}$ & $\begin{array}{r}1.40 \\
.19 \\
.00\end{array}$ & $\begin{array}{l}3.40 \\
.39 \\
.02\end{array}$ & $\begin{array}{l}.47 \\
.12 \\
.00\end{array}$ & $\begin{array}{l}282 \\
173 \\
143\end{array}$ & $\begin{array}{c}178,000 \\
14,200 \\
<1\end{array}$ \\
\hline $\begin{array}{l}\text { Total } \\
\text { Lake }\end{array}$ & $\begin{array}{l}\text { Maximum } \\
\text { MEAN } \\
\text { Manimum } \\
\text { Maximum } \\
\text { MEAN } \\
\text { Minifilim }\end{array}$ & $\begin{array}{l}9.4 \\
8.5 \\
7.6 \\
9.4 \\
8.1 \\
7.2\end{array}$ & $\begin{array}{r}15.85 \\
9.79 \\
5.76 \\
18.03 \\
9.69 \\
5.23\end{array}$ & $\begin{array}{r}206.1 \\
112.8 \\
67.8 \\
206.1 \\
107.0 \\
56.7\end{array}$ & $\begin{array}{l}285 \\
266 \\
230 \\
350 \\
275 \\
75\end{array}$ & $\begin{array}{r}28.8 \\
18.8 \\
\begin{array}{c}28.8 \\
19.1 \\
.0\end{array}\end{array}$ & $\begin{array}{l}5.6 \\
2.5 \\
\frac{.2}{6.2} \\
2.1 \\
.0\end{array}$ & $\begin{array}{l}41 \\
37 \\
\frac{32}{74} \\
38 \\
12\end{array}$ & $\begin{array}{r}9.5 \\
8.5 \\
7.3 \\
17.0 \\
8.6 \\
3.5\end{array}$ & $\begin{array}{l}.55 \\
.5 ! \\
.39 \\
.6 ! \\
.46 \\
.01\end{array}$ & $\begin{array}{l}5.8 \\
4.9 \\
4.3 \\
7.1 \\
4.9 \\
2.1\end{array}$ & $\begin{array}{l}3.6 \\
1.0 \\
.8 \\
1.6 \\
.9 \\
.3\end{array}$ & $\begin{array}{r}107 \\
97 \\
772 \\
270 \\
99 \\
38\end{array}$ & $\begin{array}{l}52 \\
47 \\
39 \\
60 \\
48 \\
11\end{array}$ & $\begin{array}{l}10 \\
9.3 \\
\frac{8.3}{81} \\
\begin{array}{c}11 \\
9.0 \\
3.5\end{array}\end{array}$ & $\begin{array}{l}.2 \\
.1 \\
.0 \\
.4 \\
.1 \\
.0\end{array}$ & $\begin{array}{l}.6 \\
.2 \\
\frac{.00}{5.1} \\
.4 \\
.0\end{array}$ & $\begin{array}{r}.02 \\
.01 \\
.00 \\
.22 \\
.01 \\
.00\end{array}$ & $\begin{array}{r}.79 \\
.12 \\
.00 \\
1.50 \\
.12 \\
.00\end{array}$ & $\begin{array}{r}1.50 \\
.22 \\
.00 \\
1.50 \\
.16 \\
.00\end{array}$ & $\begin{array}{r}1.50 \\
.34 \\
.06 \\
.50 \\
.34 \\
.00\end{array}$ & $\begin{array}{r}.42 \\
.11 \\
.00 \\
1.01 \\
.12 \\
.00\end{array}$ & $\begin{array}{r}170 \\
161 \\
141 \\
282 \\
163 \\
57\end{array}$ & $\begin{array}{r}107,000 \\
18,700 \\
1 \\
\begin{array}{c}201,900 \\
13,600 \\
<1\end{array}\end{array}$ \\
\hline
\end{tabular}



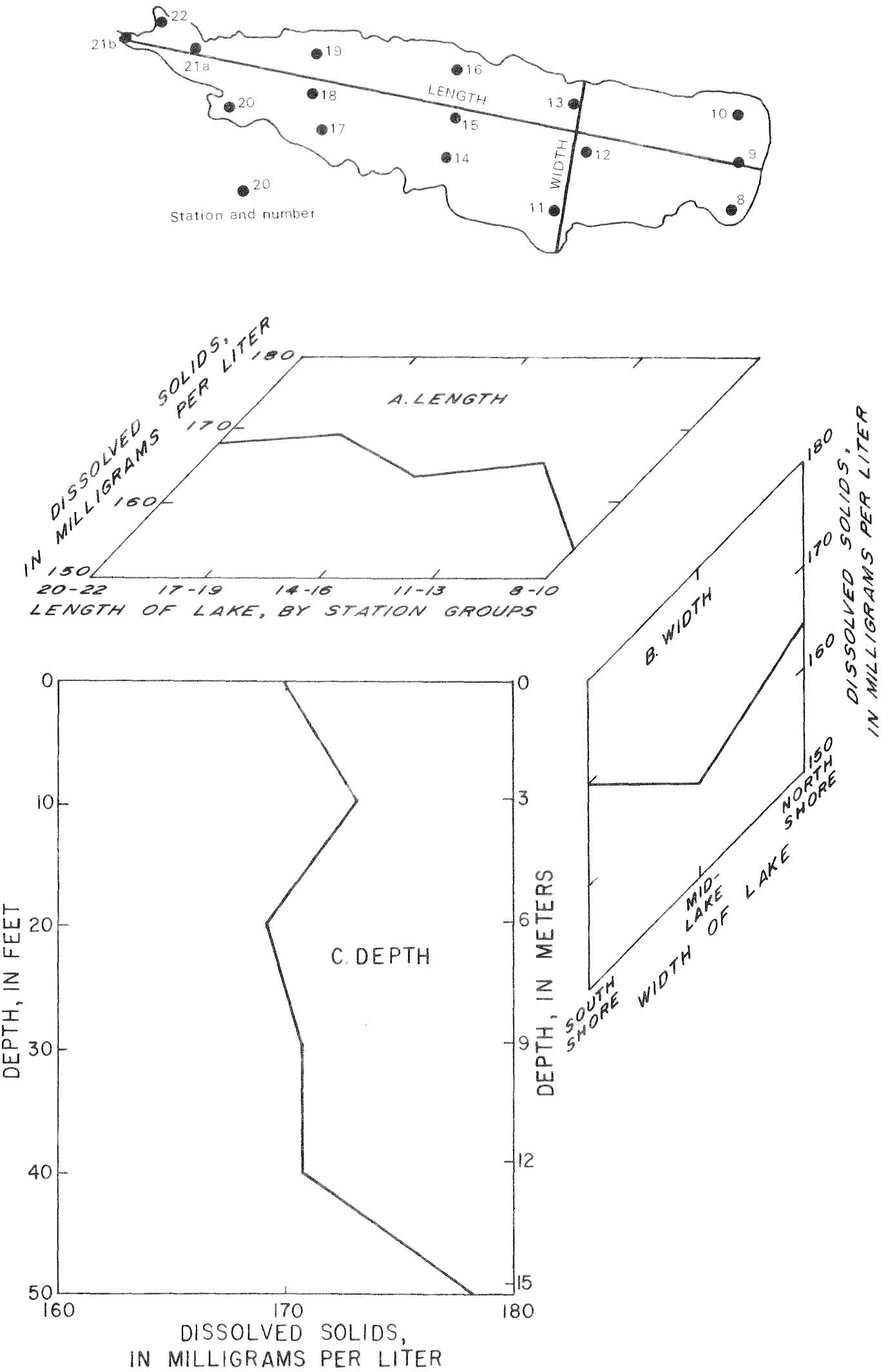

Figure 41.--Spatial variations of dissolved-solids content of Oneida Lake, May 1967 through August 1968. 
Dissolved-oxygen stratification had no effect on the vertical distribution of dissolved solids (table 14). Because there were no appreciable vertical variations, chemical reduction in the lower layers of water during the study was most likely of minor significance. Larger amounts of silicon dioxide $\left(\mathrm{SiO}_{2}\right)$, ammonium ion $\left(\mathrm{NH}_{4}{ }^{+1}\right)$, and total phosphate ion $\left(\mathrm{PO}_{4}{ }^{-3}\right)$ were noted in the deep zone. Increased amounts of these three chemical constituents were probably due to bacterial and biochemical decomposition of organic materials.

\section{Temporal Differences}

Because hydrologic equilibrium of Oneida Lake primarily depended on inflow of water from its tributarles, quality of the lake water was related to quality of the inflowing water. The individual concentration of most dissolved substances in the tributary streams varied inversely with the amount of discharge. When the discharge of water was high, the concentration of dissolved substances was low. This condition resulted from dilution by overland runoff that had a lower dissolved-solids content. The highest dissolved-solids content of a stream occurred in periods of low flow.

Because of the short flow-through time (or retention time) of Oneida Lake, the dissolved-solids content of the lake fluctuated seasonally with amount of surface-water inflow. Mean concentrations of individual chemical constituents in the lake were minimal during winters, spring runoffs, and periods of displacement under ice cover. The largest mean concentrations occurred during dry months. Mean monthly concentrations of various chemical constituents, phytoplankton, and dissolved-solids content of oneida Lake are plotted on figures 42 and 43 . Mean monthly water temperature of the lake is plotted in figure 42.

Figure $42 \mathrm{C}$ shows that the dissolved-solids content of the lake was lowest in December 1967 and March 1969. The mean values were 113 and 103 $\mathrm{mg} / \mathrm{l}$, respectively. The highest mean values of 175 and $171 \mathrm{mg} / 1$ occurred in November 1967 and 1968, respectively.

Individual concentrations of dissolved substances in Oneida Lake varied not only monthly with changes in inflow but also annually with changes in the annual water budget. As indicated in the section, "Water Resources, "the total amount of water flowing through the system in the 1967 water year (that is, October 1966 through September 1967) was 23.9 percent below the long-term average. In the comparable period 1967-68, the total amount of water was 10.8 percent above the long-term average. The dissolved-solids content of the lake varied inversely with streamflow.

In the growing season (June through September) of 1967, dissolvedsolids content of the lake averaged $171 \mathrm{mg} / 1$. In the wetter growing season of 1968 , dissolved-solids content averaged $161 \mathrm{mg} / 1$. Even though routinely collected data are not avallable for the growing season of 1969, a wet year, the mean dissolved-solids content of 6 specially collected samples was 162 $\mathrm{mg} / 1$.

Concentrations of most major ionic constituents in Oneida Lake varied proportionally with changes in the dissolved-solids content. Sodium ( $\mathrm{Na})$ was the only nutrient whose concentration was consistently below the 


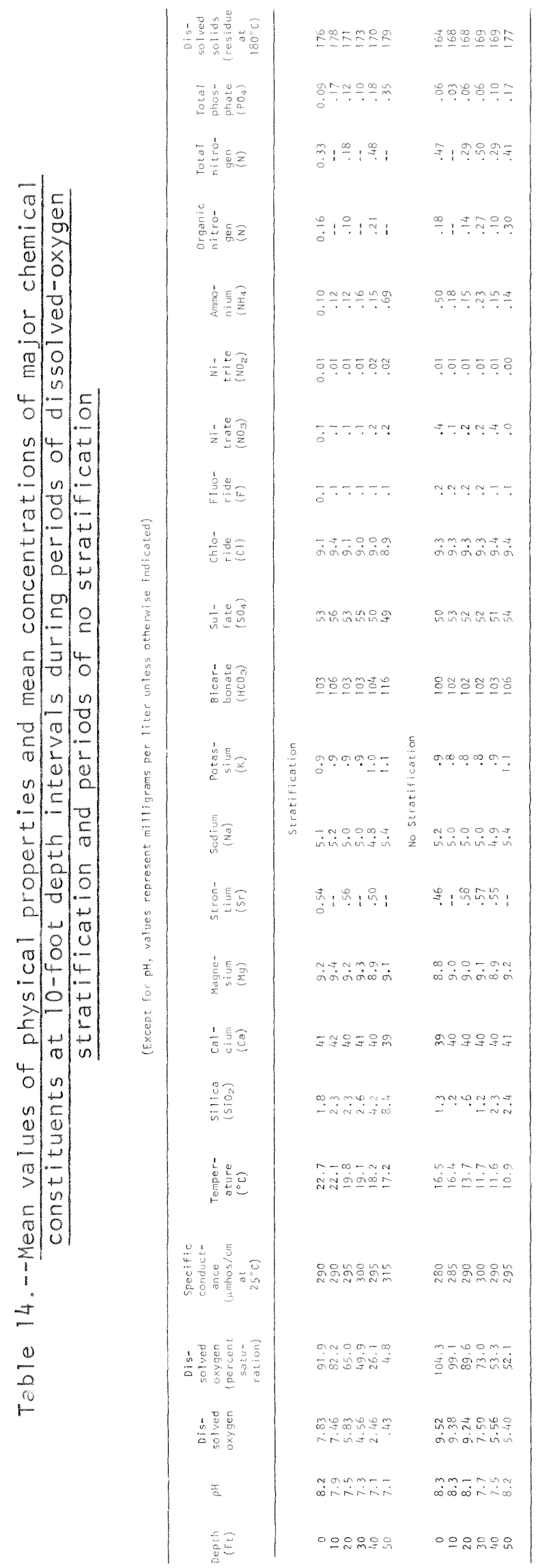



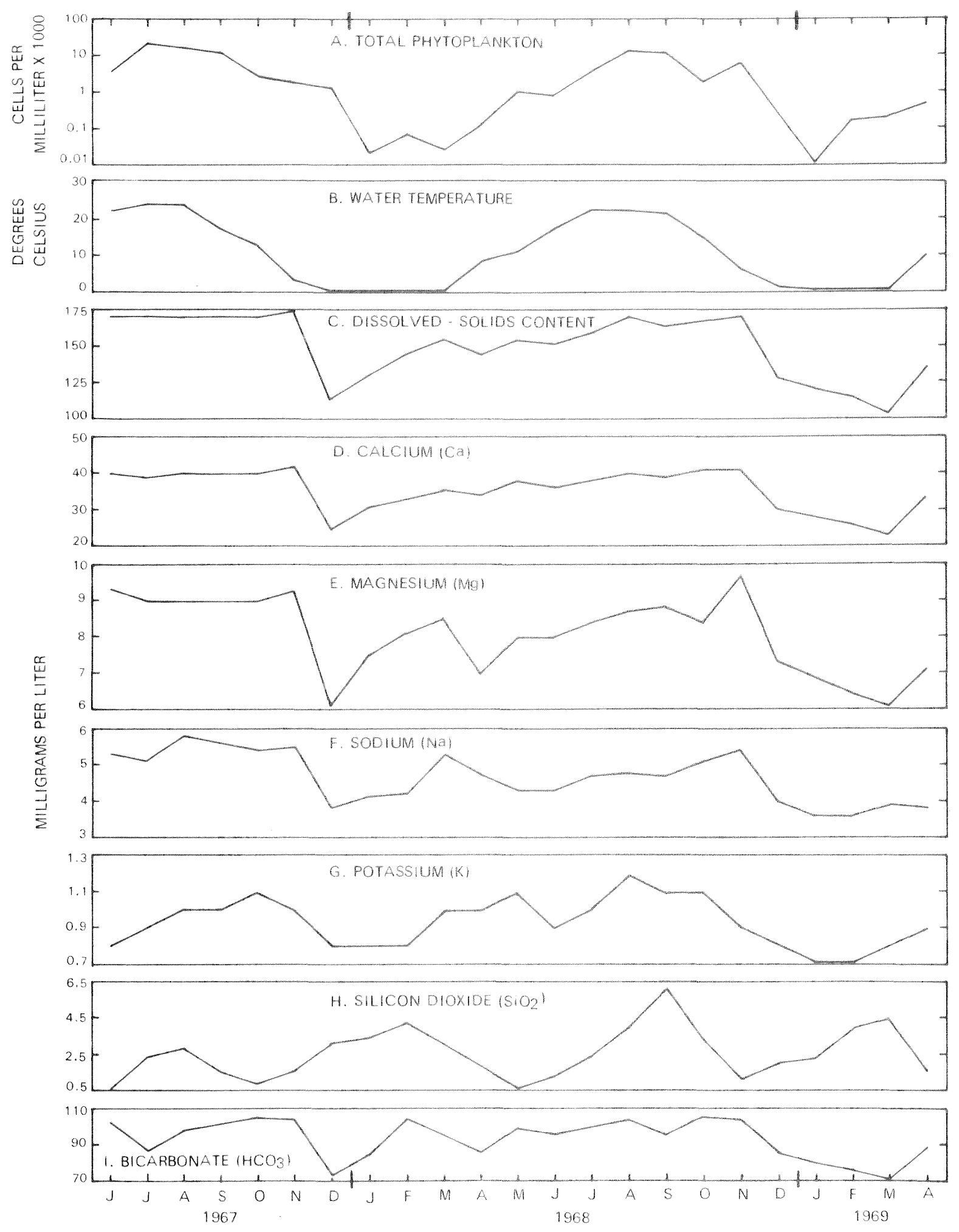

Figure 42.--Mean monthly values for various biological, chemical, and physical parameters, Oneida Lake, June 1967 through April 1969. 

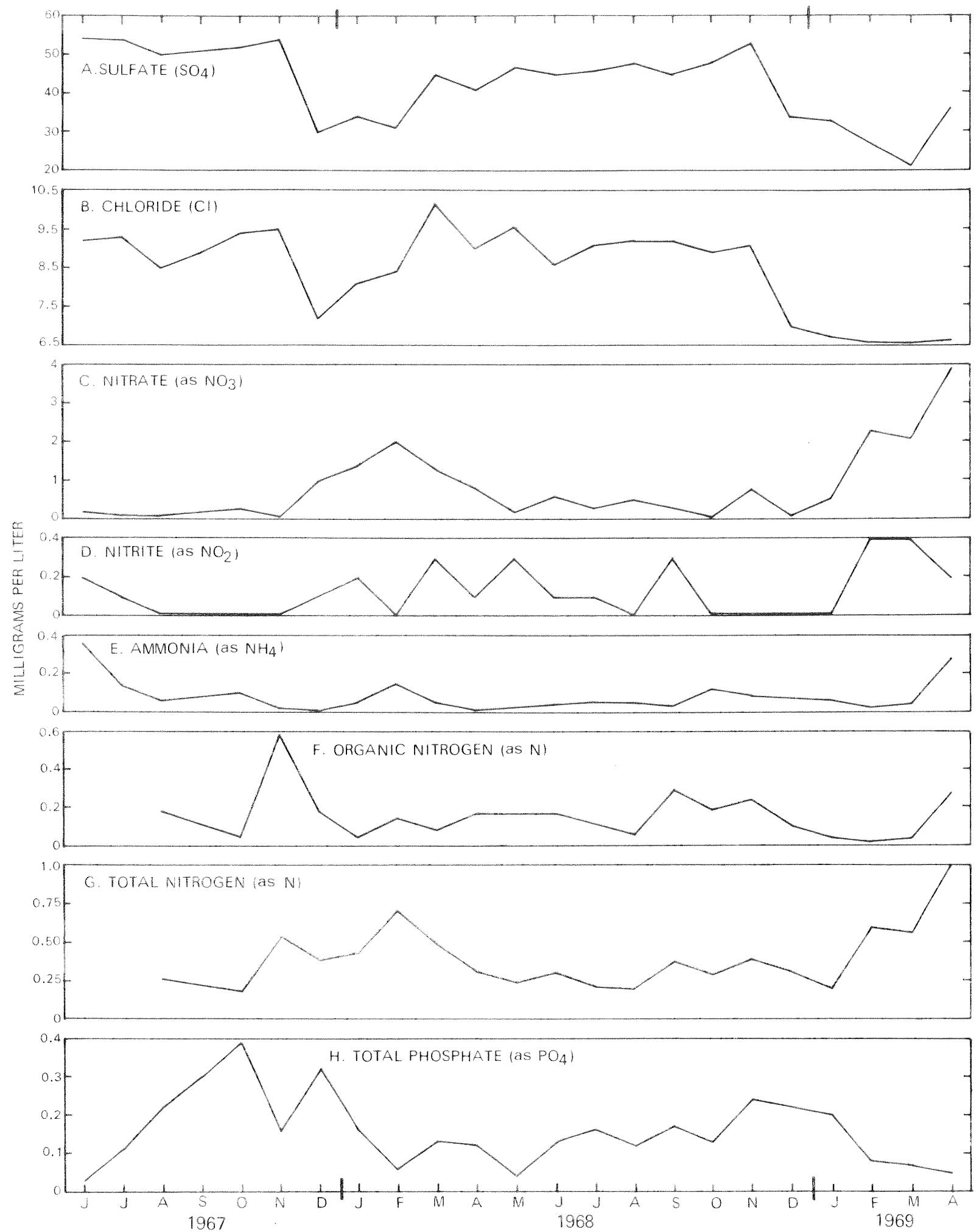

Figure 43. - Mean monthly concentration of selected chemical constituents, Oneida Lake, June 1967 through April 1969. 
estimated minimum requirement of $5.0 \mathrm{mg} / 1$ necessary for heal thy existence of algae. (See table 12.) During the growing seasons 1967, 1968, and 1969, sodium concentrations averaged $5.4,4.6$, and $4.8 \mathrm{mg} / 1$, respectively.

Average values of total phosphate far exceeded the minimum nutritional requirement of $0.01 \mathrm{mg} / \mathrm{l}$ indicated by Sawyer (1949). Total phosphate averaged $0.16,0.14$, and $0.13 \mathrm{mg} / 1$ in 1967, 1968, and 1969, respectively.

Mean concentration of total nitrogen, however, was below the minimum requirement of $0.3 \mathrm{mg} / \mathrm{l}$ (Sawyer, 1947) in the growing seasons of 1967 and 1968. Mean concentrations were 0.24 and $0.27 \mathrm{mg} / 1$, respectively. In the summer of 1969, the mean concentration of total nitrogen was $0.42 \mathrm{mg} / \mathrm{l}$ in the 6 samples mentioned earlier. The higher concentration during 1969 probably resulted from nitrogen-fixation by the abundant blue-green algae.

Long-term chemical varlations.--The earliest reported investigation of Oneida Lake appeared in the annual report of the New York State Board of Health in 1888. The recorded observations were made in the summers of 1885 and 1886 by S. A. Lattimore, who measured several chemical and physical parameters of the lake water. The parameters included color, chloride, ammonia, total solids, loss on ignition, mineral matter, and hardness of water.

Due to changes and improvements in analytical methods since the time of S. A. Lattimore's visits to Oneida Lake, only chloride and hardness of water can be used as parameters for comparison with data collected during the current study. Table 15 shows that the chloride content of Oneida Lake during 1885 and 1886 averaged 4.2 and $3.0 \mathrm{mg} / 1$, respectively. These data were based on the contents of 10 samples. In the current study, chloride content in the lake averaged $9.0 \mathrm{mg} / 1$ but ranged from 3.5 to $11 \mathrm{mg} / 1$.

In 1886, the reported hardness of water of Oneida Lake was $84 \mathrm{mg} / 1$. in 1967-69, it averaged $124 \mathrm{mg} / 1$ and ranged from 38 to $150 \mathrm{mg} / 1$.

It is difficult to assess the apparent changes in chloride concentration and hardness during the past 83 years because of sparsity of data collected during 1885 and 1886 and because of the lack of knowledge of the overall environmental conditions during the early perlod. However, chloride content and hardness of water of Oneida Lake have probably increased during the period of record.

Mean values in table 15 represent samples collected from the surface of Oneida Lake in an 85 -year period. Mean concentrations were used to deemphasize extreme values, to deemphasize geographical or areal variations, and to provide single values for comparison. Samples collected from the lake outlet at Brewerton represent the chemical conditions in Oneida Lake, and, therefore, data from that location were included when computing the mean values.

Wagner (1928) reported that in 1927 the alkalinity concentrations of oneida Lake off cleveland ranged from 9.7 to $19.8 \mathrm{mg} / 1$. At a depth of 49 feet (15 meters), Wagner reported that alkalinity ranged from 11.9 to 31.7 $\mathrm{mg} / \mathrm{l}$. During the same year, he reported that the alkalinity concentration at Brewerton was $78 \mathrm{mg} / 1$. Mean alkalinity for Wagner's six surface samples was $46 \mathrm{mg} / 1$. 


$$
\begin{aligned}
& \text { Table 15.--Long-term mean variations of selected chemical constituents } \\
& \text { and properties of Oneida Lake } \\
& \text { (Chemical data in milligrams per liter) }
\end{aligned}
$$

\begin{tabular}{|c|c|c|c|c|c|c|}
\hline Year & $\begin{array}{l}\text { Alkalinity } \\
\left(\text { as } \mathrm{CaCO}_{3}\right)\end{array}$ & chloride & $\begin{array}{l}\text { Hardness } \\
\left(\text { as } \mathrm{CaCO}_{3}\right)\end{array}$ & $\begin{array}{c}\text { Total } \\
\text { phosphate }\end{array}$ & $\begin{array}{c}\text { Number of } \\
\text { samples }\end{array}$ & Reference \\
\hline 1885 & - & 4.2 & - & - & 8 & 1 \\
\hline 1886 & $\cdots$ & 3.0 & 84 & -- & 2 & 1 \\
\hline 227 & 78 & -- & -- & -- & 6 & 2 \\
\hline 1946 & 74 & -- & -- & 0.11 & 11 & 3 \\
\hline 1954 & 84 & $-\infty$ & -- & -- & 15 & 4 \\
\hline 1956 & 77 & 5.5 & 128 & -- & 9 & 5 \\
\hline 1961 & 86 & 13 & 145 & .21 & 116 & 6 \\
\hline $1964-66$ & 83 & -- & -. & .35 & 324 & 7 \\
\hline \multicolumn{7}{|l|}{$1967-69$} \\
\hline $\begin{array}{l}\text { Mean } \\
\text { Maximum } \\
\text { Minimum }\end{array}$ & $\begin{array}{r}81 \\
221 \\
31\end{array}$ & $\begin{array}{l}9.0 \\
11 \\
3.5\end{array}$ & $\begin{array}{r}124 \\
150 \\
58\end{array}$ & $\begin{array}{l}.12 \\
1.0 \\
.0\end{array}$ & $>425$ & 8 \\
\hline
\end{tabular}

References:

1. New York Stace Board of Health, 1888.

2. Wagner, 1928.

3. Burdick and Lisclidetz, 1946.

4. Dence and Jackson, 1959.

5. New York State Dept. of Health, 1957.

6. Mt. Pleasant and others, 1961.

7. M. C. Lehne, Onondaga County Dept. of Public Works, written commun.

8. Current study.

The author questions the validity of Wagner's data reported in 1928 because the water flowing past Brewerton is lake water, and its chemical constituents are the same as those in the lake proper. Furthermore, differences reported between surface and bottom alkalinities at the location off cleveland are extremely large for a lake that is well mixed and that does not thermally stratify; therefore, alkalinity reported for Brewerton (78 ng/1) probably approximated true alkalinity of Oneida Lake during 1927. 
Assuming that $78 \mathrm{mg} / 1$ was the approximate alkalinity in Wagner's study, table 15 indicates that no significant change occurred in the alkalinity of Oneida Lake during the period 1927-69. Subtle differences in alkalinity reported by various investigators result from variations of enivronmental conditions (for example, the amount of water inflow from the drainage basin) during periods of sample collection, number and frequency of samples collected, and analytical errors.

\section{Chemical Values of Oneida Lake}

Concentrations of 25 trace metals in Oneida Lake are given in table 16. Variations in concentrations of the metals generally were minimal, and no significance could be placed on fluctuations.

In Oneida Lake, all but four metals essential to the growth of algae occurred in quantities adequate for algal nutrition. Mean annual concentrations of copper (Cu) and manganese (Mn) fluctuated above and below the estimated minimum requirements of 0.006 and $0.005 \mathrm{mg} / 1$, respectively. Mean annual concentrations of boron (B) and cobalt (Co) were considerably below the estimated minimums of 0.1 and $0.5 \mathrm{mg} / 1$, respectively.

The mean concentration of copper in Onelda Lake was $0.007 \mathrm{mg} / 1$, slightly above the reported minimum requirement. Mean concentration was 0.007 $\mathrm{mg} / 1$ in the growing season of 1968. In the growing seasons of 1967 and 1969, concentration of copper averaged $0.005 \mathrm{mg} / 1$.

Mean annual concentrations of manganese were generally above the reported essential minimum values. During the study the mean was $0.016 \mathrm{mg} / 1$. only during the growing season of 1968 did the concentration average below the minimum requirement: it was $0.004 \mathrm{mg} / 1$.

Concentrations of boron and cobalt never approached the estimated minimum requirements for algal nutrition. The concentrations were about 0.024 and less than $0.005 \mathrm{mg} / 1$, respectively. These low concentrations of the two metals had no perceptible effect on phytoplankton production.

Because of increased concern during the spring of 1970 over mercury contamination in natural water, dissolved mercury content of four specially collected samples from Oneida Lake and vicinity was determined. Locations of sample collections and respective dissolved mercury contents, in micrograms per liter, were as follows: Oneida River at Caughdenoy, <0.1; Oneida Lake at Brewerton, 0.2; Oneida Lake at Sylvan Beach, <0.1; and Chittenango Creek at Bridgeport, 0.1 . The concentrations of dissolved mercury were well within the safe limits for any use of the lake and its water. They probably reflected a natural background level.

Concentrations of most pesticides in both water and sediment samples from two locations on Oneida Lake on october 1, 1969, were below the detection limit. Concentrations of eight chlorinated hydrocarbon insecticides and three herbicides in water and the sediment are given in table 17. 
Mean concentrations of dissolved chemical constituents at the surface of Oneida Lake from May 1967 through october 1969 are given in table 18. Elements and compounds essential to production of algae are indicated by footnote 1 of the table.

of those studied, no particular element, ion, or compound seemed to be a limiting factor on the bodily processes of algae or on the extent of bloom formation in Oneida Lake. Even during the large blooms of the growing seasons of 1967 and especially of 1969, mean concentrations of most dissolved nutrients were above the estimated minimum requirements for the healthy existence of phytoplankton. Variations in concentrations of discolved nutrients could not be correlated with changes in phytoplankton populations. 
Table 16.--Concentrations of trace metals in Oneida Lake

(Samples were collected from the surface at station 12 and values ropresent micrograms per 1iter. WD means not determined)

\begin{tabular}{|c|c|c|c|c|c|c|c|c|c|c|c|c|c|c|c|c|c|c|c|c|c|c|c|c|c|}
\hline Date & $\begin{array}{l}\text { Alumi- } \\
\text { num } \\
(A 1)^{1}\end{array}$ & $\begin{array}{c}\text { Barium } \\
\text { (Ba) }\end{array}$ & $\begin{array}{c}\text { Bery'- } \\
\text { I i Liry } \\
\text { (Be) }\end{array}$ & $\begin{array}{l}\text { Bis- } \\
\text { muth } \\
\text { (Bi) }\end{array}$ & $\begin{array}{c}\text { Baron } \\
(B)^{2}\end{array}$ & $\begin{array}{l}c=d- \\
m i(u m) \\
(c d)\end{array}$ & $\begin{array}{l}\text { chro- } \\
\text { mium } \\
(c r)\end{array}$ & $\begin{array}{l}\text { Cobalt } \\
\left(\operatorname{Co}^{1}\right)^{1}\end{array}$ & $\begin{array}{l}\text { Copper } \\
(C u)^{r}\end{array}$ & $\begin{array}{l}G=1- \\
\substack{i u m \\
(G a\rangle}\end{array}$ & $\begin{array}{l}\text { Germa- } \\
\text { nium } \\
\text { (Ge) }\end{array}$ & $\begin{array}{l}\text { lron } \\
(\mathrm{Fe})^{2}\end{array}$ & $\begin{array}{l}\text { Lead } \\
(p b)\end{array}$ & $\begin{array}{l}\text { Lith- } \\
\text { itum } \\
\text { thi }\end{array}$ & $\begin{array}{c}\text { Manga- } \\
\text { nese } \\
(M i n)^{3}\end{array}$ & $\begin{array}{l}\text { Molyb- } \\
\text { denum } \\
\text { Mo }\end{array}$ & $\begin{array}{c}\text { Nichel } \\
(\text { Ni }\end{array}$ & $\begin{array}{c}\text { Rubid- } \\
\vdots: m b \\
(R b)\end{array}$ & $\begin{array}{l}\text { silver } \\
\text { (As })\end{array}$ & $\begin{array}{l}\text { stron- } \\
\text { tium } \\
\text { (st) }\end{array}$ & $\operatorname{Tin}$ & $\begin{array}{l}\text { Tita- } \\
\text { nump } \\
\text { (Ti) }\end{array}$ & $\begin{array}{l}\text { Vand- } \\
\text { dium? } \\
\text { (v)? }\end{array}$ & $\begin{array}{l}z i n c \\
(z n)^{2}\end{array}$ & $\begin{array}{l}\text { zirco- } \\
\text { gium } \\
\text { (zr) }\end{array}$ \\
\hline $\begin{array}{l}5-29-67 \\
6-6-67 \\
6-13-67 \\
6-20-67 \\
6-27-67\end{array}$ & $\begin{array}{l}45 \\
70 \\
30 \\
40 \\
41\end{array}$ & $\begin{array}{l}35 \\
33 \\
31 \\
31 \\
34\end{array}$ & $\begin{array}{r}<0.2 \\
<.2 \\
<.2 \\
<.2 \\
<.2\end{array}$ & $\begin{array}{l}\text { ND } \\
\text { ND } \\
\text { ND } \\
\text { ND } \\
\text { ND }\end{array}$ & $\begin{array}{l}30 \\
19 \\
22 \\
14 \\
22\end{array}$ & $\begin{array}{l}\text { ND } \\
N D \\
N D \\
N D \\
N D\end{array}$ & $\begin{array}{r}1 \\
9 \\
9 \\
14 \\
7\end{array}$ & $\begin{array}{l}<2 \\
<3 \\
<3 \\
<3 \\
<3\end{array}$ & $\begin{array}{l}3 \\
5 \\
4 \\
7 \\
5\end{array}$ & $\begin{array}{l}\text { ND } \\
\text { ND } \\
\text { ND } \\
\text { ND } \\
\text { ND }\end{array}$ & $\begin{array}{l}\text { ND } \\
\text { ND } \\
\text { ND } \\
\text { ND } \\
\text { ND }\end{array}$ & $\begin{array}{l}35 \\
70 \\
11 \\
14 \\
20\end{array}$ & $\begin{array}{r}<2 \\
8 \\
22 \\
7 \\
5\end{array}$ & $\begin{array}{l}3 \\
4 \\
4 \\
4 \\
3\end{array}$ & $\begin{array}{r}5 \\
13 \\
13 \\
9 \\
95\end{array}$ & $\begin{array}{r}<0.5 \\
<.6 \\
<.6 \\
<.6 \\
<.6\end{array}$ & $\begin{array}{l}<2 \\
.9 \\
<.6 \\
<.6 \\
<.6\end{array}$ & $\begin{array}{l}<1 \\
<1 \\
<1 \\
<2\end{array}$ & $\begin{array}{r}<0.2 \\
<.2 \\
8.2 \\
<.2 \\
<.2\end{array}$ & $\begin{array}{l}500 \\
530 \\
490 \\
540 \\
560\end{array}$ & $\begin{array}{r}<2 \\
2 \\
9 \\
<2 \\
<2\end{array}$ & $\begin{array}{l}2 \\
3 \\
.3 \\
.6 \\
.6\end{array}$ & $\begin{array}{r}<2 \\
3 \\
3 \\
3 \\
3\end{array}$ & $\begin{array}{l}<25 \\
<20 \\
20 \\
20 \\
20\end{array}$ & $\begin{array}{l}N D \\
N D \\
N D \\
N D \\
N D\end{array}$ \\
\hline $\begin{array}{l}6-29-67 \\
7-1-67 \\
7-3-67 \\
7-6-67 \\
7-10-67\end{array}$ & $\begin{array}{l}43 \\
28 \\
60 \\
13 \\
54\end{array}$ & $\begin{array}{l}32 \\
35 \\
34 \\
35 \\
40\end{array}$ & $\begin{array}{l}<.2 \\
<.2 \\
<.2 \\
<.2 \\
<.2\end{array}$ & $\begin{array}{l}\text { ND } \\
\text { ND } \\
\text { ND } \\
\text { ND } \\
\text { ND }\end{array}$ & $\begin{array}{l}18 \\
26 \\
21 \\
26 \\
25\end{array}$ & $\begin{array}{l}\text { ND } \\
\text { ND } \\
\text { ND } \\
\text { ND } \\
\text { ND }\end{array}$ & $\begin{array}{r}13 \\
12 \\
8 \\
8 \\
12\end{array}$ & $\begin{array}{l}<3 \\
<3 \\
<3 \\
<3 \\
<3\end{array}$ & $\begin{array}{r}3 \\
10 \\
6 \\
4 \\
4\end{array}$ & $\begin{array}{l}\text { ND } \\
\text { ND } \\
\text { ND } \\
\text { ND } \\
\text { ND }\end{array}$ & $\begin{array}{l}\text { ND } \\
\text { ND } \\
\text { ND } \\
\text { ND } \\
N D\end{array}$ & $\begin{array}{r}8 \\
20 \\
65 \\
6 \\
33\end{array}$ & $\begin{array}{r}7 \\
6 \\
4 \\
19 \\
9\end{array}$ & $\begin{array}{l}4 \\
3 \\
3 \\
3 \\
3 \\
4\end{array}$ & $\begin{array}{r}4 \\
8 \\
7 \\
3 \\
14\end{array}$ & $\begin{array}{l}<.6 \\
<.6 \\
<.6 \\
<.6 \\
<.6\end{array}$ & $\begin{array}{l}<.6 \\
<.6 \\
<.6 \\
<.6 \\
<.6\end{array}$ & $\begin{array}{l}<2 \\
<1 \\
<1 \\
<1\end{array}$ & $\begin{array}{r}<.2 \\
.2 \\
.2 \\
.2 \\
.2\end{array}$ & $\begin{array}{l}540 \\
600 \\
590 \\
570 \\
550\end{array}$ & $\begin{array}{r}<2 \\
2 \\
<2 \\
10 \\
2\end{array}$ & $\begin{array}{l}.4 \\
.2 \\
.7 \\
.3 \\
.5\end{array}$ & $\begin{array}{l}8 \\
<3 \\
3 \\
3 \\
3 \\
3\end{array}$ & $\begin{array}{l}<20 \\
<20 \\
<20 \\
<20 \\
<20\end{array}$ & $\begin{array}{l}\mathrm{NO} \\
\mathrm{NO} \\
\mathrm{NO} \\
\mathrm{NO}\end{array}$ \\
\hline $\begin{array}{l}7-14-67 \\
7-18-67 \\
7-27-67 \\
8-1-67 \\
8-10-67\end{array}$ & $\begin{array}{l}41 \\
28 \\
30 \\
23 \\
60\end{array}$ & $\begin{array}{l}35 \\
30 \\
31 \\
32 \\
31\end{array}$ & $\begin{array}{l}<.2 \\
<.2 \\
<.2 \\
<.2 \\
<.2\end{array}$ & $\begin{array}{l}\text { ND } \\
\text { ND } \\
\text { ND } \\
\text { ND } \\
\text { ND }\end{array}$ & $\begin{array}{l}27 \\
25 \\
26 \\
31 \\
25\end{array}$ & $\begin{array}{l}\text { ND } \\
\text { ND } \\
\text { ND } \\
\text { ND } \\
\text { ND }\end{array}$ & $\begin{array}{r}21 \\
12 \\
8 \\
8 \\
10\end{array}$ & $\begin{array}{l}<3 \\
<3 \\
<3 \\
<3 \\
<3\end{array}$ & $\begin{array}{r}4 \\
14 \\
3 \\
5 \\
5\end{array}$ & $\begin{array}{l}\text { ND } \\
\text { ND } \\
\text { ND } \\
\text { ND } \\
\text { ND }\end{array}$ & $\begin{array}{l}\text { ND } \\
\text { ND } \\
\text { ND } \\
\text { ND } \\
\text { ND }\end{array}$ & $\begin{array}{r}55 \\
110 \\
45 \\
18 \\
75\end{array}$ & $\begin{array}{l}7 \\
9 \\
3 \\
5 \\
5\end{array}$ & $\begin{array}{l}4 \\
3 \\
3 \\
4 \\
3\end{array}$ & $\begin{array}{r}16 \\
25 \\
8 \\
8 \\
--\end{array}$ & $\begin{array}{l}<.6 \\
<.6 \\
<.6 \\
<.6 \\
<.6\end{array}$ & $\begin{array}{r}1 \\
1 \\
.7 \\
.8 \\
.8\end{array}$ & $\begin{array}{l}<1 \\
<1 \\
<1 \\
<1\end{array}$ & $\begin{array}{r}<.2 \\
.2 \\
<.2 \\
<.2 \\
<.2\end{array}$ & $\begin{array}{l}550 \\
550 \\
550 \\
590 \\
530\end{array}$ & $\begin{array}{r}<2 \\
4 \\
<2 \\
<2 \\
<2\end{array}$ & $\begin{array}{l}1 \\
2.7 \\
.9 \\
.4\end{array}$ & $\begin{array}{l}<3 \\
3 \\
3 \\
<3 \\
<3\end{array}$ & $\begin{array}{r}20 \\
<20 \\
<20 \\
22\end{array}$ & $\begin{array}{l}\text { ND } \\
\text { No } \\
\text { No } \\
\text { No } \\
\text { No }\end{array}$ \\
\hline $\begin{array}{l}8-18-67 \\
8-22-67 \\
9-27-67 \\
10-9-67 \\
10-14-67\end{array}$ & $\begin{array}{r}13 \\
18 \\
50 \\
100 \\
30\end{array}$ & $\begin{array}{l}35 \\
38 \\
30 \\
40 \\
33\end{array}$ & $\begin{array}{l}<.6 \\
<.6 \\
<.6 \\
<.2 \\
<.1\end{array}$ & $\begin{array}{l}\text { ND } \\
\text { ND } \\
\text { ND } \\
<3 \\
<3\end{array}$ & $\begin{array}{l}34 \\
30 \\
20 \\
25 \\
20\end{array}$ & $\begin{array}{l}N D \\
N D \\
N D \\
N D \\
<2 \\
<15\end{array}$ & $\begin{array}{r}3 \\
5 \\
6 \\
50 \\
13\end{array}$ & $\begin{array}{l}<3 \\
<3 \\
<3 \\
<2 \\
<2\end{array}$ & $\begin{array}{r}3 \\
4 \\
11 \\
6 \\
5\end{array}$ & $\begin{array}{l}\text { ND } \\
\text { ND } \\
\text { ND } \\
<2 \\
<2 \\
<2\end{array}$ & $\begin{array}{l}\text { ND } \\
\text { ND } \\
\text { ND } \\
\text { ND } \\
\text { ND }\end{array}$ & $\begin{array}{r}45 \\
9 \\
9 \\
260 \\
70\end{array}$ & $\begin{array}{r}18 \\
3 \\
2 \\
3 \\
12\end{array}$ & $\begin{array}{l}4 \\
4 \\
3 \\
3 \\
3\end{array}$ & $\begin{array}{r}17 \\
4 \\
2 \\
5 \\
12\end{array}$ & $\begin{array}{l}<1 \\
<1 \\
<.6 \\
<.6 \\
<.6\end{array}$ & $\begin{array}{r}.9 \\
.7 \\
<.9 \\
2.7 \\
.7\end{array}$ & $\begin{array}{l}<1 \\
<1.8 \\
.9 \\
1\end{array}$ & $\begin{array}{l}<.2 \\
<.2 \\
<.2 \\
<.2 \\
<.2\end{array}$ & $\begin{array}{l}500 \\
510 \\
690 \\
580 \\
430\end{array}$ & $\begin{array}{r}7 \\
2 \\
42 \\
3 \\
3\end{array}$ & $\begin{array}{l}2 \\
4 \\
3 \\
8 \\
2\end{array}$ & $\begin{array}{l}2 \\
2 \\
<2 \\
3 \\
2\end{array}$ & $\begin{array}{r}<15 \\
<15 \\
3 \\
10 \\
12\end{array}$ & $\begin{array}{l}\text { ND } \\
\text { ND } \\
\text { ND } \\
\text { ND }\end{array}$ \\
\hline $\begin{array}{r}10-30-67 \\
12-18-67 \\
1-3-68 \\
2-13-68 \\
2-27-68\end{array}$ & $\begin{array}{l}8 \\
25 \\
20 \\
30 \\
25\end{array}$ & $\begin{array}{l}40 \\
30 \\
-- \\
30 \\
31\end{array}$ & $\begin{array}{l}<.2 \\
<.1 \\
<.1 \\
<.6 \\
<.7\end{array}$ & $\begin{array}{l}<3 \\
<3 \\
N D \\
N D \\
N D\end{array}$ & $\begin{array}{l}24 \\
20 \\
30 \\
40 \\
23\end{array}$ & $\begin{array}{l}<2 \\
<15 \\
N D \\
N D \\
N D\end{array}$ & $\begin{array}{l}1 \\
3 \\
7 \\
4 \\
8\end{array}$ & $\begin{array}{l}<2 \\
<2 \\
<5 \\
<8 \\
<5\end{array}$ & $\begin{array}{l}3 \\
7 \\
10 \\
10 \\
30\end{array}$ & $\begin{array}{l}<2 \\
<2 \\
N D \\
N D \\
\text { ND } \\
\text { ND }\end{array}$ & $\begin{array}{l}\text { ND } \\
\text { ND } \\
\text { ND } \\
\text { ND } \\
\text { ND }\end{array}$ & $\begin{array}{r}4 \\
50 \\
27 \\
110 \\
85\end{array}$ & $\begin{array}{r}8 \\
17 \\
6 \\
10 \\
20\end{array}$ & $\begin{array}{l}4 \\
3 \\
4 \\
4 \\
3\end{array}$ & $\begin{array}{l}2 \\
11 \\
18 \\
95 \\
40\end{array}$ & $\begin{array}{l}<.6 \\
<.6 \\
<.5 \\
<.6 \\
<.5\end{array}$ & $\begin{array}{l}<.6 \\
1 \\
<.6 \\
2 \\
4\end{array}$ & $\begin{array}{l}1.8 \\
.8 \\
.9 \\
.9\end{array}$ & $\begin{array}{r}<.2 \\
<.2 \\
<.5 \\
<.3 \\
<.4\end{array}$ & $\begin{array}{r}660 \\
490 \\
270 \\
350\end{array}$ & $\begin{array}{r}83 \\
33 \\
<8 \\
<5\end{array}$ & $\begin{array}{r}<2 \\
2 \\
5 \\
-2 \\
2\end{array}$ & $\begin{array}{l}3 \\
2 \\
5 \\
1 \\
2\end{array}$ & $\begin{array}{l}15 \\
37 \\
N 0 \\
10 \\
N D\end{array}$ & $\begin{array}{l}\text { No } \\
\text { No } \\
\text { No } \\
\text { No }\end{array}$ \\
\hline $\begin{array}{l}3-13-68 \\
4-18-68 \\
5-5-68 \\
5-9-68 \\
5-28-68\end{array}$ & $\begin{array}{l}28 \\
20 \\
12 \\
25 \\
50\end{array}$ & $\begin{array}{l}33 \\
29 \\
33 \\
31 \\
36\end{array}$ & $\begin{array}{l}<.6 \\
<2 \\
<.8 \\
<2 \\
<.8\end{array}$ & $\begin{array}{l}\text { ND } \\
\text { ND } \\
<2 \\
\text { ND } \\
<2\end{array}$ & $\begin{array}{l}21 \\
17 \\
17 \\
18 \\
17\end{array}$ & $\begin{array}{r}\mathrm{ND} \\
\mathrm{ND} \\
<16 \\
\mathrm{ND} \\
<16\end{array}$ & $\begin{array}{c}5 \\
3 \\
2 \\
5 \\
15\end{array}$ & $\begin{array}{l}<4 \\
<5 \\
<8 \\
<5 \\
<8\end{array}$ & $\begin{array}{l}8 \\
5 \\
8 \\
4 \\
7\end{array}$ & $\begin{array}{l}\text { ND } \\
\text { ND } \\
- \\
\text { ND } \\
\cdots\end{array}$ & $\begin{array}{l}N D \\
N D \\
<4 \\
N D \\
<4\end{array}$ & $\begin{array}{r}70 \\
21 \\
7 \\
17 \\
-\end{array}$ & $\begin{array}{r}9 \\
<3 \\
<4 \\
3 \\
4\end{array}$ & $\begin{array}{l}2 \\
3 \\
3 \\
2 \\
3\end{array}$ & $\begin{array}{r}38 \\
7 \\
7 \\
4 \\
--\end{array}$ & $\begin{array}{l}<.4 \\
<1.8 \\
<.8 \\
<.8\end{array}$ & $\begin{array}{l}2 \\
<5 \\
<5 \\
<5 \\
<5\end{array}$ & $\begin{array}{r}.6 \\
.8 \\
.6 \\
<.5 \\
.6\end{array}$ & $\begin{array}{r}<.3 \\
<.4 \\
<.4 \\
8.4\end{array}$ & $\begin{array}{l}360 \\
420 \\
510 \\
520 \\
530\end{array}$ & $\begin{array}{r}5 \\
5 \\
5 \\
5 \\
5 \\
<5\end{array}$ & 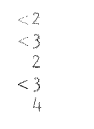 & $\begin{array}{l}<1 \\
<4 \\
<4 \\
<4\end{array}$ & $\begin{array}{r}10 D \\
<20 \\
<160 \\
200 \\
160\end{array}$ & $\begin{array}{l}\text { ND } \\
\text { ND } \\
\text { ND } \\
\text { - }\end{array}$ \\
\hline $\begin{array}{l}6-14-68 \\
7-3-68 \\
7-10-68 \\
7-24-68 \\
7-31-68\end{array}$ & $\begin{array}{l}17 \\
16 \\
24 \\
9 \\
13\end{array}$ & $\begin{array}{l}34 \\
32 \\
31 \\
33 \\
25\end{array}$ & $\begin{array}{l}<.8 \\
<.8 \\
<.8 \\
<.8 \\
<.8\end{array}$ & $\begin{array}{l}<2 \\
<2 \\
<2 \\
\text { ND } \\
\text { ND }\end{array}$ & $\begin{array}{l}17 \\
32 \\
17 \\
18 \\
17\end{array}$ & $\begin{array}{l}<16 \\
<17 \\
<17 \\
\text { ND } \\
\text { ND }\end{array}$ & $\begin{array}{r}3 \\
2 \\
2 \\
<4 \\
<4\end{array}$ & $\begin{array}{l}<8 \\
<8 \\
<8 \\
<8 \\
<8\end{array}$ & $\begin{array}{r}6 \\
6 \\
8 \\
12 \\
7\end{array}$ & $\begin{array}{l}- \\
- \\
- \\
-\end{array}$ & $\begin{array}{l}<4 \\
<4 \\
<4 \\
N D \\
N D\end{array}$ & $\begin{array}{r}8 \\
12 \\
18 \\
4 \\
9\end{array}$ & $\begin{array}{l}<4 \\
7 \\
>4 \\
<4 \\
<4\end{array}$ & $\begin{array}{l}3 \\
4 \\
4 \\
3 \\
3\end{array}$ & $\begin{array}{l}4 \\
1 \\
4 \\
2 \\
5\end{array}$ & $\begin{array}{l}<.8 \\
<.8 \\
<.8 \\
<2 \\
<2\end{array}$ & $\begin{array}{l}<5 \\
<6 \\
<6 \\
<4 \\
<4\end{array}$ & $\begin{array}{l}.7 \\
.9 \\
.8 \\
.7\end{array}$ & $\begin{array}{r}.4 \\
.4 \\
.4 \\
.4 \\
.4\end{array}$ & $\begin{array}{l}580 \\
550 \\
590 \\
570 \\
580\end{array}$ & $\begin{array}{r}8 \\
<6 \\
<6 \\
8 \\
8\end{array}$ & $\begin{array}{r}2 \\
2 \\
3 \\
4 \\
2 \\
2\end{array}$ & $\begin{array}{r}4 \\
4 \\
4 \\
4\end{array}$ & $\begin{array}{r}160 \\
\quad 170 \\
170 \\
8160 \\
160\end{array}$ & $\begin{array}{l}-\cdots \\
\cdots \\
-- \\
\cdots \\
\cdots\end{array}$ \\
\hline $\begin{array}{l}8-6-68 \\
8-20-68 \\
8-28-68 \\
9-12-68 \\
9-24-68\end{array}$ & $\begin{array}{r}12 \\
12 \\
6 \\
22 \\
16\end{array}$ & $\begin{array}{l}29 \\
29 \\
22 \\
31 \\
35\end{array}$ & $\begin{array}{l}<.8 \\
<.8 \\
<.6 \\
<.8 \\
<2\end{array}$ & $\begin{array}{l}<2 \\
<2 \\
<3 \\
<4 \\
<8\end{array}$ & $\begin{array}{l}20 \\
19 \\
22 \\
28 \\
32\end{array}$ & $\begin{array}{r}<16 \\
<16 \\
<30 \\
<16\end{array}$ & $\begin{array}{r}2 \\
<2 \\
<3 \\
6 \\
<6\end{array}$ & $\begin{array}{l}<8 \\
<8 \\
<3 \\
<4 \\
<8\end{array}$ & $\begin{array}{c}5 \\
5 \\
5 \\
4 \\
5 \\
16\end{array}$ & $\begin{array}{l}-- \\
-- \\
-\bar{y} \\
--\end{array}$ & $\begin{array}{l}N D \\
N D \\
N D \\
N D \\
<8\end{array}$ & $\begin{array}{r}9 \\
4 \\
9 \\
33 \\
24\end{array}$ & $\begin{array}{r}9 \\
8 \\
<3 \\
<4 \\
<4\end{array}$ & $\begin{array}{l}4 \\
3 \\
2 \\
4 \\
4\end{array}$ & $\begin{array}{r}3 \\
<1 \\
<3 \\
<4 \\
13\end{array}$ & $\begin{array}{l}<.8 \\
<.8 \\
<.6 \\
<.8\end{array}$ & $\begin{array}{r}<4 \\
<4 \\
3 \\
<4 \\
<4\end{array}$ & $\begin{array}{l}1.8 \\
.8 \\
.8\end{array}$ & $\begin{array}{r}.4 \\
.4 \\
.3 \\
.4 \\
.4\end{array}$ & $\begin{array}{l}560 \\
550 \\
560 \\
560 \\
590\end{array}$ & $\begin{array}{r}5 \\
\leqslant 5 \\
6 \\
8 \\
8\end{array}$ & $\begin{array}{r}2 \\
\times 2 \\
<3 \\
46\end{array}$ & $\begin{array}{r}4 \\
4 \\
3 \\
3 \\
6\end{array}$ & $\begin{array}{r}<60 \\
160 \\
N 0 \\
N D \\
4180\end{array}$ & $\begin{array}{l}\cdots \\
\cdots \\
\cdots \\
\cdots\end{array}$ \\
\hline $\begin{array}{r}4-29-69 \\
8-15-69 \\
10-1-69\end{array}$ & $\begin{array}{l}40 \\
34 \\
12\end{array}$ & $\begin{array}{l}25 \\
38 \\
27\end{array}$ & $\begin{array}{r}<.7 \\
<2 \\
<.8\end{array}$ & $\begin{array}{l}<2 \\
<8 \\
<4\end{array}$ & $\begin{array}{l}17 \\
37 \\
35\end{array}$ & $\begin{array}{l}<35 \\
<80 \\
<38\end{array}$ & $\begin{array}{r}5 \\
6 \\
64\end{array}$ & $\begin{array}{l}<3 \\
<8 \\
<3\end{array}$ & $\begin{array}{l}8 \\
7 \\
4\end{array}$ & $\begin{array}{l}\because \\
\mathrm{NO}\end{array}$ & $\begin{array}{l}<3 \\
<8 \\
<4\end{array}$ & $\begin{array}{l}23 \\
33 \\
15\end{array}$ & $\begin{array}{l}2 \\
<\frac{1}{4} \\
<3\end{array}$ & $\begin{array}{l}2 \\
2 \\
3\end{array}$ & $\begin{array}{r}49 \\
13 \\
6\end{array}$ & $\begin{array}{r}<.7 \\
<2 \\
<.8\end{array}$ & $\begin{array}{r}5 \\
<6 \\
4\end{array}$ & $3^{6}$ & $\begin{array}{r}<.3 \\
<.4 \\
<.4\end{array}$ & $\begin{array}{l}370 \\
630 \\
530\end{array}$ & $\begin{array}{r}4 \\
8\end{array}$ & $\begin{array}{r}4 \\
4 \\
4\end{array}$ & $\begin{array}{r}3 \\
4 \\
-3\end{array}$ & $\begin{array}{r}130 \\
2240 \\
\times 150\end{array}$ & no \\
\hline
\end{tabular}

${ }^{2}$ Essential element of aigae. 
Table 17.--Pesticide concentrations in samples from Oneida Lake or October 1, 1969

(Values represent micrograms per liter for water and micrograms per kilogram for sediment; $t r=$ trace amount detected.)

\begin{tabular}{|c|c|c|c|c|c|c|c|c|c|c|c|c|}
\hline \multirow[b]{2}{*}{ Location } & \multirow[b]{2}{*}{ Sample } & \multicolumn{11}{|c|}{ Pesticide } \\
\hline & & $\begin{array}{l}\text { Al } \\
\text { drin }\end{array}$ & DDD & DDE & DDT & $\begin{array}{l}\text { Diel- } \\
\text { drin }\end{array}$ & $\begin{array}{l}\text { En- } \\
\text { drin }\end{array}$ & $\begin{array}{l}\text { Hepta- } \\
\text { chlor }\end{array}$ & $\begin{array}{l}\text { Lin- } \\
\text { dane }\end{array}$ & $2,4 \cdots D$ & $2,4,5-T$ & $\begin{array}{l}\text { sil- } \\
\text { vex }\end{array}$ \\
\hline \multirow{2}{*}{$\begin{array}{l}\text { Oneida Lake at } \\
\text { Shackelton Point }\end{array}$} & Water & 0.00 & 0.01 & 0.00 & 0.00 & 0.00 & 0.00 & $\operatorname{tr}$ & $\operatorname{tr}$ & 0.00 & 0.00 & 0.00 \\
\hline & Sediment & .00 & .00 & .00 & .00 & .00 & .00 & .00 & .00 & -- & -- & -- \\
\hline \multirow{2}{*}{$\begin{array}{l}\text { Oneida River } \\
\text { at Brewerton }\end{array}$} & Water & .00 & .00 & .00 & .00 & .00 & .00 & $\operatorname{tr}$ & tr & .00 & .00 & .00 \\
\hline & Sediment & .00 & 2.00 & .80 & .00 & .00 & .00 & .00 & .00 & -- & -- & -- \\
\hline
\end{tabular}




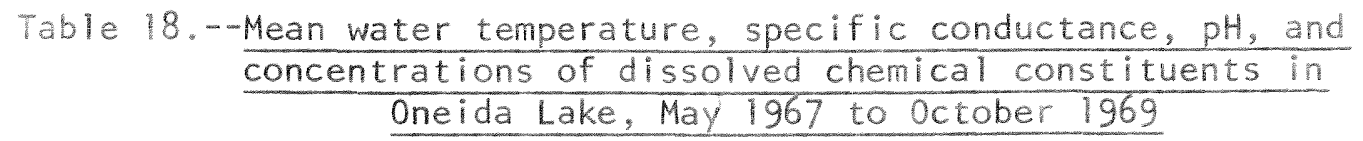

(Except for $\mathrm{pH}$, values are expressed as milligrams per liter unless otherwise indicated. $N D=$ not detected)

\begin{tabular}{|c|c|c|c|}
\hline Parameter & Value & Parameter & Value \\
\hline 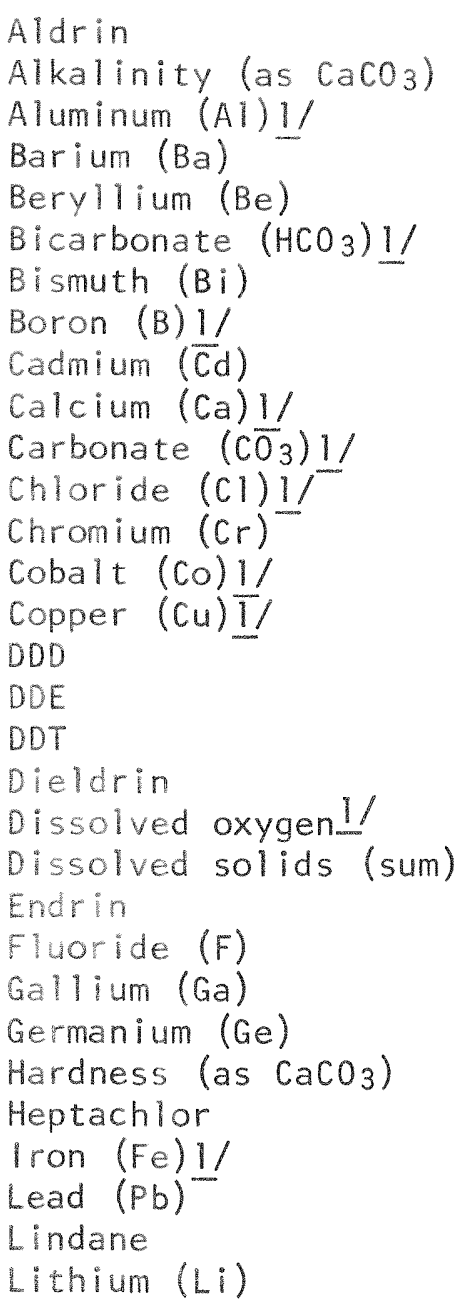 & $\begin{array}{c}81 \\
0.03 \\
0.032 \\
<.0008 \\
99 \\
<.004 \\
.024 \\
<.03 \\
38 \\
<1 . \\
9.0 \\
.007 \\
<.008 \\
.007 \\
<.00001 \\
N D \\
N D \\
\text { ND } \\
9.6921 \\
163 \\
N D \\
.1 \\
<.002 \\
<.004 \\
124 \\
\text { Trace } \\
.037 \\
<.006 \\
\text { Trace } \\
.003\end{array}$ & 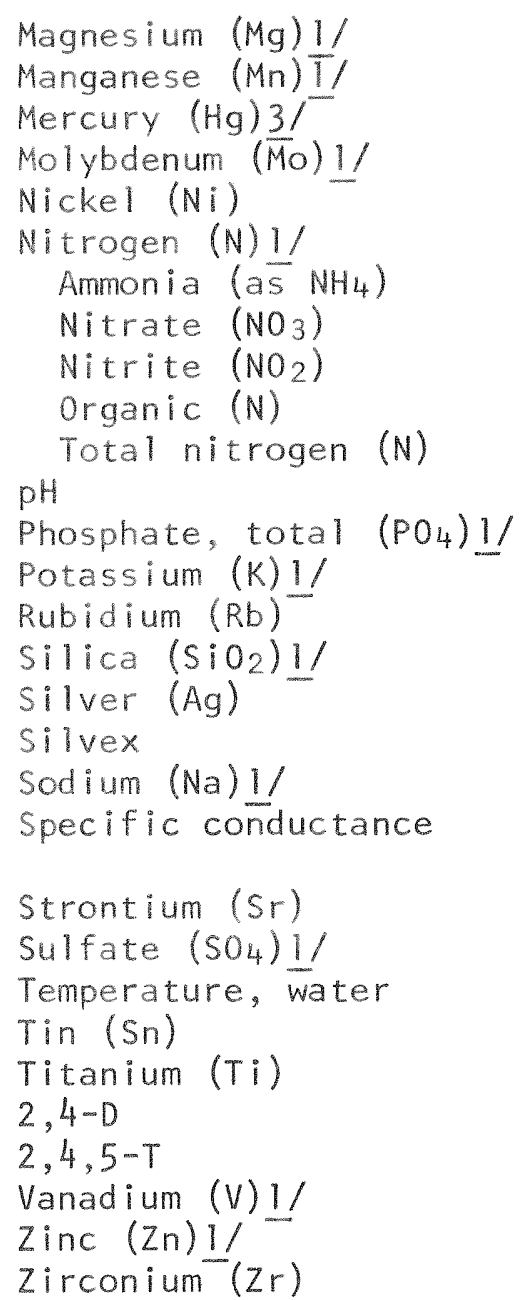 & $\begin{array}{c}.12 \\
.4 \\
.01 \\
.16 \\
.34 \\
8.1 \\
.12 \\
.9 \\
<.001 \\
2.1 \\
<.0004 \\
\quad N D \\
4.9 \\
275 \quad \mu m h o s / \mathrm{cm} \\
a t \quad 25^{\circ} \mathrm{C} \\
.47 \\
48 \\
19.1^{\circ} \mathrm{C} \\
<.008 \\
<.004 \\
\text { ND } \\
\text { ND } \\
<.004 \\
<.02 \\
\text { ND }\end{array}$ \\
\hline
\end{tabular}

$1 /$ Essential to algal growth.

2) 107 percent saturation.

3) Mercury determined during midsummer, 1970. 


\section{Chemical Contributions to Oneida Lake}

Amounts of dissolved chemical substances entering Oneida Lake were represented by the sum of dissolved materials from the tributaries, from direct precipitation on the lake surface, and from man's activities on and around the lake. Contributions from ground water were negligible.

Mean annual loads, expressed as tons per day, of the chemical constituents carried by the streams to the lake were determined mostly from data of Pearson and Meyers (in press). To estimate chemical contributions from unmeasured areas of the basin, Pearson and Meyers determined the chemical yields (load per day, in tons per square mile) of the five terranes. From yield information and with knowledge of the terrane composition of unmeasured areas, it was then possible to estimate the mean annual loads from any area of interest.

Mean annual loads of major chemical constituents entering Oneida Lake are summarized in table 19. It was impossible to quantify the loads of trace metals because of minute quantities present and lack of numerous routinely collected samples. Estimated mean annual loads, however, of the essential metals entering Oneida Lake from all sources generally ranged from 1 to 50 lbs per day. Essential metals included aluminum boron, cobalt, copper, iron, manganese, molybdenum, vanadium, and zinc. Concentrations of trace metals in the tributaries to Oneida Lake during two sampling visits in 1969 are given in table 20.

Fish Creek, including East and West Branches, which contributed about 44 percent of the water entering Oneida Lake, carried only 125 tons per day, or 10 per cent of the total inflowing dissolved solids. Other north tributaries, Scriba and Wood Creeks, also carried relatively small chemical loads.

Chittenango Creek contributed 458 tons per day, or 37 percent of the dissolved solids entering the lake. Most of the materials originated in the soluble deposits of the Salina Group Terrane (fig. 4). The stream was the major contributor of dissolved nutrient materials even though its annual discharge represented only 17.8 percent of the total water budget. The annual amount of water from Chittenango Creek was less than the amount of water from either East Branch or West Branch Fish Creeks, yet the south stream carried almost four times as much dissolved materials as the two north streams combined.

The second largest load of dissolved solids was carried by Oneida creek. The load averaged 220 tons per day, or 17.8 percent of the total. The complex of Cowaselon and Canaseraga Creeks contributed about 16.6 percent of the dissolved solids, or about 206 tons per day. Even though Cowaselon and Canaseraga Creeks represented only 6 percent of the drainage basin and carried only about 5 percent of the water, their dissolved-solids contribution to Oneida Lake was almost as great as the entire north basin.

Chittenango creek carried the largest loads of most major chemical substances, including calcium, magnesium, potassium, strontium, bicarbonate, sulfate, and total nitrogen. Ungaged areas contributed slightly larger 


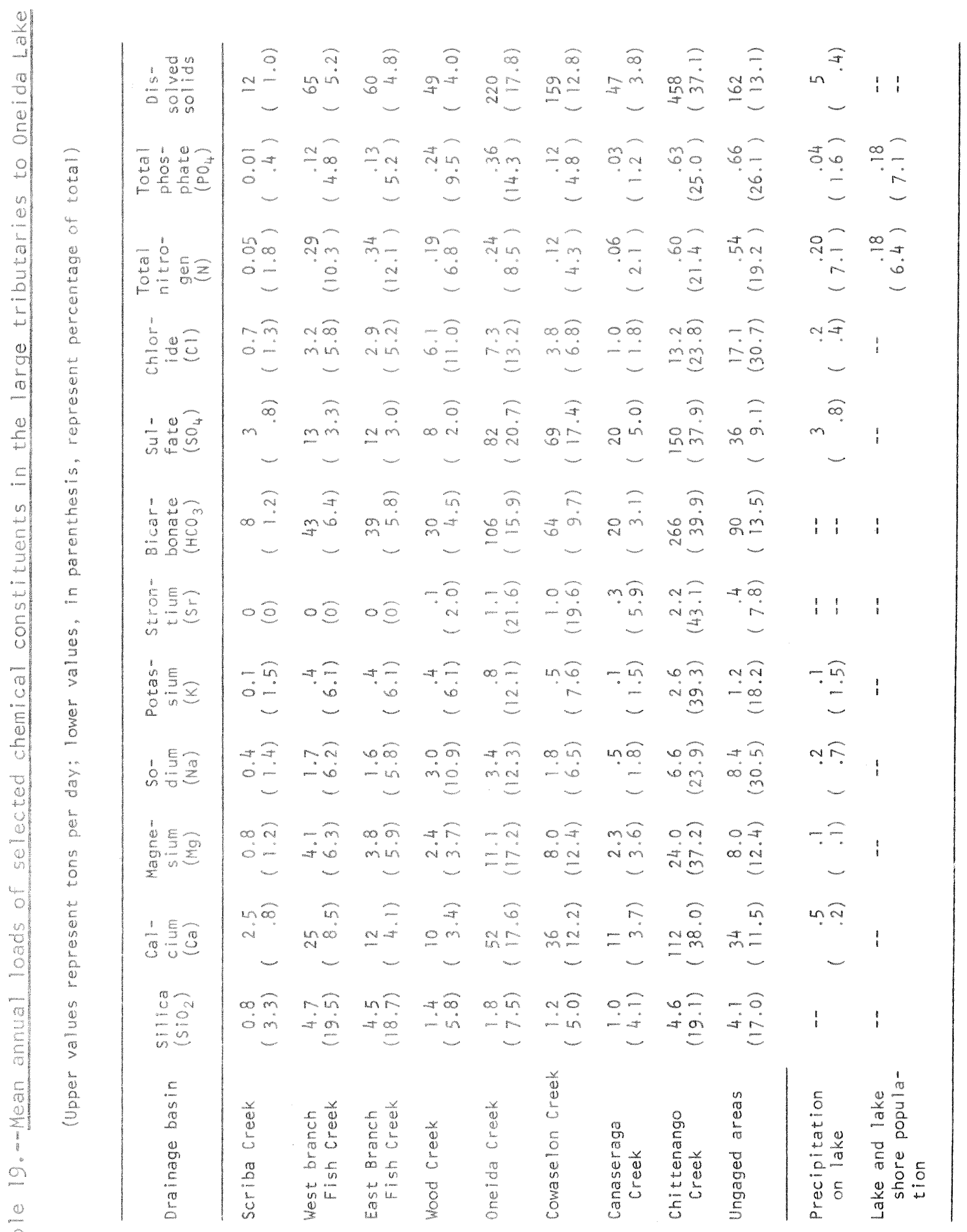




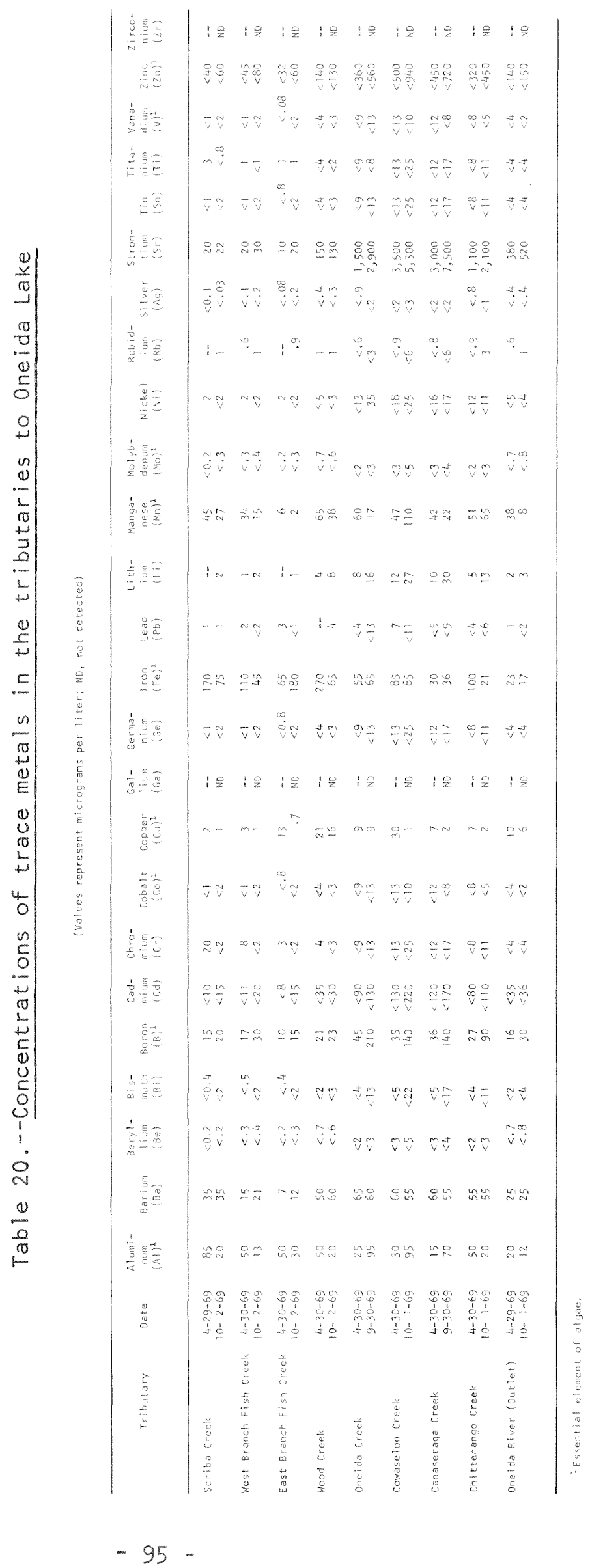


amounts of sodium, chloride, and total phosphate. The sources of larger amounts of sodium and chloride were extensive salt deposits in the Salina Group Terrane (Pearson and Meyers, in press).

Chemical loads dellvered to the surface of Oneida Lake by precipitation were determined by F. J. Pearson, Jr., from unpublished data obtained from a statewide sampling network. Precipitation carried about 0.4 percent (5 tons per day) of the dissolved sollids entering the lake.

The nitrogen load in precipitation was greater than the nitrogen loads contributed by four of the major tributary systems, including scriba, Wood, Cowaselon, and Canaseraga creeks. The 0.20 tons per day of total nitrogen in precipitation was equivalent to a concentration of $0.33 \mathrm{mg} / 1$. The average concentration of total nitrogen dissolved in Oneida Lake during the study was $0.34 \mathrm{mg} / 1$ (table 18).

The phosphate load in precipltation was greater than the phosphate loads contributed by both scriba and Canaseraga creeks. The milligram per liter equivalent of the precipitation-contributed 0.04 tons of phosphate per day was 0.06. According to sawyer (1947), this concentration is six times that necessary for supporting algal blooms.

Pearson and Meyers (in press) determined that streams draining the relatively undeveloped north parts of the bas in had combined average nitrogen yields of 0.0016 tons per day per square mile or a total load of 0.97 tons per day. They found that the streams of the south basin carried an average of 0.0020 tons per day per square mile or a total of 1.46 tons per day.

The difference between contributions of nitrogen from the north and the south parts of the basin (that is, 0.0004 tons per day per square mile) reflected a larger population served by sewers in the south. The average load of nitrogen in the south streams, exclusive of sewered domest ic wastes, therefore, could be said to be 0.0016 tons per day per square mile, or the same as the nitrogen loads in the north streams. Pearson and Meyers (in press) concluded that the basinwide nitrogen yield, exclusive of sewered wastes, approximated the yields expected from nonagricultural lands. Nitrogen contributions, therefore, from nonsewered domestic wastes and from agriculture were minimal.

According to the American Water Works Association (1967), the per capita load of nitrogen in domestic sewage ranges from 0.011 to $0.017 \times$ $10^{-3}$ tons per day. The contribution of nitrogen to Oneida Lake from lakeshore residents (about 14,000 persons) and from visiting sportsmen was probably near the lower values of the range because the population fluctuated considerably with lake usage. Assuming that the per capita contribution was $0.013 \times 10^{-3}$ tons per day, the total nitrogen contribution from lake users would have been 0.18 tons per day.

Pearson and Meyers (in press) also found that the north drainage basin contributed less phosphate to the lake than the south basin. Contributions were 0.0006 and 0.0021 tons per day per square mile, respectively. The authors attributed the load difference to differences in geology and population. The sewered waste of population in the south basin accounted for 
0.0006 tons per day per square mile (0.32 tons per day), a quantity equal to the amount of total phosphate contributed by the entire north basin.

The greatest source of phosphate in the Oneida Lake basin is the Lake Plain. Pearson and Meyers (in press) estimated that the natural contribution of phosphate from the Lake Plain was 0.034 tons per day per square mile. Phosphate originated in the peaty sediments of ancestral oneida Lake and in extensive swamp and marsh areas.

The large natural contribution of phosphate from the Lake Plain accounted for the relatively large phosphate load in Wood Creek. It was 0.24 tons per day (table 19), the third largest load in all sampled streams.

Users and lake-shore residents of Oneida Lake contributed $0.013 \times 10^{-3}$ tons of phosphate per capita per day, on the basis of values published by the American Water Works Association (1967). The total amount of phosphate from lake usage, therefore, was 0.18 tons per day.

Cultural contributions of total nitrogen and total phosphate to oneida Lake were determined to be at maximum 0.48 and 0.50 tons per day, respectively (table 21). These values represented about 17 percent of the nitrogen and 20 percent of the phosphate entering Oneida Lake.

If the cultural sources of the two nutrients were eliminated, loads of nitrogen and phosphate entering the lake from natural sources would be sufficient to maintain concentrations above the minimums necessary to support large algal blooms in Oneida Lake. Even though nitrogen and phosphorus are not limiting factors on algal growth in the lake, they are key nutrients that contribute to increased enrichment. An elimination of the cultural influences would, in theory, decrease the rate of eutrophication by as much as 20 percent.

Table 21.--Cultural contributions of nitrogen and phosphate to Oneida Lakel

\begin{tabular}{|c|c|c|}
\hline $\begin{array}{l}\text { Cultural } \\
\text { source }\end{array}$ & Tons per day & $\begin{array}{l}\text { Percent of total } \\
\text { inflowing load }\end{array}$ \\
\hline \multicolumn{3}{|l|}{ NITROGEN } \\
\hline Basin & 0.30 & 10.7 \\
\hline Lake shore & 0.18 & 6.4 \\
\hline Total & $\overline{0.48}$ & 17.1 \\
\hline \multicolumn{3}{|l|}{ PHOSPHATE } \\
\hline Basin & 0.32 & 12.7 \\
\hline Lake shore & 0.18 & 7.1 \\
\hline Total & $\overline{0.50}$ & 19.8 \\
\hline
\end{tabular}

1 Based on Pearson and Meyers (in press). 
Nutrient Budgets of Oneida Lake

Nutrient budgets of Oneida Lake were established by determining the quantities of nutrient materials entering the lake and the quantities of nutrient materials leaving the lake through its outlet, the Oneida River. Differences between the values were the result of chemical and biological processes in the lake.

Table 22 presents chemical budgets of the major nutrients in Oneida Lake for 1967 through 1969. The north drainage basin, which consists of 43 percent of the total basin and supplied 67 percent of the water, contributed only 17.4 percent or 215 tons per day of the dissolved solids that entered Oneida Lake. The naturally fertile south basin, which forms 51 percent of the total basin and supplied one-third of the water, supplied 82 percent, or 1,017 tons per day, of the dissolved solids. Contributions of dissolved solids from precipitaton and from man's activities on and around the lake was 5 tons per day $(0.4$ percent), negligible compared with the stream loads.

Daily inflow of dissolved solids to Oneida Lake was 1,237 tons or about 450,000 tons per year ( $\mathrm{fig} .44$ ). These nutrients supported the algal blooms. About 89 percent, or 1,100 tons per day, of the nutrients that entered the lake was discharged from the lake by the Oneida River. About 11 percent, or 137 tons per day, of the nutrients was retained by the lake.

OUTFLOW

INFLOW

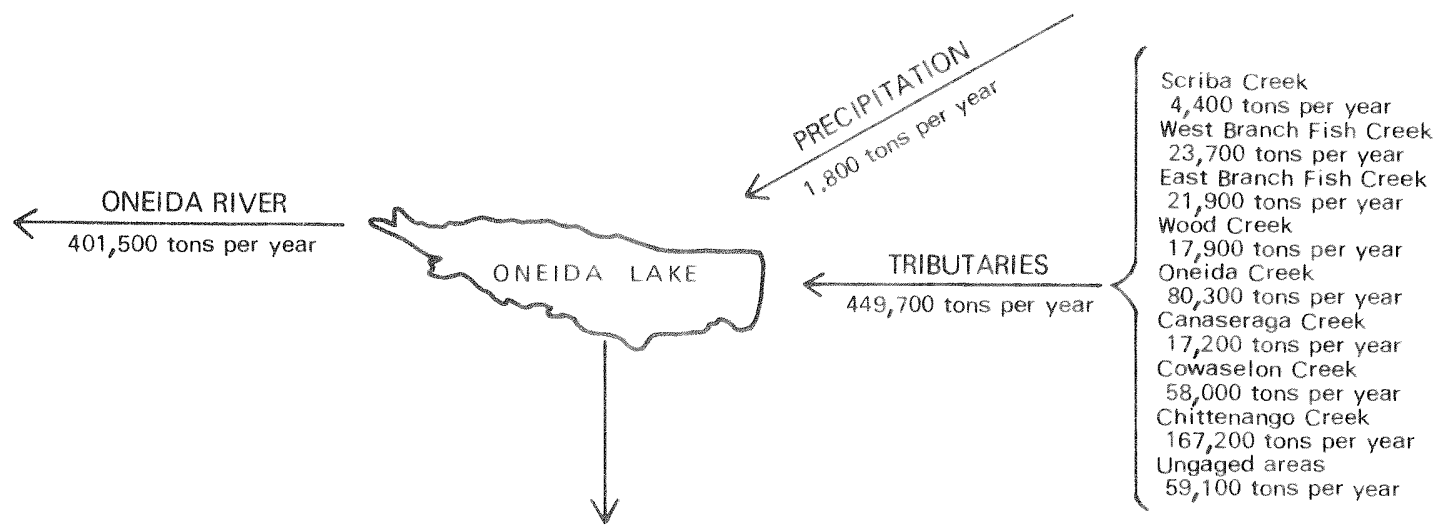

LAKE RETENTION

50,000 tons per year

Figure 44.--Chemical budget of dissolved solids in Oneida Lake. 
Table 22. - - Chemical budgets of the major nutrients in oneida Lake

(Upper values represent tons per day; lower values, in parenthesis, represent percentage of total)

\begin{tabular}{|c|c|c|c|c|c|c|c|c|c|c|c|c|}
\hline $\begin{array}{l}\text { Inflows } \\
\text { and } \\
\text { outflow }\end{array}$ & $\begin{array}{l}\text { Silica } \\
\left(\mathrm{SiO}_{2}\right)\end{array}$ & $\begin{array}{l}\mathrm{Cal-} \\
\text { cium } \\
\text { (Ca) }\end{array}$ & $\begin{array}{c}\text { Magne- } \\
\text { sium } \\
\text { (Mg) }\end{array}$ & $\begin{array}{l}\text { So- } \\
\text { dium } \\
\text { (Na) }\end{array}$ & $\begin{array}{l}\text { Potas - } \\
\text { sium } \\
\text { (k) }\end{array}$ & $\begin{array}{l}\text { Stron } \\
\text { tium } \\
(\mathrm{Sr})\end{array}$ & $\begin{array}{l}\text { Bicar- } \\
\text { bonate } \\
\left(\mathrm{HCO}_{3}\right)\end{array}$ & $\begin{array}{l}\text { Sul- } \\
\text { fate } \\
\left(\mathrm{SO}_{4}\right)\end{array}$ & $\begin{array}{l}\text { Chlor- } \\
\text { ide } \\
\text { (cl) }\end{array}$ & $\begin{array}{l}\text { Total } \\
\text { nitro- } \\
\text { gen } \\
(N)\end{array}$ & $\begin{array}{l}\text { Total } \\
\text { phos- } \\
\text { phate } \\
\left(\mathrm{PO}_{4}\right)\end{array}$ & $\begin{array}{l}\text { Dis- } \\
\text { solved } \\
\text { solids }\end{array}$ \\
\hline $\begin{array}{c}\text { Northern drain- } \\
\text { age basin }\end{array}$ & $\begin{array}{l}12.1 \\
(50.2)\end{array}$ & $\left(\begin{array}{l}55.5 \\
18.8)\end{array}\right.$ & $\begin{array}{l}13.5 \\
(19.3)\end{array}$ & $\begin{array}{c}8.2 \\
(29.7)\end{array}$ & $\begin{array}{c}1.5 \\
(22.7)\end{array}$ & $\begin{array}{l}0.2 \\
3.9)\end{array}$ & $\begin{array}{l}136 \\
(20.4)\end{array}$ & $\begin{array}{l}43 \\
(10.9)\end{array}$ & $\begin{array}{l}16.0 \\
(28.8)\end{array}$ & $\begin{array}{c}0.97 \\
(34.5)\end{array}$ & $\begin{array}{c}0.62 \\
(24.6)\end{array}$ & $\begin{array}{l}215 \\
17.4)\end{array}$ \\
\hline $\begin{array}{c}\text { Southern drain- } \\
\text { age basin }\end{array}$ & $\begin{array}{c}12.0 \\
(49.8)\end{array}$ & $\begin{array}{r}239 \\
(81.0)\end{array}$ & $\begin{array}{l}52.0 \\
(80.5)\end{array}$ & $\begin{array}{l}19.2 \\
(69.6)\end{array}$ & $\begin{array}{c}5.0 \\
(75.8)\end{array}$ & $\begin{array}{c}4.9 \\
(96.1)\end{array}$ & $\begin{array}{l}530 \\
(79.6)\end{array}$ & $\begin{array}{l}350 \\
(88.3)\end{array}$ & $\begin{array}{l}39.3 \\
(70.8)\end{array}$ & $\begin{array}{c}1.46 \\
(52.0)\end{array}$ & $\begin{array}{c}1.68 \\
(66.7)\end{array}$ & $\begin{array}{r}1,017 \\
82.2)\end{array}$ \\
\hline Other sources 1 & -- & $\left(\begin{array}{l}.5 \\
(.2)\end{array}\right.$ & $\left(\begin{array}{l}.1 \\
.2)\end{array}\right.$ & $\left(\begin{array}{l}.2 \\
.7)\end{array}\right.$ & $(1.5)$ & -- & $-\infty$ & $\left(3^{3} .8\right)$ & $\begin{array}{l}.2 \\
.4)\end{array}$ & $(13.5)$ & $(8.7)$ & 5 \\
\hline $\begin{array}{l}\text { Total inflow } \\
\text { to lake }\end{array}$ & 24.1 & 295 & 65.6 & 27.6 & 6.6 & 5.1 & 666 & 396 & 55.5 & 2.81 & 2.52 & 1,237 \\
\hline $\begin{array}{l}\text { Total outflow } \\
\text { from lake }\end{array}$ & 24.0 & 260 & 58.0 & 27.0 & 6.5 & 3.7 & 660 & 330 & 59.0 & 2.26 & .96 & 1,100 \\
\hline $\begin{array}{l}\text { Retention by } \\
\text { lake }\end{array}$ & $\left(\begin{array}{l}.1 \\
.4\end{array}\right)$ & $\begin{array}{l}35 \\
(11.9)\end{array}$ & $\begin{array}{c}7.6 \\
(10.2)\end{array}$ & $\begin{array}{c}.6 \\
(2.2)\end{array}$ & $(1.5)$ & $\begin{array}{c}1.4 \\
(27.4)\end{array}$ & $\left(\begin{array}{l}6 \\
.9\end{array}\right)$ & $\begin{array}{l}66 \\
(16.7)\end{array}$ & -3.5 & $(19.6)$ & $\begin{array}{c}1.56 \\
(61.9)\end{array}$ & $\left(\begin{array}{l}137 \\
11.1)\end{array}\right.$ \\
\hline
\end{tabular}

1 Precipitation and lake and lake-shore population. 
Percentage retention of calcium and magnesium by Oneida Lake approximated percentage retention of dissolved solids. Values were 11.9 percent and 10.2 percent for calcium and magnesium, respectively. Pearson and Meyers (in press) found that Oneida Lake was oversaturated with calcium carbonate; therefore, lake retention of calcium and magnesium ions was probably by chemical precipitation.

Relatively small quantities of sodium, potassium, silicon dioxide, and bicarbonate were retained. Percentage retentions of each was insignificantly less than has been reported for other north lakes (Miller and Tash, 1967).

of the 396 tons of sulfate per day that flowed into Oneida Lake, 330 tons per day, or 83.3 percent, left by way of the Oneida River. The fate of retained sulfate was difficult to determine because sulfate concentration was less than saturation in the lake water and because a similar calcium concentration precluded precipitation of minerals such as gypsum $\left(\mathrm{CaSO}_{4} \cdot 2 \mathrm{H}_{4} \mathrm{O}\right)$ (Pearson and Meyers, in press). A considerable quantity of sulfate, however, is converted into the protoplasm of blue-green algae. on death and decay of wind-blown algae on the lake shore, obnoxious hydrogen sulfide (from reduced sulfate) is released to the atmosphere. Every user of Oneida Lake has observed such offensive decaying masses. This release of sulfide partly accounted for loss in the sulfate budget; however, it could not be quantified.

Computations indicated that 59.0 tons of chloride per day was leaving the lake through the Oneida River whereas only 55.5 tons per day was entering the lake from all sources. The difference of 3.5 tons per day probably reflected error in sampling and analysis.

Total nitrogen input to Oneida Lake was estimated to be 2.8 tons per day, of which 2.3 tons per day left the lake. Table 22 shows that the lake retained 0.55 tons per day, or 19.6 percent of the total nitrogen it received. Nitrogen retention was less than that found by Sawyer (1947) in three Wisconsin lakes. He reported that nitrogen retention in the lakes ranged from 30.4 percent to 60.5 percent but that the lakes had been enriched with domestic wastes.

Oneida Lake retained 61.9 percent ( 1.56 tons per day) of inflowing dissolved phosphate (table 22). Phosphate retention was about 20 percent higher than had been reported in Lake Sebasticook, Maine (Mackenthun, and others, 1968, and Federal Water Pollution Control Administration, 1966), and in Upper Klamath Lake, Oregon (Miller and Tash, 1967). Retention of phosphate by Oneida Lake occurred as accumulations in the bottom sediments of organic debris and of inorganic precipitates, such as apatite (Pearson and Meyers, in press).

Retained nutrients will remain in solution, become incorporated in living organisms, or become part of the bottom sediments. Recycling of nutrients occurs among the three. Because previous discussion (see section, "Long-term chemical variations,") has shown that no definable increase in the gross chemical composition of Oneida Lake has occurred during the period of record, most of the materials retained by the lake have probably become a permanent part of the bottom sediments. 
Only a small amount of nutrients have contributed and are contributing to the increased enrichment (that is, eutrophication) of the lake water. Therefore, the rate of eutrophication of Oneida Lake can be considered to be slow, and the eutrophic state of the lake can be considered to have remained virtually unchanged for many years. In Oneida Lake, natural eutrophication has been a very slow process. 



\section{BIOLOGICAL CHARACTERISTICS OF ONEIDA LAKE}

\section{Flora and Fauna}

From the days of Samuel D. Champlain, who described the fish as being very plentiful (Biggar, 1929), the production capabilities of Oneida Lake have been well known. In 1792, Francis Adrian Vanderkemp described enormous mayfly hatches. He wrote, "The lake was covered with hundreds, thousands, millions of insects which in Holland we call haft, and which lay on some parts of the shore one and two inches deep" (after Landgraff, 1911).

James Fenimore Cooper, in 1809, in addition to describing the algae (see section, "The Problem"), stated that the boatmen on the lake asserted that more than a hundred salmon could be caught in 1 day (after Landgraff, 1911). Mozley (1954) cited Oneida Lake as "one of the most productive lakes 1 have seen on any continent."

The first scientific observation of Oneida Lake (in 1886) was described in the annual report of the New York State Board of Health (1888). The report discussed the physical setting of the lake, currents, water chemistry, and planktonic organisms. Of the latter, the report stated, "microscopic plants and infusorial animals, somewhat numerous." Algal blooms were described as thick, yellowish-green scum through which the "track of a boat could be seen for many rods in its wake." The report concluded that Oneida Lake existed under conditions especially favorable to maintenance of a prolific growth of organisms during summer months.

Because of prolific growths and diversities of aquatic organisms and because of the proximity of the lake to academic institutions, Oneida Lake was the site of several classical studies during the early 1900's. The first two by Baker $(1916 \mathrm{c}, 1918)$ considered invertebrate benthos and emphasized molluscan fauna. Baker (1916b) said that except for the fresh-water molluscs in Saginaw Bay in Lake Huron, the fresh-water molluscs in Oneida Lake were greater in number of species than that of any similar body of water in the United States. He found 62 species.

Baker (1918) observed that conditions necessary for abundant growth of algae in the lake were "admirably met" and, as a result, the algal flora was abundant in both species and individuals. Baker (1916c) reported a bloom of Rivularia in september 1916.

Another classical study from 1914 through 1927 (Adams and Hankinson, 1928f) considered the fish fauna. The major objective of these investigators was to develop a fish-management system for the lake. The result of their work was a lengthy description of 59 species of fish, including life histories, habits, ecology, and economics. The authors, in addition, reported "water blooms" on Oneida Lake and specifically described a bloom of Gloeotrichia echinulata on August 30, 1918.

Gloeotmichia echinulata is a bloom-forming, blue-green alga that is visible to the unaided eye. It appears as a small dark-brown, burrlike ball (fig. 45C). This alga is the only alga having such an appearance. UndoubtedIy, the alga described in 1809 by James Fenimore Cooper as a "dark particle ...called lake blossoms" was Gloeotrichia echinulata. 
Phytoplankton population in Oneida Lake in August and September 1927 consisted primarily of diatoms (Muenscher, 1928). Asterionezla was the most common. Blue-green algae, however, were "well represented" by Anabaena and Microcystis. Because of reported blue-green algal blooms before and after the visit by Muenscher, the summer of 1927 was probably atypical of normal conditions in the lake. This assumption is strengthened by an examination of hydrologic records for 1927 (U.S. Geological Survey, 1958), which reveals that the flow of water from the north drainage basin was about 25 percent more than the long-term average. Such a large flow of water from the north probably resulted in a decrease of available nutrients in the lake (see section, "Temporal Differences") and accompanying reduction of algal production. (See section, "Ecological Implications.")

Muenscher (1928) found the seston (see Glossary) to average $4.56 \mathrm{mg} / 1$. During the current study, seston averaged $13.2 \mathrm{mg} / 1$ and ranged from 0 to $41.4 \mathrm{mg} / 1$.

Changes in the biota of Oneida Lake were described by Dence and Jackson (1959), Harman and Forney (1970), Jacobsen (1966), and Noble (1968, 1969).

Dence and Jackson (1959) discussed changes in fish fauna. The most remarkable change was the complete absence of the Atlantic salmon (Satmo satar), which was extremely abundant when champlain visited the area in the early 1600's. Tullibee or cisco, sea lamprey, and American eels have become scarce. Increases in the numbers of gizzard shad, white perch, and sheepshead or fresh-water drum have become obvious to the benefit of walleye (Stizostedion vitreum) and yellow perch (Perca flavescens).

Production of walleye and yellow perch makes Oneida Lake "the fishiest lake of them all" (Karas, 1967). J. L. Forney (written commun., 1969) stated that the fishes populations were fairly stable and that oneida Lake contains up to $1,400,000$ pounds of age 111 or older walleyes. Recent studies of the dynamics of Onelda Lake fish populations include forney (1961a and $b ; 1963 ; 1964 a, b$, and $c ; 1965 a, b$, and $c ; 1966 a, b, c$, and d); Forney and Houde (1964 and 1965); and Forney and Taylor (1963).

The most thorough examination of biological changes in oneida Lake was undertaken by Noble (1969), who emphasized aquatic vascular plants and benthic fauna. His area of study was Lower South Bay, the same area studied by Baker (1916c, 1918). Noble found that by 1967 there had been a general increase in sponges, tubificids, and amphipods and a decrease in numbers of isopods, mayflies, and caddisflies. Bithynia tentaculata, a gastropod that Baker found to be relatively uncommon, was the principle mollusc in Noble's collections. It dominated all studied habitats.

Harman and Forney (1970) concurred with Noble about the dominance of Bithynia and found an accompanying decrease in the pleurocerid snails, Pleurocera and Goniobasis. The authors concluded that continuing eutrophication of Oneida Lake was responsible for the reduction in the molluscan species diversity. They predicted that a small number of species, occuring in vast numbers, would eventually dominate the molluscan fauna of Oneida Lake. 
Jacobsen (1966) was the first investigator to observe a change in the structure of the benthic community in oneida Lake. He found a decrease in abundance of the burrowing mayfly. Hexagenia limbata a tremendously abundant insect during the studies of Baker $(1916 \mathrm{c}, 1918)$ and Adams and Hankinson (1928b). Jacobsen found that the mayfly had been replaced by chironomids, and he accredited the succession to oxygen depletion in the deeper water of the lake in summer. He was the first to report the oxygen depletions that are characteristic of Oneida Lake.

Noble (1969) found that the dominant species of vascular plants, particularly the submergent forms, had changed from several species of Potomogeton to Heteranthera dubia and CeratophyzLum demersum. He found Chara, stated by him to be previously uncommon (see section, "Geology"), to be common in 1967. Emergent and floating plants were virtually unchanged.

Zooplankton of Oneida Lake was first examined by Muenscher (1928), who found Daphnia to be the most common genus. Diaptomus and Cyclops were also quite common. According to Hall (1967) and Houde (1968), zooplanktonic populations are dominated by the crustaceans, Daphira galeata mendotae, Epischura lacustris, Diaptomus mimutis, and Cyclops bicuspidatus thomasi.

Neither recent studies nor the present study has undertaken comprehensive survey of flora and fauna characteristic of Oneida Lake. Only a few major groups of organisms have been studied, and any significance of changes in organismal dominance or species diversity can only be speculated. The changes, yet to be fully defined, seem to be another step in the neverceasing natural process of lake succession, or eutrophication.

Table 32 in the Appendix is a partial checklist of organisms collected, observed or identified, and probably still present in Oneida Lake. Names are in current taxonomic terminology. The compilation was obtained from data collected in the current study (especially for algae and vascular plants) and from information available in the following publications: Adams (1928a and 1928b); Adams and Hankinson (1916, 1928a, and 1928b); Baker (1916a, 1916b, 1916c, and 1918); Dence and Jackson (1959); Flory (1956); Hall (1967); Hankinson (1928a and 1928b): Harman and Forney (1970); Houde (1968); House (1918); Noble (1968 and 1969); Pilsbry (1917); Pratt (1923); Raney and Lachner (1942); and Transeau (1917).

\section{Phytoplankton}

\section{Methods of Routine Investigations}

Routine field investigations of phytoplankton of Oneida Lake were started in May 1967 and continued through April 1969. Weekly samples for quantitative and qualitative analyses were obtained from the surface and from 10-foot (3.05-meter) depth intervals at each of the 15 sampling stations in the growing seasons of 1967 and 1968. Biweekly samples were collected in fall, winter, and spring. Occasional grab samples were obtained during the summer of 1969. A total of about 900 phytoplankton samples were collected and examined. 
Phytoplankton samples were treated on collection with 40 -percent formaldehyde solution for preservation, with a concentrated solution of cupric sulfate for maintaining color of cells, and with a 20-percent detergent solution for prevention of coagulation of settled material. The resultant solution had a 3 to 4 percent concentration of formaldehyde. Occasional unpreserved samples were returned to the laboratory for examination. Unconcentrated plankton samples were used for quantitative evaluations. Net (no. 20 standard silk bolting cloth) samples and concentrates of whole samples were used for identifications.

A Sedgwick-Rafter counting cell and a whipple ocular micrometer were used for counting at $100 \mathrm{X}$ magnification. A $21 \mathrm{X}$ objective and a stereozoom lens were used for scanning fields and for greater magnification. The counting cell was filled three times with each sample, each filling was counted, and results were averaged. Twenty to 100 fields were normally counted, depending on the number of algal cells present. When concentrations were too thick for proper counting, samples were diluted with distilled water and counts were repeated. Final counts were expressed in number of cells per milliliter of sample. No attempts were made to enumerate the number of cells in colonies of Microcystis aemginosa, Microcystis incerta, Gloeotrichia echinulata, Entophysalis lemaniae, or Volvos aureus.

Temporary wet mounts of sample concentrates were used for identifications. Diatoms (Bacillariophyceae) were cleared by the method of Prescott (1962), and permanent mounts were made with heated Caedax. Species were identified when possible.

\section{Observations of the Phytoplankton}

One hundred and seventeen species of algae were observed in the phytoplankton of Oneida Lake in the study (table 23). Of these species, 42 were common or abundant; and their types and distribution followed the general pattern for a eutrophic lake (Greeson and Meyers, 1969). Table 24 indicates other forms of algae that have been recently observed in the phytoplankton of the lake but that have not been observed during this study. Representative phytoplankton are pictured in figures 45 and 46.

Figure 47, which shows relative abundances of the major groups of algae composing the phytoplankton of Oneida Lake, indicates that green algae (Chlorophyta) were dominant during late spring and early summer. These were replaced by the blue-green algae (Cyanophyta) in the summer, when light and temperature conditions were favorable. In general, bluegreen algae exhibited blooms with the start of their dominance; decreased in numbers to a more or less constant level; and, in the late summers or early falls, manifested a second major bloom before the approach of lower water temperatures. Secondary algal blooms occurred sporadically in the growing seasons (June through September). Diatoms (Bacillariophyceae) became dominant with the decline of the blue-green algae and remained dominant through winters. Species of algae observed two or more times are given in table 25. 
Blue-green algae interfere with recreation more than other algae because blooms occur when recreation is maximal. They became dominant in Oneida Lake by June 20, 1967, and June 14, 1968, when Anabaena flos-aquae comprised 91.4 percent and 76.3 percent of the standing crops, respectively (table 26). Aphanizomenon holsaticum was the dominant blue-green alga at the beginning of the growing season of 1969, when it formed 80.8 percent of the population. On October 9, 1967, and September 24, 1968, blue-green algae still dominated the phytoplankton populations and constituted 54.9 percent and 88.7 percent of the collections, respectively.

In the initial bloom of 1967, phytoplankton consisted almost entirely of blue-green algae. Average concentratic … Juy 10 was about 71,000 cells/ml (cells per milliliter). A maximu concentration of 201,900 cells/ $\mathrm{ml}$ was observed at station 12. The most abundant alga was Anabaena flosaquae.

No algal blooms occurred during the growing season of 1968. But the blue-green algae became dominant, and their population reached an average concentration of $7,650 \mathrm{ce} / 1 \mathrm{~s} / \mathrm{m}$ ) July 24. Maximum concentration on that date was $12,300 \mathrm{cel} / \mathrm{s} / \mathrm{ml}$. Aphanizonenon holsaticum attained a large population in late November 1968. Average concentration on November 26 was $10,850 \mathrm{cell} / \mathrm{s} / \mathrm{ml}$, which was 99.6 percent of the total population. A maximum concentration of 24,550 cells/ml was observed at station 12 . Average surface-water temperature in the lake on that date was $4.4^{\circ} \mathrm{C}$.

Oneida Lake experienced an enormous blue-green algal population during the entire growing season of 1969. According to local residents, the extent of the summer-long bloom was the most severe that has been witnessed in the lake. Unfortunately, routine sampling for this study had terminated in the spring of 1969; but a few random samples taken in the summer indicated that the population consisted primarlly of Microcystis aemiginosa. Aphanizomenon holsaticum was also very abundant.

During the study, the four most common species of blue-green algae in oneida Lake were Anabaena flos-aquae, Aphanizomenon holsaticum, Microcystis aemiginosa, and Anabaena circinalis. Anabaena flos-aquae and Aphanizomenon holsaticum dominated 89 percent of the blue-green algal populations. 0ther abundant blue-green algae included Ancbaena spiroides, Gloeotrichia echinulata, Microcystis incerta, Iyngbya Bixger, and oscilzatoria subbrevis.

Diatoms were the second most abundant type of algae in Oneida Lake and dominated the algal populations in Fall, winter, and spring. Although the number of diatoms decreased during the summers, they were present during the entire study.

In the growing season of 1968, when the blue-green algae failed to attain bloom concentrations, diatoms were abundant. On July 10, 1968 , Melosira spp. dominated the phytoplankton population with 56.8 percent of the standing crop. Representative species of diatoms in Oneida Lake were Melosira granulata, Asterionelia formosa, Fragilaria brevistriata, and Eragitaria crotonensis. Other common diatoms included Melosira ambigua, Metosira varians, Fragilaria capucina, Tabellaria fenestrata and Stephanodiscus niagarae. 
Commonly occurring green algae included Pediastmun duplex, Pandonina momm, Sphaerocystis Schroetem, Mirospora Witzeana, and Staurastmu paradoxum. Ceratium himudinezza, a dinoflagellate of pyrophyta, was common in spring, summer, and fall.

Phytoplankton populations were seldom uniform over the entire lake. Heavy concentrations in bay areas and localized blooms were common. Figure 48 shows spatial variations of phytoplankton in the growing seasons of 1967 and 1968. In general, concentrations of phytoplankton were heavier in the west end of the lake and along the south shore than in other areas of the lake. This resulted from higher concentrations of nutrienis in those areas and protection from prevailing winds.

In the summer of 1967 , Big Bay (station 22) was the site of the first occurrence of blue-green algae. On June 20,6 of the 16 species were of that type. An increase in concentrations of cells in the bay preceded two nejor blooms and most of the population pulses during 1967. Even though no algal blooms were developed in the lake in 1968, concentrations of bluegreen algae were generally higher in Big Bay than in other areas of the lake.

Nutrient-rich water from Big Bay Swamp flows directly into Big Bay. The nutrients in that water, supplemented by other nutritional materials from vast amounts of decaying vascular plants in the area, increase the sultabllity of Big Bay for algal growth. Calm water also aids developing populations. Because the water of the bay is shallow, solar insolation is enhanced; and warming of the water during late spring is at a comparatively higher rate.

Factors that favorably contributed to growth of blue-green aigae in Big Bay were also typical of other bay areas of the lake. In particular, Muskrat Bay, Billington Bay, Delmarter Bay, and South Bay exhibited similar characteristics.

Large concentrations of blue-green algae were often observed in the open lake east of stations 12 and 15. On August 22, 1967, plankton samples were collected at each navigation buoy from 107-FIW to 123-FIW. The buoys are about I mile apart. Shackelton Shoals are both east and west of buoy 123 (station 15), and Messenger Shoals are at buoy 113. Results from the samples are plotted in figure 49.

Concentration of phytoplankton at buoy 123 was 24,200 cells/ml (not plotted). Progressing west to east, the direction of the prevailing winds, concentration increased to a peak of 41,000 celis/ml at buoy 121 (downwind from Shackelton Shoals) and then decreased to $31,900 \mathrm{ce} i 1 \mathrm{~s} / \mathrm{ml}$ at buoy 115 . Concentration increased to $52,600 \mathrm{cell} / \mathrm{s} / \mathrm{ml}$ at Messenger Shoals (buoy 113) and again decreased eastward. At buoy 107 (station 9), the concentration of 47,500 cell $1 \mathrm{~s} / \mathrm{ml}$ resulted from accumulated algae near the shore. The algal population was dominated by Aphanizomenon holsaticum. Large numbers of Anabaena flos-aquae and Anabaena circinalis were also present. Similar spatial variations of phytoplankton were observed on several occasions. 
In perspective, algal growth was apparently stimulated near shoal areas. Chemical oxidation of sedimented organic materials occurred at a high rate in the highly oxygenated shallow water, and the recycled nutrients were transported with the slowly moving water masses. Therefore, other conditions being equal, a linear profile of algal concentrations would Illustrate a gradient from the highest concentration in the areas of high nutritional content to a proportionally lower concentration as distance from nutrient source increased.

Certain bays and shoal areas were generally the sites of accelerated phytoplankton production in Oneida Lake. Several incidents of apparent localized algal blooms (for example, along the shore or in boat harbors) were observed, and heavy concentrations of algae frequently stimulated complaints from local residents. Large algal concentrations (fig. 50), as well as decaying heaps of algae on lake-front property and beaches, resulted from wind-swept drifts of algal nats from the open lake. Decomposing algal masses produced obnoxious odors and destroyed, at least esthetically, recreational benefits of affected areas.

Many blue-green algae are vacuolized (contain air-filled pockets) and, therefore, are buoyant. When calm or near calm conditions existed on Oneida Lake in the growing seasons, the severity of algal blooms seemed to worsen because the algae floated to the surface. Crusts of algae on the surface were formed during dead-calm periods. Wind subsequently blew part of the algae toward the shore and formed localized heavy concentrations.

During prolonged windy periods, algal blooms were of no consequence in Oneida Lake because algae were mixed with the water and were distributed through the water column. Reports of algal blooms usually followed cessation of wind. The apparent severity of established algal blooms in favorable growing periods, therefore, was inversely proportional to wind action.

Most colonial (multicellular) forms of blue-green algae are enveloped in a transparent gelatinous sheath or mucllage that is similar to the albumen of an egg. (See fig. 45E.) When an algal colony begins to decompose and (or) under highly turbulent conditions, the mucilage mixes with the water to form a foamy substance that resembles soapsuds. This foamy substance can occur as wind streaks or can be blown across the water surface to accumulate near the shore. Such occurrences in Oneida Lake were very common. 


$$
\begin{gathered}
\text { Table 23.-Composite list of algae observed in phytoplankton } \\
\frac{\text { of Oneida Lake }}{(A=\text { abundant, } C=\text { common, } R=\text { rare })}
\end{gathered}
$$

CHLOROPHYTA

Actinastmum gracizizmum Smith (R)

Actinastrum Hantaschii Lagerhe im (C)

Ankistrodesmum falcatus (Corda) Ralfs (R)

Carteria KLebsiz (Dangeard) Dill (R)

Characium sp. (R)

ChIamydomonas sp. (C)

chtoretza sp. (R)

ChLorogonium elongatum (Dangeard) Franzé (R)

Cladophora glomerata (Linnaeus) Kützing (C)

Cladophora sp. (R)

Closterium Archerianum Cleve ( $R$ )

Closterium Leibleinii Kützing (R)

Closterium monizifernum (Bory) Ehrenberg (R)

Closterium strigosum DeBrébisson (R)

Coetastrum microporum Nägeli (R)

Coronastmm aestivale Thompson $(R)$

Cosmarium Boekiz Wille (R)

Cosmarium sp. (R)

Crucigenia rectangularis (Braun) Gay $(R)$

Dictyosphaerium pulche Zlum Wood (C)

Elakatothrix vixidis (Snow) Printz (R)

Emrerella bornhemiensis Conrad $(R)$

Eudorina eZegans Ehrenberg (c)

Gloeocystis gigas (Kützing) Lagerheim (R)

Golenkinia radiata (Chodat) Wille (R)

Hydrodictyon retioulatum (Linnaeus) Lagerheim (R)

Kirchnerielza Zunaris (Kirchner) Möbius (R)

Micractinium pusizlum Fresenius (R)

Microspora Loefgrenii (Nordstedt) Lagerheim ( $R$ )

Microspora stagnomum (Kützing) Lagerheim (R)

Microspora WiZteana Lagerheim (A)

Microthamion strietissimum Rabenhorst ( $R$ )

Mougeotia sp. (c)

oocystis eliiptica West (R)

Pandorina morum (Müller) Bory (A)

Pediastrum biradiatum Meyen (R)

Pediastmu Boryanum (Turpin) Meneghini (C)

Pediastrum dup Zex Meyen (A)

Pediastmm simplex (Meyen) Lemmermann ( $R$ )

platydorina caudata Kofoid (R)

Pleodorina califormica Shaw (R)

Rhizoclonium hieroglyphicum (Agardh) kützing (R)

Scenedesmus arcuatus Lemmermann (R)

Scenedesmus bijuga (Turpin) Lagerheim (R)

Scenedesmus Zongus Meyen ( $R$ )

Scenedesmus quadricauda (Turpin) DeBrébisson (R)

Sorastmum spinulosum Nägeli (R)

Sphaerooystis Schroeteri Chodat (A) 
Table 23.- - Composite list of algae observed in phytoplankton of Oneida Lake (Continued)

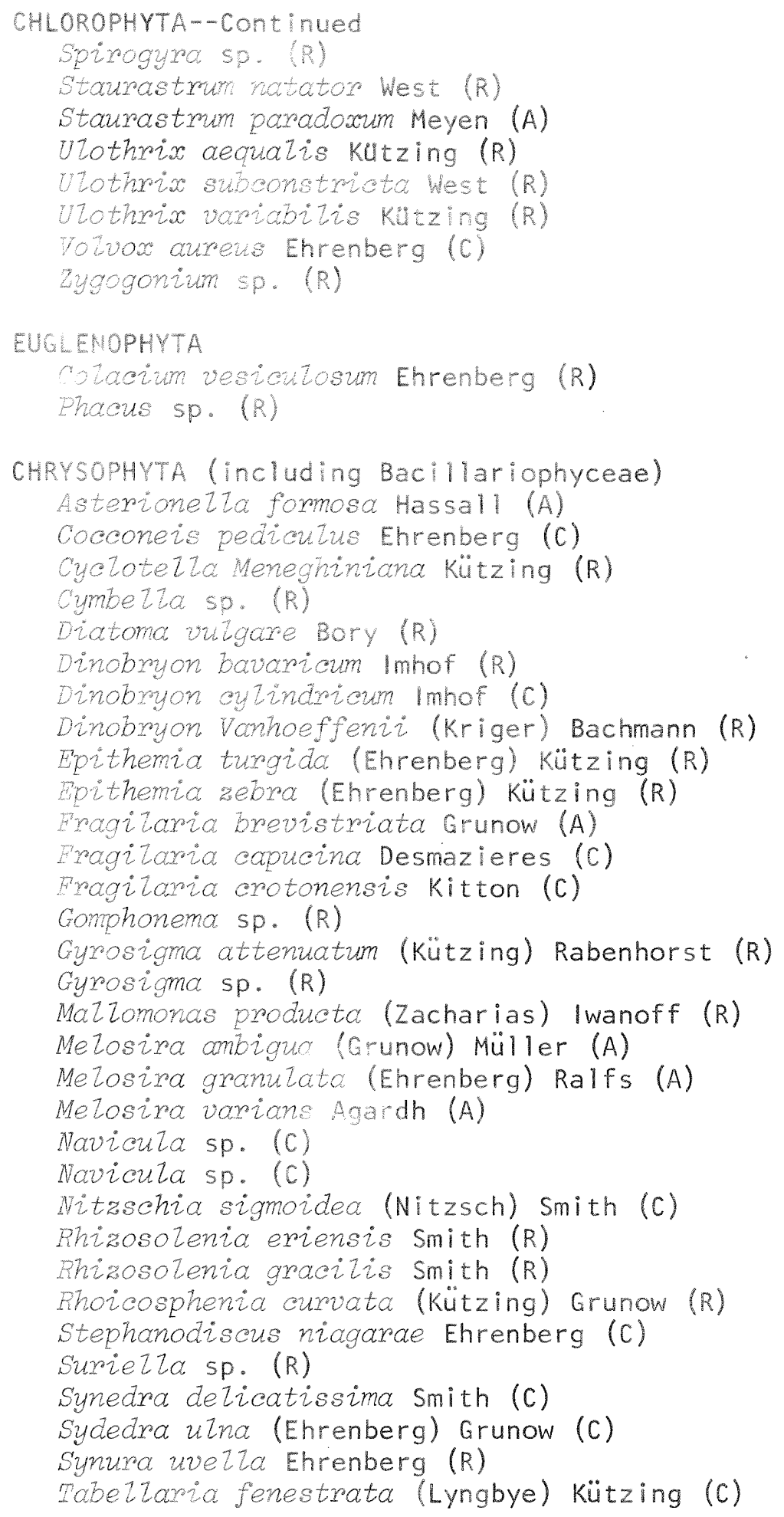


Table 23.--Composite list of algae observed in phytoplankton of Oneida Lake (Continued)

PYRROPHYTA

Ceratium himudinezza (Müller) Schrank (C)

Glenodinium Gymnodinium Penard (R)

Pexidinium cinctum (Muller) Ehrenberg (R)

CYANOPHYTA

Anabaena circinalis Rabenhorst (A)

Anabaena flos-aquae (Lyngbye) DeBrébisson (A)

Anabaena spiroides Klebahn (A)

Aphanizomenon holsaticum Richter (A)

Aphanothece clathrata West (R)

Chroococcus Iimneticus Lemmermann (C)

Cylinarospermum stagnale (Kützing) Bornet \& Flahault (R)

Entophysalis Zemaniae (Agardh) Drouet \& Daily $(R)$

Gloeotrichia echinulata (Smith) Richter (A)

Lyngbya aestuarit (Mertens) Liebmann (R)

Lyngbya Birgei Smith (A)

Iyngbya contorta Lemmermann ( $R$ )

Lyngbya Zimnetica Lemmermann $(R-C)$

Merismopedia elegans Braun (R)

Microcystis aemiginosa Elenkin (A)

Microcystis incerta Lemmermann (A)

Nostocopsis Lobatus wood (R)

Oscillatoria Zacustris (Klebahn) Geitler (R)

oscizlatoria Zimnetica Lemmermann (R)

Oscillatoria Iimnosa (Roth) Agardh (R)

Oscillatoria subbrevis Schmidle (C)

Oscizlatoria tenius Agardh (R)

Pelogloea bacillifera Lauterborn (R)

Synechococcus aemginosa Nägeli (C) 
Table 24. - - $\frac{\text {-ther algae recently reported in the }}{\text { phytoplankton of Oneida Lake }}$

(Numbers refer to references)

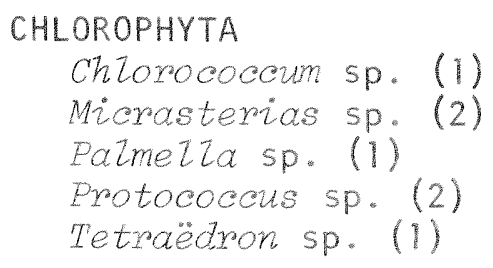

CHLOROPHYTA

ChZorococcum sp. (1)

Micrasterias sp. (2)

Paimeiza sp. (1)

Protococous sp. (2)

Tetraëdron sp. (1)

EUGLENOPHYTA

Euglena sp. $(1,2)$

CHRYSOPHYTA

Bumilieria sp. (1)

Meridion sp. (1)

CYANOPHYTA

Catothrix sp. (2)

Coelosphaerium sp. (2)

Gloeocapsa sp. $(1,2)$

Gomphosphaema sp. (1)

Pivularia sp. (2)

(1) M. C. Lehne, written commun., 1967.

(2) Mt. Pleasant and others, 1961. 

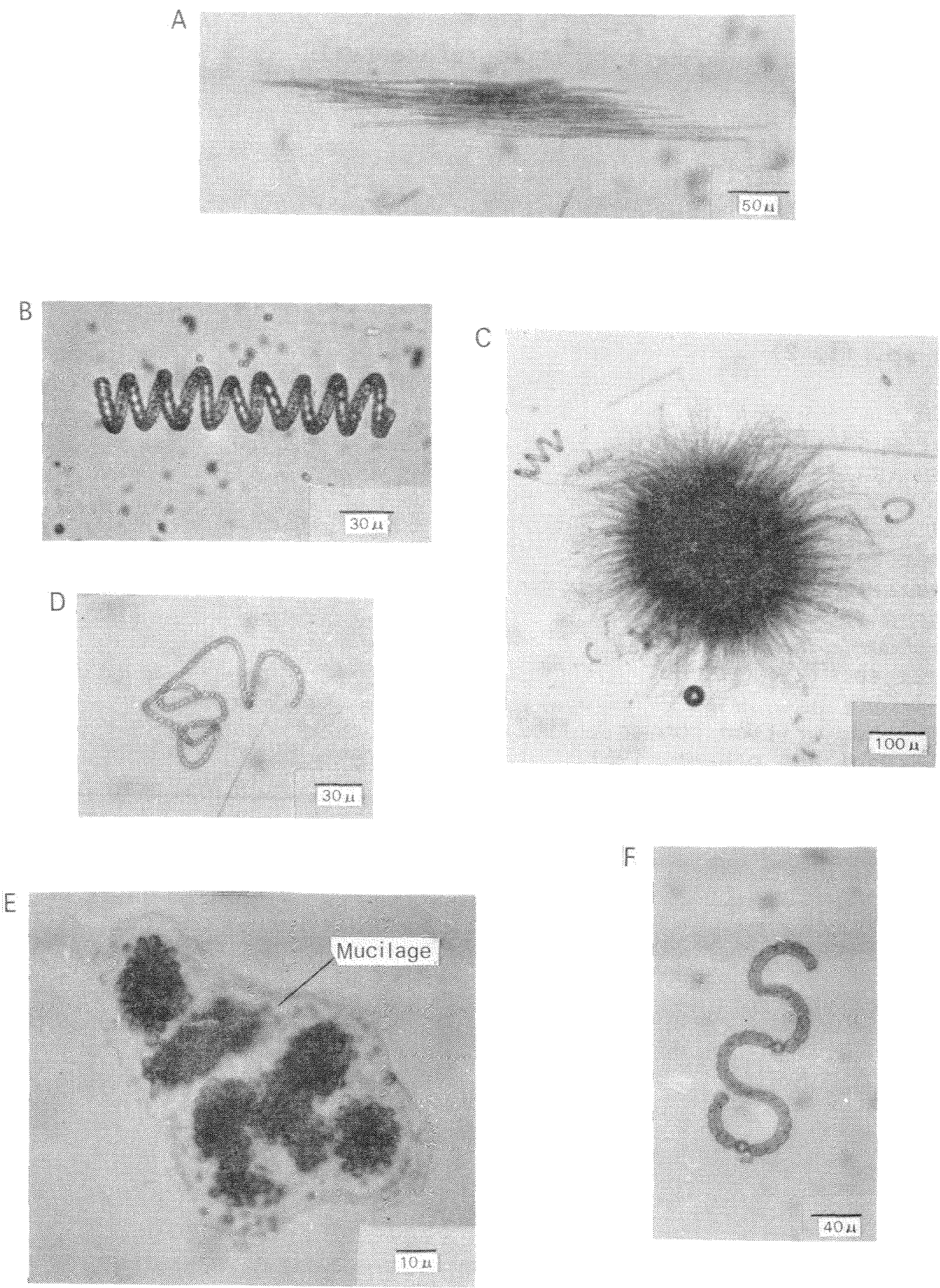

404

Figure 45.--Representative blue-green algae from Oneida Lake.
A. Aphanizomenon holsaticum.
D. Anabaena flos-aquae.
B. Anabaena spiroides.
C. Gloeotmichia echinulata.
E. Microcystis aeruginosa.
F. Anabaena circinalis. 
A

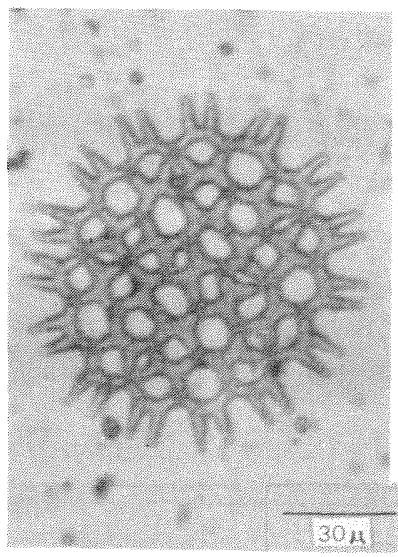

C

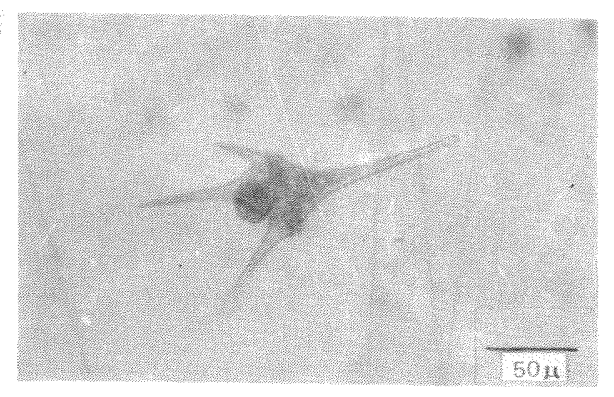

F

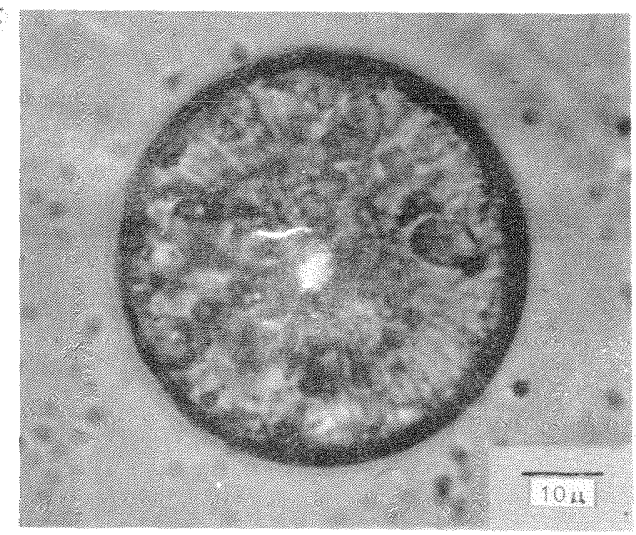

B

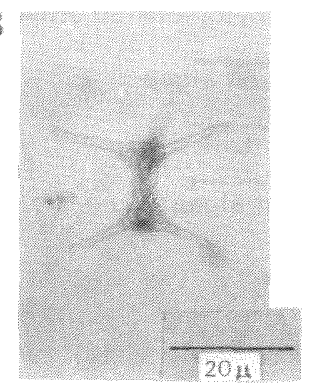

D

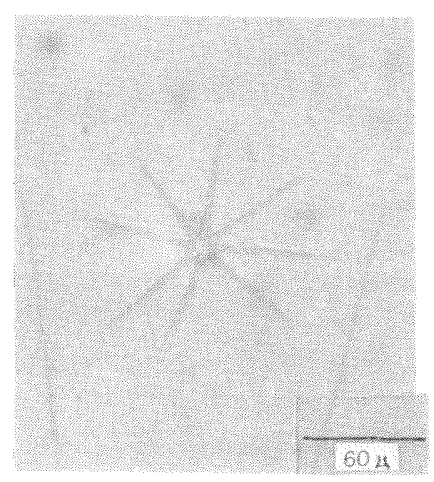

\section{G}
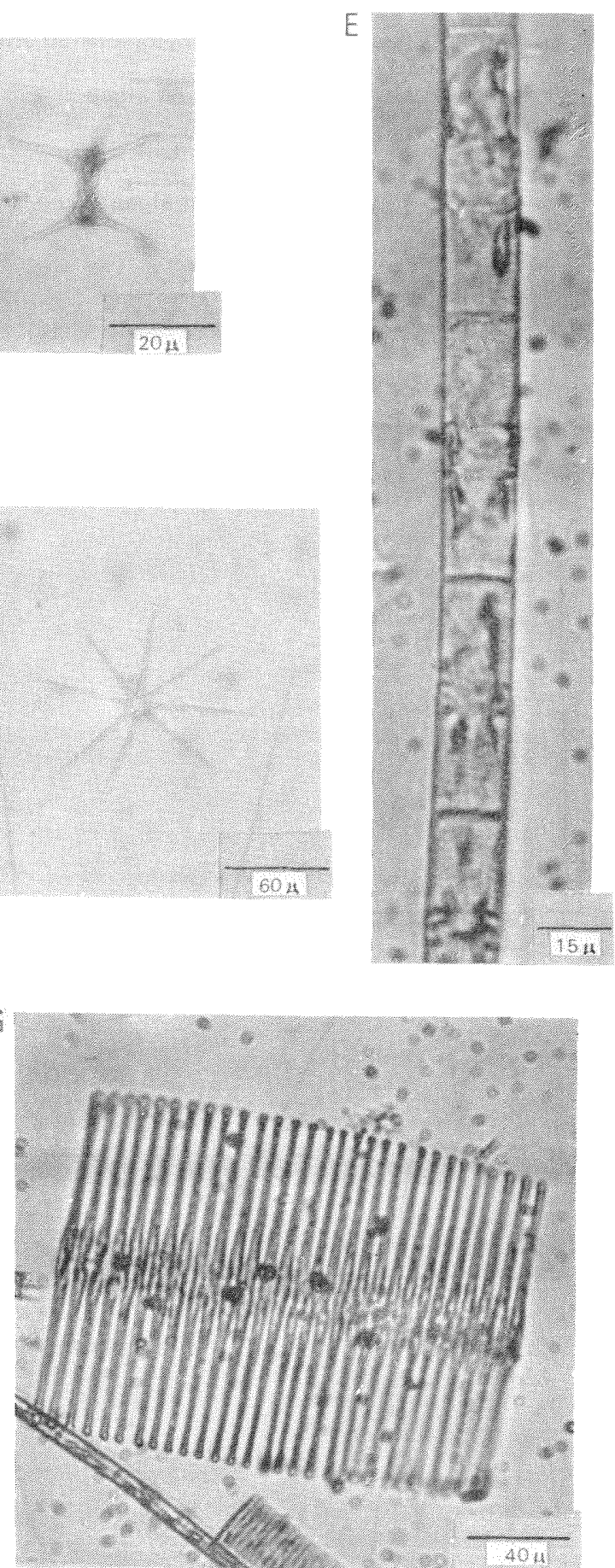

\section{.}




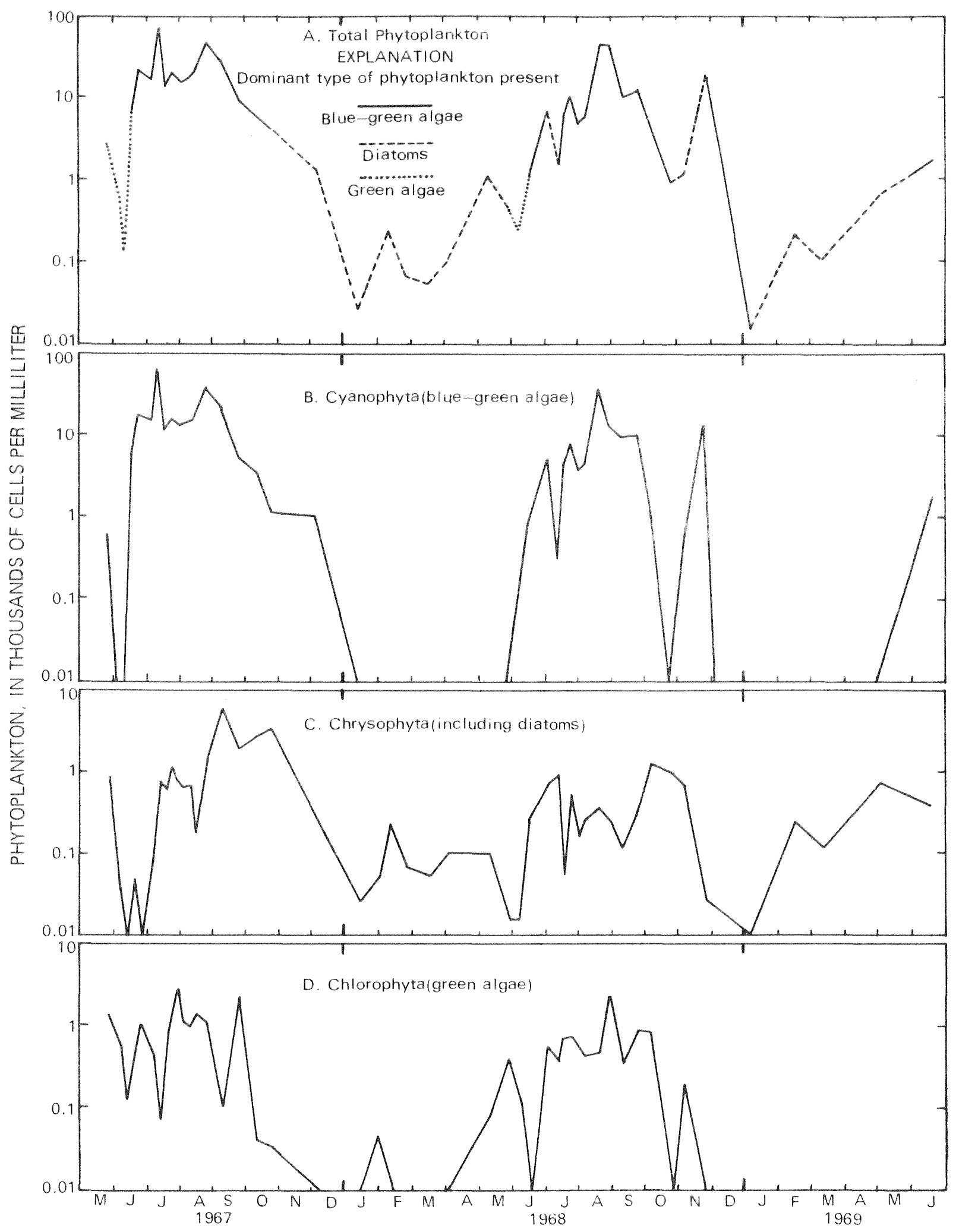

Figure 47.--Relative abundances of the major groups of algae composing the phytoplankton of Oneida Lake. 
Table 25.--Distribution of algae observed two or more times in the phytoplankton of Oneida Lake

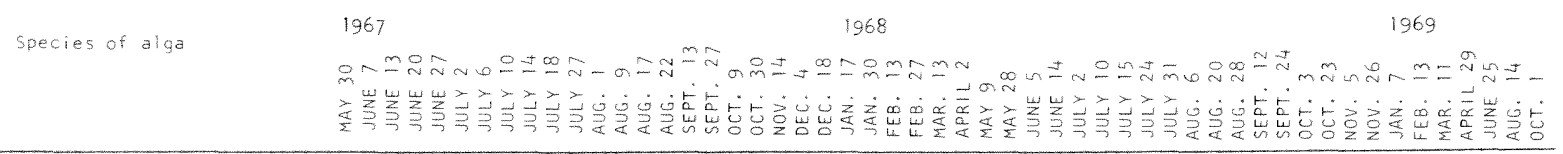

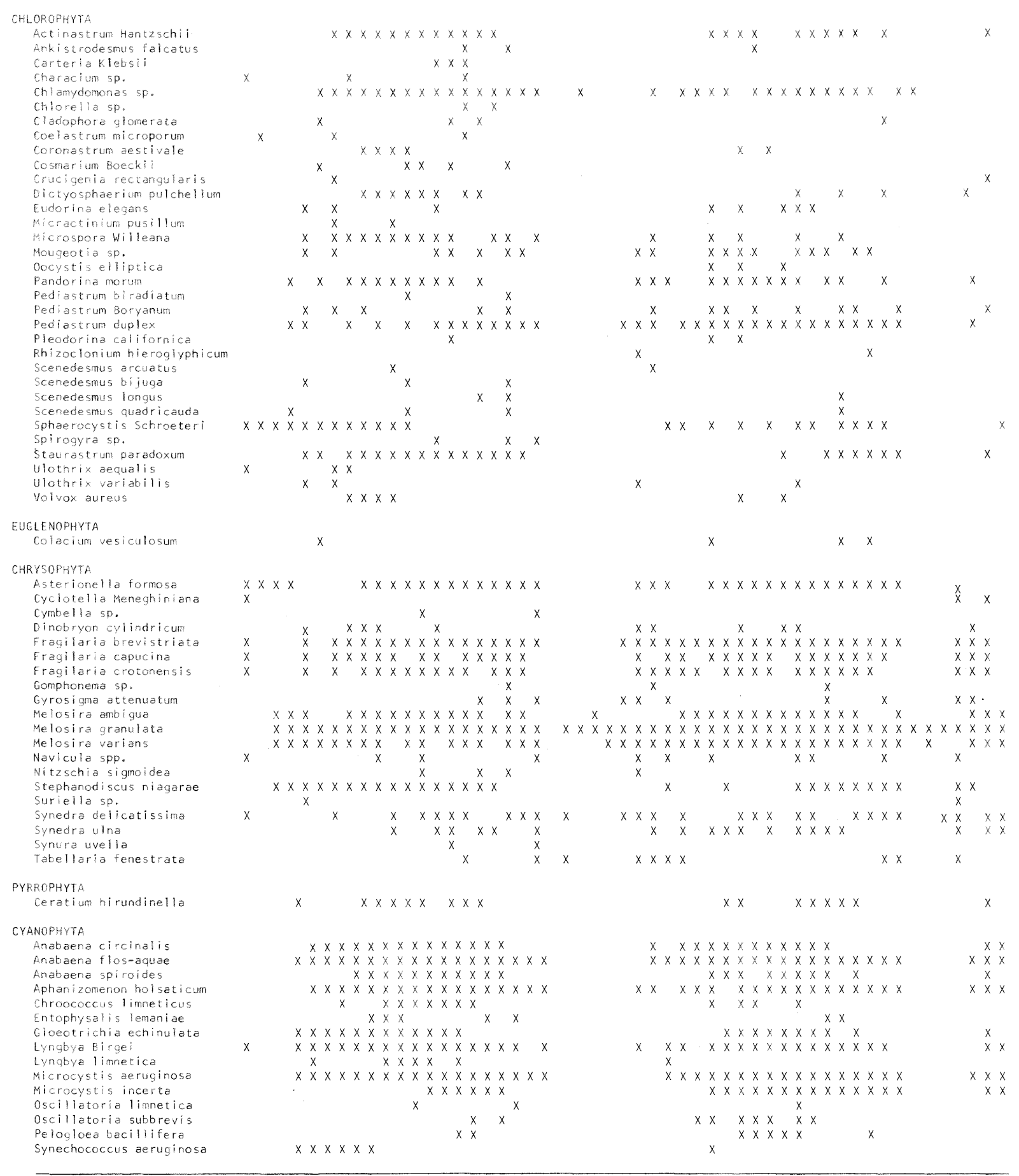


Table 26. - -Dominant phytoplankton organisms in Oneida Lake

(Values represent mean concentrations in cells per milliliter; parenthetic values are percent of standing crop)

May 29,1967

Ulothrix aequalis 1,690, (56.3); Lyngbya Birgei 470, (15.7);

Asterionelza formosa 400, (13.3); Fragizaria spp. 340, (11.3).

June 6, 1967

Sphaerocystis Schroeteri 565. (78.5); Coelastrum microporm 115.

(16.0); Asterionelza formosa 40, (5.5).

June 13,1967

Sphaerocystis Schroeteri 115, (84.6); Melosira spp. 15, (11.0);

Stephanodiscus niagarae 5, (3.7).

June 20, 1967

Anabaena flos-aquae 6,170, (91.4); Sphaerocystis Schroeteri 430, (7.2); MeZosira spp. 60, (0.9); Scenedesmus quadricauda 30, (0.4).

June 27, 1967

Anabaena flos-aquae 18,300, (87.2); Microcystis colonies; Anabaena circinatie 565, (2.7); Synechococcus aeruginosa 355, (1.7).

July 6,1967

Anabaena flos-aquae 15,930, (89.5); Microcystis colonies; Aphanizomenon holsaticum 1,265, (6.7); Coelastrum microporum 265, (1.5).

July 10,1967

Anabaena flos-aquae 50,700, (71.1); Aphanizomenon holsaticum 19,750, (27.7); Microcystis colonies; Synechococcus aemininosa 185, (0.3).

July 14,1967

Aphanizomenon holsaticum 6,395, (45.4); Anabaena flos-aquae 5,340, (38.5); Microcystis colonies; Melosira spp. 595, (4.2).

July 18,1967

Aphanizomenon holsaticum 8,410, (39.1); Anabaena flos-aquae 7,635, (35.5); Microcystis colonies; Anabaena circinalis 2,290, (10.7).

Juily 27,1967

Anabaena flos-aquae 8,650, (43.1); Aphanizomenon holsaticum 5,910, (29.4); Pandorina morum 1,830, (9.1); Anabaena circinatis 1,115, (5.6).

August 1, 1967

Anabaena flos-aquae 14,900, (63.8); Aphanizomenon holsaticum 6,200, (26.8); Pandoxina morum 500, (2.3); Microcystis colonies.

August 9, 1967

Aphani:omenon holsaticum 11,355, (61.7); Anabaena flos-aquae 3,780, (20.5); Anabaena circinalis 1,170, (6.4); Dictyosphaerium pulchelzum $530,(2.9)$. 
Table 26.--Dominant phytoplankton organisms in Oneida Lake

(continued)

August 17, 1967

Aphanizomenon holsaticum 10,900, (51.4); Anabaena circinalis 3,770, (17.8); Anabaena flos-aquae 3,330, (15.7); Anabaena spiroides 1,260, (5.9).

August 22, 1967

Aphanizomenon holsaticum 16,900, (42.6); Anabaena flos-aquae 9,930, (25.0); Anabaena circinalis, 9,730, (24.5); Microcystis colonies.

September 13, 1967

Anabaena circinalis 9,900, (37.0); Aphanizomenon holsaticum 7,850, (29.3); Melosira spp. 4,235, (15.8); Fragizaria spp. 1,785, (6.7).

September 27,1967

Anabaena circinalis 3,915, (40.8); Melosira spp. 1,685, (17.6);

Aphanizomenon holsaticum 935, (9.7); Pandorina momm 800, (8.3).

October 9, 1967

Anabaena circinatis 2,950, (46.1); Eragizaria spp. 1,560, (24.4);

Melosira spp. 940, (14.7); Aphanizomenon holsaticum 560, (8.8).

October 30,1967

Melosira spp. 2,350, (50.0); Anabaena flos-aquae 1,085, (23.1);

Fragizaria spp. 835, (17.8); Microcystis colonies.

December 4, 1967

Anabaena flos-aquae 1,000, (80.0); Melosira spp. 200, (16.0);

spp. 40, (3.2).

January 17, 1968

Synedra spp. 15, (60.0); MeZosira spp. 10, (40.0).

January 30,1968

Mezosira spp. 20, (66.7); ChZamydomonas sp. 10, (33.3).

February 13, 1968

Metosira spp. $120(100.0)$.

February 27, 1968

Melosira spp. 60, $(100.0)$.

March 13, 1968

Melosira spp. 45, (86.5); Fragizaria spp. 5, (9.6).

April 2, 1968

Melosira spp. 90, $(90.0)$; Nitzschia sigmoidea 5, (5.0).

May 9,1968

Fragilaria spp. 450, (44.1); Tabeltaria fenestrata 210, (20.6);

Melosira spp. 175, (17.2); Asterionelia formosa 110, (10.8). 
Table 26. --Dominant phytoplankton organisms in Oneida Lake

(Continued)

May 28,1968

Sphaerocystis Schroeteri 405, (95.3): Anabaena flos-aquae 10, (2.4):

Melosira spp. 5, (1.2).

June 5,1968

Sphaerocystis Schroeteri 125, (59.5); Anabaena flos-aquae 50, (23.8);

Melosira spp. 15, (7.1); EragiZaria spp. 10, (4.8).

June 14, 1968

Anabaena flos-aquae 820, (76.3); Melosira spp. 230, (21.4); Eragizaria spp. 10, $(0.9) ;$ Chramydomonas sp. 10, (0.9).

July 2,1968

Anabaena flos-aquae 3,650, (54.6); Microcystis colonies; Aphanizomenon holsatioum 2,360, (35.3); Pleodomina califomica 555, (8.3).

July 10,1968

Melosira spp. 525, (56.8); Mougeotia sp. 175, (18.9); Actinastmum Hantaschiz 90, (9.7); Synedra spp. 35, (3.8).

July 15,1968

Anabaena flos-aquae 4.525, (85.4); ChLamydomonas sp. 700, (13.2);

Ceratium hirundinezta 25, (0.5); Melosira spp. 25, (0.5).

July 24,1968

Aphanizomenon holsaticum 7,150, (73.0); Anabaena circinalis 1,500,

(15.3); Actinastrum Hantzschii 700, (7.1); Metosira spp. 450, (4.6).

July 31,1968

Aphanizomenon holsaticum 3,700, (81.3); Pediastrum duplex 460, (10.1);

Melosira spp. 130, (2.9); Sphaerocystis Schroeteri 80, (1.8).

August 6,1968

Anabaena flos-aquae 2,290, (40.9); Aphanizomenon holsaticum 2,130, (38.4); Anabaena circinatis 523, (9.4); ChZamydomonas sp. 350, (6.2).

August 20,1968

Anabaena flos-aquae 6,030, (42.4); Oscilzatoma Iimetica 4,000, (28.1); Aphanizomenon holsaticum 2,470, (17.4); Anabaena circinalis $575,(3.9)$.

August 28,1968

Aphanizomenon holsaticum 5,865, (39.9); Anabaena flos-aquae 5,210, (35.5); Sphaerocystis Schroeteri 2,130, (14.5); Anabaena circinatis $575,(3.9)$.

September 12, 1968

Anabaena flos-aquae 6,250, (64.4); Aphanizomenon holsaticum 2,425, (25.0): Anabaena circinatis 575, (5.9); Actinastmm Hantzschii 200, $(2.1)$. 
Table 26.--Dominant phytoplankton organisms in Oneida Lake

(Continued)

September 24,1968

Aphanizomenon holsaticum 7,830, (70.2); Anabaena flos-aquae 2,060, (18.5); Actinastrum Hantzschii 465, (4.2); Melosira spp. 310, (2.8).

October 3,1968

Melosira spp. 2,540, (55.1); Aphanizomenon holsaticum 1,440, (31.2); Pediastrum duplex 300, (6.5); Eragilaria spp. 200, (4.3).

October 23,1968

Fragitaria spp. 525, (61.8); Stephanodiscus niagarae 300, (35.3).

November 5,1968

Aphanizomenon holsaticum 450, (36.0); Asterionelia formosa 425, (34.0); Actinastrum Hantzschii 200, (16.0); Gyrosigma attenuatum 25, $(2.0)$.

November 26,1968

Aphanizomenon holsaticum 10,810, (99.6); Stephanodiscus niagarae 25, $(0.2)$.

January 7,1969

MeZosira spp. 5, (100.0).

February 13, 1969

Melosira spp. 205, $(100.0)$.

March 11, 1969

Melosira spp. 75, (75.0); Synedra spp. 15, (15.0).

April 29, 1969

Fragizaria spp. 290, (47.5); Tabelzaria fenestrata $150,(24.6)$;

Asterionelza formosa 115, (18.9); Synedra spp. 30, (4.9). 

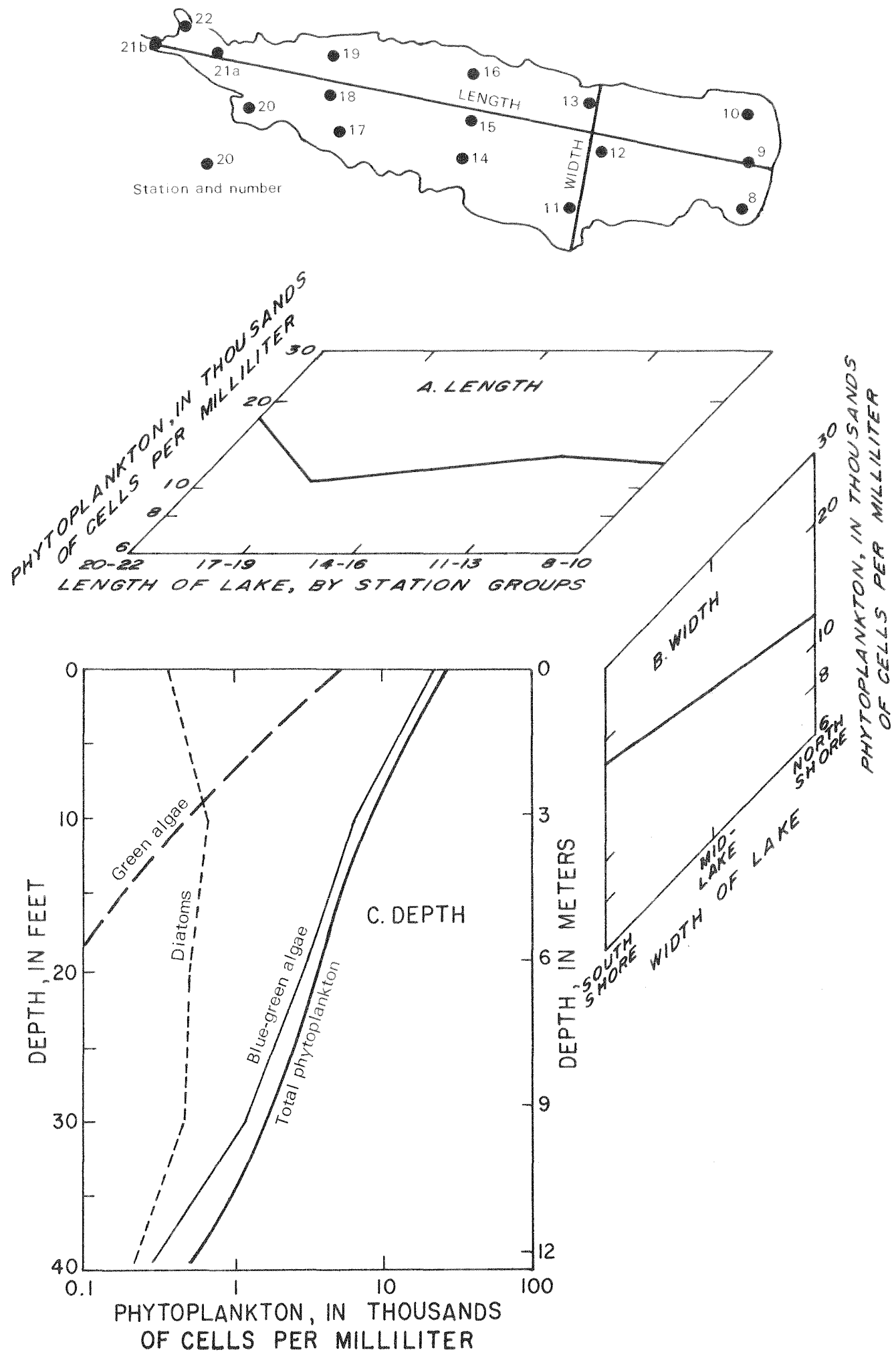

Figure 48.--Spatial variations of phytoplankton during the growing seasons 1967 and 1968. 


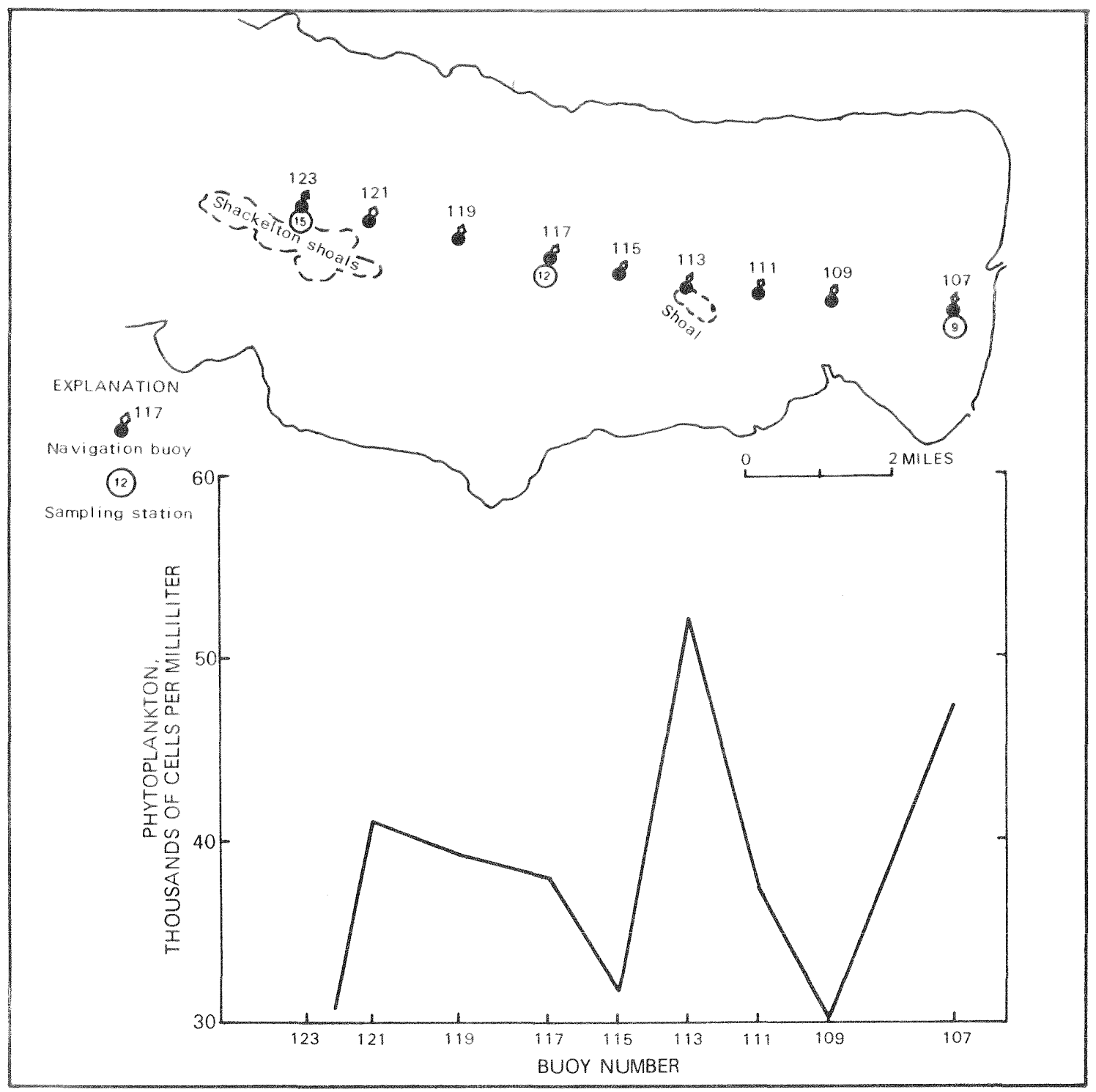

Figure 49.--Variations of phytoplankton in eastern Oneida Lake, August 22, 1967. 


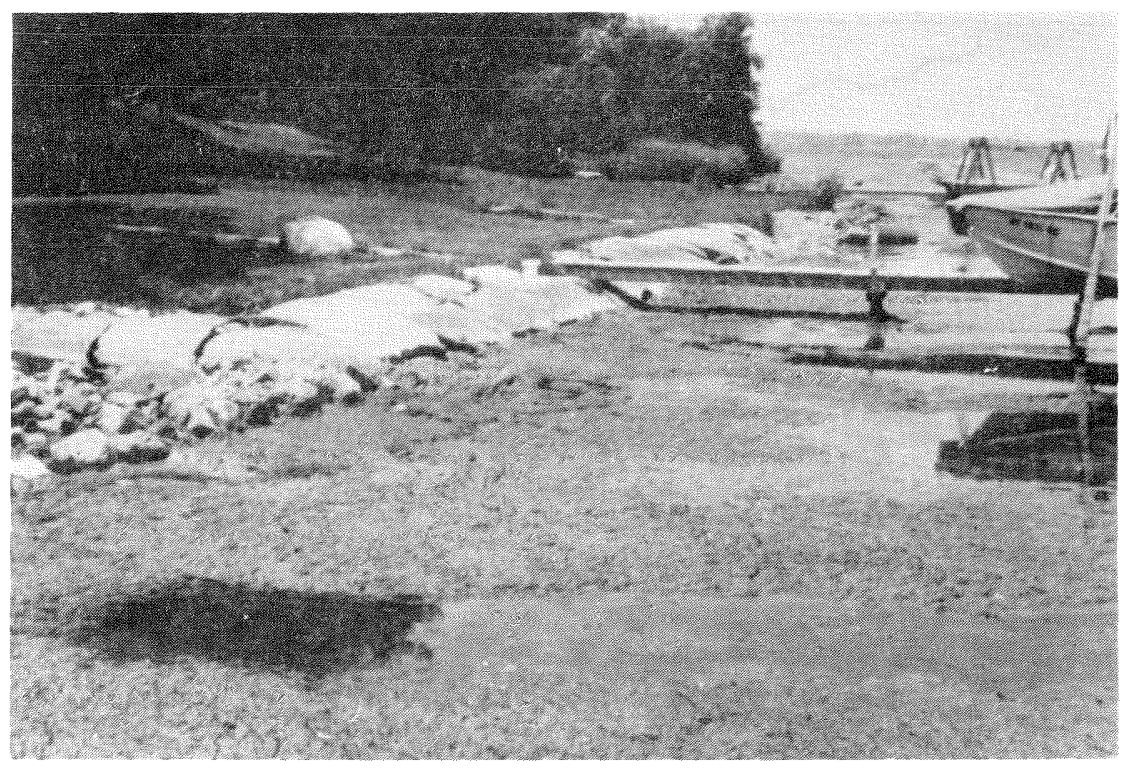

Figure 50.--Decomposing algal mats near Bushnell Point, August 17, 1967. 
New York State and the Federal Government cooperatively studied the limnology of Oneida Lake and its drainage basin to define environmental conditions associated with annual production of enormous populations of algae in the lake. Initially, three assumptions were made about oneida Lake: (1) An understanding of hydrological, physical, chemical, and biological processes is a necessary first step toward algal control. To alter a natural system successfully, cause and effect relationships within the system must be defined. (2) Oneida Lake is part of a complex hydrological entity that serves as the end point of a large drainage network. Events within the network can influence, either directly or indirectly, events within the lake. (3) Oneida Lake is in a state of dynamic equilibrium, tending toward but seldom attaining stability. Algae in the lake are part of the problem of eutrophication, and control measures for the problem must $c$ nsider the fundamental causes.

The approach used in the study was to consider how one major environmental factor affected another. Emphasis was placed on the discovery of phenomena that were operationally significant to the physiological processes of the algae and on the determination of how the phenomena affected the algal populations. This section of the final report is restricted to the principal involved relationships and is directed toward the control of algal problems in Oneida Lake.

Two interim reports on the study have been completed. The first considered the limnology of Oneida Lake (Greeson and Meyers, 1969); the second discussed the hydrochemistry of Oneida Lake basin (Pearson and Meyers, in press). The latter report stated that the quantities of major chemical species dissolved in the streams of the basin were established by the geochemistry of five internally homogeneous terranes and that cultural influences on the quantities were minimal. The report concluded that the content of major chemical species dissolved in Oneida Lake was determined by the combined quality of the inflowing streams.

The report by Greeson and Meyers (1969) concluded that the four most important factors affecting the biological processes in Oneida Lake were (1) high fertility of the drainage basin, (2) physical position and shallowness of the lake, (3) mixing caused by wind, and (4) fertility of the bottom sediments. The report further concluded that Oneida Lake was a naturally eutrophic lake and that nutrients entering the lake from natural sources alone were of sufficient quantity to support the annual algal blooms.

Figure 51 shows that when a lake has reached the eutrophic stage, aging is hastened. Because no pronounced changes have occurred in oneida Lake during the period of technical record, the rate of eutrophy in the lake has probably plateaued in the latter part of the eutrophic stage. Future long-term changes in lake conditions, if uninfluenced by outside factors, should progress at a slow rate.

Previous discussion has considered the effect of outside factors on the rate of eutrophication in Oneida Lake. Cultural contributions of nitrogen and phosphorus to the lake were responsible for 17.1 percent and 19.8 percent of the total budgets for the two elements, respectively. As a 


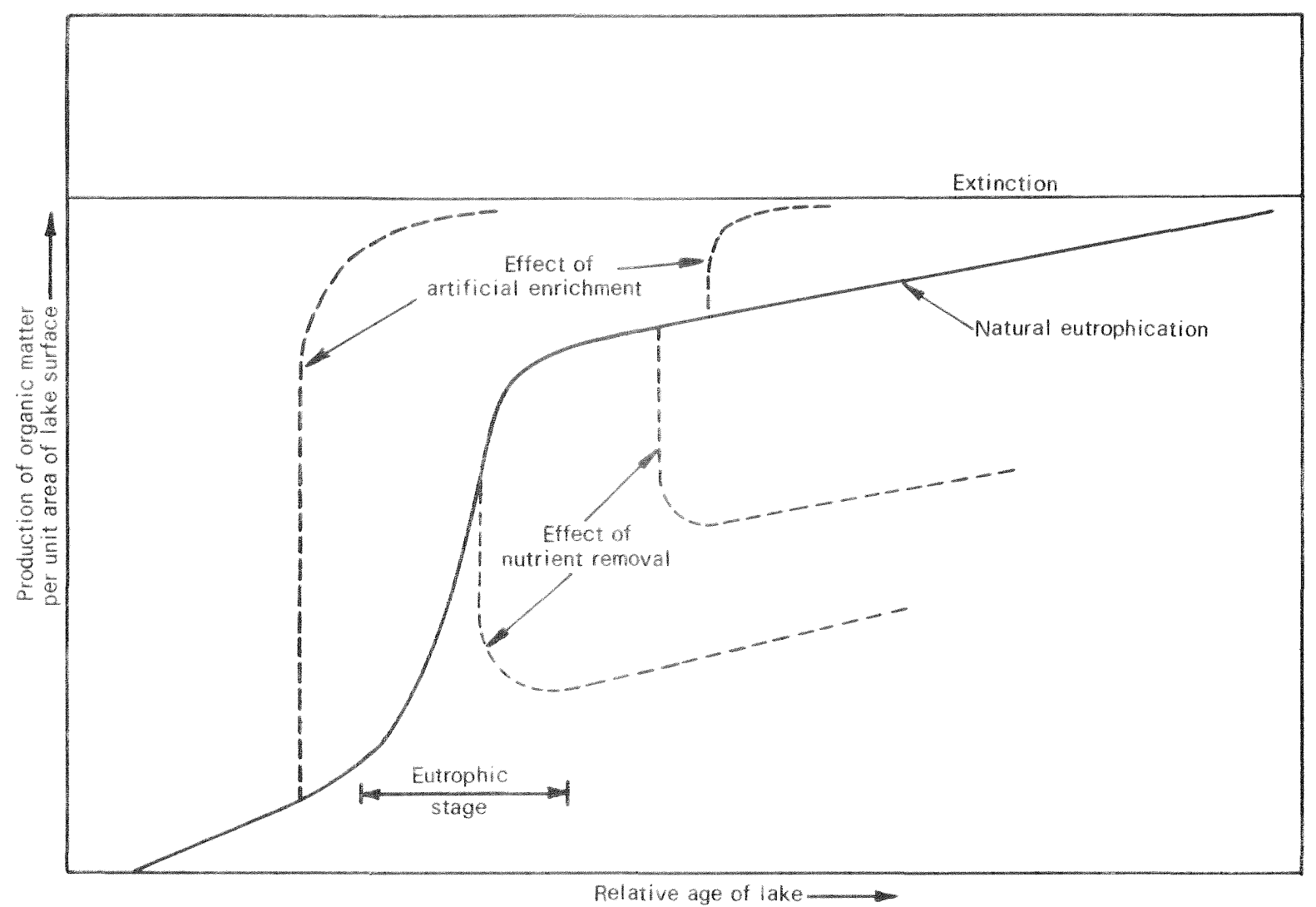

Figure 51.--Hypothetical curve of eutrophication (modified from Hasler, 1947).

result, cultural contributions have slightly enhanced the rate of enrichment and have subsequently increased the rate of eutrophication in oneida Lake. Effects of this artificial enrichment can be abated by elimination or control of cultural sources.

Effect of increased nutrient enrichment in a lake is well known and apparent. Cessation of artificial enrichment also has been shown to have dramatic effects on lake dynamics. The classic case is Lake Washington in the State of Washington (Edmondson, and others, 1956; and Edmondson, 1970), which immediately changed from a peamsouplike mixture to a clear-watered lake after diversion of municipal wastes from the lake.

Exact reasons for excessive productivity in Oneida Lake and in Lake Washington differ, but the reasons for improvement of Lake Washington exemplify the important relationship of cause and effect. The relationship is similar to a balanced equation. For example, if nutrients are added to a lake (a cause), productivity increases (an effect); and, conversely, if nutrients are removed from a lake, productivity decreases.

Abatement of artificial enrichment can have a tremendous effect on a lake; and further removal of naturally supplied nutrients should have an even greater effect, especially in a lake that has a short flow-through time. A short flow-through time results in fluctuations in nutrient content with changes in nutrient inflow. Such characteristics are typical of 
Oneida Lake; therefore, a reduction in quantity of inflowing nutrients to the lake would reduce the nutrient content of the lake. This condition would decrease the potential for biological production. Quantities of inflowing, naturally derived nutrients to oneida Lake could be reduced by stream diversion.

Several observations during the study suggested stream diversion as a possible means of controlling excessive biological primary productivity in Oneida Lake. An important observation was the displacement of lake water by north tributary water under ice cover. Figure 38 shows that by late March of each year, the greatest percentage of water in Oneida Lake consists of low-mineralized water that entered the lake from the east through the New York State Barge Canal. Sources of water to the canal were from East and West Branches of Fish Creek and from Wood Creek.

Lowest dissolved-solids content of the lake occurred annually during the spring runoff. It resulted from the combined low-mineralized water that had entered the lake in the winter and the large volume of water from the north during snowmelt and spring-runoff periods. Average dissolvedsolids content of the lake increased in the summer, as the heavily mineralized water from the south mixed with lake water.

In the growing season of 1967, Oneida Lake contained a large population of blue-green algae. Several algal blooms were observed in the summer. According to local residents, the largest blue-green algal population ever observed in the lake occurred in the summer of 1969. The summer of 1968 was unique in that blue-green algae in the lake never reached nuisance or bloom quantities.

Examination of physical, chemical, and biological data did not reveal reasons for annual variations in algal production. The only apparent significant changes in environmental conditions were small variations in the mean annual dissolved-solids content of the lake. As discussed earlier, dissolved-solids content averaged 171 and $161 \mathrm{mg} / 1$ in the growing seasons of 1967 and 1968, respectively. An average value could not be established for the growing season of 1969, because routine collection of data had been terminated. However, a few specially collected samples during 1969 indicated that the average dissolved-solids content in 1969 was higher than it was in 1968.

High dissolved-solids contents of Oneida Lake in 1967 and 1969 accompanied the high production of algae. Low dissolved-solids content in 1968 accompanied algal production. The relationships indicated that dissolvedsolids content was an important index of potential productivity conditions because no element, ion, or compound was a limiting factor on algal production. Dissolved-solids content integrates the total nutritional complex with interactions of environmental factors. Larkin and Northcote (1968) and Rawson (1960) previously discussed the importance of dissolved-solids content as a lake index.

Mean annual variations of dissolved-solids content, as associated with annual production of phytoplankton in the lake, and seasonal fluctuation of dissolved-solids content suggested that the hydrologic regime of oneida 
Lake was an important influencing factor on biological primary productivity. As the annual water budget changed, dissolved-solids content in the lake could be expected to change.

Previous discussion of the water budget of Oneida Lake stated that the amount of water flowing through the system during 1967 water year was about 24 percent below the long-term average. In 1968 and 1969 water years, it was about 11 and 21 percent, respectively, above the long-term average. The pattern of change of the three annual water budgets did not explain variations of dissolved-solids content of the lake. A breakdown of water contributions to the lake, however, showed the expected annual patterns.

In winter and spring seasons 1966-67, information derived from records of the U.S. Geological Survey (1968) showed that 615,712 acre-feet of water entered Oneida Lake from the north tributaries. This volume of water was 63.4 percent of the total inflow to the lake and represented 54.4 percent of the volume of the lake.

In the comparable period 1967-68, 732,256 acre-feet or 65.9 percent of the water entering oneida Lake came from the north tributaries (U.S. Geological Survey, 1969b). The north inflow was 116,544 acre-feet greater than that for the previous year. It virtually displaced the water in the lake with low-mineralized water. In the following growing season, algal blooms were of no consequence.

Weather Bureau records for winter and spring 1968-69 indicated that precipitation in Oneida Lake drainage basin was considerably greater than for the two previous winters and springs (0. P. Hunt, written commun., 1969). The greater precipitation resulted in a larger spring runoff and an annual water budget 21 percent above the long-term average. Even though the volume of water from the north tributaries amounted to 869,427 acrefeet in winter and spring seasons of 1968-69, the amount of water from the south tributaries was proportionally larger than during the two previous winters and springs (U.S. Geological Survey, 1970b). The result was a percentage decrease of inflowing water from the north. It amounted to 57.2 percent of the water budget.

The mixture of water from north and south tributaries produced a comparatively high dissolved-solids content in oneida Lake in the growing season of 1969. In that summer, severity of algal blooms in Oneida Lake was reported to have been the worst ever observed.

Water budgets, dissolvedusolids contents, and algal populations of Oneida Lake during the study are summarized in table 27. The table implies that a relatively large percentage of water from south tributaries produces a relatively high dissolved-solids content in the lake and that a large algal population results.

Unfortunately, the periods in which algal blooms have been reported in the past do not coincide with historical records of streamflow; therefore, no conclusive comparisons can be made with past data. Muenscher (1928) stated that algae were of no consequence in 1927, when a 25 percent larger than average volume of water entered oneida Lake from the north 
Table 27.--Summary of water budgets, dissolved-solids contents, and algal blooms in oneida Lake, May 1967 through

September 1969

\begin{tabular}{|c|c|c|c|c|}
\hline \multirow{2}{*}{ Year } & \multicolumn{2}{|c|}{$\begin{array}{l}\text { Water budget (during } \\
\text { winter and spring) }\end{array}$} & \multirow{2}{*}{$\begin{array}{c}\text { Dissolved-solids } \\
\text { content } \\
(\mathrm{mg} / 1)\end{array}$} & \multirow{2}{*}{$\begin{array}{c}\text { Algal populations } \\
\text { (severity) }\end{array}$} \\
\hline & $\begin{array}{l}\text { Percent } \\
\text { from north }\end{array}$ & $\begin{array}{l}\text { Percent } \\
\text { from south }\end{array}$ & & \\
\hline 1967 & 63.4 & 36.6 & 171 & $\begin{array}{l}\text { Numerous algal } \\
\text { blooms. }\end{array}$ \\
\hline 1968 & 65.9 & 34.1 & 161 & No algal blooms. \\
\hline 1969 & 57.2 & 42.8 & $\begin{array}{l}\text { Greater than } \\
\text { during } 1968 .\end{array}$ & $\begin{array}{l}\text { Largest popula- } \\
\text { tion ever ob- } \\
\text { served. }\end{array}$ \\
\hline
\end{tabular}

drainage basin. Burdick and Lipschuetz (1946) reported algal blooms in 1942 and 1944. Hydrologic records, although incomplete, showed that East Branch Fish Creek, a north stream, carried 1 percent and 19 percent less water than the long-term average in 1942 and 1944, respectively.

Because of observations in the current study and of suggested environmental relationships in past studies, the author concluded that years of drought and years in which the contribution of water from the south streams is larger than usual were associated with nuisance algal conditions in Oneida Lake. Therefore, the hydrologic regime of oneida Lake and its drainage basin is a principal factor in the production of algae. Control of algal blooms might be accomplished by diversion of the south tributaries around or away from the lake.

The obvious question to such a postulation is what would be the effect of such a change on the dynamics of Oneida Lake. The answer is not so obvious, but prediction can be made with some degree of certainty. First, an alteration of the hydrologic regime would have little effect on many of the lake's physical processes including thermal variations, wave action, seiches, currents, mixing, shifting of sedimented materials, formation and deterioration of ice cover, light penetration, and solar insolation. All these processes have been shown to be important environmental factors, and they would be virtually unchanged.

Most pronounced changes would occur in the annual water budget and in concentrations of chemical substances (for example, plant nutrients). These changes, particularly the latter, would reduce the degree of biological primary productivity. 
If the discharge of water into Oneida Lake from the four south tributaries (that is Oneida, Canaseraga, Cowaselon, and Chittenango Creeks) was diverted, annual inflow of water to the lake would be decreased by about 28 percent or about 521,300 acre-feet per year (table 28). Hydrologic equilibrium of the lake would depend on water from the north tributaries (that is, Scriba, West Branch Fish, East Branch Fish, and Wood Creeks), from the ungaged areas surrounding the lake, and from precipitation onto the lake surface. These three sources represent a combined contribution of about 1,357,200 acre-feet per year or about 72 percent of inflowing water.

If the amount of water entering the lake is decreased, the amount of water leaving the lake would be decreased if the lake stage is maintained at 369-foot altitude, the normal summer stage. With such a change, the outflow of water through the Oneida River would be decreased to about $1,209,100$ acre-feet per year. The decrease in outflow would reduce the mean annual discharge of the Oneida River past Brewerton to about 1,670 cubic feet per second. It is presently about 2,390 cubic feet per second. Evaporation from the lake surface would remain unchanged at about 148, 100 acre-feet per year.

Water now entering Oneida Lake from north tributaries, from ungaged areas, and from precipitation would be adequate to maintain the 369-foot stage of the lake. The $1.3+$ million acre-feet of water per year from these sources is about 120 percent of the volume of the lake or about 227,200 acre-feet greater than the lake's 1,130,300 acre-feet. In drought years, augmentation from the south tributaries might be necessary to maintain the lake stage. During floods, on the other hand, it might be necessary for the lake to receive water from the south to prevent flood damage in the south drainage basin.

Table 28. --.-Predicted water budget of Oneida Lake

\begin{tabular}{|c|c|}
\hline Factor & Acre-feet/year \\
\hline \multicolumn{2}{|l|}{ INFLOW } \\
\hline North tributaries & 922,376 \\
\hline Ungaged areas & 285,256 \\
\hline Precipitation & 149,560 \\
\hline Sum & $1,357,192$ \\
\hline \multicolumn{2}{|l|}{ OUTFLOW } \\
\hline Oneida River & $1,209,080$ \\
\hline Evaporation & 148,112 \\
\hline sum & $1,357,192$ \\
\hline \multicolumn{2}{|l|}{ DIVERSION } \\
\hline South tributaries & 521,280 \\
\hline
\end{tabular}


Reduction of inflow to the lake and accompanying reduction in outflow would increase the flow-through time of water in the lake. Diversion of the four south tributaries would probably increase retention time from 235 days to 340 days, an increase of 105 days, or 45 percent.

It is difficult to predict the result of an increased flow-through time because little study has been done on the topic. However, the greatest change would probably be a delay of seasonal chemical conditions now typical of the lake.

The greatest volume of water enters Oneida Lake during spring runoff. It is derived principally from north tributaries. This water has a relatively low dissolved-solids content compared with water entering the lake during low-flow periods.

After diversion, inflow of water would still be greatest in the spring. At the beginning of the growing season, nutrient concentrations in the lake would be at their annual minimum values. The minimums typically occur in late winter or early spring seasons.

As the year progressed, the volume of inflowing water would decrease as the nutrient concentrations increased. The highest dissolved-solids content of the lake would occur in the winter season, when primary productivity is of minimal significance. The highest dissolved-solids content in the lake occurs in late summer or the last part of the growing season when primary productivity is of significance.

An increased flow-through time would probably have little effect on the transfer of dissolved materials from the bottom sediments into solution, because the current study has found that oxidizing conditions exist at the mudwater interface. Those conditions would remain unchanged after diversion, because the downward transport of water by mixing would remain unchanged.

The most significant alteration of the lake environment because of diversion, and subsequent change in the water budget, would be a decrease in the dissolved-solids content. As was discussed in the section on temporal variations of chemical constituents in Oneida Lake, the quality of Oneida Lake water depends on the quality of inflowing water.

The combined effect of low-mineralized water from the north plus heavily mineralized water from the south is a chemical mixture whose dissolved-solids content averages $163 \mathrm{mg} / 1$. The effect is analogous to mixing salt water with fresh water; a weak salt solution results. If salt water is not added to the container, the fresh water remains pure. Such an analogy would be applicable to the chemical conditions in Oneida Lake if the south tributaries were diverted. Low-mineralized water from the north would become the "pure" water in the lake; it would be supplemented only by water from ungaged areas and from direct precipitation.

Table 29 shows that the average dissolved-solids content of the north tributaries is $54 \mathrm{mg} / 1$, that of ungaged areas is $153 \mathrm{mg} / 1$, and that of precipitation is $9 \mathrm{mg} / 1$. A mixture of water from the three sources would have a dissolved-solids content of about $70 \mathrm{mg} / 1$, which, theoretically, 
Table 29.-- $\frac{\text { Predicted annul chemical budget of dissolved solids }}{\text { in Oneida Lake after diversion of south tributaries }}$

\begin{tabular}{lcc}
\hline Factor & $\begin{array}{c}\text { Chemical load } \\
(\text { tons/yr) }\end{array}$ & $\begin{array}{c}\text { Dissolved- } \\
\text { solids content } \\
(\mathrm{mg} / 1)\end{array}$ \\
\hline $\begin{array}{l}\text { INFLOW } \\
\text { North tributaries } \\
\text { Ungaged areas } \\
\text { Precipitation }\end{array}$ & 67,890 & 54 \\
& 59,130 & 1,825 \\
& 128,845 & 9 \\
OUTFLOW & & $(70)$ \\
Oneida River & 122,403 & \\
Lake retention & 6,442 & \\
& 128,845 & \\
DIVERSION & & \\
South tributaries & 322,660 & \\
\hline
\end{tabular}

would be the approximate dissolved-solids content of Oneida Lake after diversion of the south streams. This theoretical dissolved-solids content is about 43 percent of the dissolved-solids content of the lake during this study. The chemical load contribution to the lake from the three sources would be about 29 percent of the present inflowing load. It would approximate 128,850 tons per year.

If the amount of dissolved materials in the lake were reduced, the percentage retention of dissolved solids would probably be reduced. The concentration of some ions would be below the level of saturation, and thus these ions would not precipitate. Assuming a dissolved-solids retention of about 5 percent after diversion, dissolved materials accumulated in the lake would total about 6,450 tons per year. During this study, the lake retained 50,000 tons per year, or about 11 percent of the inflowing quantity. Theoretically, the 87 percent reduction in quantity of retained materials would slow the rate of eutrophication by 87 percent, or 1 year at the present rate of enrichment would be equal to about 8 years after diversion.

The balance of dissolved materials (or 122,403 tons per year) would leave the lake by way of the Oneida River (table 29).

Because of interest in nitrogen and phosphorus as plant nutrients, calculations were made to estimate the inflow of the two nutrients after diversion. Total phosphate input would be reduced by about 45 percent, or 
from 2.52 to about 1.38 tons per day. Total nitrogen input would be reduced about 36 percent, or from 2.81 to 1.79 tons per day. It is not possible to estimate what the concentrations of the two nutrients would be in the lake water. The concentrations are influenced by "luxury" consumption of phosphorus by algae, nitrogen-fixation by blue-green algae, and incorporation of the two nutrients into the bottom sediments.

of the diverted phosphate and nitrogen, 0.32 tons per day and 0.30 tons per days, respectively, originated from the population served by sewers in the south basin (table 21). Stream diversion, therefore, not only would reduce total inflow of phosphate and nitrogen to the lake but also would remove the greatest amount of artificial enrichment that the lake is experiencing. After diversion, the only cultural influences on the chemical quality of lake water would come from the lake and the lakeshore population.

The effect of diversion of the south tributaries on the downstream Oneida River would probably be minimal. Assuming that diversion was accomplished to the part of the Oneida River between Brewerton and Caughdenoy Dam, the quantity and the quality of water below the point of diverted water inflow would be virtually the same as it is now.

A mixture of water from south tributaries would have a dissolvedsolids content of $455 \mathrm{mg} / 1$. The combination of that water with lake water (dissolved-solids content about $70 \mathrm{mg} / 1$ ) would have a dissolved-solids content of about $174 \mathrm{mg} / 1$. A slightly higher dissolved-solids content in the downstream Oneida River, after diversion, would result from decreased retention of dissolved materials by the lake. The effect of the slight increase on the dynamics of the Oneida River would be insignificant. 

In the spring of 1967, the U.S. Geological Survey, in cooperation with the New York State Department of Environmental Conservation, began a comprehensive program to study the eutrophication of Oneida Lake. The objectives of the program were to define cause and effect relationships contributing to algal production in the lake and to provide necessary information for controlling the algal blooms.

The approach used during the study was a consideration of how one major environmental factor affected another. Emphasis was placed on the discovery of phenomena that were operationally significant to the physiological processes of the algae and on the determination of how the phenomena affected the algal populations.

This final report of the study describes and discusses the limnology of oneida Lake and its drainage basin. The report emphasizes factors contributing to the annual nuisance algal blooms in the lake. Conclusions based on the study follow:

1. Oneida Lake is a eutrophic lake that has existed for about 10,500 years. The fertile drainage basin of the lake was once the bottom of an inland fresh-water sea, and drainage from the area brings an abundance of soluble minerals and dissolved organic materials into the lake.

2. The drainage basin of the lake can be divided into five hydrochemically distinct and internally homogeneous terranes. They are Tug Hill, Lake Plain, Till, Sand and Gravel, and Salina Group Terranes. All except the Salina Group Terrane have little effect on the hydrochemistry of the streams in the basin.

3. Oneida Lake has become eutrophic through natural events. Geochemically derived dissolved solids entering the lake from the drainage basin support the annual algal blooms.

4. The lake has been eutrophic for at least 350 years. Early settlers observed that the algae in the lake were of the bloom-forming type. The same forms are still evident in Oneida Lake.

5. Oneida Lake drainage basin can be considered primarily rural, because more than 54 percent of the basin is undeveloped and about 35 percent is used for farming. The 91,000 persons in the basin are concentrated in the area south of the lake. The population served by sewers totals about 29,800 .

6. Population of the shoreline of Oneida Lake has increased from about 1,600 persons in 1900 to about 14,100 persons in 1960. In addition to the resident population, more than 1 million sportsmen and water enthusiasts annually visit the area.

7. Water in Oneida Lake, as indicated by stage and (or) volume, represents a dynamic equilibrium of hydrologic conditions. Water entering the lake is from direct precipitation (149,600 acre-feet 
per year) and surface-water inflow $(1,729,000$ acre-feet per year). Ground-water contributions are negligible. Water leaves the lake by outflow through the Oneida River (1,730,400 acre-feet per year) and by evaporation $(148,200$ acre-feet per year).

8. Oneida Lake has a surface area of 79.8 square miles and serves a drainage basin of 1,382 square miles. The lake is 20.9 miles long and 5.5 miles wide. Its maximum depth is 55 feet and its average depth is only 22.3 feet. Flow-through time of the lake is 235 days.

9. Bottom sediments of Oneida Lake can be divided into five types based on composition and size of materials. The types and their percentage distribution are cobble and rubble, 10.2 percent; gravel, 4.2 percent; sand, 17.8 percent; silt and clay, 40.3 percent; and mud (silt, clay, and organic matter), 27.5 percent. Distribution of bottom materials has not changed significantly in the past 60 years.

10. Oneida Lake does not stratify thermally during the summer but does exhibit near-anaerobic conditions in the lower layers of water during the growing season. A sharp dissolved-oxygen stratification at about 30-foot depth accompanies the increase in phytoplankton productivity in the upper layers of water.

11. One of the most influential factors among the processes in the lake is wind-generated wave action. Prevailing westerly winds can create a maximum wave height of about 6 feet on Oneida Lake and effective mixing to a depth of about 30 feet, the same depth as dissolved-oxygen stratification. Sixty-five percent of the lake bottom is shallower than 30 feet and can be subjected to mixing with the overlying water.

12. Seiches are responsible for additional water mixing and for partial horizontal transfer of materials in Oneida Lake. The typical seiche is uninodal and extends the long axis of the lake. Vertical displacement of water may exceed 1.6 feet during a period of about 2.4 hours.

13. Surface currents in the lake are usually in the direction of the prevailing wind, and greatest current velocities are associated with sustained moderate winds of 5-10 miles per hour. Deep-water currents generally flow opposite the direction of the winds.

14. Wind streaks on Oneida Lake are most pronounced during periods of moderate westerly winds, when wave height ranges from 1 to 2 feet. The streaks correspond with the maximum surface currents.

15. Ice cover confines the water of the lake for about 4 months each year, and an ice thickness of 3 feet or more is common during late March.

16. Lake water is displaced by inflowing tributary water under ice cover. Water from each of the tributaries remains more or less as separate water masses. Mixing occurs only after ice breakup. 
17. Secchi disc transparency averages about 5.86 feet. Greatest transparencies occur in the open lake; the 1 -percent penetration depth averages 13.1 feet. This depth represents the lower limit of the euphotic zone in Oneida Lake.

18. Bloom-essential concentrations of nutrients in Oneida Lake reached critical minimal concentrations many years ago and, subsequently, have increased. Concentrations of nutrients in the lake are more than adequate for the healthy existence of phytoplankton, even during large algal blooms.

19. Dissolved nutrients in Oneida Lake are virtually uniform in concentration, both vertically and areally. However, concentrations in the west and the south parts of the lake are slightly higher than in the rest of the lake because of inflow of high-mineralized water from the south tributaries.

20. Quality of the lake water depends on quality of inflowing water. Dissolved-solids content of the lake fluctuates seasonally with changes in the amount of surface-water inflow and annually with changes in the annual water budget.

21. Available data indicate that the chemical quality of Oneida Lake was virtually stable from 1927 through 1969.

22. Of those studied, no element, ion, or compound seems to be a limiting factor on the bodily processes of algae or on the extent of bloom formation in Oneida Lake. Nitrogen and phosphorus did not approach growth-limiting concentrations during the study. The quantity of dissolved solids is probably an index of growth conditions in the lake, because it integrates the total nutritional complex with interactions of environmental factors.

23. The greatest amount of dissolved solids (72 percent) enters oneida Lake through the south tributaries, whereas the greatest amount of water (67 percent) enters through the north ones. Chittenango Creek carries the largest load of almost all major chemical substances and contributes 37 percent of all dissolved solids entering Oneida Lake.

24. Maximum cultural contributions of total nitrogen and total phosphates to the lake were 0.48 and 0.50 tons per day, respectively. The two loads represent about 17 and 20 percent of the total loads, respectively. If the cultural sources of nitrogen and phosphate were eliminated, the quantities entering the lake from natural sources could maintain concentrations above the minima needed to support large algal blooms in Oneida Lake.

25. Dissolved solids entering oneida Lake are from the drainage basin $(449,700$ tons per year) and from direct precipitation (1,800 tons per year). The lake retains 50,000 tons of dissolved solids per year. The balance $(401,500$ tons per year) leaves the lake through the Oneida River. 
26. Because there has been no detectable increase in the nutrient enrichment of the lake water, the rate of eutrophication of Oneida Lake can be considered to have remained virtually unchanged for many years.

27. Observed biological changes in Oneida Lake from 1916 through 1969 are minimal. All changes seem to be steps in the never-ceasing natural process of lake succession.

28. Of the 117 species of algae observed in the phytoplankton, 42 are common or abundant. The four species of blue-green algae that characterize Oneida Lake are Anabaena flos-aquae, Aphanizomenon holsaticum, Microcystis aemiginosa, and Anabaena circinalis.

29. Other abundant blue-green algae in Oneida Lake include Anabaena spiroides, GLoeotrichia echinulata, Microcystis incerta, Lingbya Birgei, and Oscitlatoria subbrevis.

30. Phytoplankton populations usually vary throughout the lake. Heavy concentrations in bay areas and localized blooms are common.

31. Algal production seems to be stimulated near shoal areas and in certain bays. Heavy algal concentrations along the shore and decaying heaps of algae on the shore usually result from wind-swept drifts of algal mats from the open lake.

32. Because most blue-green algae are buoyant, the apparent severity of established algal blooms in Oneida Lake is inversely proportional to wind action.

33. The four most important factors affecting the processes in Oneida Lake are: (1) high fertillty of the drainage basin, (2) physical position and shallowness of the lake, (3) mixing as caused by wind, and (4) fertility of the bottom sediments.

34. Observations during the current study and suggested environmental relationships in past studies indicate that nuisance algal conditions in Oneida Lake are assoclated with years of drought and years in which the contribution of water from the southern streams is greater than usual. The hydrologic regime of oneida Lake and its drainage basin is a principal factor in the production of algae.

35. Reduction in quantity of nutrlents flowing into Oneida Lake would reduce the nutrient content in the lake and would decrease the potential for biological production. The reduction could be accomplished by diversion of the south tributaries around or away from the lake.

36. Diversion of the south tributaries would have little effect on many of the physical processes in the lake. The most pronounced changes would occur in the annual water budget and in the dissolved-solids content. 
37. Enough water to maintain the hydrologic equilibrium of the lake enters Oneida Lake from the north tributaries.

38. Diversion of the south tributaries would probably reduce the average dissolved-solids content of the lake from 163 to about 70 $\mathrm{mg} / 1$.

39. Stream diversion would remove the greatest amount of artificial enrichment that the lake is now receiving.

40. The effect of diversion of the south tributaries on the downstream oneida River would probably be minimal. 



\section{GLOSSARY}

AEROBIC: requiring oxygen; oxygenated; having oxygen.

ALGAE: the group of simple or primitive plants that generally are microscopic in size and live in wet or damp places.

ALGAL BLOOM: the relatively rapid increase in the total number of phytoplankton per unit time to the extent that their presence hinders the utility of a body of water.

ALLOCHTHONOUS: produced outside (of a lake) and transported in.

ANAEROBIC: devoid of oxygen.

ARTIFICIAL ENRICHMENT: the addition to a body of water of nutritive materials derived from cultural activities.

AUGMENTATION: supplementation.

AUTOCHTHONOUS: produced within (a lake).

BENTHIC ALGAE: algae that grow in or on the bottom of a body of water.

BENTHIC FAUNA: animal organisms that live in or on the bottom of a body of water.

BENTHIC FLORA: plant organisms that live in or on the bottom of a body of water.

BENTHOS: organisms that live in or on the bottom of a body of water.

BIOLOGICAL GRAZERS: animal organisms that feed on vegetation; herbivores.

BLOOM: (see ALGAL BLOOM).

BLUE-GREEN ALGAE: algae (Division Cyanophyta) that lack chloroplasts and have pigments dispersed through the entire protoplast.

CELERITY (of waves): the speed of movement.

CHAROPHYTIC: of or pertaining to the class of green algae containing charophytes (that is, Chara, Nitezza, and Tolypezza).

CHEMICAL CYCLE: the circular path of an element in its various combinations from the environment to the organism and back to the environment.

CHEMICAL REDUCTION: the addition of hydrogen to or the substraction of oxygen from a substance; a reaction opposite to the chemical oxidation.

COL: a gap across or depression in a ridge.

CUESTA-FORM TOPOGRAPHY: a sloping plain that is abrupted on one side by a steep slope. 
DEPTH: the vertical distance between the surface and the bottom.

DEVELOPMENT OF SHORELINE: the uniformity index of the shoreline. The index of 1 represents a circle.

DEVELOPMENT OF VOLUME: the uniformity index of volume. The index of 1 represents a cone.

DIATOMACEOUS MATERIALS: a conglomerate consisting primarily of diatom frustules.

DIATOMS: a group of algae, Division Chrysophyta, characterized by a cell wall of pectic materials impregnated with silica, which gives it a glass-like appearance and texture.

DINOFLAGELLATE: an organism having two flagella.

DISCHARGE: the volume of water (or total fluids) that passes a given point within a given period of time.

DRAINAGE AREA: land and water surfaces from which a lake derives its inflow of water.

DRAINAGE BASIN: (sEe DRAINAGE AREA).

DRUMLIN: an elongated, glacially-deposited hill of gravel.

ECOLOGICAL SUCCESSION: the gradual progression from one life stage into another.

ENRICHMENT: addition or accumulation of nutrients within a body of water.

EPILIMNION: the upper layer of water during periods of thermal stratification in a lake.

ESCARPMENT: a steep slope abruptly terminating a high plain.

ESSENTIAL ELEMENT: any element that in some chemical form is required for the nutrition of an organism.

EUPHOTIC ZONE: the lighted region of a lake.

EUTROPHICATION: the natural process of aging of a body of water through ecological succession and enrichment.

EUTROPHIC LAKE: a lake having an abundant amount of dissolved nutrients.

EVAPORATION: the conversion of water from the liquid to the vapor state at a temperature lower than the boiling point.

EVAPOTRANSPIRATION: the sum total of evaporation and transpiration.

FAUNA: animal organisms. 
FETCH: the uninterrupted, straight-line distance from the shore to the point of interest, usually associated with wave formation.

FILAMENTOUS ALGAE: threadlike forms of algae having a linear arrangement of cells. These forms are generally macroscopic and benthic.

FLORA: plant organisms.

FLOW-THROUGH TIME: the time necessary for the volume of a lake to be replaced by inflowing water, assuming that there is a complete mixing of the lake water.

FRUSTULES: the siliceous, or "glass-like" shells of diatoms.

GEOCHEMISTRY: the science of the chemical characteristics of the earth.

GREEN ALGAE: algae (Division Chlorophyta) that contain chloroplast in which chlorophyll is predominant.

GROUND WATER: the water beneath the surface of the ground.

HIGHER PLANT: (sEe VASCULAR PLANTS).

HOMOTHERMOUS: uniform or equal in temperature.

HYDROCHEMISTRY: the science or study of the chemistry of water.

HYDROGRAPHIC MAP: a chart of the lake bottom indicating various depth contours.

HYDROLOGY: the earth science that relates to the occurrence of water in the earth, its physical and chemical reactions with the rest of the earth, and its relation to living organisms.

HYPOLIMNION: the bottom layer of water during period of thermal stratification in a lake.

ISOHYETAL MAP: a map that shows the distribution of precipitation by lines connecting points of equal precipitation.

LENGTH: the long axis of a lake.

LENGTH OF SHORELINE: the linear distance of the lake shore.

LIMITING FACTOR: any substance or condition that approaches or exceeds the upper or lower tolerance limits of an organism.

LIMNOLOGY: the science of fresh water, especially of ponds and lakes, including physical, chemical, and biological conditions.

LONG AXIS: the greatest length of a lake.

MACROBENTHOS: large, nonmicroscopic organisms that live in or on the bottom of a body of water. 
MACROMETABOLITE: a nutrient that is required in relatively large quantities. MACRONUTRIENT: (sEe MACROMETABOLITE).

MACROPHYTES: (sEe VASCULAR PLANTS).

MACROSCOPIC: visible to the unaided eye.

MARL: calcareous deposits; calcium carbonate.

MESOTROPHIC LAKE: a lake with a moderate content of dissolved nutrients.

MICROMETABOLITE: a nutrient that is required in relative small or trace quantities.

MICRONUTRIENTS: (sEe MICROMETABOLITE).

MUCILAGE: the gelatinous sheath enveloping most colonial species of bluegreen algae.

MUCKLAND: commonly a wet area having dark-colored soil that has a high percentage of decomposing or finely pulverized organic matter such as peat.

MUD: a mixture of silt, clay, or organic matter having an appearance of black ooze.

NITROGEN FIXATION: the ability of certain bacteria and blue-green algae to utilize atmospheric or dissolved gaseous nitrogen in their physiological processes.

NODAL POINT: the point in an oscillating medium at which the amplitude is reduced to zero; the point of rotation of an oscillation; (see SEICHE).

NUTRIENT: any substance that is required by an organism for the continuation of growth, for repair of tissue, or for reproduction.

OLIGOTROPHIC LAKE: a lake with a low content of dissolved nutrients.

ORGANISM: a living plant or animal.

PERIPHYTON: the miscellaneous assemblage of organisms living upon the free surfaces of objects submerged in water.

PHOTOSYNTHESIS: the utilization of light as an energy source for the conversion of inorganic solutes to living matter by chlorophyll-bearing organisms.

PHOTOSYNTHETIC ZONE: (sEE EUPHOTIC ZONE).

PHYSIOGRAPHIC: of or pertaining to the genesis and evolution of land forms. PHYTOPLANKTON: plant organisms of the plankton. 
PLANKTON: passively floating or weakly swimming aquatic organisms of relatively small size that are at the mercy of the water currents.

PLANT TRANSPIRATION: (sEe TRANSPIRATION).

PREVAILING WINDS: average or normai winds.

PRIMARY PRODUCERS: plant organisms that utilize dissolved nutrients directly from the water.

PRODUCTIVITY: total amount of organic matter that is formed from raw materials.

RETENTION TIME: (sEe FLOW-THROUGH TIME).

SEDIMENTATION: deposition of suspended or dissolved materials on the bottom of a lake or stream.

SEDIMENTS: mineral or organic solid materials carried in suspension or settled from suspension in a liquid.

SEICHE: oscillation of water about one or more nodal points within a lake. It is a localized and periodic shift of the water level in which the water particles advance and return in the same path.

SEICHE AMPLITUDE: vertical extent of water displacement during a seiche.

SESTON: total heterogeneous mixture of living and non-living materials suspended in water.

SHOAL: (sEe SHOAL AREA).

SHOAL AREA: the part of the lake that is shallower than 14 feet in depth.

SHORELINE: the margin of land surrounding the lake surface.

SOLAR RADIATION: light received directly from the sun.

SPATIAL: of or in space; areal.

STAGE: elevation of the surface of a body of water.

STANDING CROP: total quantity of living material at any moment in time.

STANDING WAVE: (see SEICHE).

STREAM DIVERSION: act of taking water from the natural stream channel and introducing it into a canal or other conduit.

SUMMER STAGNATION PERIOD: period of thermal stratification in a lake when the hypolimnion is anaerobic.

SURFACE AREA: the expanse of the lake surface. 
SURFACE WATER: water that flows over or rests upon the surface of the ground.

SURFICIAL GEOLOGY: characteristics of the earth's uppermost layers.

TEMPORAL: of or in time.

TERRANE: a complex group of strata accumulated within a definite geologic epoch.

THERMAL RESISTANCE: the resistance to mixing because of thermally produced density differences between the upper and the lower layers of water.

THERMAL STRATIFICATION: distinct layering of a body of water because of thermal differences.

THERHOCLINE: the layer of water between the epilimnion and the hypolimnion where the temperature rapidly declines per unit depth from the upper margin to the lower margin.

TRACE ELEMENT: an element that exists in very minute quantities in the environment.

TRANSPIRATION: the process by which water vapor is transferred to the atmosphere from a living plant.

TRIBUTARY: any stream that contributes water to another stream or body of water.

TYCHOPLANKTON: planktonic organisms that originated from attached communities.

VACUOLIZED: containing vacuoles or "air pockets."

VASCULAR PLANT: highly developed plants with a water conducting system. Generally, those plants with leaves, stems, and roots.

VERNAL: of or in the spring.

VERNAL PULSE: increase in standing crop of plankton during the spring season.

VOLUME: amount of water in lake.

WATER COLUMN: vertical profile in a lake from surface to bottom.

WATERSHED: (sEe DRAINAGE AREA).

WAVE AMPLITUDE: one-haif of the wave height.

WAVE HEIGHT: maximum vertical distance between crest and trough of a wave.

WAVE LENGTH: linear distance from crest to crest or from trough to trough between successive waves. 
WAVE OF OSCILLATION: vertical rise and fall of the water at successive positions in which the water particles move in a circular path.

WIDTH: the short axis of a lake.

WIND ROSE: a diagrammatic representation of wind directions at a given location.

WIND VELOCITY: speed of the wind.

ZOOPLANKTON: animal organisms of the plankton. 



\section{REFERENCES}

Adams, C. C., 1928a, General description of Oneida Lake: Roosevelt Wild Life Annals, v. 1, p. 247-253.

1928b, The economics and'social value of Oneida Lake fish:

Roosevelt Wild Life Annals, v. 1, p. 254-260.

Adams, C. C., and Hankinson, T. L., 1916, Notes on Oneida Lake fish and fisheries: Trans. Am. Fisheries Soc., v. 45, p. 154-169.

1928a, Annotated list of Oneida Lake fish: Roosevelt Wild Life Annals, v. 1, p. 283-521.

1928b, The ecology and economics of Oneida Lake fish: Roosevelt Wild Life Annais, v. 1, p. 239-548.

Allen, M. B., and Arnon, D. 1., 1955, Studies on nitrogen-fixing blue-green algae. 1. Growth and nitrogen fixation by Anabaena cyzindrica Lemm.: Plant Physiology, v. 30, p. 366-372.

American Public Health Association, American Water Works Association, and Water Pollution Control Federation, 1965, Standard methods for the examination of water and wastewater including bottom sediments and sludges (H. P. Orland, ed., 12th ed.): New York Am. Public Health Assoc., 769 p.

American Water Works Association, 1967, Sources of nitrogen and phosphorus in water supplies: Am. Water Works Assoc. Jour., v. 59, p. 344-366.

Baker, F. C., 1916a, Description of a new variety of Lampsilis from Oneida Lake with notes on the L. Zuteola group: Nautilus, v. 30, p. 74-77.

1916b, The freshwater mollusca of Oneida Lake, New York: Nautilus, v. $30, p \cdot 5-9$.

$1916 \mathrm{c}$, The relation of mollusks to fish in Oneida Lake, New York: New York State Coll. Forestry Technology. Pub. no. 4, $366 \mathrm{p}$.

1918, The productivity of invertebrate fish food on the bottom of Oneida Lake, with special reference to mollusks: New York State Coll. Forestry Technology. Pub. no. 9, 264 p.

Benoit, R. J., and Curry, J. J., 1961, Algae blooms in Lake Zoar, Connecticut, in Algae and Metropolitan Wastes. USPHS Tech. Rept. W61-3, p. 18-22.

Biggar, H. P., 1929, The works of Samuel de Champlain: Toronto, The Champlain Soc., v. 3, $418 \mathrm{p}$.

Birge, E. A., and Juday, C., 1922, The inland lakes of Wisconsin. The plankton - I. Its quantity and chemical composition: Wisc. Geol. and Nat. History Survey Bull., v. 64, p. 1-222. 
Bortels, H., 1940, Uber die Bedeutung des Molybbäns für stickstoffbindendene Nostocaceen: Arch. Mikrobiol., v. 11, p. 155-186.

Broughton, J.G., Fisher, D. W., Isachsen, Y.W., and Rickard, L. V., 1962, The Geology of New York State: New York State Mus. and Sci. Service, Geol. Survey, Map and Chart Ser. no. 5 (Text), $42 \mathrm{p}$.

Buddhari, W., 1960, Cobalt as an essential element for blue-green algae: Ph. D. thesis, Berkeley, Univ. of Calif., $163 \mathrm{p}$.

Burdick, G. E., and Lipschuetz, M., 1946, A report on the investigation of Oneida Lake: New York State Conserv. Dept., mimeo, 23 p.

Carroll, D., 1962, Rainwater as a chemical agent of geólogical processes -a review: U.S. Geol. Survey Water-Supply Paper 1535-G, $18 \mathrm{p}$.

Chu, S. P., 1943, The influence of the mineral composition of the medium on the growth of planktonic algae. 11 . The influence of the concentrations of inorganic nitrogen and phosphate phosphorus: Jour. Ecology, v. 31, p. $109-148$.

Cialdi, A., 1866, Sul moto ondoso del mare (2d ed.): Roma, v. 28, 693 p. (after Hutchinson, 1957).

Cobb, H. D., and Meyers, J., 1964, Comparative studies of nitrogen fixation and photosynthesis in Anabaena cylindrica: Am. Jour. Botany, v. 51, p. 753-762.

Dapples, E. C., 1959, Basic geology for science and engineering: New York, John Wiley and Sons, 609 p.

Dence, W. A., and Jackson, D. F., 1959, Changing chemical and biological conditions in Oneida Lake, New York: School Sci. and Math., v. 59, p. 317-324.

Edmondson, W. T., 1970, Phosphorus, nitrogen, and algae in Lake Washington after diversion of sewage: Science, v. 169, p. 690-691.

Edmondson, W. T., Anderson, G. C., and Peterson, D. R., 1956, Artificial eutrophication of Lake Washington: Limnology and Oceanography, $v .1$, p. 47-53.

Eyster, C., 1965, Micronutrient requirements for green plants, especially algae, in Algae and Man (D. F. Jackson, ed.): Syracuse, Syracuse Univ. Press, p. 86-119.

Federal Water Pollution Control Administration, 1966, Fertilization and algae, in Lake Sebasticook, Maine: Cincinnati, Robt. A. Taft Sanitary Eng. Center, $124 \mathrm{p}$.

1968, Water pollution problems and improvement needs, Lake Ontario and St. Lawrence River basins: Chicago, Federal Water Pollution Control Administration, $125 \mathrm{p}$. 
Flory, R. D., 1956, Report on a study of the flora at the Cornell Biological Field Station (Shackelton Point Estate): Cornell Univ. Biol. Field Sta., unpub., $115 \mathrm{p}$.

Fogg, G. E., 1966, Algal cultures and phytoplankton ecology: Madison, Univ. Wisc. Press, $126 \mathrm{p}$.

Forel, F. A., 1895, Lë Leman: Lausanne, Monographie limnologique, v. 2, $651 \mathrm{p}$.

Forney, J.L., 1961a, Growth, movement, and survival of smallmouth bass Microptems doZomieui in Oneida Lake, New York: New York Fish and Game Jour., v. 8, p. 88-105.

196 lb, Year-class distribution of walleyes collected by five types of gear: Am. Fisheries Soc. Trans., v. 90, p. 308-311.

1963, Distribution and movement of marked walleyes in Oneida Lake, New York: Am. Fisheries Soc. Trans., v. 92, p. 47-52.

1964a, Evaluation of pulsed direct current for collecting fish in Oneida Lake: Rept. of Proj. no. F-17-R-8, job no. I-c, Cornell Univ. Biol. Field Sta., mimeo, 2 p.

1964b, Marking of walleyes and smallmouth bass; routine sampling of Oneida Lake fish populations: Rept. of Proj. no. F-17-R-8, job no. 1-a, Cornell Univ. Biol. Field Sta., mimeo, 9 p.

1964c, Utility of a small spawning impoundment for increasing northern pike production: Rept. of Proj. no. F-17-R-8, job no. I1-a, Cornell Univ. Biol. Field Sta., mimeo, $1 \mathrm{p}$.

1965a, Factors affecting growth and maturity in a walleye population: New York Fish and Game Jour., v. 12, p. 217-232.

1965b, Marking of walleyes and smallmouth bass; routine sampling of Oneida Lake fish populations: Rept. of Proj. no. F-17-R-9, job no. 1-a, Cornell Univ. Biol. Field Sta., mimeo, $24 \mathrm{p}$.

1965c, Utility of a small spawning impoundment for increasing northern pike production: Rept. of Proj. no. F-17-R-9, job no. 11-a, Cornell Univ. Biol. Field Sta., mimeo, $7 \mathrm{p}$.

1966a, Factors affecting first-year growth of walleyes in Oneida Lake, New York: New York Fish and Game Jour., v. 13, p. 146-167.

1966b, Marking of walleyes and smallmouth bass; routine sampling of Oneida Lake fish populations: Rept. of Proj. no. F-17-R-10, job no. 1-a, Cornell Univ. Biol. Field Sta., mimeo, 34 p.

1966c, Study of conditions influencing year-class strength of walleyes in Oneida Lake: Rept. of Proj. no. F-17-R-10, job no. 1-b, Cornell Univ. Biol. Field Sta., mimeo, $23 \mathrm{p}$. 
1966d, Utility of a small spawning impoundment for increasing northern pike production: Rept. of Proj. no. F-17-R-10, job no. II-a, Cornell Univ. Biol. Field Sta., mimeo, 5 p.

Forney, J.L., and Houde, E. D., 1964, Study of conditions influencing yearclass strength of walleyes in Oneida Lake: Rept. of Proj. no. F-17-R8, job no. 1-b, Cornell Univ. Biol. Field Sta., mimeo, 29 p.

1965, Study of conditions influencing year-class strength of walleyes in Oneida Lake: Rept. of Proj. no. F-17-R-9, job no. I-b, Cornell Univ. Biol. Field Sta., mimeo, 13 p.

Forney, J.L., and Taylor, C. B., 1963, Age and growth of white bass in Oneida Lake, New York: New York Fish and Game Jour., v. 10, p. 194200.

Fruh, E. G., 1967, The overall picture of eutrophication: Jour. Water Pollution Control Federation, v. 39, p. 1449-1463.

Gerloff, G. C., and Skogg, F., 1954, Cell content of nitrogen and phosphorus as a measure of their avallability for growth of Microcystis aeruginosa: Ecology, $v .35, p .348-353$.

1957, Nitrogen as a limiting factor for the growth of Microcystis aemuinosa in southern Wisconsin lakes: Ecology, v. 38, p. 556-561.

Greeson, P. E., 1969, Lake eutrophication. A natural process: Water Resources Bull., v. 5, p. 16-30.

Greeson, P. E., and Meyers, G. 5., 1969, The limnology of Oneida Lake. An interim report: New York State Water Resources Comm. Rept. of Inv. RI $-8,64 \mathrm{p}$.

Gross, M. G., 1967, Oceanography: Columbus, Charles E. Merrill Books, $297 p$.

Grosslein, M. D., 1961, Estimation of angler harvest on Oneida Lake, New York: Ph. D. thesis, Ithaca, Cornell Univ., 169 p.

Hal1, D. J., 1967, Limnology of Oneida Lake: Prog. Rept. Hatch 479, Cornell Univ. Biol. Field Sta., mimeo, 8 p.

Hankinson, T. L., 1928a, Breeding habits of Oneida Lake fishes: Roosevelt Wild Life Annals, v. 1, p. 260-270.

1928b, Identification of Oneida Lake fishes: Roosevelt Wild Life Annals, v. I, p. 240-283.

Harmon, W. N., and Forney, J.L., 1970, Fifty years of change in the molluscan fauna of Oneida Lake, New York: Limnology and Oceanography, v. 15, p. 454-460.

Hasler, A. D., 1947, Eutrophication of lakes by domestic drainage: Ecology, v. 28, p. 383-395. 
Houde, E. D., 1968, The relation of water current and zooplankton abundance to distribution of larval walleyes Stizostedion vitreum vitreum, in Oneida Lake, New York: Ph. D. thesis, Ithaca, Cornell Univ., 164 p.

Hough, J. L., 1958, Geology of the Great Lakes: Urbana, Univ. 111. Press, $313 \mathrm{p}$.

House, H. D., 1918, The vegetation of the eastern end of Oneida Lake: New York State Mus. Bull. 197, p. 61-110.

Hunt, 0. P., 1963, Use of low-flow measurements to estimate flow duration curves: U.S. Geol. Survey Prof. Paper 475-C, p. 196-197.

Hutchinson, G. E., 1957, A treatise of 1 imnology. Geography, physics, and chemistry: New York, John Wiley and Sons, v. 1, 1015 p.

Jackson, M. L., 1964, Soil chemical analysis: Englewood Cliffs, PrenticeHall, $498 \mathrm{p}$.

Jacobsen, T. V., 1966, Trends in abundance of the mayfly (Hexagenia limbata) and chironomids in Oneida Lake: New York Fish and Game Jour., v. 13, p. $168-175$.

Jenkins, David, 1968, The differentiation, analysis, and preservation of nitrogen and phosphorus forms in natural waters: Washington, Am. Chem. Soc., Advances in Chem. Ser. 73, p. 265-280.

Juday, C., and Birge, E. A., 1933, The transparency, the color, and the specific conductance of the lake waters of northeastern wisconsin: Wisc. Acad. Arts \& Letters Trans., v. 28, p. 205-259.

Kantrowitz, 1. H., 1970, Ground-water resources in the eastern Oswego River basin: New York State Water Resources Comm. Basin Planning Rept. ORB-2, $130 \mathrm{p}$.

Karas, Nicholas, 1967, Oneida...fishiest lake of them all: Field and stream, v. 72, p. 98-105.

Karrow, P. F., Clarke, J.P., and Terasmae, J., 1961, The age of Lake Iroquois and Lake Ontario: Jour. Geology, v. 69, p. 659-667.

Kratz, W. A., and Myers, J., 1955, Nutrition and growth of several bluegreen algae: Am. Jour. Botany, v. 42, p. 282-287.

Krauss, R. W., 1956, Photosynthesis in the algae: Ind. and Eng. Chemistry, v. $48, p \cdot 1449-1458$.

Kuentzel, L. E., 1969, Bacteria, carbon dioxide, and algal blooms: Jour. Water Pollution Control Federation, v. 1969, p. 1737-1747.

Landgraff, H.C., 1911, Oneida Lake - past and present: Albany, New York State Libr., 20 p. 
Langmuir, Irving, 1938, Surface motion of water induced by wind: Science, v. 87, p. 119-123.

Larkin, P. A., and Northcote, T. G., 1958, Factors in lake topography in British Columbia, Canada: Verh. int. Ver. Theor., angew, Limnology, v. 13, p. 252-263.

Leutz, W. P., 1964, The Salina Group, in New York State Geological Association Guidebook: 36th Ann. Meeting of New York State Geol. Assoc., p. $57-65$.

Leverett, F., and Taylor, F. B., 1915, The Pleistocene of Indiana and Michigan and the history of the Great Lakes: U.S. Geol. Survey Mon. $53,529 \mathrm{p}$.

Leven, G. V., 1960, Sodium chloride uptake by algae: Public Waters, V. 91 , p. 7 and 95.

Lund, J.W. G., 1950, Studies on Astemionelza formosa Hass. 11. Nutrient depletion and the spring maximum: Jour. Ecology, v. 38, p. 1-35.

1954, The seasonal cycle of the plankton diatom, Melosira italica (Ehr.) Kutz, subsp. subartica 0. Mull.: Jour. Ecology, v. 42, p. $151-179$.

Macclintock, Paul, and Terasmae, Jaan, 1960, Glacial history of Covey Hill: Jour. Geology, v. 68, p. 232-241.

Mackenthun, K. M., Lowell, E. K., and Stewart, R. K., 1968, Nutrients and algae in Lake Sebasticook, Maine: Jour. Water Pollution Control Federation, v. 1968, p. 72-81.

Mahin, E. G., and Carr, R. H., 1923, Quantitative agricultural analysis: New York, McGraw-Hill, 329 p.

Meyer, B. S., Anderson, D. B., and Böhning, R. H., 1964, Introduction to plant physiology: Princeton, D. Van Nostrand Co., $541 \mathrm{p}$.

Miller, W. E., and Tash, J. C., 1967, Interim report- Upper Klamath Lake studies: Fed. Water Pollution Control Adm. Pub. no. WP-20-8, 37 p.

Mozley, Alan, 1954, An introduction to molluscan ecology: London, H. K. Lewis Pub., 71 p.

Mt. Pleasant, R. C., Rand, M. C., and Nemerow, N. L., 1961, Chemical and microbiological aspects of Oneida Lake, New York: New York State Dept. of Health, Research Rept. no. 8, 95 p.

Muenscher, W. C., 1928, Plankton studies of Cayuga, Seneca, and Oneida Lakes, in A biological survey of the Oswego River system, Suppl. to 17th Ann. Rept., 1927: New York State Conservation Dept., p. 140-157.

Muller, E. H., 1965, Quaternary geology of New York, in Wright, H. E., and Frey, D. G., eds., Quaternary of the United States: Princeton, Princeton Univ. Press, p. 99-112. 
Nall, R. W., 1965, Some factors affecting phytoplankton pulses in the ohio River at Louisville, Kentucky: Ph. D. thesis, Louisville, Univ. of Louisville, $138 \mathrm{p}$.

New York State Board of Health, 1888, Annual report of the New York State Board of Health: Albany, N.Y., p. 194-202 and 233-235.

New York State Conservation Department, 1927, A biological survey of the Oswego River system: Ann. Rept. of the New York State Conserv. Dept., $248 \mathrm{p}$.

1947, Oneida Lake: Conservationist, v. I, p. 8-11.

New York State Department of Health, 1957, Oneida River drainage area: New York State Dept. Health, Oswego River Drainage Basin Survey Rept. no. $5,173 \mathrm{p}$.

Noble, R. L., 1968, Effect of limnological changes on survival of young fish in Oneida Lake: Rept. of Proj. no. F-17-R-12, job no. 1-e, Cornell Univ. Biol. Field Sta., mimeo., 5 p.

1969, Effect of limnological changes on survival of young fish in Oneida Lake: Rept. of Proj. no. F-17-R-13, job no. I-e, Cornell Univ. Biol. Field Sta., mimeo, $10 \mathrm{p}$.

01son, F.C.W., 1951, A plastic envelope substituted for drift bottles: Jour. Marine Research, v. 10, p. 190-193.

Palmer, C. M., 1967, Environmental needs of nuisance algal forms: Albany, N.Y., 4th Ann. Water Quality Symposium Proc., p. 8-35.

Pearsall, W. H., 1932, Phytoplankton in the English lakes. 2. The composition of the phytoplankton in relation to dissolved substances: Jour. Ecology, v. 20,p. 241-262.

Pearson, F. J., Jr., and Meyers, G. S., Hydrochemistry of the Oneida Lake basin: New York State Dept. Environmental Conserv. Rept. of Inv. RI12 (in press), $56 \mathrm{p}$.

Perl, G., 1935, Zur Kenntnis der wahren Sonnenstrahlung in verschiedenen geographischen Breiten: Met. Zeitschr., v. 52, p. 85-89.

Phillips, K. N., Newcomb, R. C., Swenson, H. A., and Laird, L. B., 1965, Water for Oregon: U.S. Geol. Survey Water-Supply Paper 1649, 150 p.

Pilsbry, H. A., 1917, Amnicolidae from Oneida Lake, New York: Nautilus, v. 31, P. $44-46$.

Pirson, A., 1937, Ernahrungs- und Stoffwechselphysiologische Untersuchungen an Fontinalis and ChZorelza Z.: Botan., v. 31, p. 193-267.

Pratt, H. S., 1923, Preliminary report on the parasitic worms of Oneida Lake, New York: Roosevelt Wild Life Bull., v. 23, p. 55-71. 
Table 31.- - Field measurements and chenical analyses of surface samples collected routinely from stations on aneida Lake

(Except for ph, values represent milligrams per liter unless otherwise indicated)

\begin{tabular}{|c|c|c|c|c|c|c|c|c|c|c|c|c|c|c|c|c|c|c|c|c|c|c|c|c|}
\hline Date & Time & $\mathrm{pH}$ & $\begin{array}{l}\text { Dis- } \\
\text { solved } \\
\text { oxygen }\end{array}$ & $\begin{array}{c}\text { Dis- } \\
\text { solved } \\
\text { oxyen } \\
\text { (percent } \\
\text { satu- } \\
\text { ration) }\end{array}$ & $\begin{array}{c}\text { Specific } \\
\text { conduct- } \\
\text { ance } \\
\langle\text { whos } / \mathrm{cm} \\
a t \\
\left.25^{\circ} \mathrm{C}\right\rangle\end{array}$ & $\begin{array}{l}\text { Temper- } \\
\text { ature } \\
\left({ }^{\circ} \mathrm{C}\right)\end{array}$ & $\begin{array}{l}\text { Silica } \\
\left(\mathrm{SiO}_{2}\right)\end{array}$ & $\begin{array}{l}\text { Cai- } \\
\text { cium } \\
\text { (ca) }\end{array}$ & $\begin{array}{l}\text { Magne- } \\
\text { siumg } \\
\text { (Mg) }\end{array}$ & $\begin{array}{l}\text { Stron- } \\
\text { tium } \\
\left\langle\left(S_{r}\right\rangle\right.\end{array}$ & $\begin{array}{c}\text { Sodium } \\
(\mathrm{Na})\end{array}$ & $\begin{array}{l}\text { Potas- } \\
\text { sium } \\
\text { (K) }\end{array}$ & $\begin{array}{l}\text { Bicar- } \\
\text { banate } \\
\left(\mathrm{HCO}_{3}\right)\end{array}$ & $\begin{array}{l}\text { Sul- } \\
\text { fate } \\
\left(\mathrm{SO}_{4}\right)\end{array}$ & $\begin{array}{l}\text { Chlo- } \\
\text { ride } \\
\text { (ci) }\end{array}$ & $\begin{array}{l}\text { Fluo- } \\
\text { ride } \\
\text { (F) }\end{array}$ & $\begin{array}{l}\mathrm{Ni-} \\
\text { trate } \\
\left(\mathrm{NO}_{3}\right)\end{array}$ & $\underset{\substack{\mathrm{Ni-} \\
\text { trite } \\
\left(\mathrm{NO}_{2}\right)}}{\operatorname{lol}}$ & $\begin{array}{l}\text { Ammo- } \\
\text { nium } \\
\left(\mathrm{NH}_{4}\right)\end{array}$ & $\begin{array}{l}\text { Organic } \\
\text { nittro- } \\
\text { gen } \\
(N)\end{array}$ & $\begin{array}{l}\text { Total } \\
\text { nitro- } \\
\text { gen } \\
(N)\end{array}$ & $\begin{array}{l}\text { Total } \\
\text { phos- } \\
\text { phate } \\
\text { (Po }\end{array}$ & $\begin{array}{l}\text { ois- } \\
\text { solved } \\
\text { solids } \\
(\text { residue } \\
\text { ot } \\
\left.180^{\circ} \mathrm{C}\right)\end{array}$ & $\begin{array}{l}\text { Phyto- } \\
\text { plankton } \\
\text { (cells/mi) }\end{array}$ \\
\hline
\end{tabular}

\begin{tabular}{|c|c|c|c|c|c|c|c|c|c|c|c|c|c|c|c|c|c|c|c|c|c|c|c|c|}
\hline & & .- & -. & & & & & & & DN & & SAMPEIN & TATIO & No. 8 & -- & & & -3 & $\ldots$ & $-\mathrm{s}$ & $\ldots$ & & & 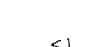 \\
\hline $6-6-67$ & 1430 & 8.3 & 9.90 & 105.6 & 290 & 18.2 & 0.2 & 42 & 9.4 & $\ldots$ & 5.5 & 0.9 & 107 & 57 & $10^{\circ}$ & 0.2 & 0.2 & 0.01 & 0.17 & -. & $\therefore$ & 0.06 & 179 & $<1$ \\
\hline $6-13-67$ & 1240 & -- & 8.16 & 98.4 & 290 & 24.8 & - & & - & -- & $\cdots$ & & & & & & & & & -. & -- & & & 30 \\
\hline $\begin{array}{l}6-20-67 \\
6-27-67\end{array}$ & $\begin{array}{l}2025 \\
0930\end{array}$ & $\begin{array}{r}7.7 \\
-2\end{array}$ & $\begin{array}{l}7.20 \\
8.85\end{array}$ & $\begin{array}{r}79.0 \\
100.9\end{array}$ & $\begin{array}{l}290 \\
285\end{array}$ & $\begin{array}{l}19.6 \\
21.6\end{array}$ & $\begin{array}{l}1.6 \\
-.\end{array}$ & 42. & 9.9 & $\therefore$ & 5.3 & $\begin{array}{l}.8 \\
--\end{array}$ & $\frac{104}{--}$ & 57 & $\begin{array}{l}9.1 \\
\cdots\end{array}$ & .2 & $\therefore$ & .02 & .09 & $=$ & $=$ & .03 & 177 & $\& 1$ \\
\hline $7-6-67$ & 1315 & -- & 9.11 & 104.6 & 300 & 22.0 & 1.8 & 41 & 9.3 & -- & 5.2 & 1.0 & 104 & 55 & 9.0 & .1 & .1 & .00 & .12 & -. & -. & .04 & 174 & $5,700+$ \\
\hline $\begin{array}{l}7-10-67 \\
7-14-67\end{array}$ & $\begin{array}{l}1135 \\
1100\end{array}$ & 8.3 & $\begin{array}{r}10.08 \\
8.50\end{array}$ & $\begin{array}{r}12.4 \\
99.5\end{array}$ & $3 \ddot{10}$ & $\begin{array}{l}25.6 \\
23.1\end{array}$ & 1.8 & $40^{\prime \prime}$ & 9.2 & $=$ & 5.0 & .9 & 102 & 54 & 9.2 & .0 & 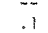 & .00 & 12 & -- & $\because$ & .07 & 170 & $\begin{array}{l}10,700+ \\
9800+\end{array}$ \\
\hline $7-18-67$ & $\begin{array}{l}1415 \\
1815\end{array}$ & $\cdots$ & $\begin{array}{r}9.66 \\
10.00\end{array}$ & $\begin{array}{l}116.4 \\
123.3\end{array}$ & 300 & $\begin{array}{l}24.8 \\
26.0\end{array}$ & $2 \sqrt{4}$ & 39 & & $\because-$ & 5.3. & 9 & & 56 & 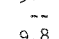 & $\cdots$ & $\because$ & $\therefore$ & $\cdots$ & -. & $\therefore$ & $\cdots$ & 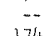 & $7,100+$ \\
\hline $8 \times 1-67$ & 1040 & $\ldots$ & 8.41 & 99.2 & $\ldots$ & 236 & $\ldots$ & $\ldots$ & $\ldots$ & $-\mathrm{H}_{2}$ & $\ldots$ & & & & & & & & & & 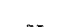 & & & \\
\hline $8-17067$ & 1250 & 8.9 & $\begin{array}{l}0.48 \\
9.75\end{array}$ & 197.8 & 320 & 24.9 & .. & 43 & $\ldots$ & $\ldots$ & $\ldots$ & $\ldots$ & 95 & .. & $=$ & .1 & .1 & .00 & .00 & 0.19 & 0.21 & .06 & $\ldots$ & $\ddot{\ldots}$ \\
\hline $8-22-67$ & 0945 & 8.6 & 8.39 & 98.4 & 310 & 23.2 & $\cdots$ & 43 & -- & - & $\cdots$ & -- & 108 & -. & - & .0 & .0 & .00 & .00 & .09 & .09 & .26 & $\ldots$ & $94,400+$ \\
\hline $3-27-57$ & 1350 & $\cdots$ & 10.80 & $\begin{array}{l}113.6 \\
105.8\end{array}$ & $\approx$ & $\begin{array}{l}17.5 \\
15.6\end{array}$ & $\ldots$ & $\ldots$ & $\ldots$ & 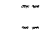 & $\ldots$ & $\ldots$ & $\overline{-\ldots}$ & $\therefore$ & $\ldots$ & $\because$ & $\therefore$ & $\ldots$ & 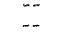 & $\cdots$ & $\therefore$ & $\ldots$ & $\cdots$ & $\therefore$ \\
\hline $5=3-68$ & 1030 & 8.2 & 12.10 & 111.0 & 225 & 11.1 & 4 & 41 & 8.5 & 0.56 & 4.4 & 1.1 & 102 & 50 & 9.7 & .2 & .1 & .03 & .04 & .19 & .25 & .14 & 166 & 1,500 \\
\hline $8-20-68$ & 0830 & 8.2 & 8.00 & 91.8 & 220 & 22.0 & $\cdots$ & -. & $\ldots$ & .. & $\ldots$ & $\ldots$ & - & $\cdots$ & $\cdots$ & $\cdots$ & $\cdots$ & $\cdots$ & - & $\cdots$ & -- & $\ldots$ & .. & - \\
\hline $1 !-5-68$ & 0935 & -- & 11.05 & 97.5 & $-\infty$ & 9.4 & - & $\cdots$ & -. & $\cdots$ & $\ldots$ & $\cdots$ & -. & - & -- & - & -- & - & $\cdots$ & $\cdots$ & -- & $\cdots$ & $\cdots$ & 8,600 \\
\hline & & & & & & & & & & OH & A L.$A K$ & SAMPLIN & TATIO & 0.9 & & & & & & & & & & \\
\hline $\begin{array}{l}5-25-67 \\
6-6-67\end{array}$ & $\begin{array}{r}1145 \\
1620\end{array}$ & 7.7 & 8.00 & 82.8 & 290 & $\begin{array}{l}13.9 \\
66.8\end{array}$ & 9 & 37 & 8.7 & $\because$ & 5.3 & $\overline{0.9}$ & $\overline{10 i}$ & 45 & $9 . \bar{i}$ & .2 & .2 & .01 & $\because 10$ & $\begin{array}{l}-- \\
--\end{array}$ & $-:$ & 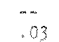 & 158 & $\begin{array}{r}2,600 \\
<1\end{array}$ \\
\hline $6+3-67$ & 1305 & $1 \%$ & 7.89 & 96.9 & 300 & 25.8 & $\because$ & 47 & $\approx$ & $\ldots$ & $\cdots$ & 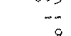 & $\cdots$ & $\ldots$ & $\cdots$ & $\approx$ & $\because$ & $\because$ & $\cdots$ & -- & -- & $\cdots$ & $\cdots$ & $<1$ \\
\hline $\begin{array}{l}6-20-67 \\
6-27 \times 67\end{array}$ & 1550 & 7.8 & $\begin{array}{l}7.20 \\
8.96\end{array}$ & $\begin{array}{r}81.4 \\
104.7\end{array}$ & $\begin{array}{l}275 \\
290\end{array}$ & $\begin{array}{l}21.2 \\
23.0\end{array}$ & 1.3 & 40 & $\begin{array}{c}9.5 \\
.\end{array}$ & 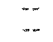 & 5.0 & .8 & 104 & ${ }^{52}$ & $\begin{array}{r}9.0 \\
-.\end{array}$ & .2 & $\therefore$ & .22 & .16 & $\therefore$ & $\cdots$ & .05 & 169 & $\begin{array}{l}4,300 \\
3,000+\end{array}$ \\
\hline $7.6-67$ & 1205 & .. & 8.54 & 98.4 & .. & 22.2 & $m$ & $\ldots$ & -. & $\ldots$ & .. & $\ldots$ & $\ldots$ & ... & -. & ... & -. & $\ldots$ & $\ldots$ & $\cdots$ & -. & $\ldots$ & -- & $10,500+$ \\
\hline $7010-67$ & 1440 & & 10. & 126.2 & 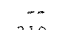 & 30 & $\cdots$ & - & $\because$ & -. & 5. & $\cdots$ & $\cdots$ & $\cdots$ & $\cdots$ & $\cdots$ & $\because$ & $\cdots$ & 13 & $\cdots$ & - & 28 & $\cdots$ & $65,400+$ \\
\hline $7-14-67$ & 1115 & 8.0 & 7.85 & 93.6 & 310 & 24 & 1.8 & 40 & 9.2 & $\cdots$ & 5.1 & .9 & 102 & 55 & 9.5 & .1 & .1 & .00 & .13 & $\cdots$ & $\cdots$ & .28 & 172 & $16,800+$ \\
\hline $7-18-67$ & 1500 & $=$ & 10.09 & 120.2 & $\because$ & $\begin{array}{l}2.4 .7 \\
74.7\end{array}$ & $\ldots$ & $\therefore$ & $\ldots$ & $\because$ & $\ldots$ & $\cdots$ & $\cdots$ & $\cdots$ & - & $\ldots$ & $\cdots$ & $\ldots$ & $\therefore$ & $\ldots$ & $\approx$ & $\ldots$ & $\because$ & $\begin{array}{l}7,900 * \\
10,000 *\end{array}$ \\
\hline & & .. & & 109.9 & $\ldots$ & 24.8 & -. & $\ldots$ & $\ldots$ & .. & . & $\ldots$ & $\ldots$ & ... & - & $\ldots$ & $\ldots$ & $\ldots$ & $-n$ & $\cdots$ & $\ldots$ & $\ldots$ & .. & \\
\hline $8-17-67$ & 1305 & 8.6 & 9.05 & 107.1 & $\begin{array}{l}315 \\
210\end{array}$ & $\begin{array}{l}23.8 \\
22\end{array}$ & $\cdots$ & $\begin{array}{l}40 \\
40\end{array}$ & $\because$ & - & z & $\approx$ & 102 & $\ldots$ & $\cdots$ & $\because$ & $\because$ & .00 & $\begin{array}{l}.00 \\
.08\end{array}$ & $\sqrt{12}$ & .34 & .05 & $\cdots$ & $\begin{array}{l}13,000 \\
43,5000\end{array}$ \\
\hline $\begin{array}{r}8-22-67 \\
9-27-57\end{array}$ & $\begin{array}{r}0955 \\
7400\end{array}$ & $\begin{array}{l}8.4 \\
8.7\end{array}$ & $\begin{array}{r}8.94 \\
1.42\end{array}$ & $\begin{array}{l}105.0 \\
120.8\end{array}$ & $\begin{array}{l}310 \\
290\end{array}$ & $\begin{array}{l}23.4 \\
17.8\end{array}$ & 1.5 & $\begin{array}{l}40 \\
4,2\end{array}$ & 9.2 & $\ldots$ & 5.5 & 1.0 & 106 & $55^{\circ}$ & 9.5 & .0 & .0 & .00 & .00 & .09 & .09 & .43 & 176 & 8,400 \\
\hline $10-9-67$ & 1250 & ... & 0.45 & 105.4 & 295 & 15.5 & $\ldots$ & $\ldots$ & $\ldots$ & $\ldots$ & $\cdots$ & $\ldots$ & -. & $\cdots$ & $\cdots$ & $\therefore$ & $\cdots$ & $\therefore$ & $\cdots$ & $\cdots$ & $\cdots$ & $\cdots$ & $\ldots$ & $550+$ \\
\hline $10-30-67$ & 1215 & 7.8 & 10.00 & 90.5 & 290 & 10.5 & 1.0 & 39 & 8.9 & -. & 5.2 & 3.2 & 104 & $5 !$ & 8.5 & .0 & .4 & .00 & .00 & .12 & $.2 !$ & .38 & 166 & 11,000 \\
\hline $12-4-67$ & 1700 & 7,7 & -. & $\ldots$ & 180 & w- & 4,3 & 22 & 6.2 & .14 & 3.8 & .8 & 69 & 23 & 7.2 & $\cdot ?$ & 1.4 & .00 & .00 & .10 & .42 & .34 & 103 & 400 \\
\hline $12-18-67$ & $\begin{array}{l}1130 \\
165\end{array}$ & 7.3 & $\ldots$ & $\therefore$ & $\begin{array}{r}98 \\
140\end{array}$ & .2 & $\begin{array}{l}3.8 \\
4.7\end{array}$ & 12 & $\begin{array}{l}3.5 \\
5.5\end{array}$ & .01 & 2. & .4 & $\begin{array}{l}38 \\
58 \\
\end{array}$ & 13 & $\begin{array}{l}3.5 \\
5.1\end{array}$ & .3 & $\begin{array}{l}1.1 \\
2.0\end{array}$ & $\begin{array}{l}.02 \\
.02\end{array}$ & $\begin{array}{l}.00 \\
.00\end{array}$ & .22 & .4 & $\begin{array}{l}.36 \\
.33\end{array}$ & $?$ & $\ldots$ \\
\hline $\begin{array}{l}-1508 \\
-29-68\end{array}$ & 1470 & 7.3 & .. & - & 140 & .0 & 4.6 & 16 & 5.2 & .00 & 2.6 & .3 & 59 & 13 & 6.0 & .1 & 1.8 & $.0\}$ & .13 & .03 & .54 & .02 & 79 & 40 \\
\hline
\end{tabular}


Sverdrup, H. U., Johnson, M. W., and Fleming, R. H., 1942, The oceans: their physics, chemistry, and general biology: Englewood Cliffs, PrenticeHall, $1087 \mathrm{p}$.

Talling, J.F., 1962, Freshwater algae: New York, Academic Press, 757 p.

Transeau, E. N., 1917, A new species and a new variety of algae from Oneida Lake: New York State Coll. Forestry Technology. Pub. no. 8, v. 17, p. 237-238.

U.S. Army Corps of Engineers, 1912a, Survey of the northern and northwestern lakes-New York State Canals, east end of Oneida Lake: U.S. Lake Survey Field sheet no. 1.

$1912 \mathrm{~b}$, Survey of the northern and northwestern lakes-New York State Canals, west end of Oneida Lake: U.S. Lake Survey Field Sheet no. 2.

U.S. Congress, House of Representatives Subcommittee of the Committee on Government Operations, 1966, Water pollution--Great Lakes (Part 2. Onondaga, Oneida, Ontario, and the Finger Lakes) Hearings: U.S. 89th Cong., 2 d sess., p. 281-464.

U.S. Department of Commerce, 1967, Local climatological data, Syracuse, New York, Hancock Field: U.S. Dept. Commerce, Environmental Data Service, $24 \mathrm{p}$.

1968, Local climatological data, Syracuse, New York, Hancock Field: U.S. Dept. Commerce, Environmental Data Service, $24 \mathrm{p}$.

1969, Local climatological data, Syracuse, New York, Hancock Field: U.S. Dept. Commerce, Environmental Data Service, 24 p.

U.S. Geological Survey, 1958, Compilation of records of surface waters of the United States through September 1950. Part 4. St. Lawrence River Basin: U.S. Geol. Survey Water-Supply Paper 1307, 397 p.

1968, Water resources data for New York, 1967. Part 1. Surface water records: U.S. Geol. Survey, Water Resources Div., 376 p.

1969a, Water resources data for New York, 1967. Part 2. Water quality records: U.S. Geol. Survey, Water Resources Div., 160 p.

1969b, Water resources data for New York, 1968. Part 1. Surface water records: U.S. Geol. Survey, Water Resources Div., 366 p.

1970a, Water resources data for New York, 1968. Part 2. Water qual ity records: U.S. Geol. Survey, Water Resources Div., 137 p.

1970b, Water resources data for New York, 1969. Part 1. Surface water records: U.S. Geol. Survey, Water Resources Div., 283 p.

1971, Water resources data for New York, 1969. Part 2. Water Quality records: U.S. Geol. Survey, Water Resources Div., 119 p. 
Voight, G. H., 1960, Alteration of the composition of rainwater by trees: Am. Midland Naturalist, v. 63, p. 321-329.

Wagner, Frederick E., 1928, Chemical investigation of the Oswego watershed, in A biological survey of the Oswego River System, Suppl. to 17 th Ann. Rept., 1927: New York State Conserv. Dept., p. 108-132.

Walker, J. B., 1953, Inorganic micronutrient requirements of ChIorelza. 1. Requirements for calcium (or strontium), copper, and molybdenum: Archives Biochemistry and Biophysics, v. 46, p. 1-11.

Welch, P. S., 1952, Limnology (2d ed.): New York, McGraw-Hill, 538 p. 
APPENDIX 



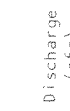

管

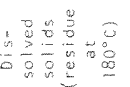

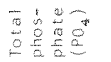

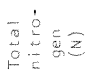

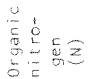

臬等

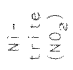

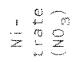

这可

혼둥

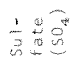

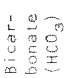

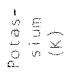

要

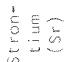

案的要

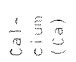

8

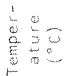

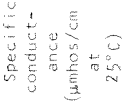

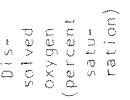

要焉

王

$\stackrel{0}{0}$

$\frac{5}{5}$
然娄学三

象

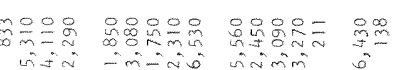

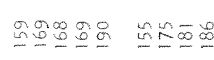

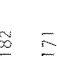

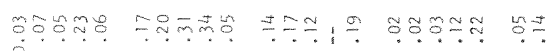

: 1: :

1:11

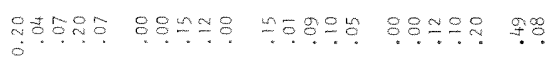

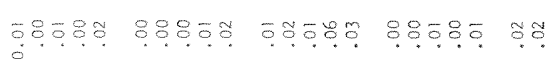

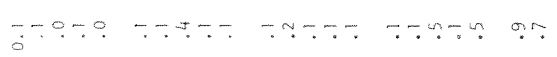

高

尊号

$\ldots \ldots+\ldots, \ldots$

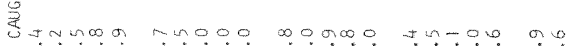

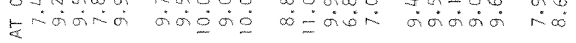

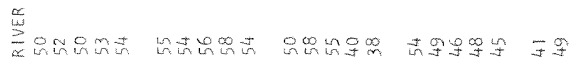

䨨

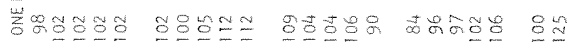

i

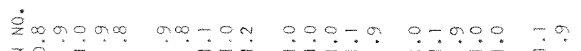

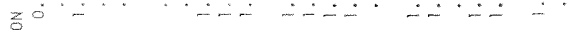

言

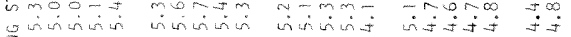

竞

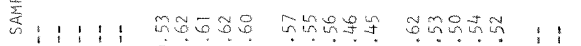

竞

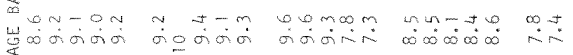

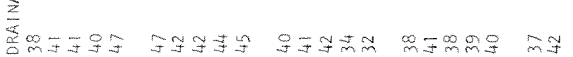

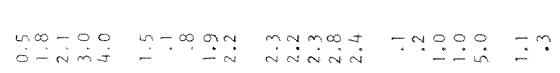

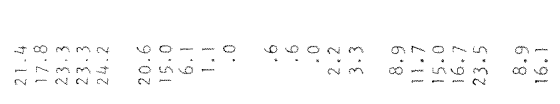

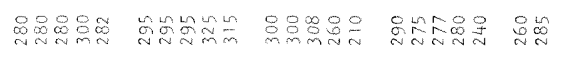

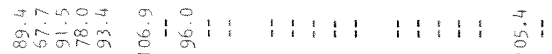

किकरन

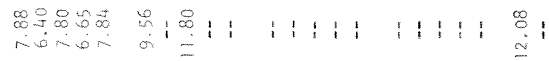

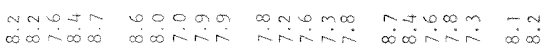

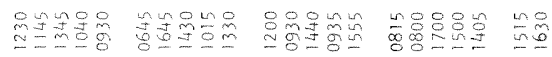

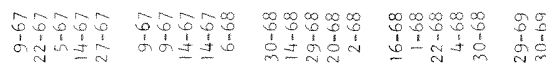

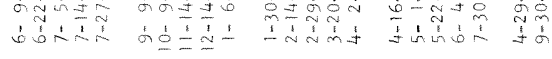

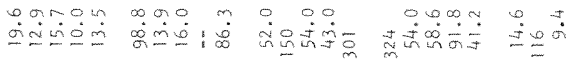

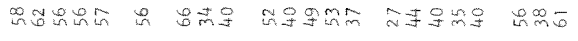

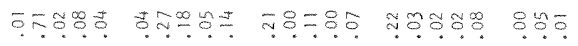

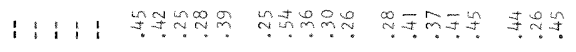

1111

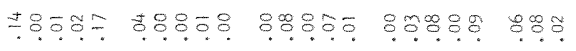

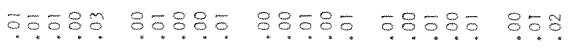

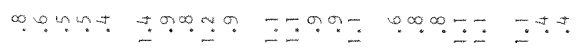

龺

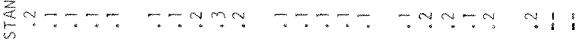

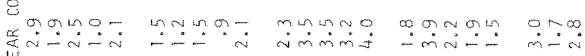

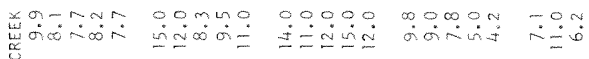

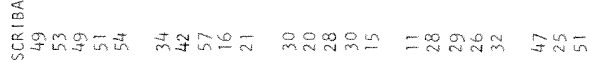

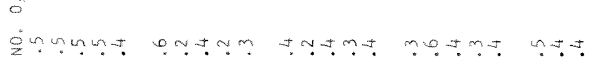

总

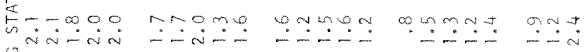

哭垔

意1:1: 1 :

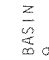

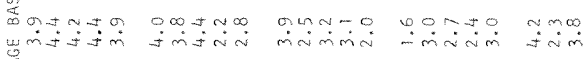

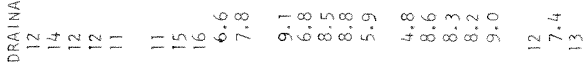

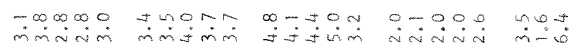

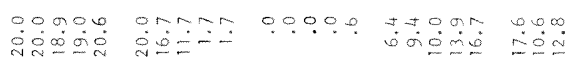

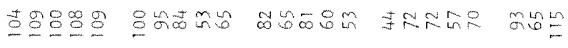

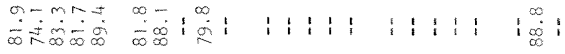

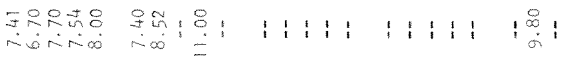

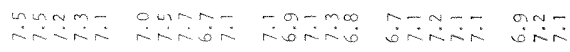

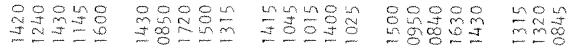

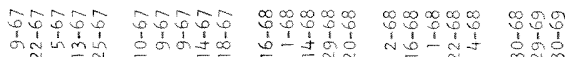

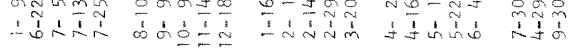




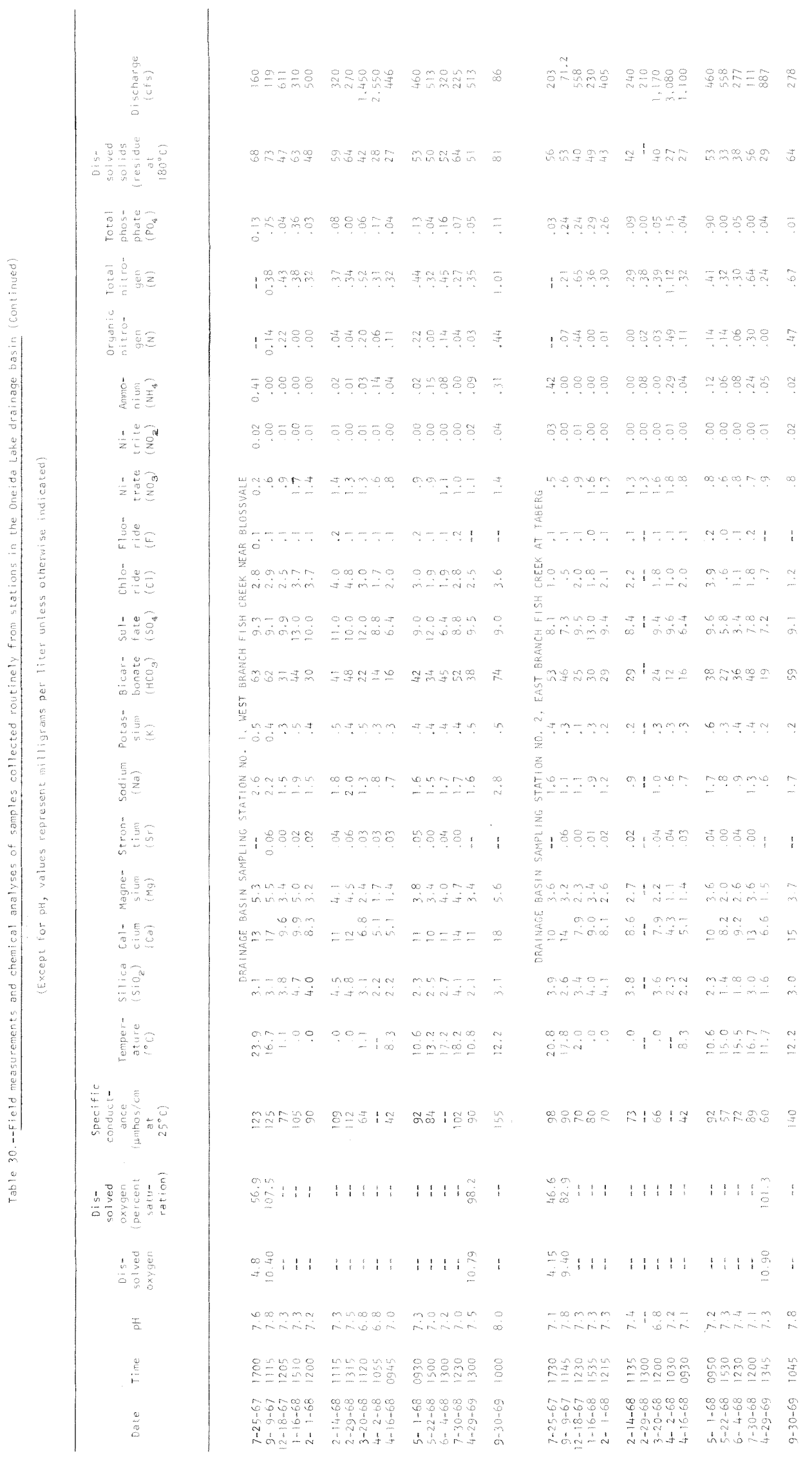


Table 30.--Field measurements and chemical analyses of samples collected routinely from stations in the Oneido Lake drainage basin (Continued)

(Excent for pH, values represent nilliarams per liter wess othervise indirated)

\begin{tabular}{|c|c|c|c|c|c|c|c|c|c|c|c|c|c|c|c|c|c|c|c|c|c|c|c|c|}
\hline Date & Tinie & $\mathrm{PH}$ & $\begin{array}{l}\text { Dis- } \\
\text { solved } \\
\text { oxygen }\end{array}$ & $\begin{array}{l}\text { Dis- } \\
\text { solved } \\
\text { oxygen } \\
\text { opcrent } \\
\text { satu- } \\
\text { ration! }\end{array}$ & $\begin{array}{c}\text { Specific } \\
\text { conduct- } \\
\text { ance } \\
(\mu m h o s / c m \\
\text { at } \\
\left.25^{\circ} \mathrm{C}\right)\end{array}$ & $\begin{array}{l}\text { Temper- } \\
\text { ature } \\
\left({ }^{\circ}{ }^{\circ}\right)\end{array}$ & $\begin{array}{l}\text { silica } \\
\text { (siog) }\end{array}$ & $\begin{array}{l}\text { Cal- } \\
\text { clues) } \\
\text { (Ca) }\end{array}$ & $\begin{array}{l}\text { Magne- } \\
\text { silum } \\
(\mathrm{Mg})\end{array}$ & $\begin{array}{l}\text { Stron- } \\
\text { tium } \\
(\mathrm{Sr})\end{array}$ & $\begin{array}{l}\text { Sodium } \\
(\mathrm{Na})\end{array}$ & $\begin{array}{l}\text { Potas- } \\
\text { sium } \\
(\mathrm{K})\end{array}$ & $\begin{array}{l}\text { Bicar- } \\
\text { bonate } \\
\left(\mathrm{HCO}_{3}\right)\end{array}$ & $\begin{array}{l}\text { sul- } \\
\text { fate } \\
\left(\mathrm{SO}_{4}\right)\end{array}$ & $\begin{array}{l}\text { Chlo- } \\
\text { ride } \\
\text { (cl) }\end{array}$ & $\begin{array}{l}\text { Fluo- } \\
\text { ride } \\
\text { (F) }\end{array}$ & $\begin{array}{l}\mathrm{Ni}- \\
\text { trate } \\
\left(\mathrm{NO}_{3}\right)\end{array}$ & $\begin{array}{l}\mathrm{Ni}- \\
t r i t e \\
\left(\mathrm{NO}_{2}\right)\end{array}$ & $\begin{array}{l}\text { Ammo- } \\
\text { nivum } \\
\left(\mathrm{NH}_{4}\right)\end{array}$ & $\begin{array}{l}\text { Organic } \\
\text { nitrom } \\
\text { gen } \\
\text { (N) }\end{array}$ & $\begin{array}{l}\text { Total } \\
\text { nition } \\
\text { gen } \\
(N)\end{array}$ & $\begin{array}{l}\text { Total } \\
\text { phos- } \\
\text { phate } \\
\left(\mathrm{PO}_{4}\right)\end{array}$ & $\begin{array}{c}\text { Dis.. } \\
\text { solved } \\
\text { solids } \\
\text { (residue } \\
\text { at } \\
\left.180^{\circ} \mathrm{c}\right)\end{array}$ & $\begin{array}{c}\text { Discharge } \\
(c t s)\end{array}$ \\
\hline $\begin{array}{r}10-10-67 \\
11-13-67 \\
12-13-67 \\
1-19-68 \\
2-1-68\end{array}$ & $\begin{array}{l}1140 \\
1515 \\
1400 \\
1100 \\
1020\end{array}$ & $\begin{array}{l}7.8 \\
7.0 \\
7.5 \\
7.6 \\
7.5\end{array}$ & $\begin{array}{c}-- \\
10.50 \\
-- \\
-- \\
--\end{array}$ & $\begin{array}{c}84.8 \\
-- \\
-- \\
--\end{array}$ & $\begin{array}{l}310 \\
150 \\
137 \\
300 \\
240\end{array}$ & $\begin{array}{r}13.1 \\
5.8 \\
1.7 \\
.0 \\
.0\end{array}$ & $\begin{array}{l}4.7 \\
4.0 \\
3.3 \\
5.0 \\
4.4\end{array}$ & $\begin{array}{l}\text { DRRAII } \\
37 \\
20 \\
13 \\
36 \\
27\end{array}$ & $\begin{array}{l}\text { INAGE BAS } \\
8.1 \\
4.9 \\
4.1 \\
9.1 \\
6.8\end{array}$ & $\begin{array}{c}\text { SIN SAMPI. } \\
0.46 \\
.04 \\
.06 \\
.22 \\
.15\end{array}$ & $\begin{array}{l}\text { ING STATI } \\
20 \\
3.7 \\
4.1 \\
8.4 \\
10\end{array}$ & $\begin{array}{c}\text { TION NO. } \\
1.7 \\
1.0 \\
.8 \\
1.2 \\
1.1\end{array}$ & $\begin{array}{c}3, \text { woot } \\
113 \\
64 \\
52 \\
124 \\
82\end{array}$ & $\begin{array}{c}\text { CREEK NE } \\
14 \\
13 \\
15 \\
26 \\
21\end{array}$ & $\begin{array}{l}\text { NEAR NEW } \\
40 \\
6.0 \\
6.1 \\
18 \\
20\end{array}$ & $\begin{array}{l}\text { LONDON } \\
0.2 \\
.2 \\
.1 \\
.1 \\
.1\end{array}$ & $\begin{array}{l}1.8 \\
1.2 \\
1.3 \\
4.2 \\
1.8\end{array}$ & $\begin{array}{l}0.01 \\
.00 \\
.02 \\
.07 \\
.02\end{array}$ & $\begin{array}{l}0.00 \\
.02 \\
.00 \\
.16 \\
.06\end{array}$ & $\begin{array}{l}0.03 \\
.12 \\
.21 \\
.00 \\
.07\end{array}$ & $\begin{array}{r}0.44 \\
.41 \\
.53 \\
1.09 \\
.53\end{array}$ & $\begin{array}{l}1.50 \\
.08 \\
.78 \\
.32 \\
.02\end{array}$ & $\begin{array}{r}185 \\
85 \\
75 \\
170 \\
132\end{array}$ & $\begin{array}{l}64 \\
443 \\
687 \\
120 \\
233\end{array}$ \\
\hline $\begin{array}{l}2-15-68 \\
3-7-68 \\
3-20-68 \\
4-3-68 \\
4-16-68\end{array}$ & $\begin{array}{l}1600 \\
1205 \\
1230 \\
1400 \\
1030\end{array}$ & $\begin{array}{l}8.0 \\
7.5 \\
6.8 \\
7.5 \\
8.0\end{array}$ & $\begin{array}{l}-- \\
-- \\
=- \\
-\end{array}$ & $\begin{array}{l}-- \\
=- \\
= \\
-\end{array}$ & $\begin{array}{l}300 \\
370 \\
130 \\
200 \\
285\end{array}$ & $\begin{array}{r}.0 \\
.0 \\
1.1 \\
7.8 \\
8.9\end{array}$ & $\begin{array}{l}4.9 \\
5.0 \\
3.0 \\
2.9 \\
2.8\end{array}$ & $\begin{array}{l}35 \\
38 \\
15 \\
26 \\
38\end{array}$ & $\begin{array}{l}10 \\
9.9 \\
3.8 \\
6.8 \\
8.4\end{array}$ & $\begin{array}{l}.21 \\
.25 \\
.10 \\
.16 \\
.26\end{array}$ & $\begin{array}{l}10 \\
24 \\
3.4 \\
6.0 \\
7.7\end{array}$ & $\begin{array}{l}1.2 \\
1.2 \\
1.0 \\
1.0 \\
1.2\end{array}$ & $\begin{array}{r}118 \\
122 \\
46 \\
86 \\
120\end{array}$ & $\begin{array}{l}23 \\
25 \\
15 \\
19 \\
29\end{array}$ & $\begin{array}{l}19 \\
42 \\
7.0 \\
12 \\
15\end{array}$ & $\begin{array}{l}.2 \\
.1 \\
.1 \\
.1 \\
.2\end{array}$ & $\begin{array}{l}3.8 \\
3.6 \\
1.3 \\
2.2 \\
1.9\end{array}$ & $\begin{array}{l}.02 \\
.01 \\
.02 \\
.01 \\
.00\end{array}$ & $\begin{array}{l}.01 \\
.15 \\
.02 \\
.00 \\
.05\end{array}$ & $\begin{array}{l}.27 \\
.09 \\
.13 \\
.08 \\
.05\end{array}$ & $\begin{array}{r}1.14 \\
1.02 \\
.45 \\
.58 \\
.52\end{array}$ & $\begin{array}{l}.05 \\
.02 \\
.04 \\
.11 \\
.19\end{array}$ & $\begin{array}{r}165 \\
209 \\
73 \\
118 \\
164\end{array}$ & $\begin{array}{r}103 \\
135 \\
587 \\
167 \\
98\end{array}$ \\
\hline $\begin{array}{l}5-1-68 \\
5-22-68 \\
6-7-68 \\
7-30-68 \\
4-29-69\end{array}$ & $\begin{array}{l}1115 \\
1245 \\
0930 \\
1120 \\
1220\end{array}$ & $\begin{array}{l}7.9 \\
7.7 \\
7.6 \\
7.5 \\
7.8\end{array}$ & $\begin{array}{c}-- \\
-- \\
-- \\
10.59\end{array}$ & $\begin{array}{c}= \\
=- \\
-- \\
93.4\end{array}$ & $\begin{array}{l}275 \\
205 \\
260 \\
185 \\
230\end{array}$ & $\begin{array}{r}10.0 \\
12.8 \\
15.4 \\
16.1 \\
9.4\end{array}$ & $\begin{array}{l}2.6 \\
3.2 \\
2.3 \\
4.5 \\
2.5\end{array}$ & $\begin{array}{l}31 \\
27 \\
33 \\
27 \\
30\end{array}$ & $\begin{array}{l}7.5 \\
6.5 \\
8.2 \\
6.4 \\
7.5\end{array}$ & $\begin{array}{l}.17 \\
.08 \\
.15 \\
.05 \\
--\end{array}$ & $\begin{array}{l}7.4 \\
5.8 \\
6.7 \\
4.7 \\
6.0\end{array}$ & $\begin{array}{l}1.1 \\
.9 \\
1.1 \\
1.0 \\
1.0\end{array}$ & $\begin{array}{r}106 \\
93 \\
120 \\
102 \\
106\end{array}$ & $\begin{array}{l}15 \\
13 \\
16 \\
12 \\
15\end{array}$ & $\begin{array}{c}16 \\
9.9 \\
12 \\
8.8 \\
10\end{array}$ & $\begin{array}{l}.2 \\
.1 \\
.2 \\
.3 \\
-.\end{array}$ & $\begin{array}{l}2.1 \\
1.4 \\
1.8 \\
1.7 \\
3.1\end{array}$ & $\begin{array}{l}.02 \\
.03 \\
.04 \\
.01 \\
.02\end{array}$ & $\begin{array}{l}.08 \\
.04 \\
.00 \\
.21 \\
.15\end{array}$ & $\begin{array}{l}.15 \\
.12 \\
.04 \\
.10 \\
.07\end{array}$ & $\begin{array}{l}.69 \\
.48 \\
.46 \\
.65 \\
.89\end{array}$ & $\begin{array}{l}.06 \\
.04 \\
.23 \\
.20 \\
.04\end{array}$ & $\begin{array}{l}135 \\
114 \\
141 \\
117 \\
127\end{array}$ & $\begin{array}{r}94 \\
130 \\
54 \\
75 \\
139\end{array}$ \\
\hline $9-30-69$ & 1145 & 8.0 & -- & -. & 240 & 13.9 & 2.5 & 32 & 5.0 & -- & 6.9 & 1.0 & 106 & 8.1 & 12 & -- & 3.1 & .04 & .10 & .15 & .23 & .12 & 123 & 43 \\
\hline $\begin{array}{l}6-8-67 \\
6-21-67 \\
7-7-67 \\
7-14-67 \\
7-26-67\end{array}$ & $\begin{array}{l}2020 \\
1645 \\
1100 \\
1445 \\
1330\end{array}$ & $\begin{array}{l}8.1 \\
8.6 \\
7.8 \\
8.0 \\
8.6\end{array}$ & $\begin{array}{r}6.65 \\
12.40 \\
6.50 \\
8.80 \\
11.90\end{array}$ & $\begin{array}{r}75.1 \\
149.9 \\
71.9 \\
97.1 \\
140.3\end{array}$ & $\begin{array}{l}800 \\
830 \\
820 \\
800 \\
740\end{array}$ & $\begin{array}{l}21.1 \\
25.0 \\
20.0 \\
19.9 \\
23.6\end{array}$ & $\begin{array}{l}1.1 \\
2.9 \\
4.0 \\
3.9 \\
4.6\end{array}$ & $\begin{array}{l}\text { ORAIN } \\
114 \\
126 \\
145 \\
107 \\
98\end{array}$ & $\begin{array}{l}\text { NAGE BASI: } \\
29 \\
30 \\
26 \\
27 \\
24\end{array}$ & $\begin{array}{c}\text { IN SAMPLII } \\
-- \\
-- \\
-- \\
--\end{array}$ & $\begin{array}{l}\text { ING STATIO } \\
13 \\
13 \\
17 \\
14 \\
11\end{array}$ & $\begin{array}{c}\text { ION NO. } 4 \\
2.6 \\
2.5 \\
3.2 \\
2.7 \\
2.6\end{array}$ & $\begin{array}{l}\text { 4, ONEIDA } \\
224 \\
235 \\
240 \\
243 \\
228\end{array}$ & $\begin{array}{l}\text { A CREEK A } \\
222 \\
231 \\
224 \\
200 \\
185\end{array}$ & $\begin{array}{l}\text { AT ONEII } \\
19 \\
20 \\
21 \\
20 \\
17\end{array}$ & $\begin{array}{l}\text { IDA VALLE } \\
.3 \\
.2 \\
.2 \\
.2 \\
.2 \\
.2\end{array}$ & $\begin{array}{r}.8 \\
.5 \\
2.4 \\
1.8 \\
1.7\end{array}$ & $\begin{array}{l}.66 \\
.67 \\
.86 \\
.36 \\
.12\end{array}$ & $\begin{array}{l}.66 \\
.15 \\
.51 \\
.00 \\
.98\end{array}$ & $\begin{array}{l}z \\
=- \\
z \\
z\end{array}$ & $\begin{array}{l}-- \\
-- \\
-- \\
--\end{array}$ & $\begin{array}{l}1.40 \\
.04 \\
1.15 \\
1.80 \\
1.20\end{array}$ & $\begin{array}{l}514 \\
548 \\
563 \\
498 \\
458\end{array}$ & $\begin{array}{l}69.0 \\
54.1 \\
-. \\
43.0 \\
47.8\end{array}$ \\
\hline $\begin{array}{r}8-10-67 \\
9-88-67 \\
10-10-67 \\
11-13-67 \\
12-13-67\end{array}$ & $\begin{array}{l}1225 \\
1310 \\
1045 \\
1435 \\
1545\end{array}$ & $\begin{array}{l}7.7 \\
8.3 \\
8.0 \\
7.5 \\
7.9\end{array}$ & $\begin{array}{c}6.60 \\
6.60 \\
10.20 \\
-.\end{array}$ & $\begin{array}{r}76.0 \\
74.5 \\
-3 . \\
84.3 \\
-.\end{array}$ & $\begin{array}{l}620 \\
900 \\
975 \\
580 \\
530\end{array}$ & $\begin{array}{r}22.2 \\
21.1 \\
13.3 \\
6.7 \\
3.3\end{array}$ & $\begin{array}{l}10 \\
.7 \\
3.8 \\
5.2 \\
4.1\end{array}$ & $\begin{array}{r}91 \\
150 \\
149 \\
88 \\
75\end{array}$ & $\begin{array}{l}22 \\
30 \\
26 \\
21 \\
18\end{array}$ & $\begin{array}{l}-- \\
2.9 \\
3.5 \\
1.5 \\
1.0\end{array}$ & $\begin{array}{c}14 \\
21 \\
18 \\
8.2 \\
7.2\end{array}$ & $\begin{array}{l}3.5 \\
2.9 \\
3.5 \\
2.8 \\
2.2\end{array}$ & $\begin{array}{l}208 \\
237 \\
264 \\
256 \\
224\end{array}$ & $\begin{array}{r}153 \\
253 \\
273 \\
101 \\
71\end{array}$ & $\begin{array}{l}24 \\
30 \\
23 \\
14 \\
12\end{array}$ & $\begin{array}{l}.1 \\
.1 \\
.2 \\
.2 \\
.1\end{array}$ & $\begin{array}{l}1.7 \\
2.9 \\
2.5 \\
2.9 \\
4.1\end{array}$ & $\begin{array}{l}.56 \\
.03 \\
.21 \\
.02 \\
.03\end{array}$ & $\begin{array}{l}.31 \\
.07 \\
.38 \\
.34 \\
.07\end{array}$ & $\begin{array}{l}.11 \\
.17 \\
.12 \\
.00 \\
.11\end{array}$ & $\begin{array}{r}.90 \\
.89 \\
1.04 \\
.90 \\
1.10\end{array}$ & $\begin{array}{r}.51 \\
3.00 \\
1.10 \\
.25 \\
.21\end{array}$ & $\begin{array}{l}423 \\
625 \\
634 \\
371 \\
305\end{array}$ & $\begin{array}{c}181 \\
31.7 \\
38.0 \\
-89\end{array}$ \\
\hline $\begin{array}{l}1-19-68 \\
2-2-68 \\
2-16-68 \\
3-1-68 \\
3-10-58\end{array}$ & $\begin{array}{l}1430 \\
0915 \\
1415 \\
1045 \\
1500\end{array}$ & $\begin{array}{l}7.8 \\
7.8 \\
7.6 \\
7.6 \\
7.8\end{array}$ & $\begin{array}{l}= \\
= \\
= \\
=\end{array}$ & $\begin{array}{l}= \\
=- \\
=- \\
=\end{array}$ & $\begin{array}{l}900 \\
540 \\
8- \\
867 \\
420\end{array}$ & $\begin{array}{r}.0 \\
.0 \\
.0 \\
.0 \\
3.3\end{array}$ & $\begin{array}{l}5.1 \\
4.2 \\
4.9 \\
4.9 \\
3.6\end{array}$ & $\begin{array}{r}124 \\
70 \\
125 \\
131 \\
63\end{array}$ & $\begin{array}{l}29 \\
18 \\
29 \\
29 \\
15\end{array}$ & $\begin{array}{r}2.9 \\
1.1 \\
2.6 \\
3.0 \\
.8\end{array}$ & $\begin{array}{l}10 \\
8.7 \\
11 \\
14 \\
5.8\end{array}$ & $\begin{array}{l}2.0 \\
2.0 \\
1.9 \\
2.1 \\
1.9\end{array}$ & $\begin{array}{l}291 \\
206 \\
293 \\
285 \\
186\end{array}$ & $\begin{array}{r}195 \\
75 \\
187 \\
211 \\
58\end{array}$ & $\begin{array}{l}18 \\
16 \\
19 \\
22 \\
12\end{array}$ & $\begin{array}{l}.1 \\
.2 \\
.2 \\
.1 \\
.1\end{array}$ & $\begin{array}{l}4.6 \\
3.5 \\
4.8 \\
3.7 \\
3.8\end{array}$ & $\begin{array}{l}.03 \\
.03 \\
.04 \\
.05 \\
.02\end{array}$ & $\begin{array}{l}.44 \\
.00 \\
.25 \\
.37 \\
.11\end{array}$ & $\begin{array}{r}1.20 \\
.16 \\
.12 \\
.19 \\
.09\end{array}$ & $\begin{array}{r}2.59 \\
.96 \\
1.41 \\
1.33 \\
1.04\end{array}$ & $\begin{array}{l}.78 \\
.16 \\
.59 \\
.77 \\
.13\end{array}$ & $\begin{array}{l}535 \\
300 \\
530 \\
562 \\
2.55\end{array}$ & $\begin{array}{l}93.0 \\
7.0 \\
54.0 \\
85.0 \\
754\end{array}$ \\
\hline $\begin{array}{l}4-3-68 \\
4-16-68 \\
5-1-68 \\
5-22-68 \\
6-6-68\end{array}$ & $\begin{array}{l}1300 \\
130 \\
1400 \\
1300 \\
1600\end{array}$ & $\begin{array}{l}8.3 \\
8.3 \\
8.0 \\
7.9 \\
8.5\end{array}$ & $\begin{array}{l}-- \\
-- \\
-- \\
--\end{array}$ & $\begin{array}{l}-- \\
-- \\
-- \\
--\end{array}$ & $\begin{array}{l}525 \\
630 \\
754 \\
610 \\
770\end{array}$ & $\begin{array}{c}9.4 \\
12.2 \\
-2 . \\
13.3 \\
16.4\end{array}$ & $\begin{array}{r}2.9 \\
.8 \\
.5 \\
3.5 \\
1.5\end{array}$ & $\begin{array}{r}88 \\
113 \\
117 \\
101 \\
110\end{array}$ & $\begin{array}{l}21 \\
26 \\
26 \\
24 \\
27\end{array}$ & $\begin{array}{l}1.6 \\
2.3 \\
2.6 \\
1.8 \\
2.5\end{array}$ & $\begin{array}{l}7.7 \\
10 \\
12 \\
10 \\
16\end{array}$ & $\begin{array}{l}1.7 \\
1.9 \\
2.2 \\
1.8 \\
2.1\end{array}$ & $\begin{array}{l}252 \\
262 \\
262 \\
266 \\
258\end{array}$ & $\begin{array}{r}96 \\
164 \\
174 \\
134 \\
178\end{array}$ & $\begin{array}{l}15 \\
18 \\
21 \\
16 \\
23\end{array}$ & $\begin{array}{l}.1 \\
.2 \\
.3 \\
.1 \\
.2\end{array}$ & $\begin{array}{l}3.4 \\
1.5 \\
1.6 \\
1.7 \\
1.5\end{array}$ & $\begin{array}{l}.01 \\
.04 \\
.07 \\
.09 \\
.30\end{array}$ & $\begin{array}{l}.06 \\
.12 \\
.04 \\
.24 \\
.24\end{array}$ & $\begin{array}{l}.19 \\
.00 \\
.14 \\
.10 \\
.13\end{array}$ & $\begin{array}{l}1.01 \\
.44 \\
.55 \\
.70 \\
.75\end{array}$ & $\begin{array}{r}.32 \\
.60 \\
.47 \\
.73 \\
1.20\end{array}$ & $\begin{array}{l}362 \\
467 \\
487 \\
425 \\
490\end{array}$ & $\begin{array}{c}237 \\
132 \\
116 \\
163 \\
76.1\end{array}$ \\
\hline $\begin{array}{l}6-28-68 \\
7-30-68 \\
4-29-69 \\
9-30-69\end{array}$ & $\begin{array}{l}1515 \\
0930 \\
1000 \\
1255\end{array}$ & $\begin{array}{l}7.7 \\
7.7 \\
8.2 \\
8.2\end{array}$ & $\begin{array}{c}-- \\
10.89 \\
--\end{array}$ & $\begin{array}{c}-- \\
90.0 \\
--\end{array}$ & $\begin{array}{l}397 \\
809 \\
600 \\
950\end{array}$ & $\begin{array}{r}18.0 \\
19.4 \\
6.7 \\
14.4\end{array}$ & $\begin{array}{l}4.9 \\
1.5 \\
1.9 \\
2.7\end{array}$ & $\begin{array}{r}57 \\
117 \\
92 \\
156\end{array}$ & $\begin{array}{l}13 \\
29 \\
20 \\
28\end{array}$ & $\begin{array}{r}.7 \\
2.8 \\
-.\end{array}$ & $\begin{array}{l}4.6 \\
15 \\
7.5 \\
19\end{array}$ & $\begin{array}{l}2.6 \\
2.5 \\
1.6 \\
3.2\end{array}$ & $\begin{array}{l}179 \\
252 \\
264 \\
213\end{array}$ & $\begin{array}{r}45 \\
200 \\
96 \\
313\end{array}$ & $\begin{array}{l}8.0 \\
26 \\
12 \\
23\end{array}$ & $\begin{array}{l}.0 \\
.3 \\
-. \\
-.\end{array}$ & $\begin{array}{l}4.5 \\
1.5 \\
3.2 \\
5.1\end{array}$ & $\begin{array}{l}.05 \\
.22 \\
.04 \\
.09\end{array}$ & $\begin{array}{l}.03 \\
.24 \\
.14 \\
.10\end{array}$ & $\begin{array}{l}.14 \\
.23 \\
.07 \\
.36\end{array}$ & $\begin{array}{r}1.20 \\
.82 \\
.91 \\
1.62\end{array}$ & $\begin{array}{r}.16 \\
1.00 \\
.23 \\
2.40\end{array}$ & $\begin{array}{l}228 \\
521 \\
364 \\
658\end{array}$ & $\begin{array}{r}1,900 \\
56.3 \\
245 \\
24.0\end{array}$ \\
\hline
\end{tabular}




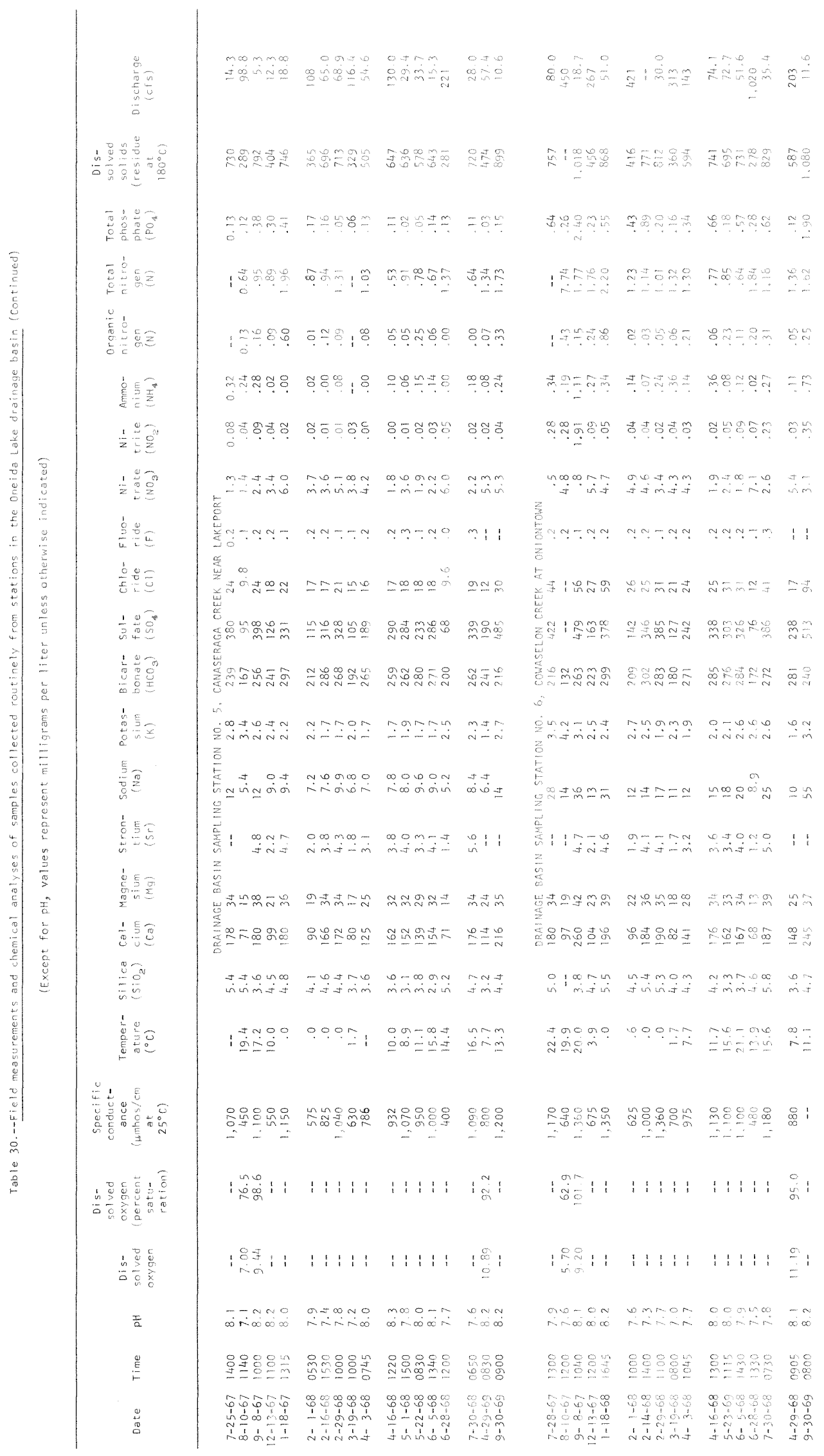




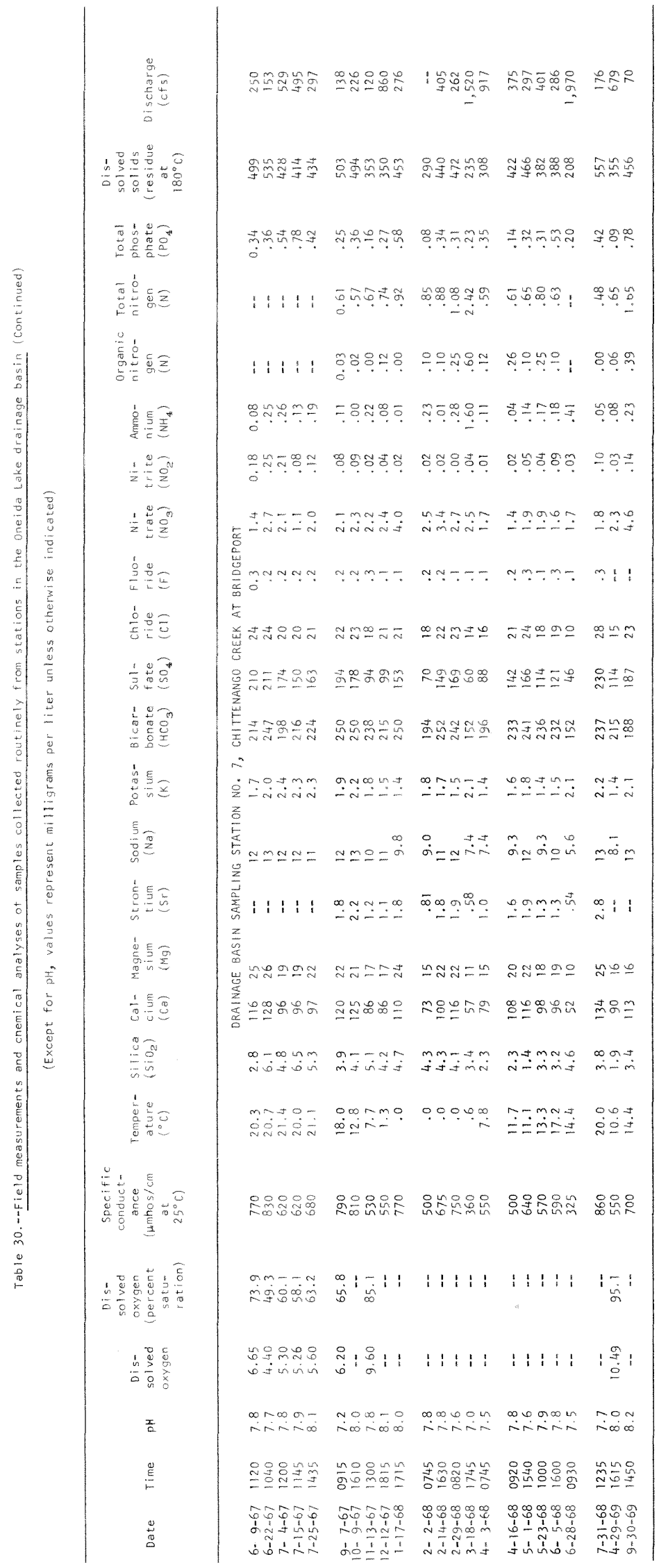




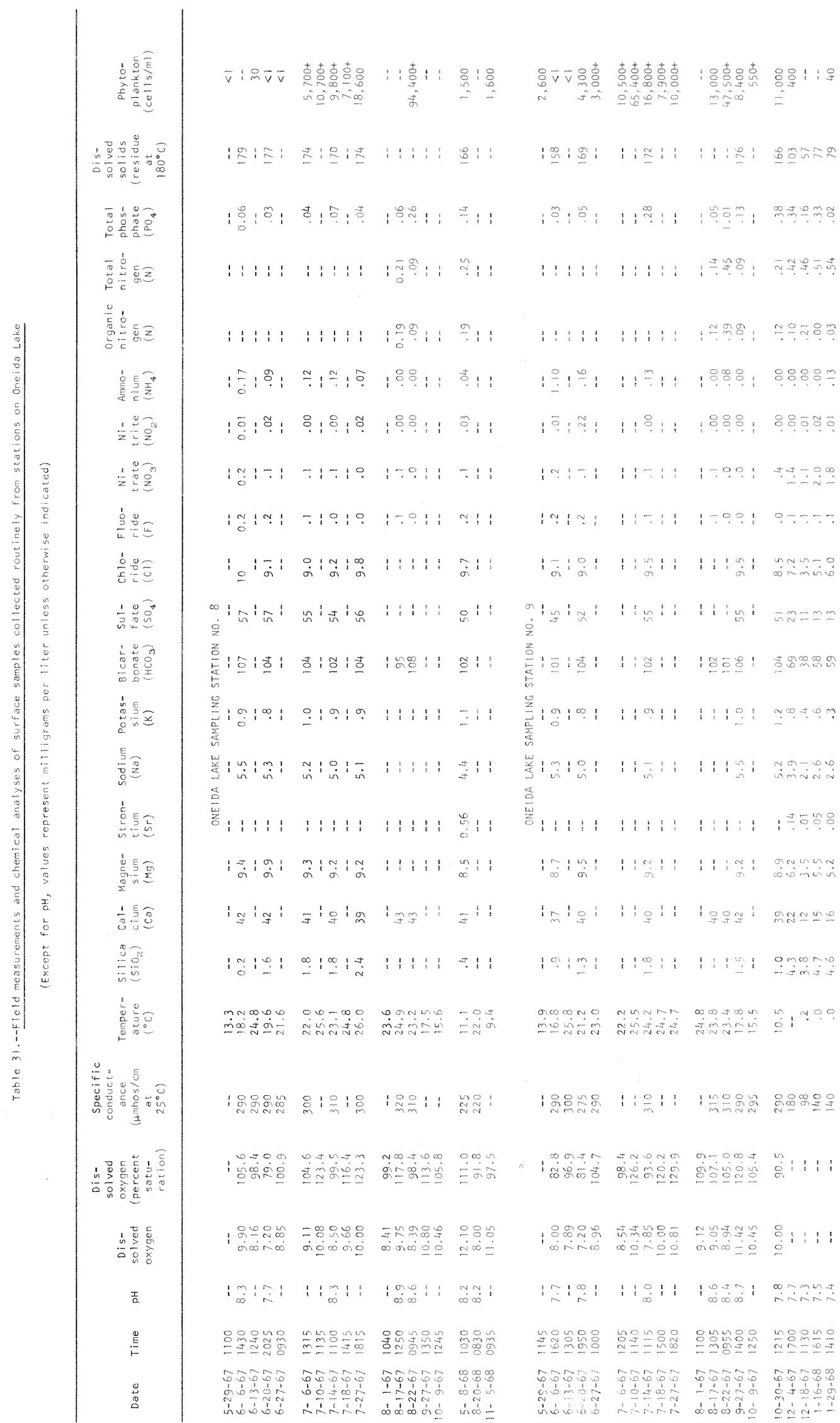


Table 31.-.-Field measurements and chemical analyses of surface samples collested routinely from stations on Gnesia Lake (Continued)

(Except for pH, values rearesent milligrams oer liter unless otherwise indicated)

\begin{tabular}{|c|c|c|c|c|c|c|c|c|c|c|c|c|c|c|c|c|c|c|c|c|c|c|c|c|}
\hline Date & Time & $\mathrm{pH}$ & $\begin{array}{l}\text { Dis- } \\
\text { solved } \\
\text { oxygen }\end{array}$ & $\begin{array}{l}\text { Dis- } \\
\text { solved } \\
\text { oxygen } \\
\text { (percent } \\
\text { satü } \\
\text { ration) }\end{array}$ & $\begin{array}{c}\text { Specific } \\
\text { conduct- } \\
\text { ance } \\
(\text { mhos } / \mathrm{cm} \\
\text { ot } \\
\left.25^{\circ} \mathrm{C}\right)\end{array}$ & $\begin{array}{l}\text { Temper- } \\
\text { ature } \\
\left({ }^{\circ} \mathrm{C}\right)\end{array}$ & $\begin{array}{l}\text { Silica } \\
\left(\mathrm{SiO}_{2}\right)\end{array}$ & $\begin{array}{l}\text { cal- } \\
\text { cium } \\
\text { (ca) }\end{array}$ & $\begin{array}{l}\text { Magre- } \\
\text { sium } \\
\left(M_{g}\right)\end{array}$ & $\begin{array}{l}\text { Stron- } \\
\text { eium } \\
(\text { Sir })\end{array}$ & $\underset{\substack{\text { Sodium } \\
\text { (Na) }}}{\text {. }}$ & $\begin{array}{l}\text { Potás- } \\
\text { siunto } \\
\text { (K) }\end{array}$ & $\begin{array}{l}\text { Bicar- } \\
\text { bonate } \\
\left(\mathrm{HCO}_{3}\right)\end{array}$ & $\begin{array}{l}\text { Sul- } \\
\text { fate } \\
\left.(50)_{4}\right)\end{array}$ & $\begin{array}{l}\text { Chlo- } \\
\text { ride } \\
\text { (ci) }\end{array}$ & $\begin{array}{l}\text { Fluo- } \\
\text { ride } \\
\text { (f) }\end{array}$ & $\begin{array}{l}\mathrm{Ni}- \\
\text { trate } \\
\left(\mathrm{NO}_{3}\right)\end{array}$ & $\begin{array}{l}\mathrm{Ni}- \\
\text { trite } \\
\left(\mathrm{NO}_{2}\right)\end{array}$ & $\begin{array}{l}\text { Antrmo- } \\
\text { niung } \\
\left(\mathrm{WH}_{4}\right)\end{array}$ & $\begin{array}{l}\text { Drganic } \\
\text { nitro- } \\
\text { gen } \\
(\mathrm{N})\end{array}$ & $\begin{array}{l}\text { Total } \\
\text { nitro- } \\
\text { gen } \\
(N)\end{array}$ & $\begin{array}{l}\text { Total } \\
\text { phos- } \\
\text { phate } \\
\left(\mathrm{PO}_{4}\right)\end{array}$ & $\begin{array}{l}\text { Dis- } \\
\text { solved } \\
\text { solids } \\
(\text { residue } \\
\text { at } \\
\left.180^{\circ} \mathrm{C}\right)\end{array}$ & $\begin{array}{c}\text { Phyto- } \\
\text { Plankton } \\
\text { (cells/mini) }\end{array}$ \\
\hline
\end{tabular}

\begin{tabular}{|c|c|c|c|c|c|c|c|c|c|c|c|c|c|c|c|c|c|c|c|c|c|c|c|c|}
\hline $\begin{array}{l}2-13-68 \\
2-27-68 \\
4-18-68 \\
5-8-68 \\
6-8-68\end{array}$ & $\begin{array}{l}1445 \\
1300 \\
1030 \\
1055 \\
0925\end{array}$ & $\begin{array}{l}7.3 \\
7.4 \\
7.5 \\
7.8 \\
7.7\end{array}$ & $\begin{array}{c}-- \\
-- \\
11.70 \\
10.40\end{array}$ & $\begin{array}{c}-- \\
- \\
110.1 \\
107.8\end{array}$ & $\begin{array}{l}150 \\
150 \\
220 \\
200\end{array}$ & $\begin{array}{r}0.0 \\
.0 \\
10.0 \\
12.2 \\
16.8\end{array}$ & $\begin{array}{l}4.4 \\
4.8 \\
2.3 \\
1.0 \\
1.9\end{array}$ & $\begin{array}{l}14 \\
18 \\
18 \\
35 \\
25\end{array}$ & $\begin{array}{l}0.8 \\
4.8 \\
5.6 \\
4.6 \\
7.8 \\
6.2\end{array}$ & $\begin{array}{r}10 A \\
0.06 \\
.11 \\
.21 \\
.46 \\
.27\end{array}$ & $\begin{array}{r}\text { SAMP } \\
2.3 \\
3.0 \\
5.3 \\
4.1 \\
3.3\end{array}$ & $\begin{array}{r}\text { NG STA } \\
0.5 \\
.6 \\
.7 \\
.9 \\
.7\end{array}$ & $\begin{array}{r}\text { No. } \\
50 \\
60 \\
58 \\
91 \\
75\end{array}$ & $\begin{array}{c}\text { Conti } \\
16 \\
15 \\
22 \\
47 \\
27\end{array}$ & $\begin{array}{l}\text { ued) } \\
5.5 \\
6.5 \\
6.9 \\
9.5 \\
6.0\end{array}$ & $\begin{array}{l}0.2 \\
.0 \\
.2 \\
.2 \\
.3\end{array}$ & $\begin{array}{r}1.5 \\
1.8 \\
.8 \\
.2 \\
1.2\end{array}$ & $\begin{array}{l}0.00 \\
.00 \\
.00 \\
.03 \\
.00\end{array}$ & $\begin{array}{l}0.00 \\
.38 \\
.00 \\
.08 \\
.08\end{array}$ & $\begin{array}{r}0.01 \\
.18 \\
.15 \\
.09 \\
.04\end{array}$ & $\begin{array}{r}0.35 \\
.88 \\
.33 \\
.21 \\
.37\end{array}$ & $\begin{array}{r}0.06 \\
.02 \\
.13 \\
.01 \\
.15\end{array}$ & $\begin{array}{r}73 \\
86 \\
89 \\
146 \\
109\end{array}$ & $\begin{array}{l}<1 \\
<1 \\
-1 \\
100\end{array}$ \\
\hline $\begin{array}{l}6-14-68 \\
7-10-68 \\
7-15-68 \\
7-24-68 \\
8-6-68\end{array}$ & $\begin{array}{l}0900 \\
0700 \\
1710 \\
0815 \\
1730\end{array}$ & $\begin{array}{l}-- \\
-- \\
z-\end{array}$ & $\begin{array}{r}10.14 \\
8.85 \\
11.48 \\
10.70 \\
11.40\end{array}$ & $\begin{array}{l}108.7 \\
103.4 \\
133.6 \\
129.8 \\
133.8\end{array}$ & $\begin{array}{l}280 \\
260 \\
240 \\
225\end{array}$ & $\begin{array}{l}18.4 \\
23.0 \\
22.8 \\
25.2 \\
23.3\end{array}$ & $\begin{array}{r}-. \\
-.2 \\
-- \\
2.3\end{array}$ & $\begin{array}{c}-- \\
76 \\
41\end{array}$ & $\begin{array}{r}-. \\
8.1 \\
\overline{8.9}\end{array}$ & $\begin{array}{l}-. \\
-.50 \\
-.53\end{array}$ & $\begin{array}{r}-- \\
4.7 \\
-\overline{-} \\
4.6\end{array}$ & $\begin{array}{r}-- \\
-1.0 \\
-0 \\
1.0\end{array}$ & $\begin{array}{c}\ddot{-} \\
100 \\
\overline{104}\end{array}$ & $\begin{array}{c}39 \\
48\end{array}$ & $\begin{array}{r}-- \\
9.0 \\
\overline{9.3}\end{array}$ & $\begin{array}{l}-. \\
-1 \\
-2 \\
.2\end{array}$ & $\begin{array}{c}-. \\
.3 \\
.3 \\
-1.1\end{array}$ & $\begin{array}{l}-- \\
-. \\
.02 \\
.00 \\
.00\end{array}$ & $\begin{array}{l}-- \\
-. \\
.05 \\
.08\end{array}$ & $\begin{array}{l}-- \\
-.07 \\
-- \\
.10\end{array}$ & $\begin{array}{l}-. \\
.18 \\
.41\end{array}$ & $\begin{array}{l}-- \\
-12 \\
-8 \\
.03\end{array}$ & $\begin{array}{l}-z \\
150 \\
16 \\
168\end{array}$ & $\begin{array}{r}200 \\
400 \\
m- \\
12,300+ \\
4,200\end{array}$ \\
\hline $\begin{array}{r}8-20-68 \\
8-28-68 \\
9-24-68 \\
10-23-68 \\
1-6-69\end{array}$ & $\begin{array}{l}0840 \\
0930 \\
1135 \\
0945 \\
1200\end{array}$ & $\begin{array}{r}8.1 \\
-2 \\
7.4 \\
7.5\end{array}$ & $\begin{array}{l}8.18 \\
10.10 \\
10.90 \\
10.05 \\
12.00\end{array}$ & $\begin{array}{r}93.6 \\
115.6 \\
124.0 \\
98.2 \\
82.3\end{array}$ & $\begin{array}{r}240 \\
-\because \\
120\end{array}$ & $\begin{array}{r}21.8 \\
21.8 \\
21.5 \\
14.0 \\
.0\end{array}$ & $\begin{array}{r}3.7 \\
-.- \\
4.3 \\
4.5\end{array}$ & $\begin{array}{l}40 \\
-7 \\
40 \\
14\end{array}$ & $\begin{array}{r}8.9 \\
- \\
0.3 \\
8.3 \\
4.4\end{array}$ & $\begin{array}{l}=56 \\
=- \\
=- \\
=\end{array}$ & $\begin{array}{r}4.9 \\
-- \\
5.0 \\
2.2\end{array}$ & $\begin{array}{r}1.1 \\
-. . \\
1.1 \\
.4\end{array}$ & $\begin{array}{c}104 \\
\cdots \\
104 \\
50\end{array}$ & $\begin{array}{c}47 \\
\because- \\
45 \\
13\end{array}$ & $\begin{array}{r}9.0 \\
-0 \\
8.8 \\
3.9\end{array}$ & $\begin{array}{l}.1 \\
-z \\
-z \\
-.\end{array}$ & $\begin{array}{l}.4 \\
-- \\
.0 \\
.8\end{array}$ & $\begin{array}{l}.00 \\
-0 \\
-.00 \\
.00\end{array}$ & $\begin{array}{l}.13 \\
-1 \\
-12 \\
.12\end{array}$ & $\begin{array}{l}.02 \\
-. \\
-.16 \\
.02\end{array}$ & $\begin{array}{l}.21 \\
-. \\
.25 \\
.29\end{array}$ & $\begin{array}{l}.13 \\
-2 \\
-12 \\
.17 \\
.17\end{array}$ & $\begin{array}{c}167 \\
7- \\
164 \\
67\end{array}$ & $\begin{array}{c}22,200+ \\
43,500+ \\
-- \\
400+ \\
10\end{array}$ \\
\hline $8-14-69$ & 1320 & 8.6 & -- & -- & 265 & 24.4 & 2.9 & 41 & 7.4 & -- & 4.7 & .9 & 94 & 49 & 8.2 & -- & .0 & .01 & .45 & .22 & .57 & .10 & 163 & -- \\
\hline $\begin{array}{l}5-29-67 \\
6-6-67 \\
6-13-67 \\
6-20-67 \\
6-27-67\end{array}$ & $\begin{array}{l}1230 \\
1715 \\
1325 \\
1820 \\
1020\end{array}$ & $\begin{array}{r}8 .- \\
8.5 \\
. .-\end{array}$ & $\begin{array}{r}10 \\
10.00 \\
7.59 \\
8.20 \\
9.50\end{array}$ & $\begin{array}{r}109.2 \\
96.9 \\
96.1 \\
110.0\end{array}$ & $\begin{array}{l}280 \\
280 \\
290 \\
275\end{array}$ & $\begin{array}{l}13.3 \\
19.4 \\
25.8 \\
23.2 \\
22.5\end{array}$ & $\begin{array}{l}-. \\
.3 \\
.6 \\
.6\end{array}$ & $\begin{array}{l}41^{--} \\
40- \\
--\end{array}$ & $\begin{array}{r}9.1 \\
9.6 \\
--\end{array}$ & $\begin{array}{l}\text { ONE } \\
-\because \\
=- \\
=-\end{array}$ & $\begin{array}{r}\text { LAK } \\
5.3 \\
-- \\
5.0 \\
--\end{array}$ & $\begin{array}{r}\text { SAMPLI } \\
-.8 \\
.8 \\
.8 \\
-.\end{array}$ & $\begin{array}{c}\text { Statio } \\
104 \\
\overline{104} \\
--\end{array}$ & $\begin{array}{c}\text { No. } 10 \\
52 \\
- \\
54 \\
--\end{array}$ & $\begin{array}{r}\overline{9.2} \\
8 . \overline{2}\end{array}$ & $\begin{array}{l}. .2 \\
.2 \\
.2 \\
-.\end{array}$ & $\begin{array}{l}-. \\
.2 \\
-1 \\
-.\end{array}$ & $\begin{array}{l}-. \\
.01 \\
-.00 \\
--\end{array}$ & $\begin{array}{l}.24 \\
.24 \\
.10\end{array}$ & $\begin{array}{l}=- \\
=- \\
= \\
=\end{array}$ & $\begin{array}{l}= \\
= \\
= \\
=\end{array}$ & $\begin{array}{l}-. \\
.03 \\
-0 \\
.02 \\
--\end{array}$ & $\begin{array}{r}169 \\
170 \\
--\end{array}$ & $\begin{array}{r}2,200 \\
<1 \\
<1 \\
<1 \\
<1\end{array}$ \\
\hline $\begin{array}{l}7-6-67 \\
7-10-67 \\
7-14-67 \\
7-18-67 \\
7-27-67\end{array}$ & $\begin{array}{l}1150 \\
1230 \\
1235 \\
1510 \\
1830\end{array}$ & $\begin{array}{r}\because \\
7.9 \\
- \\
-\end{array}$ & $\begin{array}{r}8.98 \\
11.27 \\
7.92 \\
10.08 \\
10.53\end{array}$ & $\begin{array}{r}102.2 \\
138.4 \\
94.1 \\
121.7 \\
129.4\end{array}$ & $\begin{array}{r}280 \\
290 \\
300\end{array}$ & $\begin{array}{l}21.5 \\
28.5 \\
24.0 \\
24.9 \\
25.8\end{array}$ & $\begin{array}{r}1.8 \\
-1.9 \\
-7.4 \\
2.4\end{array}$ & $\begin{array}{l}41 \\
39 \\
39 \\
39\end{array}$ & $\begin{array}{l}9.1 \\
9.1 \\
9.0\end{array}$ & $\begin{array}{l}\ddot{-} \\
\ddot{-} \\
=\end{array}$ & $\begin{array}{r}5.1 \\
5.0 \\
5.0\end{array}$ & $\begin{array}{r}1.0 \\
.-9 \\
.9 \\
.9\end{array}$ & $\begin{array}{c}103 \\
\overline{101} \\
104\end{array}$ & $\begin{array}{l}57 \\
53 \\
55\end{array}$ & $\begin{array}{r}8.9 \\
8.8 \\
-- \\
9.5\end{array}$ & $\begin{array}{l}.1 \\
-1 \\
.1 \\
.1\end{array}$ & $\begin{array}{l}.1 \\
-1 \\
.1\end{array}$ & $\begin{array}{l}.00 \\
-0 \\
.00 \\
.02\end{array}$ & $\begin{array}{l}.12 \\
.05 \\
.10\end{array}$ & $\begin{array}{l}= \\
=- \\
-- \\
-\end{array}$ & $\begin{array}{l}-- \\
= \\
-- \\
-\end{array}$ & $\begin{array}{l}.04 \\
-.22 \\
-.04 \\
.04\end{array}$ & $\begin{array}{l}175 \\
168 \\
172\end{array}$ & $\begin{array}{r}11,200+ \\
46,000+ \\
6,400+ \\
6,600+ \\
18,700+\end{array}$ \\
\hline $\begin{array}{l}8-1-67 \\
8-17-67 \\
8-22-67 \\
9-2767 \\
10-9-67\end{array}$ & $\begin{array}{l}1050 \\
1315 \\
0930 \\
1145 \\
1255\end{array}$ & $\begin{array}{r}8.6 \\
8.6 \\
8 \\
--\end{array}$ & $\begin{array}{r}9.22 \\
8.66 \\
7.68 \\
10.47 \\
10.30\end{array}$ & $\begin{array}{r}111.5 \\
103.2 \\
90.0 \\
111.0 \\
104.8\end{array}$ & $\begin{array}{r}-10 \\
350 \\
--\end{array}$ & $\begin{array}{l}25.0 \\
24.2 \\
23.2 \\
17.9 \\
15.9\end{array}$ & $\begin{array}{l}-- \\
=- \\
=- \\
=\end{array}$ & $\begin{array}{l}40 \\
40 \\
50 \\
--\end{array}$ & $\begin{array}{l}= \\
\because- \\
= \\
=\end{array}$ & $\begin{array}{l}=- \\
=- \\
=-\end{array}$ & $\begin{array}{l}-- \\
-- \\
-- \\
-\end{array}$ & $\begin{array}{l}-- \\
-- \\
--\end{array}$ & $\begin{array}{r}-. \\
97 \\
102 \\
-- \\
--\end{array}$ & $\begin{array}{l}= \\
=- \\
=- \\
=\end{array}$ & $\begin{array}{l}=- \\
=- \\
--\end{array}$ & $\begin{array}{l}-.1 \\
.0 \\
--\end{array}$ & $\begin{array}{l}-1 \\
-0 \\
--\end{array}$ & $\begin{array}{l}-. \\
.00 \\
.00 \\
--\end{array}$ & $\begin{array}{l}-.02 \\
.07 \\
--\end{array}$ & $\begin{array}{l}.14 \\
.23 \\
-- \\
-\end{array}$ & $\begin{array}{l}-.26 \\
.28 \\
-- \\
--\end{array}$ & $\begin{array}{l}-. \\
.03 \\
.40 \\
-- \\
--\end{array}$ & $\begin{array}{l}-- \\
=- \\
m- \\
--\end{array}$ & $\begin{array}{l}= \\
\because \\
=\end{array}$ \\
\hline $\begin{array}{l}5-8-68 \\
8-20-68 \\
4-29-69\end{array}$ & $\begin{array}{l}1020 \\
0900 \\
1500\end{array}$ & $\begin{array}{r}\ddot{z} \\
7.8\end{array}$ & $\begin{array}{r}11.82 \\
8.52 \\
10.49\end{array}$ & $\begin{array}{r}108.1 \\
98.6 \\
94.9\end{array}$ & $\begin{array}{l}240 \\
230 \\
190\end{array}$ & $\begin{array}{l}11.0 \\
22.5 \\
11.1\end{array}$ & $\begin{array}{r}-- \\
2.0\end{array}$ & $\overline{29}$ & $\overline{--}$ & $\begin{array}{l}= \\
=\end{array}$ & $\overline{3.3}$ & $\because$ & $\overline{78}$ & $\overline{30}$ & $=$ & $\begin{array}{l}-- \\
-.\end{array}$ & $\overline{5.1}$ & $\begin{array}{l}-. \\
.02\end{array}$ & $\begin{array}{l}-- \\
.07\end{array}$ & $=$ & $\frac{\overline{1}}{1.33}$ & $\begin{array}{l}-. \\
-.05\end{array}$ & $\begin{array}{r}-- \\
120\end{array}$ & $\begin{array}{l}-- \\
320\end{array}$ \\
\hline
\end{tabular}


Table 31.-.-Field measurements and chemical analyses of surface samples collected routinely from stations on Oneida Lake (Continued)

(Except for ph, values represent inilligrans per liter unless otherwise indicated)

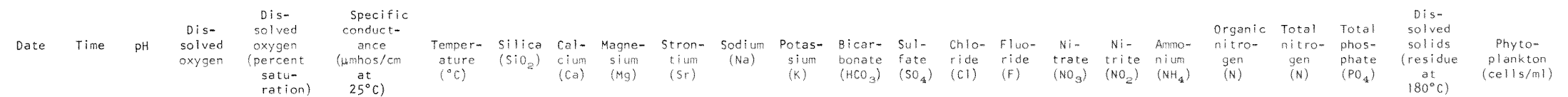

\begin{tabular}{|c|c|c|c|c|c|c|c|c|c|c|c|c|c|c|c|c|c|c|c|c|c|c|c|c|}
\hline & & & & & $\ldots$ & & & & & ONE & LAK & AMPLI & TATIOR & & & & & & & 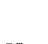 & 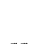 & & & \\
\hline $\begin{array}{l}5-29-67 \\
5-6-67\end{array}$ & $\begin{array}{l}1315 \\
1030\end{array}$ & $8 . \overline{4}$ & 9.50 & 100.9 & $2 \overline{2}$ & $\begin{array}{l}2.2 .2 \\
18.0\end{array}$ & 0.2 & $4 \pi$ & 9.2 & $\therefore$ & 5.2 & 0.8 & 103 & 54 & $\overline{9.4}$ & 0.2 & 0.2 & 0.01 & 0.16 & -- & -- & 0.02 & $\ddot{i i}$ & $\begin{array}{r}4,200 \\
100\end{array}$ \\
\hline $6-13-67$ & 1505 & & 7.93 & 94.5 & 285 & 24.2 & & $\ldots$ & $\ldots$ & -. & - & $\cdots$ & & -. & - & .. & -- & .. & -- & -- & -. & $\ldots$ & $\ldots$ & $<1$ \\
\hline $\begin{array}{l}6-20-67 \\
6-27-67\end{array}$ & $\begin{array}{r}0940 \\
1130\end{array}$ & 8.5 & 8.20 & $\begin{array}{r}94.5 \\
107.8\end{array}$ & $\begin{array}{l}300 \\
200\end{array}$ & 22.2 & .5 & 41 & 9.6 & $=$ & 5.4 & .8 & 104 & 54 & 9.0 & .2 & .0 & .02 & .09 & - & - & .01 & 172 & 8.740 \\
\hline $7-6-67$ & 1435 & $\ldots$ & 9.29 & 105.7 & 290 & 21.5 & 2.2 & 41 & 8.9 & $\ldots$ & 5.2 & 1.0 & 104 & 54 & 8.8 & .1 & .0 & .00 & .18 & -- & ... & .04 & 172 & $33,700+$ \\
\hline $7-10-67$ & 1055 & -- & 9.28 & 112.2 & -- & 25.0 & - & -. & - & $\cdots$ & $\cdots$ & $\cdots$ & -- & - & - & -- & $\cdots$ & $\cdots$ & -- & -- & -- & - & $\cdots$ & 23,900 \\
\hline $\begin{array}{l}7-18-67 \\
7-27-67\end{array}$ & $\begin{array}{l}1440 \\
1800\end{array}$ & -- & $\begin{array}{l}9.56 \\
9.21\end{array}$ & $\begin{array}{l}113,8 \\
11.8\end{array}$ & 305 & $\begin{array}{l}24.1 \\
25.2\end{array}$ & 0.0 & 39 & 8.8 & $=$ & 5.1 & 9.9 & $\overline{104}$ & 57 & 9.7 & .0 & .0 & .01 & .30 & 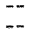 & $\because$ & .05 & 175 & $\begin{array}{r}18,500+t \\
8,500 t\end{array}$ \\
\hline $\begin{array}{l}7-2-67 \\
8-1-67\end{array}$ & 1025 & $\ldots$ & $\begin{array}{l}9.21 \\
9.56\end{array}$ & 115.4 & 30 & 24,9 & 3.0 & 29 & - & - & ... & 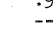 & -- & 21- & 1. & $\ldots$ & $=$ & $\therefore$ & -3 & $\ldots$ & $\ldots$ & $\ldots$ & $\ldots$ & ... \\
\hline $8-10-67$ & 0855 & -. & 8.87 & 104.4 & 290 & 23.4 & -. & $\ldots$ & $\ldots$ & $\therefore$ & - & $\cdots$ & - & -- & -- & -- & -- & $\therefore$ & -- & -- & -- & $\cdots$ & .. & $5,100+$ \\
\hline $8-17-57$ & 1255 & $9 \cdot 0$ & 9.20 & 108.4 & 310 & 23.5 & $\cdots$ & $4 ?$ & -- & -- & $\cdots$ & $\cdots$ & 96 & -- & -- & .1 & .1 & & .09 & .18 & .27 & .04 & -- & -- \\
\hline $\begin{array}{l}8-2-67 \\
3-27-67\end{array}$ & 1330 & 8.1 & $\begin{array}{l}1.45 \\
10.48\end{array}$ & $\begin{array}{l}80.0 \\
110,9\end{array}$ & 315 & 17.8 & $\ldots$ & 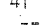 & $\ldots$ & 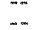 & $\because$ & $\cdots$ & $m$ & $\bar{z}$ & $\overline{--}$ & $\ldots$ & $\therefore$ & .00 & .00 & $\therefore 8$ & $\therefore$ & .49 & a & $-\infty$ \\
\hline $10-9-67$ & 1225 & $\ldots$ & 10.00 & 101.9 & -. & 16.0 & -- & -- & -. & $\ldots$ & - & -. & $\ldots$ & $\cdots$ & $\ldots$ & $\ldots$ & .. & -- & -- & -- & -- & -. & -- & -- \\
\hline $\begin{array}{l}5-8-68 \\
8-20-68\end{array}$ & $\begin{array}{l}0915 \\
1015\end{array}$ & 8.1 & $\begin{array}{r}12.03 \\
8.43\end{array}$ & $\begin{array}{r}110.1 \\
97.6\end{array}$ & 265 & $\begin{array}{l}11.0 \\
22.5\end{array}$ & .5 & 40 & $\begin{array}{r}8.5 \\
=. .\end{array}$ & .57 & 4.4 & 1.1 & 101 & 50 & 9.9 & $\begin{array}{l}.2 \\
--\end{array}$ & .0 & .03 & .00 & .02 & .03 & .04 & $\begin{array}{l}165 \\
\ldots\end{array}$ & $=$ \\
\hline & & & & & & & & & & ONE & LAK & SAMPLI & ETATIOI & 60.12 & & & & & & & & & & \\
\hline $5-29-67$ & 1345 & -- & $\cdots$ & -- & - & 12.2 & $\cdots$ & $-\cdots$ & $\cdots$ & $\cdots$ & $\cdots$ & $\ldots$ & $\cdots$ & $-\cdots$ & $\cdots$ & - & $\cdots$ & $\cdots$ & $\cdots$ & -- & -. & -. & -- & 5,100 \\
\hline $\begin{array}{l}6-6-67 \\
6-13-67\end{array}$ & 1940 & 8.4 & 9.60 & 104.9 & 290 & 19.4 & 0.2 & 42 & 9.1 & $\cdots$ & 5.1 & .8 & 104 & 56 & 9.5 & .2 & .2 & .01 & .52 & - & -- & .02 & 175 & 3,200 \\
\hline $\begin{array}{l}6-13 \\
6-20-67\end{array}$ & 1400 & 86 & 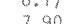 & (1) & $\begin{array}{l}2862 \\
280\end{array}$ & 22.5 & $\overrightarrow{5}$ & $47^{--}$ & 0.4 & $=$ & 52 & 8 & 104 & 54 & $a=$ & 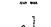 & 3 & 00 & 99 & $\ldots$ & $\ldots$ & 02 & .717 & $\begin{array}{l}18000 \\
5000\end{array}$ \\
\hline $\begin{array}{l}0-27-67 \\
6\end{array}$ & 1100 & $\cdots$ & 9.05 & 103.0 & 290 & 21.5 & $\therefore$ & -1 & 3.4 & $\ldots$ & 3.2 & $\ldots$ & $\ldots$ & - & s... & $\therefore$ & $\therefore$ & -- & 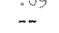 & - & $\ldots$ & $\ldots$ & $\ldots$ & $9,900+$ \\
\hline $7-6-67$ & 1400 & .- & 8.58 & 97.6 & 295 & 27.5 & 2.1 & 41 & 9.0 & $m$ & 5.1 & 1.0 & 104 & 54 & 8.9 & .1 & .0 & .12 & .17 & -. & -. & .06 & 172 & $23,300+$ \\
\hline $7-10-67$ & 1110 & & 9. & 119 & - & 25.2 & - & $\ldots$ & & $\cdots$ & .. & $\ldots$ & $\cdots$ & -1 & $\ldots$ & ... & $\cdots$ & $\ldots$ & $\cdots$ & -. & $\ldots$ & & $\cdots$ & $201,900+$ \\
\hline $7-14-67$ & 1015 & 8.3 & 7.30 & 87.3 & 310 & 24.4 & 2.0 & 41 & 9.2 & $\ldots$ & 5.0 & .9 & 102 & 54 & 9.0 & .1 & .1 & .00 & .07 & - & $\cdots$ & .07 & $17 !$ & $26,000+$ \\
\hline $7-27-67$ & $\begin{array}{l}1520 \\
1730\end{array}$ & - & $\begin{array}{l}9.00 \\
9.24\end{array}$ & $\begin{array}{l}109.1 \\
113.9\end{array}$ & 270 & $\begin{array}{l}25.1 \\
25.0\end{array}$ & 3.3 & 38 & 8.7 & $=$ & 5.0 & .9 & 104 & $56^{\circ}$ & 9.5 & .0 & .0 & .02 & .24 & $\ldots$ & $\cdots$ & .06 & 173 & $\begin{array}{l}46,1004 \\
26,5004\end{array}$ \\
\hline $8-1-67$ & 1010 & -- & 8.85 & 106.6 & -- & 24.8 & $\ldots$ & ... & -. & $\ldots . .$. & $\ldots$ & $\ldots$ & ... & $\ldots$ & .. & -. & $\ldots$ & -.. & $\ldots$ & $\ldots$ & -. & $\ldots$ & $\ldots$ & .. \\
\hline 67 & 0920 & 8.3 & 10.09 & 118.8 & 290 & $23=5$ & 2.3 & 41 & 9.1 & -- & 6.8 & 1.3 & 104 & 53 & 8.3 & .2 &.$!$ & .00 & .07 & .03 & .11 & .06 & 173 & $17,200+$ \\
\hline & 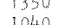 & $\begin{array}{l}8.8 \\
8.4\end{array}$ & 8.914 & 16.8 & 2300 & 2.35 & 3.2 & 40 & $\frac{1}{8.2}$ & $\cdots$ & 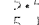 & 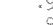 & 98 & 32 & $\begin{array}{ll}0.44 \\
88\end{array}$ & 1 & .1 & .00 & & 3 & 13 & .06 & 160 & $\begin{aligned} 20,9004 \\
3\end{aligned}$ \\
\hline $9-9-67$ & $\begin{array}{l}13400 \\
1315\end{array}$ & $\begin{array}{l}9.4 \\
7.9\end{array}$ & 8.14 & 96.7 & 310 & 24.0 & $\begin{array}{r}.8 \\
.9\end{array}$ & 43 & 10 & 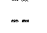 & 5.4 & 8 & 108 & 53 & $\begin{array}{l}.8 \\
9.2\end{array}$ & .1 & .3 & .00 & .00 & .03 & 10 & .33 & 137 & 3,8007 \\
\hline $9-27-67$ & 1435 & 8.6 & 10.30 & 109.4 & 285 & 18.0 & 1.9 & 4.3 & 9.4 & $\ldots$ & 5.9 & 1.8 & 107 & 54 & 9.3 & .1 & .0 & .00 & .10 & .63 & .71 & .22 & 178 & $7,000+$ \\
\hline $10-9-57$ & 1315 & 78 & 9.84 & 99.3 & 300 & 15.8 & 3 & 40 & 20 & .61 & 57 & $\therefore 0$ & 108 & $=3$ & 3.7 & 0 & $\cdots$ & $m$ & 00 & $a$ & 000 & 73 & 7 & 7,900 \\
\hline $2-27-68$ & 1145 & 7.4 & 14.60 & 101.2 & 260 & 0 & 3.9 & 33 & 8.5 & .38 & 5.7 & 1.0 & 92 & 37 & 9.8 & .0 & 1.5 & .00 & .37 & .07 & .70 & .03 & 145 & $<1$ \\
\hline $4-18-68$ & 0930 & 7.6 & -. & -- & 265 & 8.2 & 1.9 & 38 & 7.4 & .48 & 4.3 & 1.0 & 96 & 46 & 9.8 &.$i$ & .6 & .00 & .00 & & .32 & .05 & 274 & $m$ \\
\hline $5-8-68$ & 1150 & 8.1 & 12,25 & 111.9 & 265 & 10.9 & .6 & 39 & 8.3 & .53 & 4.3 & 3.0 & 97 & -7 & 9.0 & .2 & .2 & .03 & .00 & .14 & .19 & .00 & 158 & 2,300 \\
\hline $\begin{array}{l}-8-14-68 \\
6-14=88\end{array}$ & $\begin{array}{l}0945 \\
0950\end{array}$ & 7.9 & 10. & 112.2 & 275 & $\begin{array}{l}1.5 \\
18.6\end{array}$ & 1.0 & 38 & 8.5 & . & 4. & 1.8 & 99 & 499 & 9.0 & 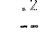 & .5 & .01 & $\ldots$ & 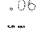 & 28 & .20 & $\begin{array}{l}162 \\
\ldots . .\end{array}$ & $\begin{array}{l}500 \\
100\end{array}$ \\
\hline $7-2-68$ & 0730 & -. & 8.20 & 90.7 & 260 & 20.0 & 2.8 & 38 & 8.4 & .52 & 4. & 1.0 & 100 & 48 & 9.1 & .0 & .2 & .00 & .06 & .17 & .26 & .20 & 162 & 7,700 \\
\hline $7=10-68$ & 0730 & - & 9.22 & 105.8 & 260 & 22.0 & -- & & & -- & - & $\ldots$ & $\ldots$ & m- & - & m & $m$ & $\ldots$ & $\ldots$ & $\ldots$ & $\cdots$ & -- & $\ldots$ & 850 \\
\hline
\end{tabular}




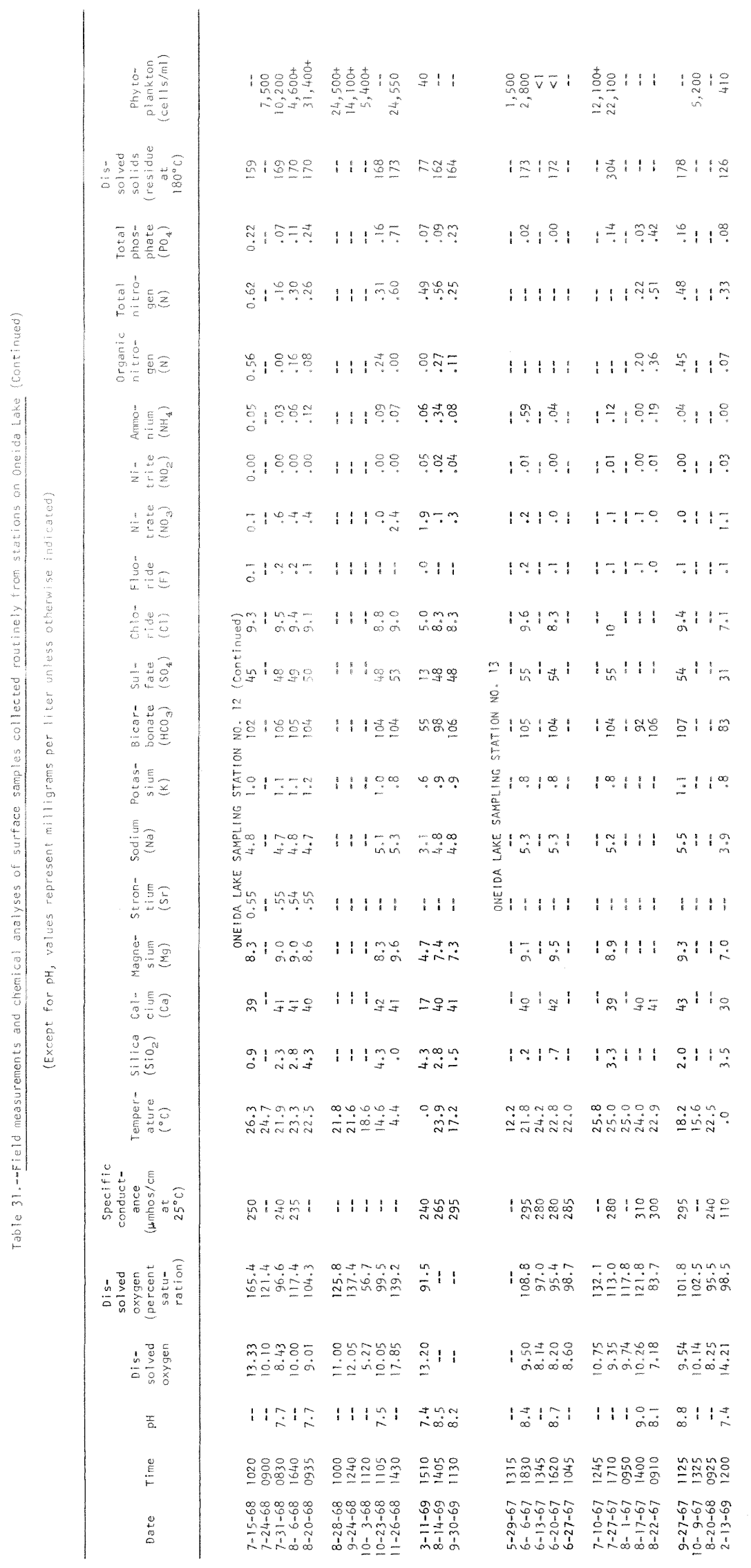




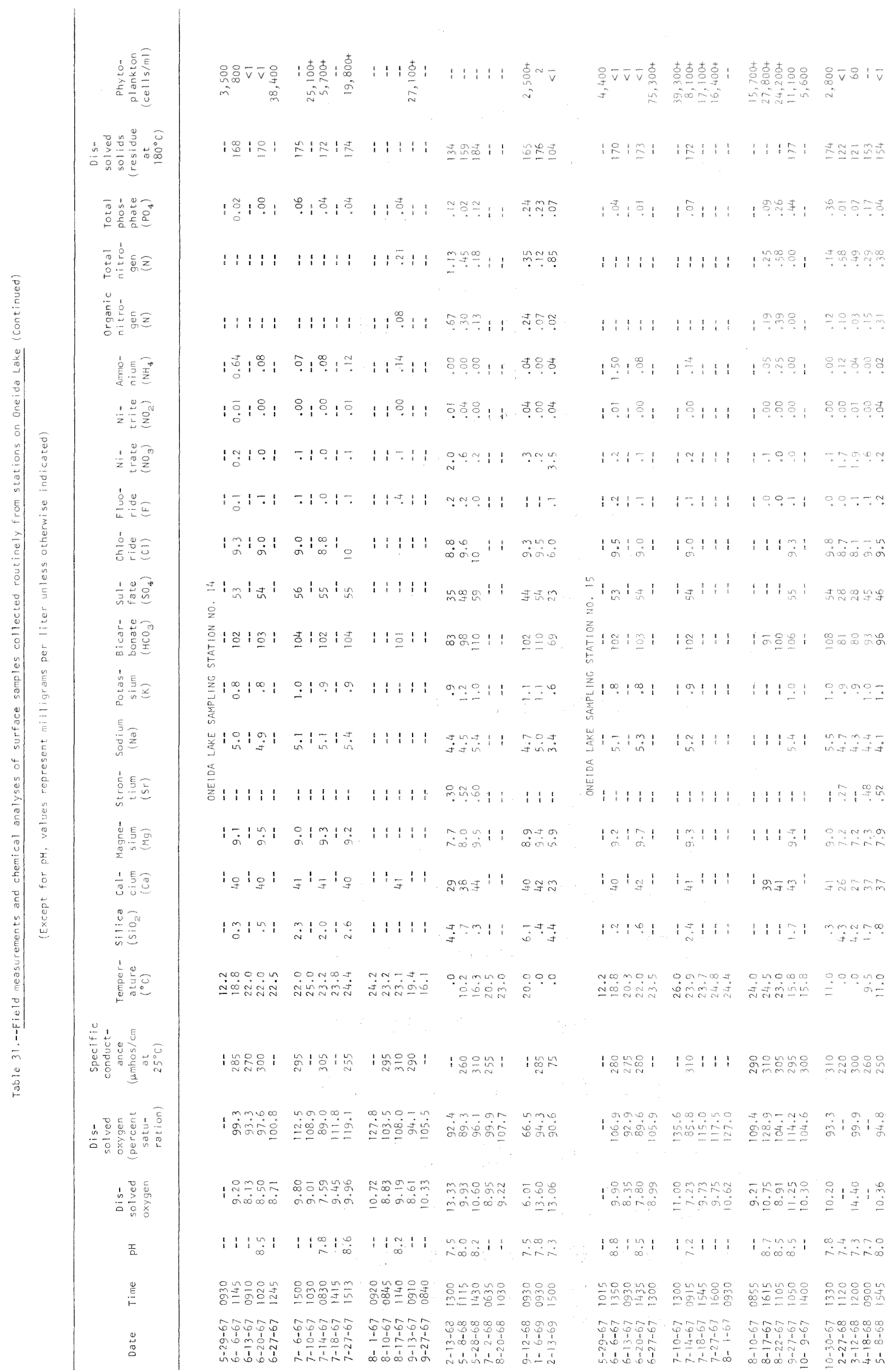




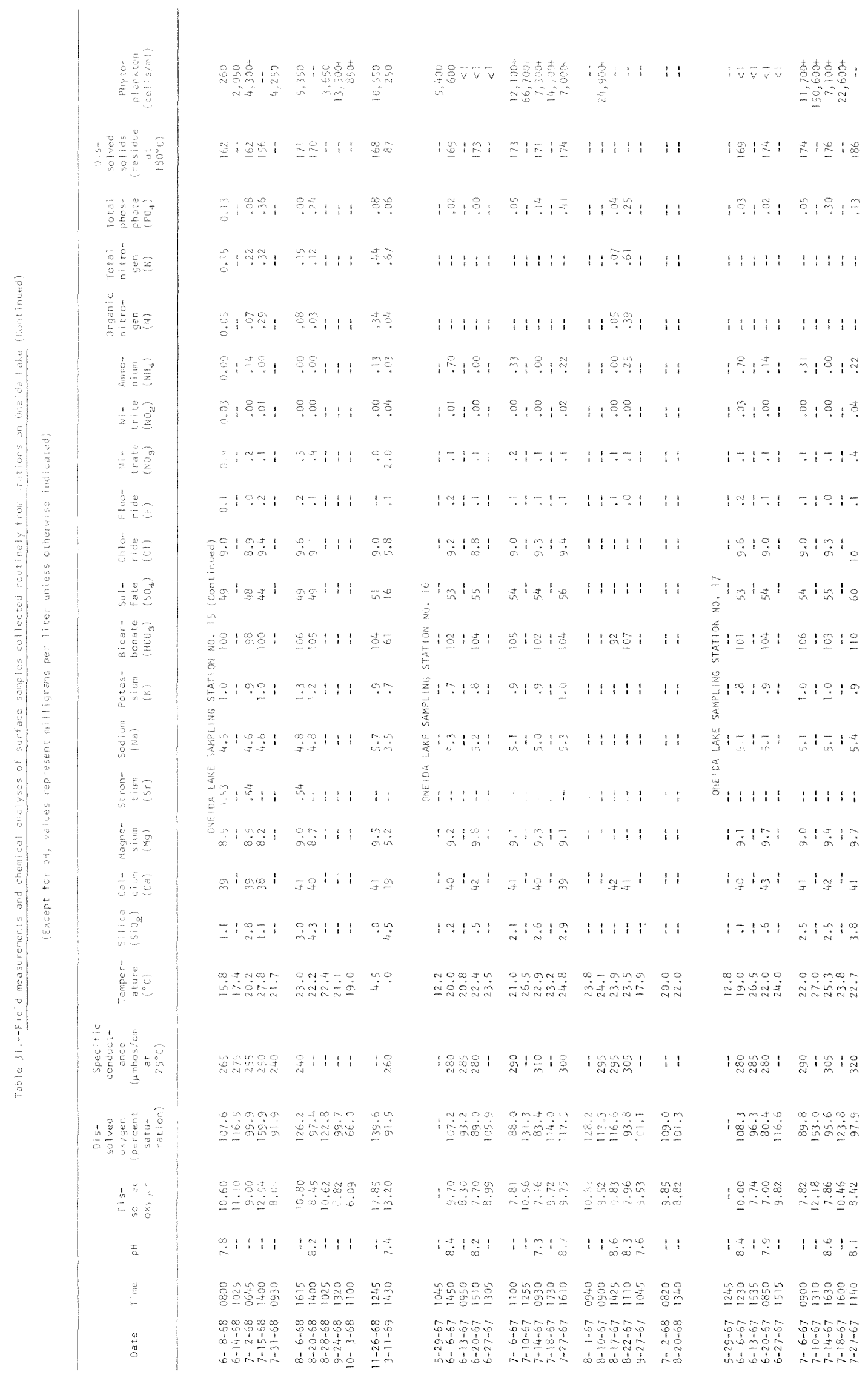




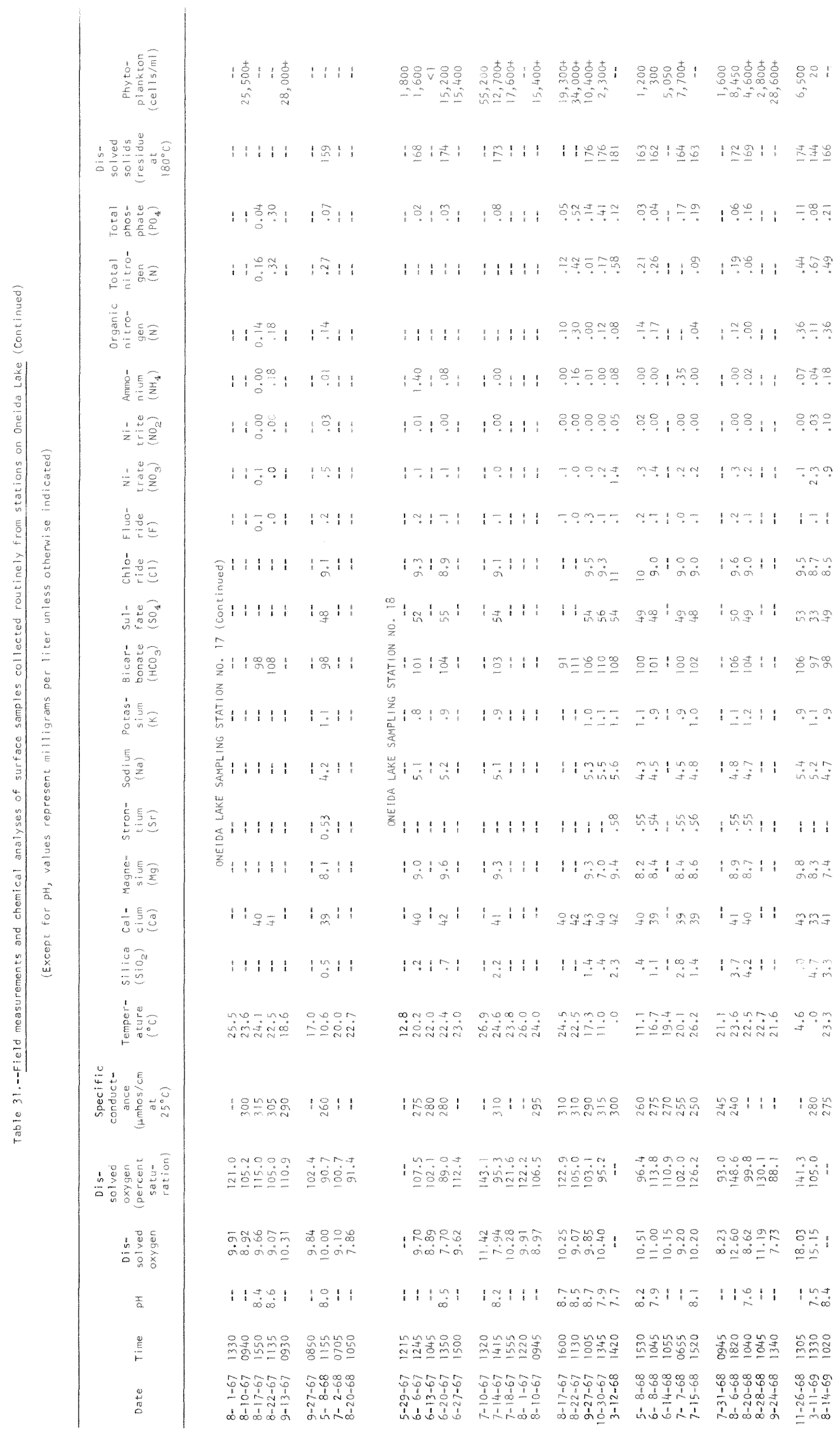


Table 31.-.-Field measurements and chemical anolyses of surface samples collected rontinely from stotions on aneida take (Continued)

(Except for pH, values represent milligrans per lifter unless otherwise indigated

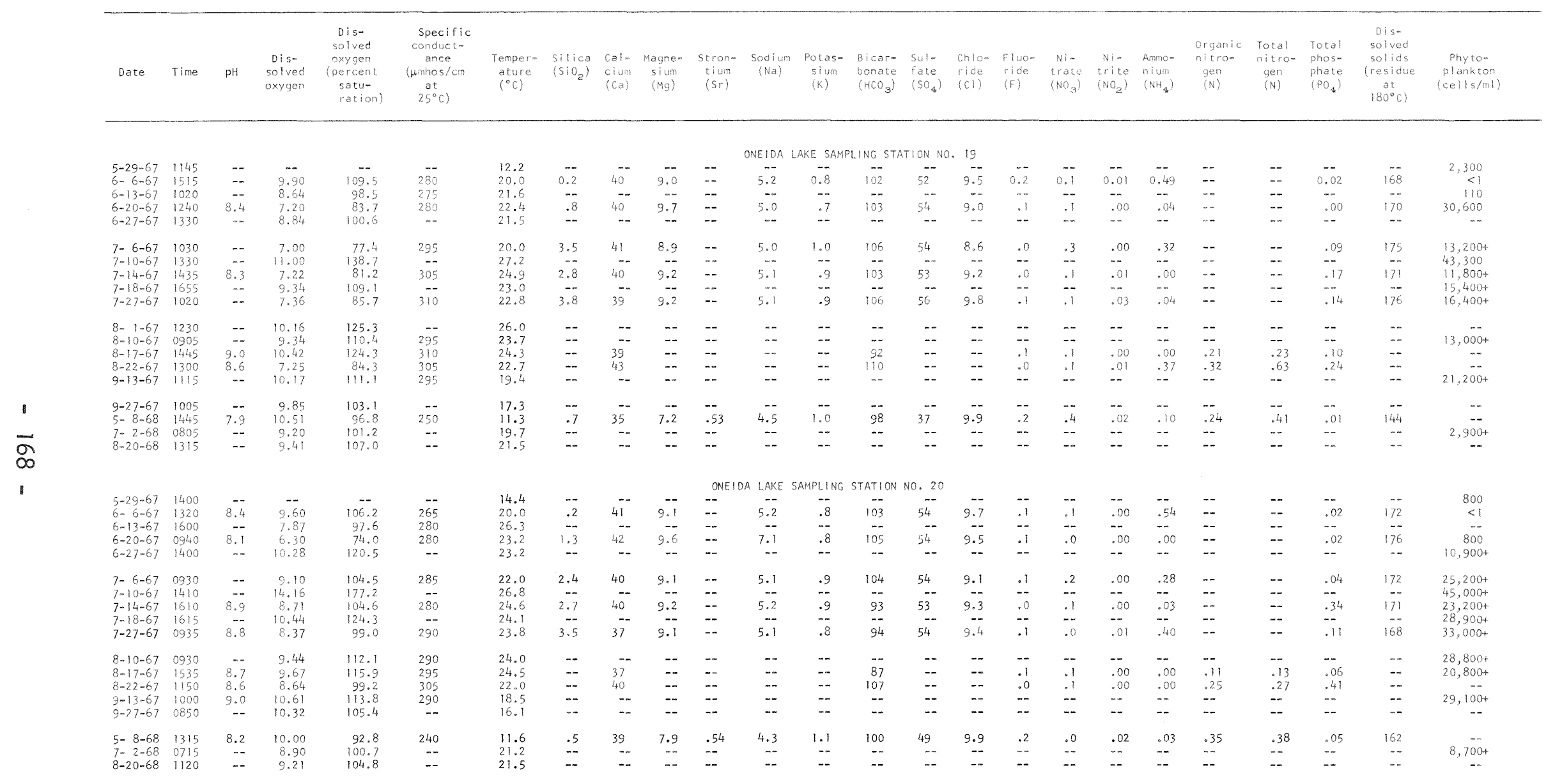




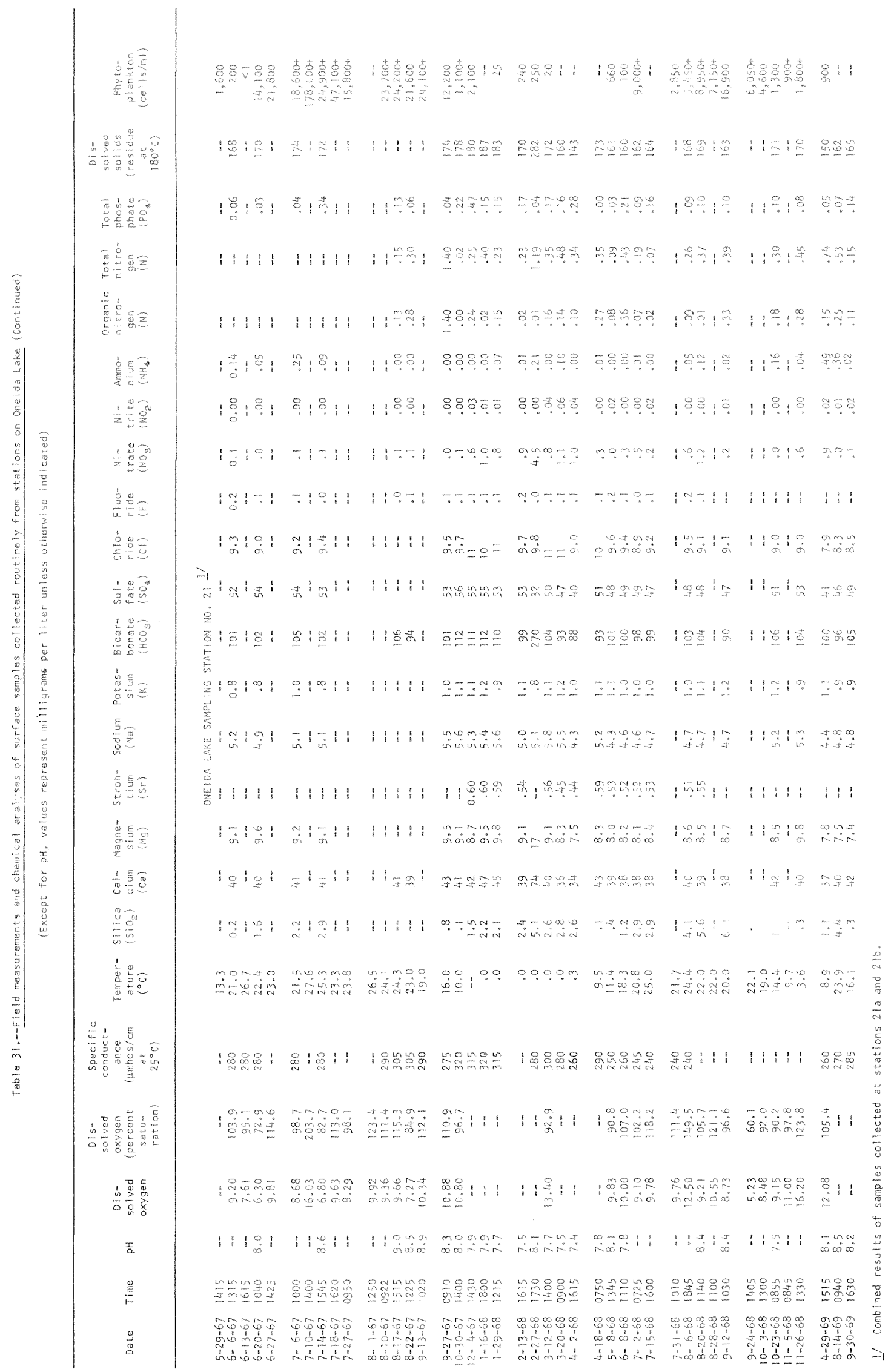




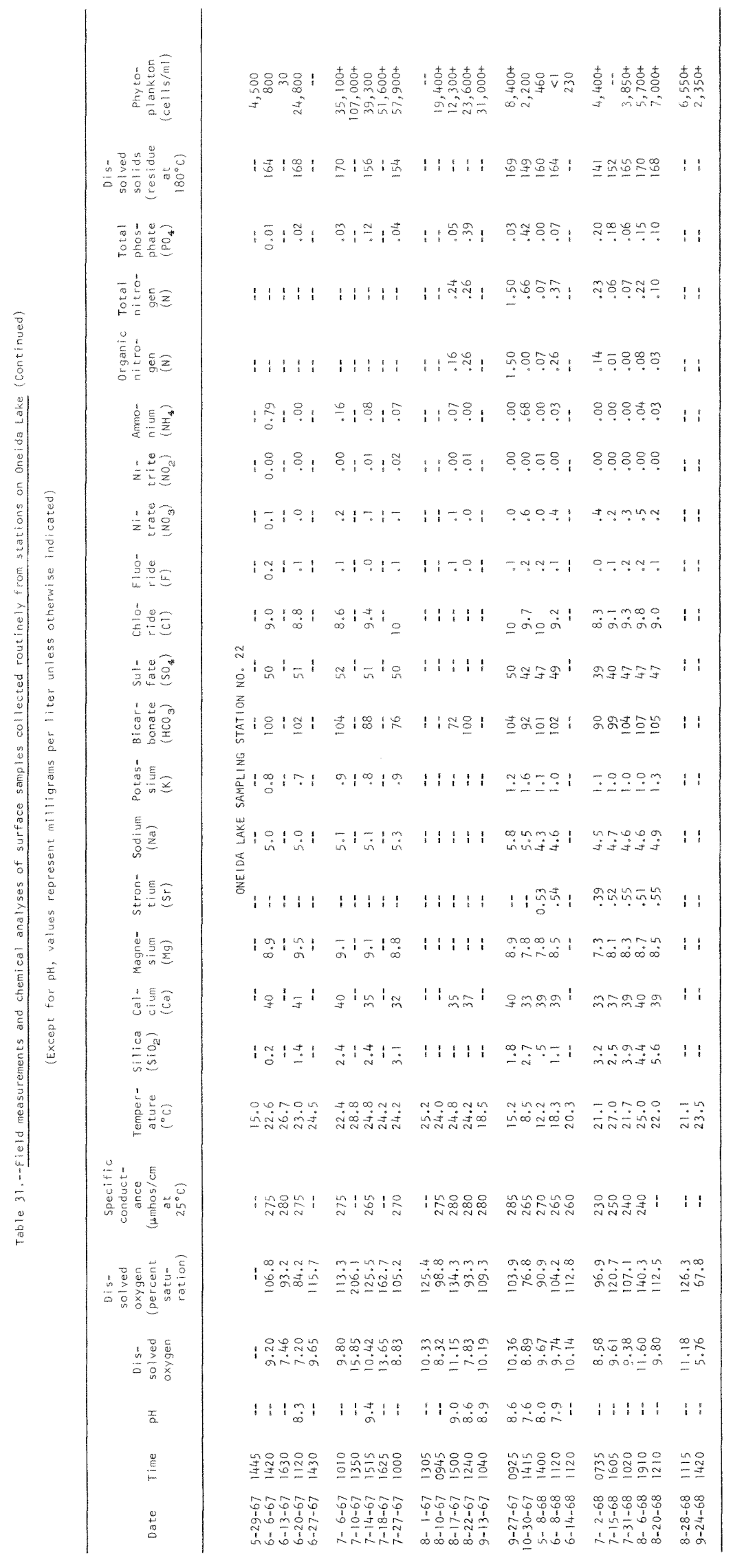


Table 32.--Checklist of the flora and the fauna of Oneida Lake
A. Algae (other than phytoplankton). B. Fish.
C. Macroinvertebrates. D. Vascular Plants.
E. Zooplankton

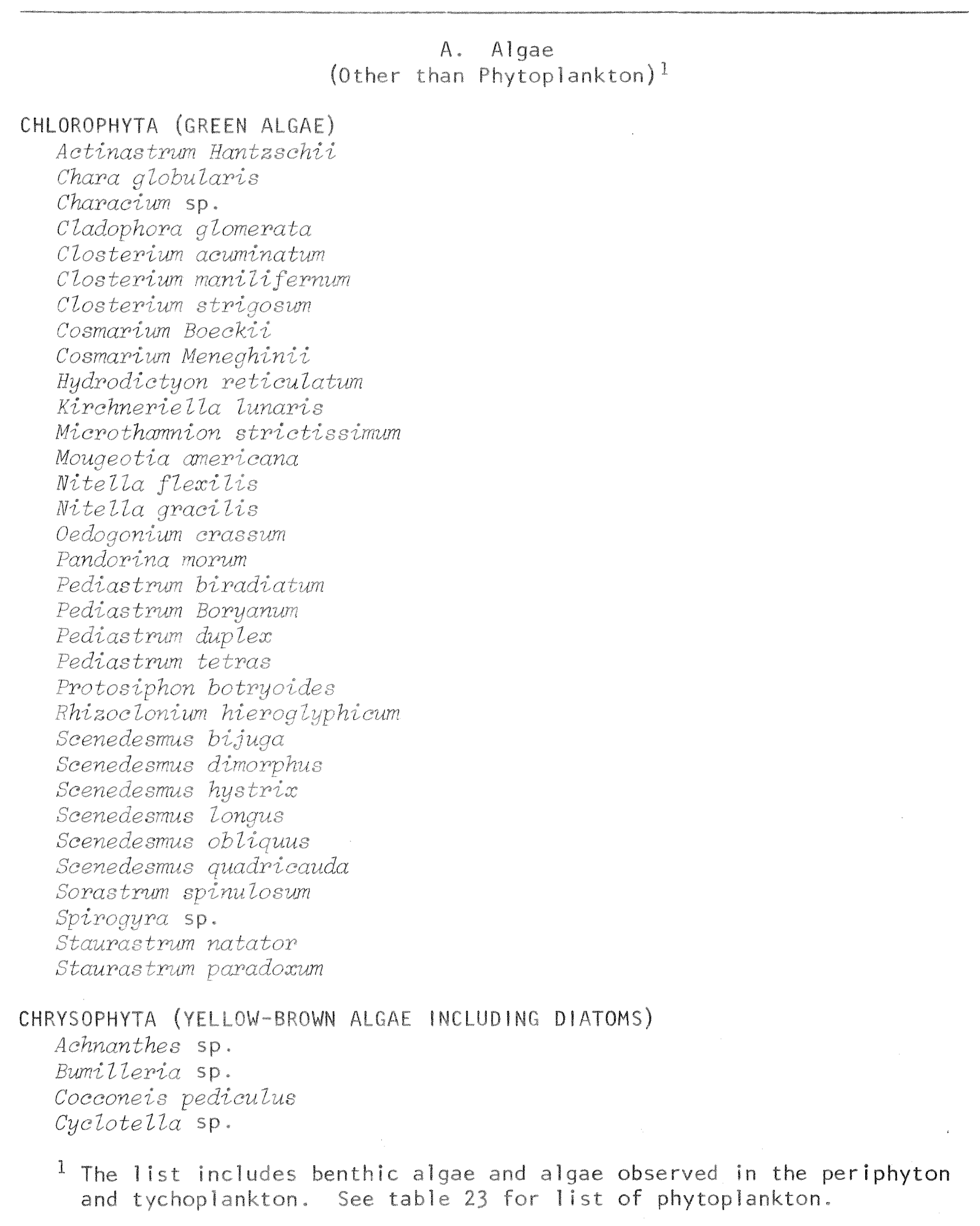


Table 32.--Checklist of the flora and the fauna of Oneida Lake--Continued

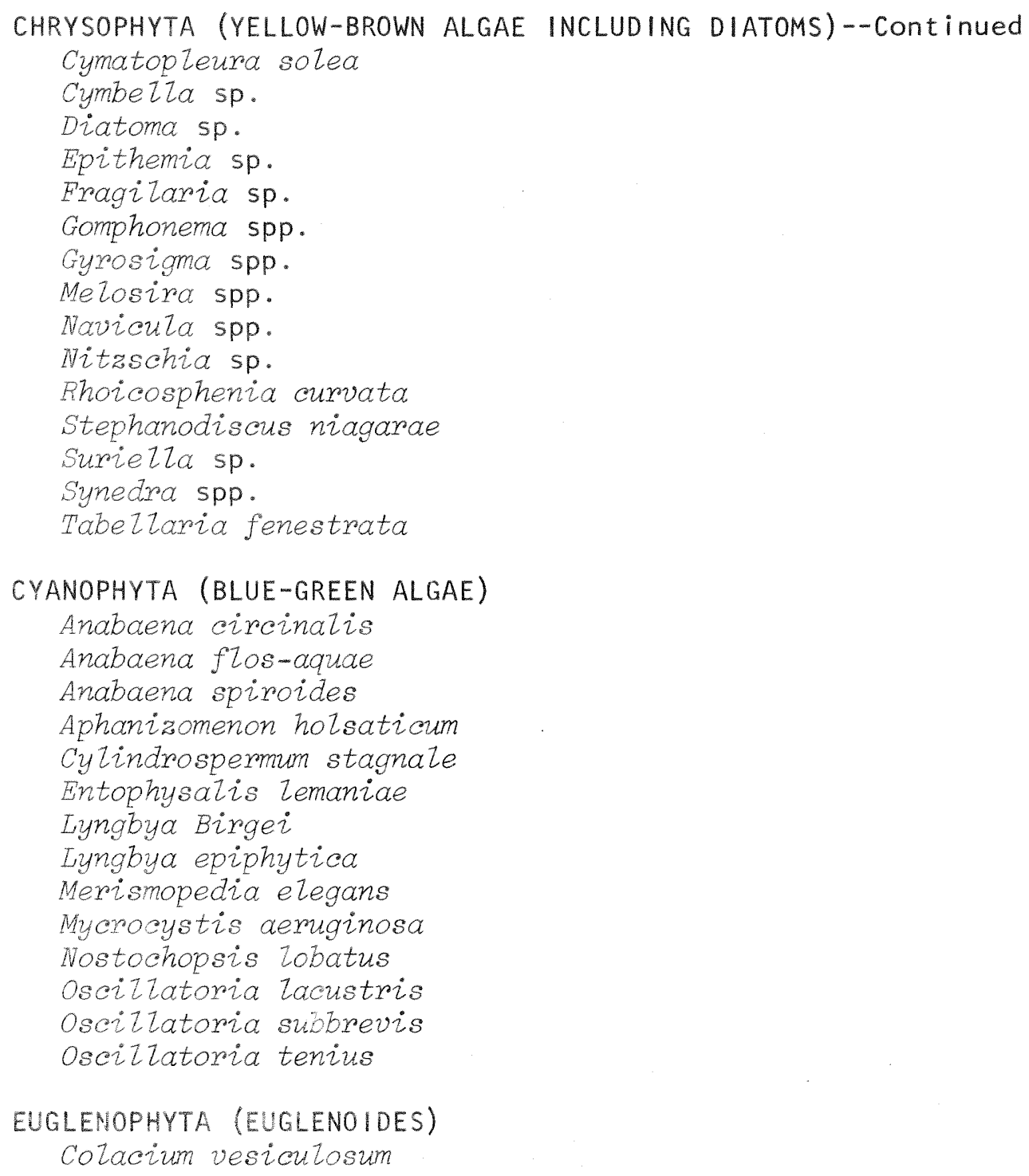


Table 32.-- Checklist of the flora and the fauna of Oneida Lake---Continued

\section{B. FISH}

ACIPENSERIDAE (STURGEON FAMILY)

Acipenser futvescens, Lake Sturgeon

AMIIDAE (BOWFIN FAMILY)

Amia catva, Bowfin

ANGUILLIDAE (FRESHWATER EEL FAMILY)

Anquilta rostrata, American Eel

ANTHERINIDAE (SILVERSIDES FAMILY)

Labidesthes sicculus, Brook Silverside

CATOSTOMIDAE (SUCKER FAMILY)

Catostomus commersoni, White Sucker

Erimyzon obzongus, creek Chubsucker

Eximyzon succetta, Lake Chubsucker

Hypentelium nigricans, Hogsucker

Moxostoma aureolum, Northern Redhorse

CENTRARCHIDAE (SUNFISH FAMILY)

Ambloplites mpestris, Rock Bass

Lepomis cyaneztus, Green Sunfish

Lepomis gibbosus, Pumpkinseed

Lepomis macrochimus, Bluegill

Lepomis megalotis, Longear Sunfish

Micropteme dolomieui, Smallmouth Bass

Microptems salmoides, Largemouth Bass

Pomoxis annularis, White Crapple

Pomoxis nigromaculatus, Black Crappie

CLUPEIDAE (HERRING FAMILY)

Also pseudohorengus, Alewife

Dorosoma cepedianum, Gizzard Shad

COTTIDAE (SCULPIN FAMILY)

Cottus bairdi, Northern Sculpin

CYPRINIDAE (MINNOW FAMILY)

Cyprinus carpio, European Carp

Exoglossum maxilzingua, Cutlip Minnow

Hybognathus muchatis, Silvery Minnow

Notemigonus crysoleucas, Golden Shiner

Notropis atheminoides, Emerald Shiner

Notropis bifrenatus, Bridled Shiner

Notropis cayuga, Cayuga Minnow

Notropis comutus, Common Shiner

Notropis deliciosus, Sand shiner

Notropis dorsalis, Bigmouth Shiner

Notropis heterolepis, Blacknose Shiner 
Table 32.--Checklist of the flora and the fauna of Oneida Lake--Continued

CYPRINIDAE (MINNOW FAMILY) --Continued Notropis hudsonius, Spottail Minnow Notropis mbelzus, Rosyface Shiner Notropis whippli, Steelcolor Shiner Pimephales notatus, Bluntnose Minnow Rhinichthys atratulus, Blacknose Dace Rhinichthys cataractae, Longnose Dace Semotilus atromacutatus, Creek Chub Semotitus corporatis, Fallfish

CYPRINODONTIDAE (KILLIFISH FAMILY) Fundulus diaphanus, Banded Killifish

ESOCIDAE (PIKE FAMILY)

ESOx Lucius, Northern Pike

Esox masquinongy, Muskellunge

Esox niger, chain Pickerel

GADIDAE (COD FAMILY)

Lota Lota, Freshwater Burbot

GASTEROSTEIDAE (STICKLEBACK FAMILY)

Eucatia inconstans, Brook Stickleback

HIODONTIDAE (MOONEYE FAMILY)

Hiodon tergisus, Mooneye

ICTALURIDAE (CATFISH FAMILY)

Ictalume natatis, Yellow Bull head

Ictalums nebulosus, Brown Bullhead

Ictalums punctatus, Channel Catfish

Notums flavus, Stonecat

Notums gyrinus, Madtom

Noturus miurus, Madtom

LEPISOSTEIDAE (GAR FAMILY)

Lepisosteus osseus, Longnose Gar

PERCIDAE (PERCH FAMILY)

Etheostoma exile, lowa Darter

Etheostoma flabeZlare, Fantail Darter

Etheostoma nigrum, Johnny Darter

Perca flavescens, Yellow Perch

Percina caprodes, Log Perch

Percina maculata, Blackside Darter

Stizostedion vitreum, Pikeperch or Walleye

PERCOPSIDAE (TROUTPERCH FAMILY)

Percopsis omiscomaycus, Eastern Troutperch 
Table 32.--Checklist of the flora and the fauna of Oneida Lake--Continued

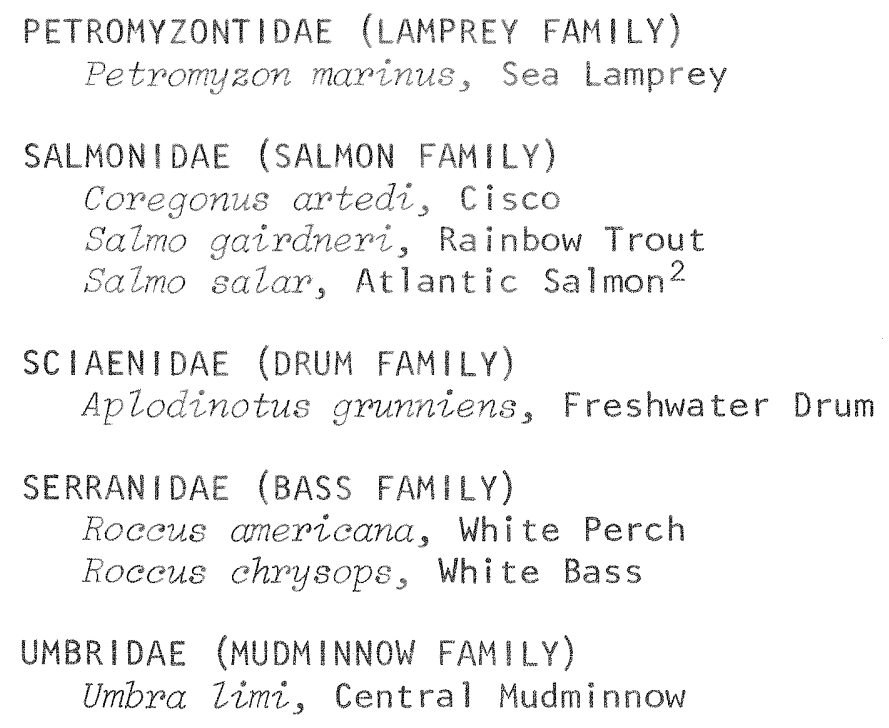

2 Atlantic salmon at one time were very abundant in oneida Lake but the fish have not been observed in the lake for almost one hundred years. 
Table 32.--checklist of the flora and the fauna of Oneida Lake--continued

\section{MACROINUERTEBRATES}

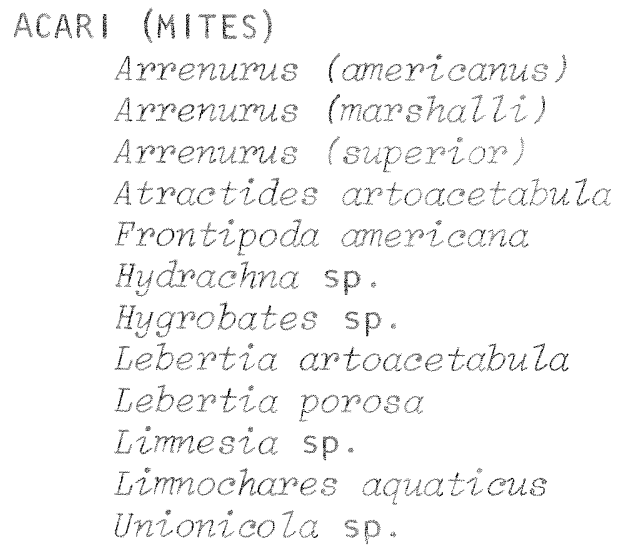

\section{AMPHIPODA}

Gommanus fasciatus

Gammarus Zacustris

Hyatella azteca (H. kniokerbockeri)

\section{BRYOZOA}

Plumatelia sp.

\section{COELENTERATA}

Hydra oligactis

\section{DECAPODA (CRAYFISHES)}

Combams bontonii

Combarus sp.

\section{HIRUNDINEA (LEECHES)}

Batrachobdelta phatera

Batrachobdella pioto

Glossiphonia complanata

Hoemopis grandis

Haemopis marmorata

Helobdelza fusca

Pisicola sp.

Placobdella montifera

Placobdelza ornata

Placobdetla parasitica

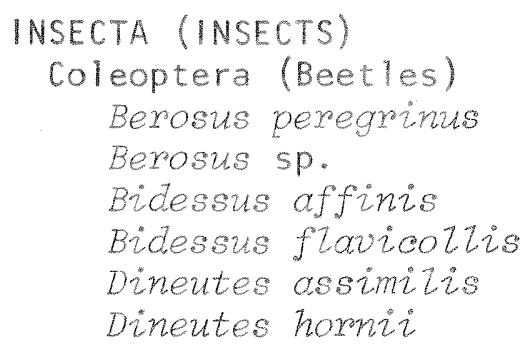


Table 32.--Checklist of the flora and the fauna of Oneida Lake--Continued

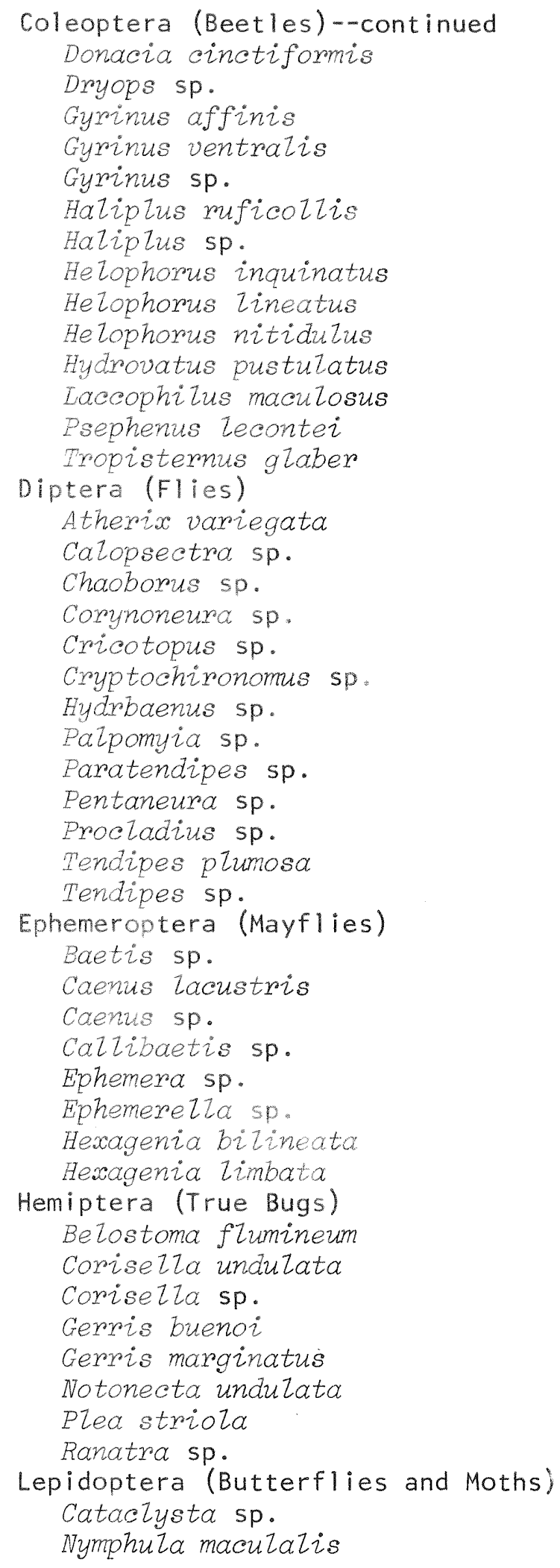


Table 32. - Checklist of the flora and the fauna of Oneida Lake--Cont inued

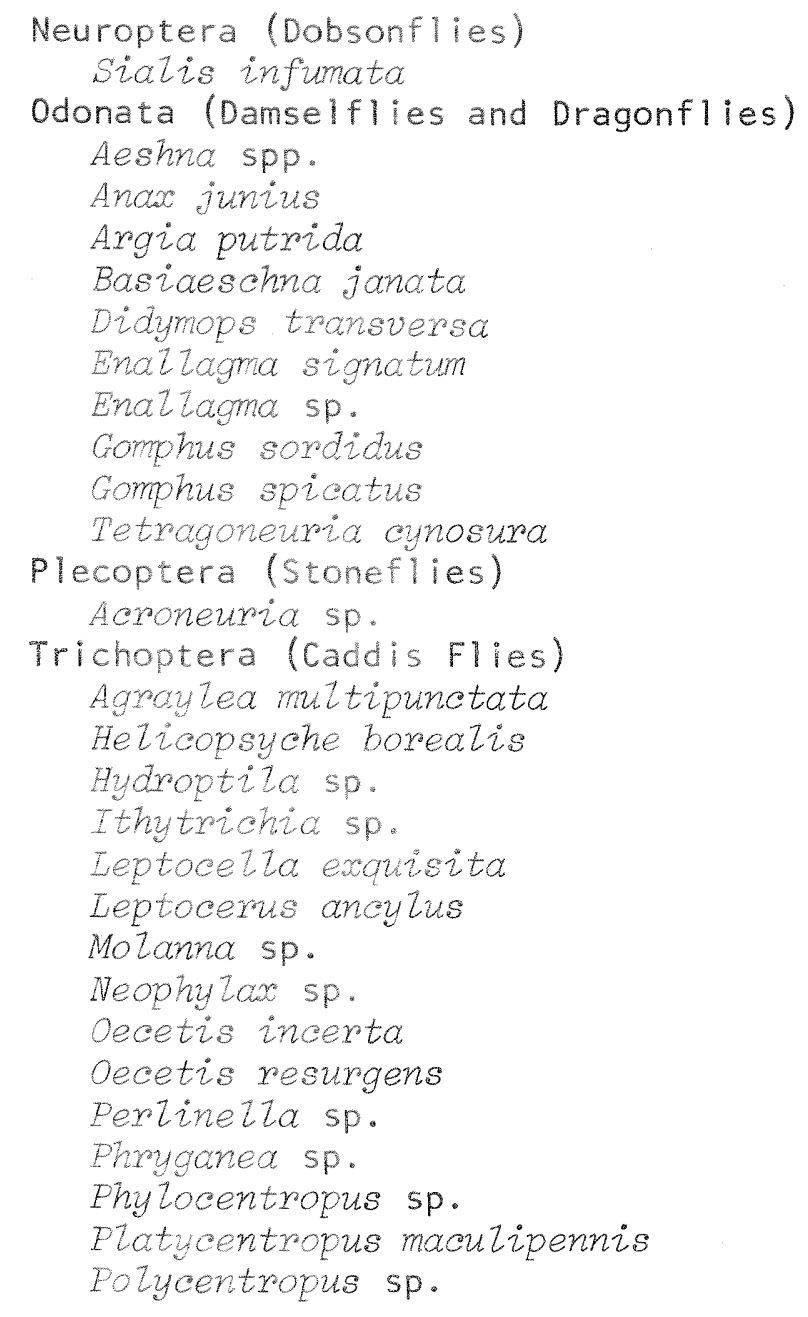

\section{ISOPODA}

Ascellus communis Ascellus sp.

Iirceus sp.

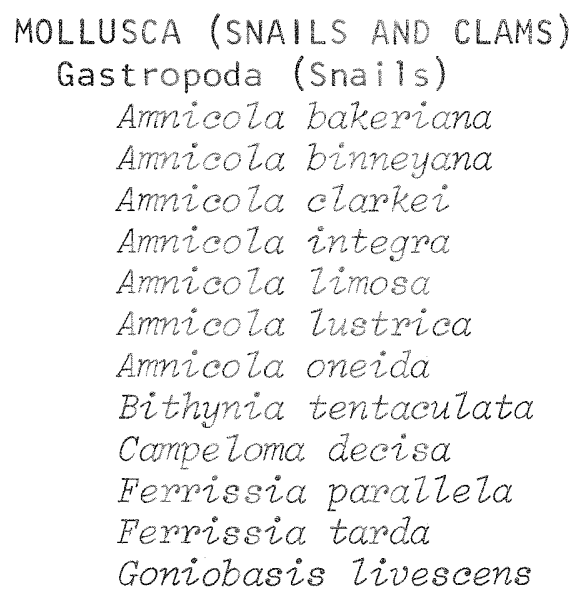


Table 32.--Checklist of the flora and the fauna of Oneida Lake--Continued

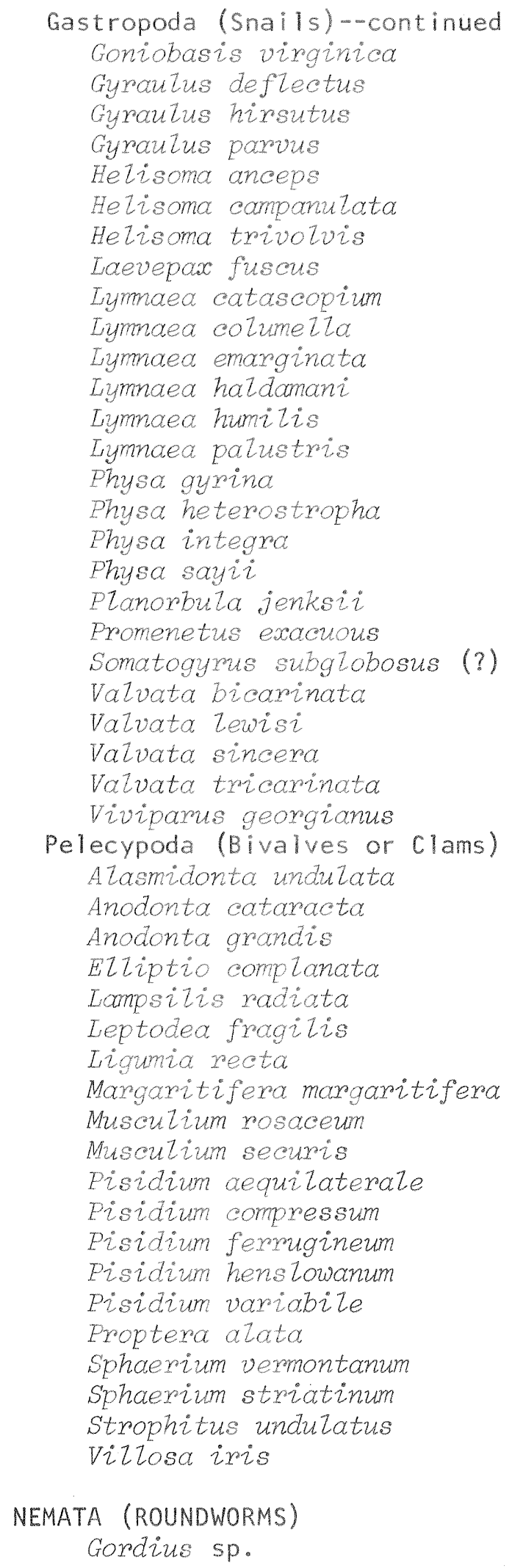


Table 32.--Checklist of the flora and the fauna of Oneida Lake--Continued

OLIGOCHAETA (SEGMENTED WORMS)

Dero digitata (D. Zimosa)

Nais sp.

Pristina sp.

PORIFERA (SPONGES)

Carterius tubispermus

Heteromeyenia sp.

Spongizla fragizis

Spongizla heterosclerifera

Spongizla Zacustris

TURBELLARIA

Dugesia dorotocephala

Dugesia tigrina 
Table 32.--Checklist of the flora and the fauna of Oneida Lake--Continued

D. VASCULAR PLANTS

ACANTHACEAE (WATER WILLOW FAMILY)

Justicia americana (Dianthera americana)

ALISMACEAE (WATER PLANTAIN FAMILY)

Alisma gramineum

Alisma Plantago-aquatica (A. triviale)

Sagittaria cuneata (S. arifolia)

Sagittaria EngeImaniana

Sagittaria Zatifolia

Sagittaria rigida

ARACEAE (ARUM FAMILY)

Acomus Catamus

Peltandra virginica

ASCLEPIADACEAE (MILKWEED FAMILY)

Asclepias incarnata

CERATOPHYLLACEAE (HORNWORT FAMILY)

Ceratophyztum demersum

COMPOSITAE (COMPOSITE FAMILY)

Bidens discoided

Bidens frondosa

Eupatorium maculatum

Eupatorium perfoliatum

Helenium autrunate

Solidago graminifloria

CRUCIFERAE (CRESS FAMILY)

Rorippa sylvestris

CYPERACEAE (SEDGE FAMILY)

Carex hystericina

Carex Zanuginosa

Carex Zasiocarpa

Carex stipata

Carex vulpinoidea

Cyperus esculentus

Cypems strigoous

Eteocharis acicutaris

Eleocharis calva

Eleocharis compressa

Eleocharis obtusa

Eleocharis pauciflora

Scirpus acutus (S. occidentalis)

Scirpus americanus

Scirpus atrovirens

Scirpus fluviatitis 
Table 32.--Checklist of the flora and the fauna of Oneida Lake--Continued

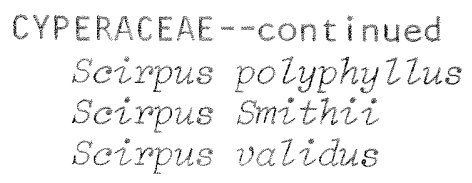


Table 32.-- checklist of the flora and the fauna of Oneida Lake-- Continued

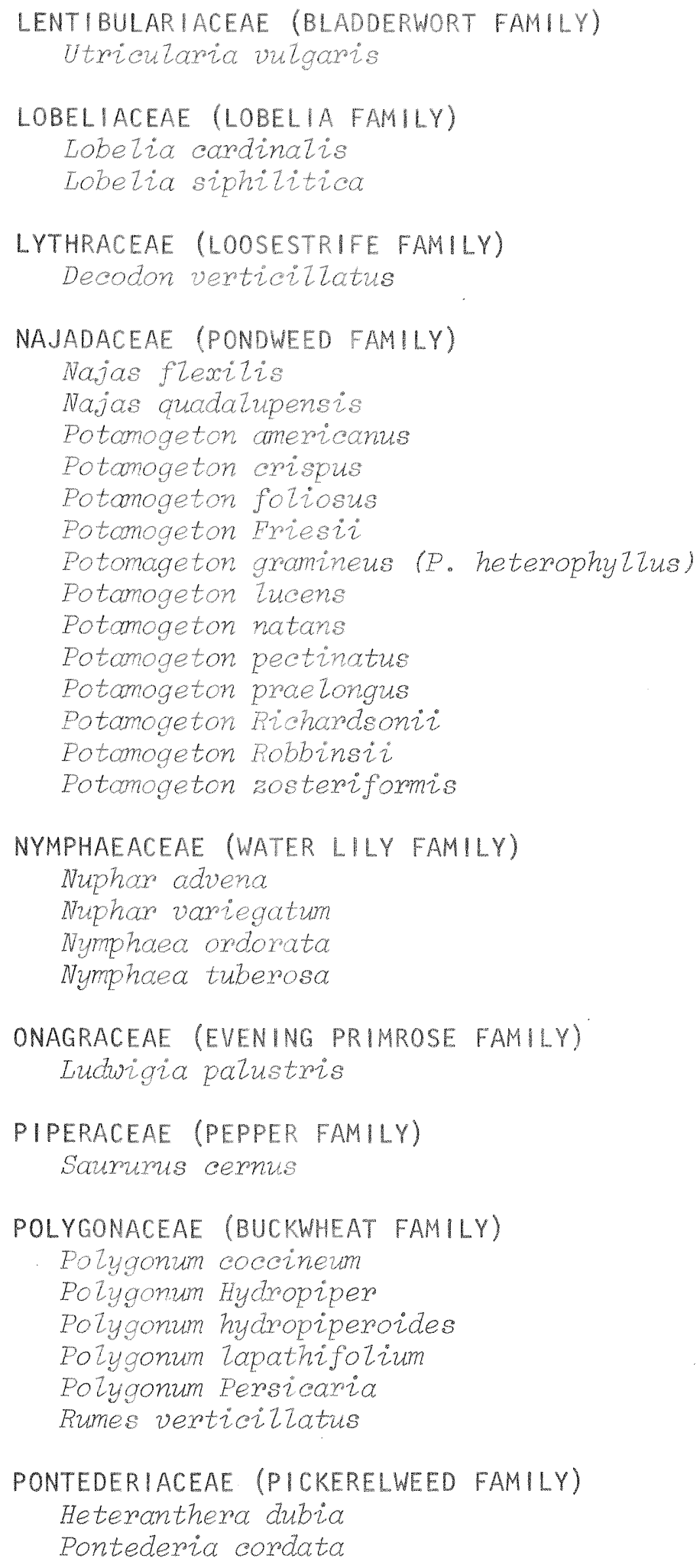


Table 32.--Checklist of the flora and the fauna of Oneida Lake--Continued

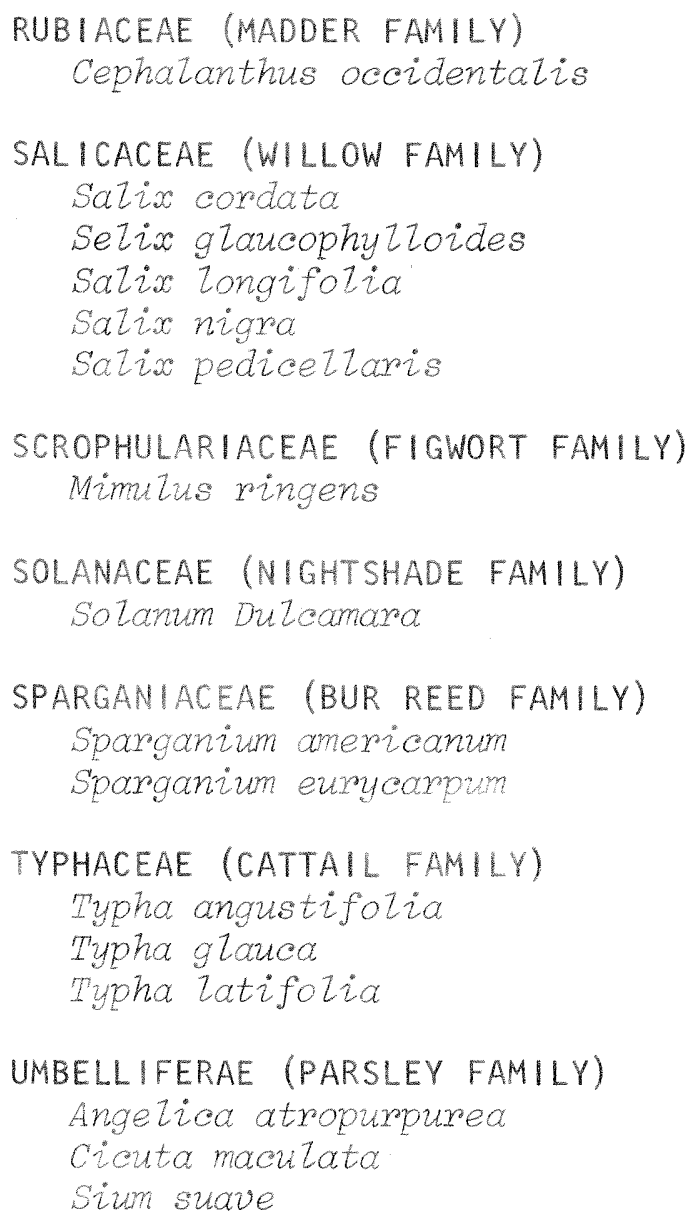


Table 32.--Checklist of the flora and the fauna of Oneida Lake--Continued

\section{E. ZOOPLANKTON}

\section{PROTOZOA}

Difflugia lebes

Vorticelta sp.

\section{ROTIFERA}

Asp Ianchna sp.

Kellicotia Longispina

Kerateita cochlearis

\section{CRUSTACEA}

AZona sp.

Bosmina Longirostris

Ceriodaphnia quadrangulata

Chydomis sphaemans

Cyclops bicuspidatus thomasi

Cyctops vernatis

Daphnia galeata mendotae

Dophnia retrocuma

Daphnia pulex

Diaphanosoma Zeuchtenbergianum

Diaptomus minutus

Diaptomus oregonensis

Diaptomus sicitis

Epischura Lacustris

Ergasizus chautauguaensis

Eucyclops agilis

Eurycerus Zomelzatus

Leptodora kindtiz

Mesocyclops edax

Mysis relicta

Sida crystallina

Tropocyclops prasinus

ACARI

Hydracarina sp. 